\title{
Negotiating Power: Gender and Body Politics in the New Wave Japanese Cinema
}

\author{
by
}

Bianca Otilia Briciu

A thesis submitted to the Faculty of Graduate and Postdoctoral Affairs in partial fulfillment of the requirements for the degree of

Doctor of Philosophy

in

Cultural Mediations

Carleton University

Ottawa, Ontario

(C) 2012, Bianca Otilia Briciu 
Library and Archives

Canada

Published Heritage

Branch

395 Wellington Street

Ottawa ON K1A ON4

Canada
Bibliothèque et

Archives Canada

Direction du

Patrimoine de l'édition

395 , rue Wellington

Ottawa ON K1A ON4

Canada
Your file Votre référence

ISBN: $978-0-494-94211-6$

Our file Notre référence

ISBN: $978-0-494-94211-6$
NOTICE:

The author has granted a nonexclusive license allowing Library and Archives Canada to reproduce, publish, archive, preserve, conserve, communicate to the public by telecommunication or on the Internet, loan, distrbute and sell theses worldwide, for commercial or noncommercial purposes, in microform, paper, electronic and/or any other formats.

The author retains copyright ownership and moral rights in this thesis. Neither the thesis nor substantial extracts from it may be printed or otherwise reproduced without the author's permission.
AVIS:

L'auteur a accordé une licence non exclusive permettant à la Bibliothèque et Archives Canada de reproduire, publier, archiver, sauvegarder, conserver, transmettre au public par télécommunication ou par l'Internet, prêter, distribuer et vendre des thèses partout dans le monde, à des fins commerciales ou autres, sur support microforme, papier, électronique et/ou autres formats.

L'auteur conserve la propriété du droit d'auteur et des droits moraux qui protege cette thèse. $\mathrm{Ni}$ la thèse ni des extraits substantiels de celle-ci ne doivent être imprimés ou autrement reproduits sans son autorisation.
In compliance with the Canadian Privacy Act some supporting forms may have been removed from this thesis.

While these forms may be included in the document page count, their removal does not represent any loss of content from the thesis.
Conformément à la loi canadienne sur la protection de la vie privée, quelques formulaires secondaires ont été enlevés de cette thèse.

Bien que ces formulaires aient inclus dans la pagination, il n'y aura aucun contenu manquant. 


\begin{abstract}
I analyze in this dissertation films about women made by Imamura Shōhei, Yoshida Kiju and Hani Susumu, three representative figures of the New Wave Japanese cinema, arguing that these films make visible gender and body politics in postwar Japan. They explore the cultural construction of female bodies through the representation of the body as an interface between individual subjectivity and cultural norms, politicizing both sexuality and the medium of cinema. In my analysis of the films I will outline the duality between the look and the gaze and I will demonstrate that these filmmakers construct an ethical form of representation that recognizes the alterity of women. My analysis is informed by phenomenological theories that explore bodies as interconnected ways of being in the world and a feminist analysis of power concerned with the disciplining of female bodies.
\end{abstract}

The main argument of the dissertation is that these three directors perform a negotiation of gender power inherent in the institution of cinema through a selfreflexive cinematic style that critiques the power of the male gaze. Imamura, Yoshida and Hani regard cinema as a mode of intersubjective engagement with the world based on an ethical negotiation of gender power. Their ethical position involves an encounter with female alterity that disrupts the filmmaker's illusory position of omnipotence or the power of the gaze as a gendered mechanism of oppression. The representation of the female body involves both desire and responsibility, a duality inherent in their films as the interlacing of the gaze with the look. This duality makes it possible for the three filmmakers to explore female bodies not only as objects of male desire, but also as the foundations of female subjectivity. The films represent women's version of the body as political struggle against repressive ideological forces 
of society, in contrast to the dominant postwar male discourse of the body as source of pleasure and liberation.

My case studies will be Imamura's two fiction films: Insect Woman (1963) and Intentions of Murder (1964), Imamura's two documentaries: The History of Postwar Japan as Told by a Bar Hostess (1970) and Karayuki-san, the Making of a Prostitute (1973), Yoshida's Eros Plus Massacre (1969) and Hani's Nanami, the Inferno of First Love (1968). 


\section{Acknowledgements}

I would like to thank my husband, Constantin Rusan, for his invaluable technical and emotional support as well as my children, Maya and Andrew, for teaching me the paradoxical lesson that less (time) means more (focus).

I would like to thank my advisor, Mitsuyo Wada-Marciano for her detailed reviews and for her continuous support during these years.

Special thanks to the Social Sciences Research Council for four years of financial support that made possible this research. 
Table of Contents

Introduction.

Chapter One. Bodies as Subjects and Objects-An Interdisciplinary

Consideration of Gendered Bodies in Cinema

Chapter Two. Rituals of Disciplining the Female Body: Prostitution and Rape in Imamura Shōhei's Insect Woman (Nippon konchüki, 1963) and Intentions of Murder (Akai satsui, 1964)

Chapter Three. The Female Body as Boundary of the Nation: Embodying the Postwar in Imamura Shōhei's Documentaries: The History of Postwar Japan as Told by a Bar Hostess (Nippon sengoshi, madamu Onboro no seikatsu 1970) and Karayuki san, The Making of a Prostitute (Karayuki-san, 1973) ........................... 104

Chapter Four. Bodies in Time: The Politics of Love, Sex and Freedom in Yoshida Kiju's Eros + Massacre (Erosu +gyakusatsu, 1969).

Chapter Five. Love and Power, The Appropriation of the Adolescent Body in Hani Susumu's Nanami, Inferno of First Love (Nanami, hatsukoi jigokuhen, 1968)

Conclusion 210 


\section{Introduction}

Many scholars have shown how the dramatic social and political transformations in Japan, the collapse of imperialist regime, loss of war, Occupation, and political protests in the 1960 s affected the structure of the self and subjectivity in postwar Japan. The fragmentation of national unity into groups with conflicting interests paralleled a fragmentation of subjectivity that in turn affected gender identities and led to new configurations of bodies and sexual relationships.'

I will analyze films about women made by Imamura Shōhei, Yoshida Kiju and Hani Susumu arguing that these films make visible gender politics in Japan's postwar society. These films explore the role played by historical institutions such as the feudal family, the rural system of female exchange, the system of prostitution and the pervasive economic and social gender inequality in the configuration of female bodies and subjectivities. ${ }^{2}$ These three filmmakers expose the medium of cinema as a technology of gaze that tends to objectify the female body for male desire but they also envision a different way of seeing. In my analysis of the films I will outline the duality between the look and the gaze and I will point out the strategies used by these filmmakers to construct an ethical form of representation that recognizes the alterity of women.

\footnotetext{
'See Mark McLelland, Love, Sex and Democracy in Japan during the American Occupation (New York: Palgrave Macmillan, 2012), J. Victor Koschman, Revolution and Subjectivity in Postwar Japan (Chicago: The University of Chicago Press, 1996) and Isolde Standish, Politics, Porn and Protest: Japanese Avant-Garde Cinema in the 1960s and 1970s (New York: Continuum International Publishing Group, 2011).

${ }^{2}$ Throughout my dissertation I will refer to specific institutions that reinforce gender norms producing certain bodies and subjects. I use in introduction this generic term in order to highlight the shifting process of the outside that becomes inside, of social structures that form particular subjectivities through the disciplining of the body.
} 
The context of defeat in WWII, American Occupation and the failure of political protests in the 1960 s explain the political inclinations of the New Wave filmmakers. The focus on political issues is paralleled by a relentless exploration of subjectivity and the ways in which history impacts the consciousness of characters. ${ }^{3}$ These filmmakers politicize bodies, critiquing the repressive regime of the state, family and gender relationships. Their political commitment is also an expression of their self-reflexive cinematic style. I will analyze this self-reflexivity as a negotiation of the gender power inherent in the process of cinematic representation. Imamura, Yoshida and Hani regard cinema as a mode of intersubjective engagement with the world based on an ethical relationship between directors and the filmed subjects. In other words, they try to extricate themselves from the technologies of power that turn filmed bodies (especially female bodies) into objects. Their ethical position involves an encounter with female alterity that disrupts the filmmaker's illusory position of omnipotence or the power of the gaze as a gendered mechanism of representation. However, despite their ethical commitment, the cinematic exploration of bodies and sexuality becomes nevertheless entangled in visual technologies that reenact the power of the male gaze. I will refer to Imamura, Yoshida and Hani as New Wave filmmakers, given their experimentation with cinematic technology and political stance. There are some controversies regarding the extent to which we can use the term "New Wave" and in order to answer them, I will offer an outline of previous theories and define my own position.

\footnotetext{
3 The postwar debates on subjectivity in Japan focused on the issue of individual agency in social and political life. Miyagi Otoya defined seven meanings of subjectivity and for the purposes of this dissertation I will use the meaning of self-possession and inner freedom, rather than the capacity to influence the outside world. See Victor J. Koschmann, Revolution and Subjectivity in Postwar Japan, (Chicago: University of Chicago Press, 1996). Having power of decision over one's body is the most basic form of subjectivity, a trope of permanent struggle for women.
} 
There are two important studies of the Japanese New Wave as a movement in English, besides studies of individual New Wave filmmakers such as Maureen Turim's Ōshima Nagisa Images of a Japanese Iconoclast (1998). Isolde Standish's book, Politics, Porn and Protest: Japanese Avant-Garde Cinema in the 1960s and 1970s (2011) and David Desser's Eros + Massacre; An Introduction to the Japanese New Wave Cinema (1988), explore the new style and the specific subject matter of filmmakers in the 1960s. All three scholars address the (mainly) independent filmmaking in the 1960's as a movement with certain configurations and particular aesthetics, an approach I will extend through my dissertation while focusing on the specific political and ethical issues in the representation of female bodies by male directors.

Maureen Turim situates her study of Ōshima Nagisa within contexts of innovation in the $1960 \mathrm{~s}$, more specifically, what she calls "iconoclasm." The iconoclasm of this period was manifested not only in the establishment of independent studios like Art Theatre Guild (1962) or the departure of young filmmakers from major commercial studios like Nikkatsu or Shochiku, but also an iconoclasm directed at national institutions, a form of political dissent that pervades most of the works in this period. ${ }^{4}$ Although there are commonly shared concerns and themes, in formal terms there is no consensus over genres and conventions, which are very different even for a single director like Öshima. ${ }^{5}$ For this reason, the Japanese New Wave is seen less like a unified movement, since there was no manifesto or explicit intellectual community, and more like a critical historical moment in cinema manifested through strong counterculture tendencies and personal involvements of directors in the act of

\footnotetext{
${ }^{4}$ Oshima Nagisa's departure is the most famous.

${ }^{5}$ Maureen Turim, The Films of Ōshima Nagisa; Images of a Japanese Iconoclast (Berkeley: University of California Press, 1998), 15.
} 
filmmaking. The films of New Wave directors are read as reflections on the political and intellectual life in the 1960s Japan and the purpose of my analysis is to zoom in on the more obscure reflection on the political dimension of women's bodies.

Whether we use the terms "avant-garde cinema" as Standish, "New Wave directors" as Desser or Satō Tadao's more sociologically inclined term "developments in the 60s," there is a consensus among critics that many filmmakers in this period shared common themes, subjects and even approaches to filmmaking even though there was no self-named unified movement. ${ }^{6}$ Many directors rejected being categorized as members of a movement. Desser defines the New Wave films as "films which take an overtly political stance in a general way or toward a specific issue, utilizing a deliberately disjunctive form compared to previous filmic norms in Japan." He associates the Japanese New Wave rebellion and protest with the French New Wave as a rupture with cinematic past due to specific cultural and political circumstances. Filmmakers in this period engage with their own historical moment challenging Japanese identity, commercial conventions of cinema and the previous generation of filmmakers. ${ }^{8}$ Imamura, Yoshida and Hani explore issues of repression, power and sexual desire revealing the structuring of female subjectivity through the body's interaction with power structures.

Standish frames her analysis of a group of films in this period using Bourdieu's opposition between commercial and non-commercial cinema and she carefully avoids the problematic New Wave category. She undertakes the study of New Wave in terms of an art cinema arguing that the "subjectivity and uncertainties

\footnotetext{
${ }^{6}$ Satō Tadao, Currents in Japanese Cinema, tr. by Gregory Barrett (Tokyo: Kodansha Amer. Inc. 1987), 211.

${ }^{7}$ David Desser, Eros + Massacre (Indianapolis: Indiana University Press, 1988), 4.

${ }^{8}$ See Turim, The Films of Öshima Nagisa, 1, 23.
} 
of the Bergsonian-derived 'time-image"' manifested in the avant garde experimentation of New Wave filmmakers are the result of a double crisis of truth in Japanese society and politics: the crisis of the loss of war and the failure of democracy. ${ }^{9}$ Extending her argument, the films I analyze show that there is also a crisis of gendered identities in this period that led many filmmakers to interrogate the relationship between sexuality, bodies and politics. Sexuality comes under scrutiny as the foundation of identity and subjectivity. The issue of male identity in the representation of New Wave cinema has been discussed at length but there are fewer studies concerned with the issue of female sexuality, more specifically, how female subjectivity emerges through the inscription of the body with sexual norms. Turim's study of Öshima Nagisa, the best known representative of the Japanese New Wave cinema has pointed out the prevalent representation of rape in his films as a trope "that operates rhetorically to literalize what we mean by 'the force of desire.' "10 ${ }^{\circ}$ shima's films highlight the violence of desire and the establishment of male subjectivity through the power over the female body in sexual relationships. Although Ōshima's films critique Japanese traditional institutions and they are self-reflexive about the political interventions of cinematic representation, I do not think he engages with the issue of female subjectivity in an ethical manner. His cinematic technique is based on the construction of male gaze as an appropriation of the female body for male pleasure and in that sense women in his films remain the Other. This reason, coupled with the vast amount of research already existing about Ōshima's work, explains why I have not included him in my study.

The merit of Standish's book is that she carefully contextualizes the filmmakers she studies against the historical and social changes in the 1960s. She is

\footnotetext{
${ }^{9}$ Standish, Politics, Porn and Protest, 6.

${ }_{10}$ Turim, The Films of Ōshima Nagisa, 259.
} 
also paying attention to the analysis of form and what she calls "the aesthetics of economy" that link filmmakers in this period. "' Avoiding the auteur paradigm, she uses the concept of "New Wave directors" as the "field of cultural production." I I will resume here the traits shared by New Wave Japanese filmmakers pointed out by the above-mentioned scholars. In terms of production, the 1960s saw the establishment of independent studios or schools. The reliance on small budget and less expensive equipment promoted the artistic autonomy of the filmmaker. The technical form shared by New Wave films involves the use of black and white film stock, cinemascope photography, iconoclasm and innovation. In terms of content, these films deal with themes that reflect personal involvement, preoccupation with desire, subjectivity and fracture points in Japanese identity. These films target intellectual audiences purporting more to reveal and critique their contemporary social issues than to entertain.

Like Desser and Standish, Yomota Inuhiko, a Japanese film scholar who wrote extensively on New Wave filmmakers, hopes that researchers can discover an "aesthetic unconscious" that connects filmmakers in this period despite their ostensible differences. ${ }^{13}$ This dissertation throws light on one aspect of the New Wave "aesthetic unconscious," arguing that the directors' view of cinema as a form of subjective engagement with the Other produced a self-reflexive cinematic style that negotiated the gender hierarchies inherent in the cinematic representation. What I would like to add to previous studies of the Japanese New Wave cinema is an analysis of gender, sexuality and power both in terms of the content of the films and in terms of their visual aesthetic. As Bill Nichols has pointed out, there is a close relationship

\footnotetext{
"Standish, Politics, Porn and Protest, 9.

${ }^{12}$ Ibid., 149.

${ }^{13}$ Yomota Inuhiko, "The Genealogy of the Mother," In Yoshida Kiju-50 Years of Avant-Garde Filmmaking, Ed. Dick Stegewerns (Oslo: Norwegian Film Institute, 2010), 51.
} 
between style and moral outlook or political point of view. ${ }^{14}$ What do these films tell us about female embodiment in the Japanese postwar period and about the filmmakers' stance towards the gendered politics of cinematic representation?

Scholars of the Japanese New Wave situate the filmmakers active in the 1960s and 1970 s within their particular historical and cultural context. They point out the filmmakers' direct engagement in the political issues of their contemporary world. I would like to press further the political dimension of their films interrogating their representation of the female body as an interface between heteropatriarchal institutions and female subjectivity. This is an issue of importance given the fact that these films were made in a context where cinema was increasingly moving towards the commodification of the female body, as I will explain below. The postwar years marked a shift from the focus on the maternal body supported by the militarist ideology, to the focus on women's sexual bodies. ${ }^{15}$ This transformation contributed little to women's sexual liberation since it shifted the ideological state power over female bodies to institutions that objectified and commodified them. There is a marked contrast between the postwar discourses on the male body and those on the female body.

The issue of the body in postwar Japan has been the subject of Doug Slaymaker's book, The Body in Postwar Japanese Fiction (2005), Yoshikuni Igarashi's Bodies of Memory (2000) and Mark McLelland's Love, Sex and Democracy in Japan During the American Occupation (2012). All three scholars argue that the postwar years celebrated the liberation of the sensual body. The bodily deprivation

\footnotetext{
${ }^{14}$ Bill Nichols, Representing Reality: Issues and Concepts in Documentary (Bloomington and Indianapolis: Indiana University Press, 1991), 80.

15 The ideology of the maternal body supporting Japanese national identity in the wartime period safely erased the abuse and abjection of the colonized women's bodies.
} 
suffered during the war both in terms of its immediate needs like food and shelter and in terms of its erotic energies repressed during the militarist regime made place for an intense focus on the body as a locus of pleasure, truth, and freedom from state power. Critiquing the historical contingency of ideology and its fundamentally misleading nature, many intellectuals turned to material embodiment as the only form of stability and truth. However, this formulation of the body is a gendered discourse that overshadows the more complicated issue of the female body.

Slaymaker explains how the kokutai (nation body) ideology turned into nikutai (carnal body), which he follows in literary representations of nikutai novels written by male and female writers. ${ }^{16}$ He defines the kokutai as the national body close to a state religion with the emperor at its apex and the people as part of a body space. While this concept was used in the wartime years for establishing Japanese uniqueness and masculine domination after defeat, Japan was feminized and turned into a colonial Other. ${ }^{17}$ Slaymaker argues that there was a strong preoccupation in the postdefeat years with the material body, the nikutai as a form of liberation from the constraints imposed by the wartime regime. ${ }^{18}$ The opposition between the national body (kokutai) and the body of pleasure (nikutai) is possible for the male body since male identity was closely connected to national ideology. Moreover, the body of pleasure presupposes a relational materiality based on the supremacy of male desire. Nikutai writers imagined female bodies as sources of liberation and wholeness for the male subject, whereas Slaymaker does not detect any sign of liberation of the female body in women's writings. My dissertation follows the discourses surrounding the female

\footnotetext{
${ }^{16}$ Douglas Slaymaker, The Body in Postwar Japanese Fiction (London and New York: Routledge Curzon, 2004), 8.

${ }^{17}$ Igarashi, Bodies of Memory, 35.

${ }^{18}$ Slaymaker, The Body in Postwar Japanese Fiction, 11.
} 
body in the 1960s films arguing that the liberation of the male body produced new forms of power over the female body.

McLelland argues that courtship behavior and sexual relationships in the postwar years were highly influenced by American models. He places male-female dating and courting interaction among the most notable changes brought by the Occupation. The process of democratization was promoted in opposition to the feudal restriction of individual bodily behavior. ${ }^{19}$ Sexual pleasure emerges as a strong mark of the body, as an energy that defies state control but this narrative expresses mainly men's discourse of the liberating potential of the body of pleasure. The liberation from militarist surveillance and censorship made way for new forms of regulating female bodies and sexuality. The celebration of sexuality creates a new grip of power over women's bodies that will be channeled towards their commodification in various forms of media. The removal of militarist censorship regime and finally, of the Occupation censorship meant increasing access to sexualized representations of women. At the same time, the radical changes of Japan's postwar years were also important for the liberation of the female body from rigid social norms and they made possible women's increasing preoccupation with sexual love and its liberating potential. The films I chose for analysis reveal the struggle between female subjectivity and the inscription of female bodies by gender norms. They also represent what love, sexuality and the body of pleasure meant for women in the postwar context, historicizing embodiment and affect. I will attempt to answer two questions in this dissertation. What are the cinematic strategies used to represent female bodies in a context that allowed filmmakers a greater degree of freedom to explore sexuality

\footnotetext{
${ }^{19}$ McLelland, Love, Sex and Democracy in Japan, 3.
} 
in cinema? What are the ethical implications and the power structures at play when male filmmakers represent female bodies and experiences?

This dissertation aims to offer a feminist analysis of the representation of female bodies in New Wave Japanese cinema, an aspect of scholarship sorely missed in studies of Japanese cinema. My argument is that these films self-reflexively analyze the cultural dimensions of eroticism and sexuality in the construction of female bodies. What is important for my analysis is the concern of New Wave filmmakers with women's relationship to power, sexuality and female identity. The fight against the repressive regime of cultural institutions is associated by many postwar (male) intellectuals with sexual liberation but this becomes possible through the further (often violent) objectification of women. This is a trait manifested in the nikutai bungaku, (literature of the flesh) the taiyozoku (sun tribe) films and the increasing number of pornographic genres during the 1960s.

Satō Tadao observes that in the 1960's there were two major subjects in films: sex and violence. ${ }^{20} \mathrm{He}$ explains this phenomenon as a result of the lifting of censorship, competitive commercialism and most essential, a change in the audience composition and in the interests of a new generation of directors. The rivalry with television forced the major cinema studios to come up with inventive market strategies. Many major studios turned to the exploitation of sex and violence in an effort to win the interest of larger audiences mostly made up of unmarried, working class youth migrating to the city. The best-known example is Nikkatsu, a studio that enjoyed important financial successes with the production of gangster and youth films

\footnotetext{
${ }^{20}$ Satō, Currents in Japanese Cinema, 229.
} 
like the taiyozoku genre in the 50 s and later with pornographic films. ${ }^{21}$ From the first kiss shown in Japanese cinema in 1946, A Twenty-Year-Old Youth (Hatachi no seishun, Sasaki Yasushi) to the taiyozoku genre in the 50s and the first pinku film in 1962, Flesh Market (Nikutai no ichiba, Kobayashi Satōru), sexuality increasingly became a topic that in the 1970 s would become the highest grossing genre with pinku and roman poruno films surpassing the yearly output of the five major film studios. ${ }^{22}$ By 1965 the pinku film accounted for forty percent of the domestic production. ${ }^{23}$

The representation of sexuality in many New Wave films, pinku films or roman poruno differs considerably. While the last two categories portray sexuality with the intent of creating body genres appealing to spectators' bodily senses through the spectacle of nudity and pleasure, the representation of sexuality in the case of New Wave filmmakers is a starting point for reflection on power, repression and cultural institutions. Throughout my dissertation I argue that these films express at the visual level the duality between the male gaze and the look, and at a narrative level the struggle between patriarchal forms of power and female subjectivity. Sato explains the preoccupation with sex of these filmmakers as a means to explore at a bodily, emotional level, larger political issues. "Fundamental human problems such as the relationship between rulers and ruled, can also be seen in the male female relationship." 24 Rather than tropes for real versus metaphoric power relations, gender relationships in fact reflect larger social and institutional forms of power. Many New Wave filmmakers critique state power, institutional domination and sexual repression

\footnotetext{
${ }^{21}$ Taiyōzoku films, literally translated as the "Sun Tribe" refers to a minigenre of films produced at Nikkatsu, mainly based on Ishihara Shintaro's books, portraying the nihilism and cynicism of the younger generation adrift in a meaningless world. They represent a hedonist youth culture, celebrating consumerism and eroticizing both the male and the female body.

${ }^{22}$ Satō, Currents in Japanese Cinema, 229. For a more detailed definition and history of the pinku film as a soft-core pornographic genre, see Jasper Sharp, Behind the Pink Curtain: The Complete History of Japanese Sex Cinema (London: FAB Press, 2008).

${ }^{23}$ Sharp, Behind the Pink Curtain, 75.

${ }^{24}$ Satō, Currents in Japanese Cinema, 233.
} 
but not many of them were aware of the gendered politics of fighting repression. In other words, many other filmmakers in the postwar era represented the male liberation from repression based on the objectification of the female body, such as Ōshima Nagisa, Suzuki Seijun and the taiyozoku films. Contrary to this tendency, Imamura, Yoshida and Hani reflect on this form of male liberation and its consequences for women.

There are many important studies of Japanese cinema but I have yet to come across a thorough feminist analysis of the Japanese New Wave films that would question the power played by Japanese historical institutions in the appropriation of female bodies (including the institution of cinema) and explore the interplay between the representation of female bodies as objects of desire and as the material manifestations of female subjectivity. ${ }^{25}$ The purpose of this dissertation is to address this lack through a double-layered analysis. First, I will examine the role played by the institution of cinema in the representation of female bodies through the analysis of films about women made by Imamura Shōhei, Yoshida Kiju and Hani Susumu. Secondly, I will analyze films made by these three directors that portray women's embodiment as a form of historical becoming, politicizing gender and sexuality. This dissertation interrogates the traits that made some critics refer to Imamura, Yoshida and Hani as feminists, exploring the critique of cinema and of patriarchal power offered by the films' self-reflexive representation of the duality of female bodies as subjects and objects. I will argue that their feminism lies in the ethical negotiation of the gender power inherent in the hierarchy of male directors as (disembodied) subjects and filmed women as embodied objects. Since feminism is concerned with a recuperation of women as subjects and with the analysis of the cultural construction of

\footnotetext{
${ }^{25}$ The Japanese film scholar, Saitō Ayako is an exception. She analyzes many Japanese films from a feminist point of view.
} 
femininity through a critique of patriarchal norms, I will argue that these directors employ feminist strategies that portray the becoming of woman through the systematic disciplining and appropriation of female bodies by heteropatriarchal institutions.

Satō Tadao was the first critic to define the feminism of Japanese directors through his analysis of Mizoguchi's representations of women. He outlines the feminism of some Japanese male filmmakers based on the portrayal of women's suffering. However, the representation of women's suffering and oppression turns women into victims without taking into account larger social and political implications. Yoshida's argument about the representation of women in his films summarizes very well the differences between Mizoguchi's feminism and New Wave filmmakers' feminism. "Not that I'm criticizing Mr. Mizoguchi, but the women in his films are women seen from a male point of view....He had a certain idea of the essence of women, or the sexuality of women, and of course it had a certain reality. But still it is just women seen by Mr. Mizoguchi. There is no looking back from the side of women, looking back at men; no exchange of gazes happens between male and female." ${ }^{, 26}$ This exchange of gazes is what I will argue the films in this dissertation perform. I will argue that Imamura, Yoshida and Hani avoid the Othering of the female and the appropriation of the female body by male desire since they portray the negotiation between men and women, bodies and institutions, the gaze and the look. All three directors interrogate the power inherent in gender relations and cinematic representation by analyzing the interplay between the female body as the material manifestation of female subjectivity and as an object of vision and desire. Although they did not entirely avoid the representation of women as object bodies Imamura, Yoshida and Hani problematized the centrality and omnipotence of the male gaze,

\footnotetext{
${ }^{26}$ See Chris Fujiwara, "Interview with Yoshida Kiju," In Yoshida Kiju-50 Years of Avant-Garde Filmmaking, ed. Dick Stegewerns (Oslo: Norwegian Film Institute, 2010), 8-14.
} 
envisioning an ethical look that represented women as subject bodies. While the question of the filmmakers' feminism is central to my analysis, I will refer to their filmmaking strategies as ethical engagements with the Other that parallels other forms of gender relationships involving love, desire and power.

The difference between the gaze and the look has been usefully formulated by E.Ann Kaplan (1997). Her differentiation allows for an intersubjective dimension of communication in general and of filmmaking in particular. The look is governed by curiosity about the Other, by closeness and intimacy while the gaze is a one way subjective vision governed by anxiety or desire and constructed as "an attempt not to know, to deny even." ${ }^{27}$ The gaze destabilizes subjectivities by investing them through the authority of the eye, it has the power to contain, define and appropriate. The look is open to negotiation and dialogue, it is mutual and enhancing rather than constraining and it is based on connection. The look is not predicated on a centralized, enclosed and self-sufficient form of subjectivity. The three directors whose films I will analyze in this dissertation attempt to look and make us as spectators look at women and with women rather than gaze at them. However, they cannot escape the power structures inherent in the institution of cinema and the role of the male gaze in the construction of female sexuality.

In terms of a formal analysis of the films I will use the distinction between the gaze and the look problematizing the relationship between them both through the study of film and of the filmmaker's own definitions of filmmaking. My analysis of the body politics represented in the films will explore the in-between spaces between bodies, the capacity to act on and be acted upon, in sum, bodies as interfaces between

\footnotetext{
${ }^{27}$ E. Ann Kaplan, Looking for the Other: Feminism. Film, and the Imperial Gaze (New York: Routledge, 1997), xvi.
} 
the social world and inner subjectivity. Neither subjectivities nor bodies are enclosed entities that we can scrutinize in separation from their interaction with other bodies and subjectivities. I will treat female bodies as interfaces between institutions reinforcing gender norms and female subjectivities. My analysis is informed by phenomenological film theories that explore bodies as interconnected ways of being in the world and a feminist analysis of power concerned with the disciplining of bodies.

This dissertation will explore the confluence of two tendencies noticeable in the preoccupation of Imamura, Yoshida and Hani. One is the representation of sexuality not only as an expression of bodily pleasure but also as political struggle against repressive ideological forces of society. The other tendency is the exploration of sexuality both from a male point of view and from a female point of view. While political and sexual repression is an urgent issue for most of the filmmakers in this period, the films I will analyze in this dissertation films portray the multiple layered repression of female sexuality performed by social institutions and the apparatus of cinema. The strategy of politicizing female bodies and opening up a space for a female perspective is ultimately an ethical engagement involving respect for what Emmanuel Lévinas refers to as the infinite alterity of the Other, in this case, the alterity of women. ${ }^{28}$ It also refers to the interrogation of the self in its relationship to the other. All three directors I analyze in this dissertation negotiate their social and institutional positions of authority as male directors and they attempt to articulate what bodies meant for women themselves.

In the first chapter I will offer an interdisciplinary account of theories about the representation of the body in cinema. More specifically, I will analyze how

\footnotetext{
${ }^{28}$ See Emmanuel Lévinas, Humanism of the Other, tr. by Nidra Poller (Chicago: University of Illinois Press, 2003).
} 
feminist theories of the gendered body have influenced feminist film theories, focusing on an analysis of the power inherent in the cinematic apparatus as a medium that creates desire. I will argue that feminist theories of cinema are divided along the binary between the look and the gaze. Scholars like Laura Mulvey, Mary Ann Doane and E. Ann Kaplan are concern with the role of power in representation, especially the objectification of the female body in cinema. In my analysis I intend to go beyond the indictment of the cinema as a medium that objectifies female bodies, considering the potential of cinema as an instrument of understanding that implies human responsibility and ethical negotiation. For this reason, I will bring into dialogue these theories that critique the power of the male gaze with phenomenological accounts of the body in cinema proposed by Vivian Sobchack. Her accounts of the body in cinema shift away from the strict object-subject relations of power in looking, accounting for the embodied, perceptual experience involved both in film production and in film viewing. Cinema makes visible various techniques of the body through its multisensorial representation.

In the second chapter I will zoom in on Imamura Shōhei's two fiction films, Insect Woman (Nippon konchüki, 1963) and Intentions of Murder (Akai satsui, 1964) analyzing the dialectical relationship between female subjectivity, bodies and Japan's cultural institutions, including the institution of cinema. My approach will be based on feminist theory and Japan's historical and cultural specificity to rework the Foucauldian framework of the body's inscription by power. Imamura's realistic style and his employment of the camera as an objective anthropological tool meant to capture women's bodily experiences perform a radical critique of gender norms in postwar Japan. These two films portray tenacious and assertive female characters who must learn various skills to survive a patriarchal society that restrict them to their 
sexual and procreative bodies. They make visible the female body as a place of struggle between violent institutions and subjectivities. Pleasure and intimacy for women are undermined by the structures of the feudal family and the prostitution system that require docile female bodies. I would like to press further the fascination with the endurance and survival of Imamura's female characters and analyze the emergence of femininity through violent rituals meant to discipline the female body. The history of Japan is explored from an embodied female perspective and an analysis of Imamura's films can tell us more about Japan's embodied history and about the gender inequality permeating social institutions.

The third chapter analyzes Imamura's documentaries about women focusing on the impact of Japan's economic expansion in Asia between 1870 and 1930s and Japan's postwar Occupation on the configuration of the female body. I will focus on Imamura's two documentaries, The History of Postwar Japan as Told by a Bar Hostess (Nippon sengoshi -- madamu Onboro no seikatsu, 1970) and Karayuki-san, The Making of a Prostitute (Karayuki-san, 1975), exploring the points of convergence and conflict between women's memories of personal, embodied experiences and Japan's postwar history. In this chapter I will analyze the female body as sanctioned boundary marker between national identities, outlining both the oppression and the liberation that this body positioning meant for women. Japanese women of lower caste confront Japan's official histories of modern globalization, defeat in the war and American Occupation with the stories of their embodied experiences that reveal the close relationship between the personal and the political. In parallel to the analysis of the films' narrative and visual discourse, I will consider Imamura's ethics of documentary filmmaking as a self-reflexive negotiation of gender power. Both documentaries use the voices of women and their bodily experiences to counteract the 
homogenous national discourse and to reveal the placement of the female body as the sexual boundary of the nation. My analysis of the films will follow the fractures and the encounters between national discourse and personal experience, between voices and images, ethics and aesthetics.

In the fourth chapter I will analyze Yoshida Kiju's Eros + Massacre (Erosu + gyakusatsu, 1969), which explores the configuration of love and sexuality in the 1960 s by returning to Ōsugi Sakae and Itō Noe, two historical figures in the 1920s, anarchists and advocates of free love. This chapter will be concerned with the political dimension of male and female bodies, focusing on the impact of historical transformation on the configuration of love and sexuality in the 1960 s and the 1920 s. The film's construction of time is crucial for understanding the relationship between bodies and history. The sexual freedom enjoyed by the characters in the $1960 \mathrm{~s}$ is haunted by alienation due to the lack of emotional, subjective involvement that can be retrieved by returning to the past. The configuration of sexual love in the past is predicated on the unity between body and emotion, between sex and love as a form of individual freedom and self-realization haunted by the norms of the family, state power and the gendered division of labor. The female body is represented both as subject and as object of desire and sexual love is portrayed as mutual negotiation between male and female subjects that questions gender hierarchies. I will also analyze in this chapter Yoshida's feminist strategies of ethical negotiation between him as a male director and Okada Mariko as actress.

The last chapter analyzes the binary relationship between love and power, the look and the gaze, innocence and exploitation in Hani Susumu's Nanami, The Inferno of First Love (Nanami, hatsukoi jigokuhen, 1968). These binaries appear to exclude each other as two irreconcilable aspects of the subject's engagement with others but I 
will argue that the film shows their coexistence in the same person and in the same mode of cinematic representation. I will follow in my analysis of the adolescent body the dialectic between love as emotional potential that recognizes the alterity of the Other and power as the appropriation of the human potential towards utilitarian goals. The film self-reflexively represents the production of erotic female bodies and the eroticization of violence against the female body.

I will demonstrate in this dissertation that the crisis of (male) subjectivity in postwar Japan generated ethical possibilities of filmmaking that negotiated the power inherent in gender relationships and cinematic representation. I will argue that these films offer a politicized representation of the female body as an embattled interface between female subjectivities and the power of heteropatriarchal institutions. 


\section{Chapter One. Bodies as Subjects and Objects-An Interdisciplinary Consideration of Gendered Bodies in Cinema}

Conditions of embodiment are organized by systemic patterns of domination and subordination, making it impossible to grasp individual body practices, body regimes and discourses about the body without taking power into account. ${ }^{1}$

The scope of this dissertation is an interdisciplinary research situated at the convergence of three fields: Gender Studies, Film Studies and Japanese Studies. In the introduction I highlighted theories of the body informing studies of Japan. In this chapter, I will outline my methodology and theoretical underpinnings regarding the approach to the body. The main point of convergence between Gender Studies and Film Studies is an analysis of the power invested in the subject-object relations of looking and cinematic representation. Both body theories and feminist film theories denounce the problematic nature of the objectification of female bodies in real life and in visual representation. "Viewing is always a potentially charged encounter," because of the power mechanisms inherent in gender relations and cinematic production. ${ }^{2} \mathrm{I}$ will show in this chapter the influence of gender and body theories on feminist film theory, bringing into dialogue the feminist analysis of the male gaze with phenomenological theories that complicate the binaries between subject and object in film perception and representation.

Contemporary body theories go beyond the nature nurture debate that has been haunting gender studies. Instead of asking whether gender is the result of sex or sex the result of gender, body theories focus on the interdependent relationship between mind and body, nature and culture, subjectivity and ideology. Until recently, bodies

\footnotetext{
' Kathy Davis, "Embody-ing Theory: Beyond Modernist and Postmodernist Readings of the Body," In Embodied Practices, Feminist Perspectives on the Body (New York: Sage publications, 1997), 1-27, 14.

${ }^{2}$ Lisa Downing and Libby Saxton, Film and Ethics, Foreclosed Encounters (New York: Routledge, 2010), 92.
} 
were the exclusive object of the sciences of biology and medicine, defined as unchanging parts of nature. These disciplines (at least the Western ones) have constructed bodies as bounded, self-sufficient entities defined through anatomy (the visual structure of our material bodies) and physiology (the study of the functioning of the body). The body has been a feminist concern from the beginning of feminist activism, since much of women's subordination was considered a result of their embodiment in a patriarchal society. Race, gender and class have emerged as important categories for exploring the power relationship involved in the production of hierarchical bodies. These categories have also challenged many definitions about the nature of the bodies exposing how science has ignored its contextual historicity proclaiming to determine the unchanging truth of the body through the power of disembodied reason. I cannot do justice to all major theories of the body so I will limit myself to mentioning a few studies that have radically changed the ways in which we think about embodiment.

Michel Foucault has convincingly argued that the body is vital component of power relations in society, a site in which personal bodily practices are connected to larger institutions of power. In Foucault's own words, "the naturalization of the power through the body required to be docile in its minutest operations." 3 Bodies are not natural, material categories in opposition to discourses, since they are continuously produced and mobilized by a power disguised as objective knowledge about the body's nature. The body is thus not a manifestation of natural individual existence but a fundamentally social and historical category. Subjection of the body to institutional power is the precondition for the very existence of the subject. Subjection creates coherence and meaning for the subject, a model and a norm of behavior that confers

\footnotetext{
${ }^{3}$ Michel Foucault, Discipline and Punish: The Birth of the Prison, tr. by Alan Sheridan (New York: Vintage, 1995).
} 
identity. This identity acts according to Foucault in terms of a soul that masters the body mediating the power exercised on it from outside through self-surveillance. Sexuality is a privileged locus for disciplinary power because it penetrates "both the life of the body and that of the species." In other words, discourses on sexuality are the most powerful forms of biopower since they regulate both the reproduction of individuals and of populations. Bodies are thus for Foucault marked with the imprint of history and institutional power while sexuality is one of the most sophisticated means of discipline. Power, both discursive and visual operates as a cluster of forces having at the center bodies and subjectivities. Feminist theories of the body go further than Foucault, keeping in focus both the inscription of bodies with institutional power and the resistance of these bodies inhabited by subjectivities. Foucault's insights have been problematized and taken further by feminist theorists such as Susan Bordo, Elisabeth Grosz and Iris Marion Young.

Elisabeth Grosz argues that women's oppression is closely connected to the status of the body in a given culture. She points out how many important male theorists of the body have taken the male body as the norm, ignoring or minimizing the importance of sexual difference for our perspective on the world and the production of knowledge. Western theory and philosophy have been concerned with suppressing or minimizing the importance of our bodies for the production of knowledge. Feminist theorists of the body are trying to recover the relationship between body and mind, between individual subjectivity and collective history. I will situate my research along these efforts to historicize and politicize bodies by paying attention to female bodies as sites of struggle between various forms of power and female subjectivities.

\footnotetext{
${ }^{4}$ Foucault, History of Sexuality, tr. by Robert Hurley, vol. 1 (New York: Vintage, 1990), 75.
} 
Grosz uses the metaphor of the Möbius strip in an effort to transcend the dualism between gender and sex. This model shows the inflection of mind into the body and the body into the mind without disconnection, without a stopping point. The surface of the body (and the external constraints that impinge on it) leads to its depth, which in turn, circulates back on the surface of the body in a constant movement. This circulation gives a more detailed and accurate view of the ways in which our bodies are embedded in the space and time of specific cultural contexts. This model has served as an important reference point for my analysis of the cinematic representation of female bodies. I will analyze bodies as interfaces between individual selves and social institutions, as both subjects in themselves and objects for others.

Susan Bordo reflects on the ambiguity that lies at the heart of the embodiment of femininity, which, even at its most empowering can be debilitating and the other way around. She is able to account for this ambiguity because she tries to bridge the gap between symbolic representations of female bodies and praxis. For Bordo the female body is problematic both because technologies of discipline exercise more control over it than over male bodies and because discourse itself silences it. ${ }^{5}$ For this reason, the struggle of feminist theories is dual; on one hand researching the diversity of experiences of embodiment and on the other undermining the homogenizing, universalizing dimension of theory defined as objective, disembodied and omniscient. She used Bourdieu's idea of the habitus, arguing that it is not through ideology but through "the trivial daily gestures and minute regulation of time, space and movement that our bodies become impressed with the stamp of prevailing historical norms of

\footnotetext{
${ }^{5}$ She comes to this conclusion after her study of female eating pathologies and their medical treatment. See Susan Bordo, Unbearable Weight: Feminism, Western Culture, and the Body (Berkeley: University of California Press, 1993).
} 
selfhood, desire, sexuality." In my analysis of the films I will focus on this regulation of the bodies' time, space, movement and visual surface in order to show the construction of particular forms of subjectivity, desire and sexuality.

Iris Marion Young is another important figure in the theories of the body and her theories inspired phenomenological film theorists such as Vivian Sobchack, whose insights inform the premise of my approach to films. Young closely explores the female body in given situations, defining the relationship between environment and the immediate material facts of the body. "Gender, I suggest there, is best understood as a particular form of the social positioning of lived bodies in relation to one another within historically and socially specific institutions and processes that have material effects on the environment in which people act and reproduce relations of power and privilege among them." ${ }^{, 7}$ Young successfully bridges the gap between phenomenology as the analysis of the lived body and structural analysis of social institutions.

A common thread that runs through most feminist studies of female bodies is the idea of alienation, of gap between women's perception of their bodies and various cultural definitions of their bodies as well as a constant state of self-surveillance. As an institutionalized mode of representation cinema participates in the reinforcement of gender hierarchies but it also has to potential to question them. I will demonstrate in this dissertation that Imamura, Yoshida and Hani negotiate and at times, critique the power inherent in the subject-object relations between directors as subjects and filmed women as object bodies, between female bodies as the sites of women's pleasure and agency or female bodies as objects of male desire. The emergence of body theories in the last decade produced a theoretical approach based on complex models that account

\footnotetext{
${ }^{6}$ Bordo, Unbearable Weight, 14.

${ }^{7}$ Iris Marion Young, On Female Body Experience: 'Throwing Like a Girl' and Other Essays (London: Oxford University Press, 2005), 22.
} 
for historical contingency and continuous transformation. How have these theories influenced the ways in which we theorize the representation of bodies in cinema?

While cinema has been from its beginnings a medium closely associated with representation of bodies, there were surprisingly few studies about the topic. That scarcity is now a thing of the past, given the explosion of theories about cinema, gender and bodies in the last thirty years. I will start with an outline of the theories that analyze the presence of bodies in cinema, moving on to feminist theories that analyze how power, gender and sexuality inform the representation of bodies. I will outline here three categories of studies dealing with the topic of the body in cinema: theories focusing on the reproduction of bodies as images through technological means, feminist theories concerned with the power of the medium, and phenomenological theories.

In the history of film theory there are two prominent authors who have analyzed the relationship between cinema and real bodies but they did so from the point of view of the technological dimension of the camera. André Bazin associated cinema with the act of embalming since the technological dimension of the camera could remove bodies and aspects of reality from the flow of time and the constraints of space. Cinema performed "the preservation of life by a representation of life" creating a strong ontological link with reality. ${ }^{8}$ The trace of living bodies is anchored in images for eternity defying their ontological mortality. The camera as a technological instrument removed the human intervention in representation creating a trace of reality. The metaphor of embalming brings Bazin close to Walter Benjamin and Mike Featherstone, two other authors I will consider here.

\footnotetext{
${ }^{8}$ André Bazin, "The Ontology of the Photographic Image," In Film Theory and Criticism: Introductory Readings, eds. Leo Braudy and Marshall Cohen (New York and Oxford: Oxford University Press, 1999), 9-13, 10.
} 
For Walter Benjamin, cinema destroys the "aura" of reality through its mechanical reproduction of images consumed on a mass scale. ${ }^{9}$ While the concept of aura has been the subject of numerous interpretations, I will use it here to outline its meaning of existential continuity in time and space, the unique presence of people, works of art or natural phenomena at each moment. The camera foregoes the human interaction between bodies and their unique presence in time and space by replacing it with an alienating interaction between machine and bodies. Mike Featherstone echoes the same idea but with more political implications. Since his interest is not in defining cinema but in defining the effects cinematic representation had upon bodies, he argues that the images of bodies in cinema create a one-dimensional presence and unidirectional interaction based on visuality. Our interaction with other bodies through images is alienating because it is not based on affective, intense presence, on the mutual engagement of the senses in communication. ${ }^{10}$

Feminist theory goes even further in the indictment of the alienating effect cinema has upon bodies especially its support of patriarchal standpoints. Authors like Kaplan and Anne McClintock have pointed out that psychoanalysis, cinema and Western imperialism constituted specific modern paradigms of knowledge that turned the Western male model of knowledge and perception into a universal one. This model is based on the separation between subject and object epitomized by the primacy of visual perception that subordinates or erases other senses. The camera foregoes the intersubjective dimension of embodied presence when viewing other bodies, it constructs unilateral mode of seeing without being seen, of penetrating the

\footnotetext{
${ }^{9}$ Walter Benjamin. "The Work of Art in the Age of Mechanical Reproduction," In Illuminations, ed. Hannah Arendt, tr. by Harry Zohn (New York: Harcourt, Brace and World, 1968), 21 7-251.

${ }^{10}$ Mike Featherstone, "Body, Image and Affect in Consumer Culture," In Body and Society, 16 (2010): 193-221.
} 
secrets of others that they themselves don't know. ${ }^{11}$ Female bodies are spectacles both in their real lives and on cinematic images because the center of visual perception epitomized by the camera is a patriarchal point of view whose power structures both reality and cinema. Linda Williams points out the origin of cinema as "not only a psychic apparatus with a passion for perceiving and a technological apparatus that makes perception possible; we have... a social apparatus as well. And this social apparatus is what constructs women as objects rather than the subjects of vision." 2 Feminist film theory brought attention to the fact that images are not innocent, because they enact and further construct social hierarchies of gender and race. The camera does not record objectively things as they are, because the camera is manipulated by embodied subjects. Cinematic images both replicate and construct the subordination of the objects to be looked at to the subjects who look.

The most famous and at the same time the most fiercely criticized is Laura Mulvey's theory of the male gaze. She performed a penetrating analysis of the patriarchal underpinnings of cinema stating that "cinematic codes, through the manipulation of not only image but also the dimensions of time (editing, narrative) and space (changes in distance, editing) creates a gaze, a world and an object, thereby producing an illusion cut to the measure of [male] desire."13 Although limited by her reliance on a universalizing psychoanalytic model to account for her theory and by her analysis of classical Hollywood cinema as 'cinema,' Mulvey has nevertheless opened the path for understanding the relationship between film viewing and gendered ways of seeing.

\footnotetext{
${ }^{12}$ Linda Williams, Hard Core: Power, Pleasure and the Frenzy of the Visible (Berkeley: University of California Press, 1989), 45.

${ }^{13}$ Laura Mulvey, "Visual Pleasure and Narrative Cinema," In The Feminism and Visual Culture Reader, ed. Amelia Jones (London and New York: Routledge, 2010), 57-66.
} 
Linda Williams offered a thorough analysis of the interaction between the camera and bodies, defining melodrama, pornography and horror films as genres of the body. What is more important for my purpose is that in these genres "the bodies of women have functioned traditionally as the primary embodiments of pleasure, fear and pain." ${ }^{\prime 14}$ The emotions most closely associated with the body are brought to life onscreen through the images of female bodies who are both the "moved and the moving." $"$ Mulvey and Mary Ann Doane stress the objectification of the female body as sexual, as the surface of the image rather than its depths but Williams takes the issue further showing that the representation of the female body produces visceral emotions. Summing up, there are two main ideas about the female body and cinema: the objectification of female bodies through the male gaze: it stops the narrative as pleasurable spectacle (male gaze), the female body associated with surfaces and not depths. The other idea is that the representation of the female body moves spectators by being narratively or visually moved (appeal to lower emotions more connected to the body-thus the lower genres) in what Williams calls "body genres."

The urgency with which feminist film theorists undertake the critique of the patriarchal underpinnings of cinema reveals the importance that cinema has in the formation of subjectivities and worldviews. Rather than the camera objectively registering aspects of reality, behind the camera there have been embodied men that carried forth in images their perception about gender and sexuality with the appearance of objectivity. All these studies that focus on the relationship between cinema and bodies in terms of the production of images reveal a hopeless and somewhat dark vision of cinema as a patriarchal instrument of power, a one dimensional mode of human interaction based on distancing visuality, an essentially

\footnotetext{
${ }_{14}^{14}$ Williams, Film Bodies: Gender, Genre, and Excess," In Film Quarterly, 44. No. 4 (1991): 2-13, 4.

${ }^{15}$ Ibid.
} 
alienating medium through the human interaction with an instrument of technology. These theorists argue that cinema produces an act of alienation, of disembodiment even, given its technological and commercial production. The cinema as an apparatus mainly operated by men enacts a double grip of power over bodies, first, through the bodies interacting with technology and second, with female bodies performing the ideas, fantasies and values of male directors. Does cinema participate in the process of human alienation that many body theorists denounce as the problem of Western epistemology through the visual perception of disembodied images or does it deepen our understanding of embodiment through the close representation of bodily practices?

Cinema is an ambiguous medium, both based on an ontological relationship with reality and the transformation of reality through various means of representation. ${ }^{16}$ It alienates and impoverishes our embodied experiences, it destroys the aura of things and people, to paraphrase Benjamin, but at the same time one can argue it makes us more aware of the techniques of embodiment which, by virtue of the fact that they are naturalized onto our bodies, are harder to grasp through real experience. However, cinema as an apparatus produces itself techniques of the body. Feminist film theory has compellingly demonstrated that visual images not only reiterate patriarchal relations, they bear these relations in their very formal structure that privileges the visual perception over other senses and highlights the distance, the separation between the subjects and other subjects.

There is another more optimistic strand of studies that analyze the relationship between cinema and bodies in phenomenological terms with less focus on power

\footnotetext{
${ }^{16}$ I am referring here to cinema as it has been theorized before the advent of digital means that create a new kind of relationship with reality. See Lev Manovich, "Digital Cinema and the History of the Moving Image," In The Language of New Media (Cambridge: MIT Press, 2001), 298-308.
} 
paradigms. Rather than critiquing its alienating effect, these scholars point out the multiple effects cinema has on human perception. They also shift their attention from visual theoretical models, including sound and haptic characteristics of film that touch spectators engaging all their senses. Vivian Sobchak and Laura Marks are mainly known for their contribution to a film theory based on the embodied relationship to film inclusive of all bodily senses, not only the visual one, which has been the emphasis of most precedent theories. ${ }^{17}$ Laura Marks focuses on touch and smell, as two senses that overcome the distance between spectators and the unfolding of cinematic images. Her main contribution to the study of film is the introduction of the sensuous, the tactile and other forms of perception both in the production and in the reception of images. She rejects psychoanalytic theories and uses instead a phenomenological paradigm that takes into consideration the body and all its senses moving away from theories based on the supremacy of visual perception.

Vivian Sobchack draws on Merleau Ponty's phenomenology and other sources to challenge the distinctions between mind and body. Perception and praxis are key terms for Sobchack since the world (cinematic world included) is accessible to us through the intention of our embodied consciousness while being is always manifested in the world through one's actions and intentions. Bodies are for her both subjects lived from within and objects perceived by others from without. However, the gap between these two perspectives is most visible in the case of women whose bodies are in many instances the objects of other subjects' intentions. Perception is for Sobchak "the bodily perspective or situation from which the world is present to us and

\footnotetext{
${ }^{17}$ See Vivian Sobchak, The Address of the Eye: A Phenomenology of Film Experience (New Jersey: Princeton University Press, 1991) and Laura Marks, Touch: Sensuous Theory and Multisensory Media (University of Minnesota Press, Minneapolis, 2002).
} 
constituted in an always particular meaning." 18 Sexual or, for that matter racial difference plays an important part in the way we perceive the world because of our embodied position in the world and in relation to other people. She turns towards "a thick and radical description" of experience and, like Marks, she defines the potential of vision to create meaning through a dialectic process between perception and representation. ${ }^{19}$ Cinema uses modes of embodied existence as "the vehicle, the stuff of its language."20 The cinematic representation of duality of the body as both subject and object informs my approach to the filmmakers analyzed in this dissertation.

The challenge Sobchack and Marks bring to the supremacy of the visual model based on psychoanalytic explanations is useful for my analysis of the minute bodily practices portrayed in the films analyzed in this dissertation. Moreover, their contribution to film theory is a move away from a predominantly visual framework to one that takes into account the repressed aspects of sound, voice and bodily gestures in cinema as well as the engagement of spectators' other senses besides the visual. They see films as taking place in the world and touching us in a profound way. I will focus on a phenomenological consideration of the body in cinema, also keeping in focus the power played by visual technologies. It is interesting to note that few of the theorists problematize the diverging aspects of cinema as an entertaining medium (that aims to produce pleasure) or as a political medium (that aims to inform and interrogate). Most of the feminist theory from Mulvey to Williams focuses on the former aspect of cinema. The modes of visuality produced by the apparatus of cinema are not only objectifying, especially when we think of cinema as a medium that combines the visual and the aural, engaging various means of perception. Although

\footnotetext{
${ }^{18}$ Sobchack, Address of the Eye, 40.

${ }^{19}$ Ibid., Xv.

${ }^{20}$ Ibid., 4.
} 
the visual apparatus does support forms of power, it also offers possibilities of viewing that do not rely on power structures.

E. Ann Kaplan outlined the differences between the look and the gaze, an idea crucial for my approach to the feminism of Japanese male directors. According to her distinction, looking is mutual, a relation between or among people while gaze is a "one way subjective vision" guided by desire and anxiety. ${ }^{21}$ The gaze is dominating the other and refusing his/her alterity while the look is an act of holding in mutual esteem, of respect and care. This duality does not condemn cinema to a unilateral technology of male, white, Western gaze, allowing for a dimension of communication and mutuality. These discourses shift the feminist approach to cinema from an analysis of power to an analysis of ethics.

The focus on the body and perception in the study of cinema leads us to Thomas Elsaesser's insight that film seems to leave behind its function as a "medium" in order to become a "life form," a change that "would demand from film theory, next to a new epistemology, also a new ontology." 22 Cinema influences our way of being in the world and the main task of this dissertation is to highlight the ways in which the cinematic medium in the 1960s Japan entailed an ethical negotiation of the male directors' gender power. As the authors of the book Film and Ethics (2010) have shown, "while there is no established body of theory that might be described as 'ethical gaze theory,' the idea that ethics is an optics through which we habitually view and conceptualize is a persuasive one." ${ }^{23}$ Ethics involves an encounter with alterity that disrupts the self's illusory position of omnipotence or the power of the

\footnotetext{
${ }^{21}$ Kaplan, Looking for the Other, xvi.

${ }_{22}$ Thomas Elsaesser, Film Theory; An Introduction Through the Senses (New York, Routledge, 2010), 12 .

${ }^{23}$ Downing and Saxton, Film and Ethics, 2.
} 
gaze as a gendered mechanism of oppression. All filmmaking takes place in an ethical context, since cinematic representation engages in both desire and responsibility, a duality I will follow closely in my analyses of the films. This approach is even more salient in the New Wave context where many filmmakers moved away from the constraints of the studio system, articulating new cinematic forms and styles that explored the duality of cinema as a technology of pleasure and one of knowledge (including self-knowledge). Imamura, Yoshida and Hani were also documentarists and film theorists who grappled with ethical questions regarding the camera's ontological interventions.

All three branches of theories that highlight the cinema as a medium of representation that involves relationships between embodied subjectivities are useful for my approach to the films of the New Wave Japanese directors. Relying on Sobchack's insight that meaning and perception are dependent on our embodied experience I will analyze the representation of gendered body politics in the films structured by the filmmakers' style and approach to filmmaking. This analysis cannot be performed without attention to the power dynamics between male directors and the filmed women, which reflect larger gender hierarchies in postwar Japan. In my analysis of the films I will locate the female bodies as objects and subjects within the existential practices represented by the films, focusing more closely on their sexual objectification. Both in terms of content and technique I aim to explore the power dynamics inherent in gender and sexual relationships. These films portray various social norms that reinforce the transfer of women's ownership of their bodies to heteropatriarchal institutions. They follow the life stories of women against the background of Japan's postwar history revealing a fragmented embodied time that sometimes runs counter to Japan's official history. My reading of the films will offer 
access to a female embodied history that has long been placed in the shadow of official versions of history, politicizing sexuality as the locus of the most emphatic patriarchal disciplining of the female body. The female body is sexualized by a wide range of cultural institutions including cinema as a medium of visual representation. It is for this reason that my approach to the cinematic bodies of women in this dissertation uses the phenomenological minute exploration of bodies in cultural contexts without abandoning the political relevance of power analysis. 
Chapter Two. Rituals of Disciplining the Female Body: Prostitution and Rape in Imamura Shōhei's Insect Woman (Nippon konchüki, 1963) and Intentions of Murder (Akai satsui, 1964)

An essential part of the situation of being a women is that of living the ever present possibility that one will be gazed upon as a mere body, as shape and flesh that presents itself as the potential object of another subjects intentions and manipulations, rather that as a living manifestation of action and intention.'

In this chapter I will consider Imamura Shōhei's two fiction films, Insect Woman (1963) and Intentions of Murder (1964) analyzing the dialectical relationship between female subjectivity and the historical institutions of rural female exchange, feudal family and the prostitution system. My approach will posit the body as the interface between selves and cultural practices, using feminist theory and Japan's historical and cultural specificity to rework the Foucauldian framework of the body's inscription by power. Female resistance to the inscription of the body by social norms is represented by Imamura as resilience. The second aim of this chapter is to outline and critique ethical strategies employed by the director in his desire to make space for the marginalized women's voices and their bodily experiences within the national discourse. I will argue that he critiques cinema as an institution that objectifies the female body using it instead as an anthropological tool that constructs knowledge about women.

In the context of the New Wave, Imamura followed the same career path as Yoshida and Ōshima. He moved from Shochiku to Nikkatsu in 1954, where he worked until 1966 when he established his own company, called Imamura Productions. ${ }^{2}$ One aspect that relates Imamura to Yoshida and Hani is the exploration

\footnotetext{
'Iris Marion Young, On Female Body Experience: 'Throwing Like a Girl' and Other Essays (Oxford: Oxford University Press 2005), 66.

' Imamura Shōhei, Eiga wa kyōki no tabi de aru: watashi no rekishi-sho. [Film Is a Journey into Madness: a Personal History] (Tokyo: Nihon keisai shinbun-sha, 2004), 125.
} 
of the political dimension of bodies and the configuration of sexuality in postwar Japan. He shares with them an interest in women's experiences, portraying the struggles between women's subjectivities and cultural institutions that pin them down to their reproductive or sexualized bodies. Despite these resemblances, there are also important differences. While Yoshida portrays the relationship between sexuality, love and freedom of intellectual elites using avant-garde cinematic means, Imamura focuses on marginalized people from rural areas or low caste groups employing cinema as an anthropological method for understanding people's interaction with their environment. Despite his allegiance to realism as an anthropological method, Imamura also uses avant-garde tropes such as the freeze frames that transform the camera into a microscope for studying human emotion.

Imamura is interested in sexuality as a vital force of the individual that clashes with social and cultural constraints. As he has famously declared, "I am interested in the relationship between the lower part of the human body and the lower part of the social structure. ${ }^{3}$ The pursuit of this relationship has important political outcomes for the representation of women, who are bound by social norms that govern their sexuality and define them according to the social function of their bodies. For Imamura, Japanese identity is fractured along binary oppositions between modernity and native tradition, urbanity and rural life, repression and instincts. Unlike his contemporaries who look more to the West as their model, he searches for alternatives to the national character, which he finds in kiso shakai, defined by Katori Shunsuke as, "people at the bottom of social hierarchy in the provinces, the country, out-of-the-

\footnotetext{
${ }^{3}$ Quoted in Yamada Koichi, "Les Cochons et les Dieux: Imamura Shōhei," [Pigs and Gods, Imamura Shōhei], In Cahiers du Cinema, No.166 (Mai-Juin 1965), 31.
} 
way places and remote outlying regions as well as criminals." ${ }^{4}$ He contests what he calls "the official" version of Japan by focusing on a pre-modern society anchored in animistic beliefs. Donald Richie suggests that Imamura reveals the "true" version of Japan, which is not the official image shown to the rest of the world and consensually approved by society, an image Ozu Yasujirō has produced throughout most of his films. This version is "natural," "uncivilized" and instinctual. ${ }^{5}$ All these adjectives may pull an alarm sound of essentialism for the cultural theorist. On one hand Imamura brings to the forefront the experiences of marginalized women but at the same time by placing them in opposition to the national discourse he falls in the anthropological trap of essentialization. However, he does not fail to reveal in his films how nature and instinct are implicated in social/historical relations despite his own belief in the existence of a natural, instinctual realm beyond history.

Unlike Ozu who emphasized continuity and permanence, Imamura "seeks out the pressure points in Japanese culture and history-moments of ruptures...sites of institutional instability like the red light district catering to American soldiers. ${ }^{66}$ Even though he creates dualities throughout his entire career, between nation and individual, instinctual and social, rural and urban, tradition and modernity, his scientific spirit allows him to observe the problematic nature of both sides of the binary. Imamura was convinced "that cinema could provide a scientific tool to investigate Japanese humanity." In an interview with Satō Tadao, Imamura stated that unlike Ishihara Yujirō, who portrayed in his films "the superficial pleasantness" of sexual relationships, he breaks film conventions in order to "explore the nature of

\footnotetext{
${ }^{+}$Katori Shunsuke, Imamura Shōhei densetsu [The Legend of Imamura Shōhei] (Tokyo: Kawade Shoboshinahsa, 2004), 9.

${ }^{5}$ Donald Richie, "Notes for a Study on Shōhei Imamura," In Shōhei Imamura, ed. James Quandt (Toronto: Toronto International Film Festival Group, 1997), 7-45, 8.

${ }^{6}$ Dave Kehr, "The Last Rising Sun," In Shōhei Imamura, ed. James Quandt (Toronto: Toronto International Film Festival Group, 1997), 69-89, 70.

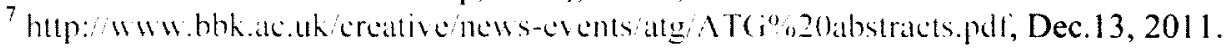


human beings." ${ }^{, 8}$ He thus distances himself from the conventional studio system cinema meant to entertain spectators and insure revenue, with a cinema meant to reveal and document marginal worlds lacking representation within the national discourse. This aspect of his anthropological impulse brings him close to the feminist strategy of articulating female experiences marginalized from mainstream practices and discourses. Imamura was in conflict with the studio executives over various issues, such as his anti-American sentiment in Pigs and Battleships (Buta to gunkan, 1961), and the lack of commercial success of both Insect Woman and Intentions of Murder. As he himself declared, his films "frightened Nikkatsu" and he felt too constrained by the regulations of the studio, whereupon he started producing independent films. ${ }^{9}$ Similar to the case of other filmmakers in this period, the studios' business regulations were too confining and did not allow for personal exploration. They pursue cinema not only as a career or even vocation but also as a tool for exploring troubling cultural and personal issues. This degree of freedom and subjective involvement in the process of filmmaking had as a result a greater degree of experimentation with cinematic technology.

The two Imamura's films I will analyze in this chapter were made at Nikkatsu studios. They portray the disciplining of the female body through the institutional intersection of prostitution, feudal family and the supremacy of male desire, representing the body as a battleground between women's subjectivities and social norms. My approach to these films is informed by Sara Ahmed's phenomenological insights about bodies as being always oriented towards other bodies and towards the spaces they inhabit. These spaces "are like a second skin that unfolds into the folds of

\footnotetext{
${ }^{8}$ Imamura Shöhei interview with Satō Tadao on the Criterion collection DVD.

9 Max Tessier, "Shōhei Imamura interview," In Shōhei Imamura, ed. James Quandt (Toronto: Toronto International Film Festival Group, 1997) 57-69, 64.
} 
the body," and they produce forms of subjectivities dependent on their context. ${ }^{10}$ The interaction of female bodies with their context acts as a second skin that constructs a particular kind of interior, a form of resisting subjectivity impressed upon by social norms but not completely. In the following part I will analyze Imamura's desire to capture the alterity of women by exploring their interaction with their environment and the ethical problems inherent to the cinematic anthropological impulse.

\section{Film, Power and Anthropology}

When asked by Nakata Toichi about the research he did for his films, Imamura mentioned his desire to understand people. He first tried to gain a sociological perspective and when that was too limiting, he turned to the study of social anthropology, an approach lying at the origin of Insect Woman and Intentions of Murder. "Of course social anthropology does not provide all the answers...All scientific approaches have their limits. Above and beyond everything else, working as an artist means having a limitless curiosity about human beings." 11 This position informs my analysis of his anthropological views of filmmaking as the intertwining of science (anthropology) and artistic curiosity. Imamura expressed many times his allegiance to the honesty and instinctive nature of marginal people, especially women. Although he came from a well-off family, after the war he faced personal hardship and was looked after by prostitutes and bar hostesses." 12 This personal experience pervades not only his values but also the desire to portray in film aspects of these women's lives. We can observe here the same ambivalence that has characterized Mizoguchi Kenji's work. Both directors frequented prostitutes, were occasionally

\footnotetext{
${ }^{10}$ Sara Ahmed, Queer Phenomenology; Orientations, Objects, Others (Durham: Duke University Press Books, 2006), 9.

"Toichi Nakata, "Shōhei Imamura Interview," In Shöhei Imamura, ed. James Quandt (Toronto: Toronto International Film Festival Group, 1997), 107-125, 116.

12 Ibid., 117.
} 
supported by them and they made films indicting prostitution and exposing women's suffering, each one in a different way. ${ }^{13}$

There are two characteristics I will analyze concerning Imamura's anthropological view of cinema: his interest in marginal groups excluded from the official national discourse and his approach to cinema as a scientific tool for understanding how people interact with their environment. His lifelong pursuit of characters from marginalized, rural society relates him to the famous Japanese ethnographer, Yanagita Kunio, an important source of inspiration for Imamura. Yanagita wanted to record old Japanese myths and folktales before they disappeared with the advent of modernization. One of his most famous concepts is the jomin (the common person), whose experience seems far removed from national discourse. ${ }^{14}$ Isolde Standish notes a correspondence between Yanagita's efforts to counteract the narrative of the Meiji state with representations of the common folk and Imamura's effort to counter the Shochiku style films about lower classes with stories about people at the bottom of social hierarchy. ${ }^{15}$ Both Yanagita and Imamura ground the marginal, rural life in authenticity and truth regarding national history as a constructed discourse. They create the vision of parallel worlds within the Japanese nation state and they try to document and make visible what has been marginalized by national history. However, unlike Yanagita, Imamura does not dwell too much on nostalgia for the loss of traditional ways of life and the destruction of affective community ties, preferring instead the detached observation associated with criticism or irony. Although Imamura pays allegiance to the objective, non-interventionist camera, his

\footnotetext{
${ }^{13}$ For a detailed analysis of Mizoguchi's works see Mark LeFanu, Mizoguchi and Japan (London: British Film Institute, 2008).

${ }^{14}$ Bill Mihalopoulos, "Becoming Insects: Imamura Shōhei and the Entomology of Modenity," In The Power of Memory in Modern Japan, eds. Sven Saaler and Wolfgang Schwentker (Boston: Brill/Global Oriental, 2008), 277-290, 278.

${ }^{15}$ Isolde Standish, Politics, Porn and Protest: Japanese Avant-Garde Cinema in the 1960s and 1970s (London: Continuum, 2011), 84.
} 
subjective presence is felt through cinematic techniques of symbolism, freeze frames and irony.

Both the ethnographer and the filmmaker counteract the discourse of homogenous nation placing the essence of Japanese identity in the marginalized realm of rural or oppressed groups. "The realm of visible power and authority featured in history textbooks where all its cultural artifacts and monuments were proudly displayed in the iconic accounts of national heroes, the wars they fought and the institutions they created. The other realm was the unseen domain of the agricultural village which was outside the purview of central authority and as a result, unregistered in the history of the nation state."16 Both Sadako (Harukawa Masumi), the heroine of Intentions of Murder and Tome (Hidari Sachiko) in Insect Woman are subordinated not only through their gender but also through their low class and rural origin, revealing Japan as a stratified society divided along a rigid hierarchic system. This doubling or fracture of the homogenizing concept of nation is also a subject that informs Imamura's documentaries about women, the subject of the next chapter. ${ }^{17}$

The second characteristic of Imamura's anthropological approach is his desire to understand the nature of real human beings through a detailed and objective cinematic representation of their interaction with the environment. Although Imamura manifests a desire for objectivity and detachment, he is not an impartial observer. He is an avid researcher, gathering meticulous information from real people about the characters he wants to describe in films. In the case of Insect Woman, there are two founding stories for the film. The first one is the story of Ōshima, a waitress in the

\footnotetext{
${ }^{16}$ Mihalopoulos, “Becoming Insects,” 279.

${ }^{17}$ Although the marginal Japan is essentialized as the "real," the true Japan, this perspective echoes the feminist perspective, that there is world belonging to women, which is struggling to articulate itself but which will always run counter to dominating discourses.
} 
white light district (non-professional prostitutes), an interesting woman, full of vitality and stamina. Imamura would repeatedly meet with her and fill three notebooks with her non-coherent life story trying to find the connection among events. We can note two conflicting positions of the scriptwriter: as curious and interested listener/researcher and in the power position as male client and the owner of her story. He finds the connection among the incoherent events described by Ōshima in a moment of inspiration, which is the second founding story for the film.

The inspiration for the title of the film came to him as he noticed an insect "incessantly circling" his ashtray while he was drinking sake. He parallels the woman's situation to that of the insect and his position becomes that of an entomologist who tries to understand why the insect continued to try to climb over an obstacle despite the continuous failure to overcome it. ${ }^{18}$ This moment explains the title of the film (Nippon konchüki -- Japanese Entomology) and has led some critics to call Imamura an "entomologist." woman as insect and man as observer and it reinforces the scientific implications of the anthropologist/entomologist as a detached and objective observer. However, I also find in this metaphor proof of his effort to understand the repetitive cycle of women's subordinate social position and bodily work that traps them in inescapable situations. "There I emphasized more the terrifying fact that a woman's energy does not do much to change her situation, but instead it makes her turn in circles, such that she remains what a woman was and still is in Japanese society: submissive, dominated and sentimental." ${ }^{, 20}$ As problematic as Imamura's patronizing tone is, this quote reveals an

\footnotetext{
${ }^{18}$ This is a metaphor also present in Hiroshi Teshigahara's film, The Woman in the Dunes (1964) but with different implications.

${ }^{19}$ See Kehr, "The Last Rising Sun," Satō, Currents in Japanese Cinema and Mihalopoulos, "Becoming Insects."

${ }^{20}$ Tessier, "Shōhei Imamura Interview," 61.
} 
important aspect appearing in his films: the multiple forms of oppression faced by rural Japanese women discipline their bodies producing subjectivities with increased awareness of what it means to be material objects. Their second skin is that enforced upon them by layers of intersecting oppressive forces. Their orientation in the social space is dominated by the objectification of their bodies. If the films were merely representing female objectification, they might be criticized for extending gender power through representation but it can be argued that to a certain extent, Imamura deconstructs objectification by showing its mechanism of producing certain forms of subjectivity.

The metaphor of entrapment and wasted effort frames the structure of the film, which starts with a shot of an insect trying to climb over an obstacle and ends with Tome grudgingly climbing the mountain in order to return to her village. The same metaphor appears in Intentions of Murder in the framing of the heroine together with a mouse running on a treadmill. The 150 minutes long study of the issues surrounding a woman's rape also reflects Imamura's anthropological inclinations in the detailed analysis of female resilience and strength clashing with the restrictions and oppressions of Japan's stratified society. The metaphor of the insect in Insect Woman is paralleled in Intentions of Murder by an all too obvious metaphor of caged mice. While I do find both metaphors relevant in symbolizing the subordinated female social place, they are problematic for the associations Imamura makes between women and the realm of nature. Ironically, the same anthropological trait that characterizes Imamura as a feminist, is also one that problematically defines women as closer to nature.

Female bodies have long been regarded as closer to nature because of their ability to bear children and their supposedly more intense emotional life. Imamura too 
makes this connection by presenting three generations of women and the ways in which they ensure the continuity of life through their bodies. He is also set on revealing women's instinctual, natural side through their bodies and emotions. However both films confront the historical norms surrounding sexuality, pregnancy and the birth of children that place women under the domination of oppressive social systems. Imamura's anthropological inclinations are best exemplified in this film both as a method of representing the character in relationship to her cultural context and as a manifestation of his discursive power (the one holding the camera) to acquire and produce knowledge about women. His research, interviews and interest in the stories of women reveal Imamura's ethical negotiation of his power as a director and his discursive responsibility.

Although Imamura's desire is to portray women's instinctual strength and resilience, the film is also representing the various forms of power that discipline their bodies. The narrow focus on women's wasted energy in Imamura's above quote overlooks the even more terrifying fact that women's oppression reproduces itself along various historical changes by limiting women to the sexual or reproductive potential of their bodies. His approach can be considered feminist not for his fascination with female resilience but for his exploration of the construction of femininity through the discipline of the body. Unlike Yoshida and Hani's selfreflexive concern with the ethical implications of filmmaking manifested through the focus on subjectivity, Imamura's ethical engagement is close to a scientific commitment to knowledge about women.

Scholars like Robert Stam and Ella Shohat have noted the desire to tame and colonize implicated in the desire to know in general, critiquing the visual inclinations of anthropology to "give credibility (and) transform the obscure mappa mundi into a 
familiar, knowable world." 21 Imamura's camera displays the woman's story transforming it into a coherent world adjusted to his own beliefs and perceptions. Stam and Shohat are right to criticize both the impulse to know and the impulse to record with a camera because of anthropology's participation in colonizing efforts and because of its allegiance to telling the truth about other cultures. I agree with their suspicion but I argue further that the desire to know also implies the desire to go beyond one's boundaries as an act of ethical engagement and attention.

Imamura believes in cinema and anthropology as methods that bring us closer to marginalized or oppressed people but he cannot escape his subjective power position versus these people. He can be critically called a "feminist" with the acknowledgment of his multiple power positioning that at times he self-reflexively admits: as a client of the bar where the woman works, as the filmmaker who possesses the story having the freedom to decipher it and turn it into visual images, and as a detached, scientific observer who can objectively grasp the truth about women. Despite the problems raised by his enactment of the power of scientific gaze in the representation of women, his films show a commitment to portray women's alterity. The film does not sexualize the female body for visual pleasure but it shows instead how women's humanity is denied because of the objectification of their bodies. Imamura's films about women portray female bodies as both subjects and objects of desire, contextualizing them and allowing onscreen space for their subjectivity and emotions.

\footnotetext{
${ }^{21}$ Robert Stam and Ella Shohat, Unthinking Eurocentrism: Multiculturalism and the Media (London: Routledge, 1994), 106.
} 
The curiosity about real women's lives and his avid research, the interest in marginal groups and in the interaction between individuals and their social context place Imamura's cinema along anthropological lines. This approach can be criticized for its allegiance to the power of disinterested, objective observation epitomized in the metaphor of entomology. Being in the possession of the camera means for him being in the possession of knowledge about women, especially of their allegedly unchanging nature. The merit of this approach is that of revealing the contextual cultural constraints of becoming a woman both in the Japanese rural and in the urban context and thus exposing (maybe against Imamura's own beliefs) not women's unchanging nature but the intersection of historical oppressive forces that discipline female bodies. I argue that his approach can be considered feminist if we follow Mary Ann Doane's concepts of feminism as the critique of the naturalization of the female body and the analysis of the "syntax which constitutes the female body as a term." $" 22$ it is the focus on construction of female subjectivity through the interaction between institutional power and bodies that marks Imamura's strategy as feminist, rather than the portrayal of female strength or female suffering. In the following part I will focus on Insect Woman, analyzing the moments of interaction between the heroine's body and the institutions of rural female exchange, feudal family, prostitution and rape as rituals of disciplining the female body.

\section{Insect Woman -The Exchange Value of the Female Body}

Insect Woman portrays the story of Tome, daughter of a poor peasant family in

Honshu who lives through Japan's tumultuous historical change between the late 1918 and 1960s. The story of the film has its origins in the life story of Ōshima, a woman Imamura encountered in a bar. The heroine tries to break free from the poverty of her

\footnotetext{
22 Mary Ann Doane, "Woman's Stake: Filming the Female Body," In Feminism and Film Theory, ed. Constance Penley (New York: Routledge, 1988), 216-228, 226.
} 
family by working at a textile mill and later in the city as a maid but she ends up working as a prostitute and later as the madam of a house of prostitutes. She appropriates the norms that she defied along her life perpetuating the ruthlessness she has encountered. Her life is portrayed against Japan's modernization, imperialist war, defeat and American Occupation as a continuous struggle for survival against changing oppressive circumstances.

In my analysis of the film I will focus on the disciplining of the female body by institutional forms of power. I will analyze the rituals that discipline her body from desire for pleasure and self-determination to pain and alienation. Drawing on Imamura's interest in anthropology I use the word "rituals" to explore the various moments that punctuate an innocent country girl's transformation into a prostitute and later a ruthless exploiter of other women. Like many other New Wave filmmakers in Japan, Imamura is interested in sexuality and identity but rather than portraying the female body as a site of visual pleasure, he describes it as a site of struggle between patriarchal institutions and women's subjectivity. The film represents multiple marginalized worlds: the bodily and affective experiences of poor, rural women in the context of Japan's modernization.

The first shot of the film is a close up of an insect struggling to climb over an obstacle and constantly falling, accompanied by the soundtrack of a haunting nursery song that will repeat in various instances in the film as the disciplining ritual of threatening the baby to sleep. "If you do not sleep the mice will scamper over you..." The title, Nippon konchüki (Japanese Entomology) appears against the still frame of the struggling insect. 


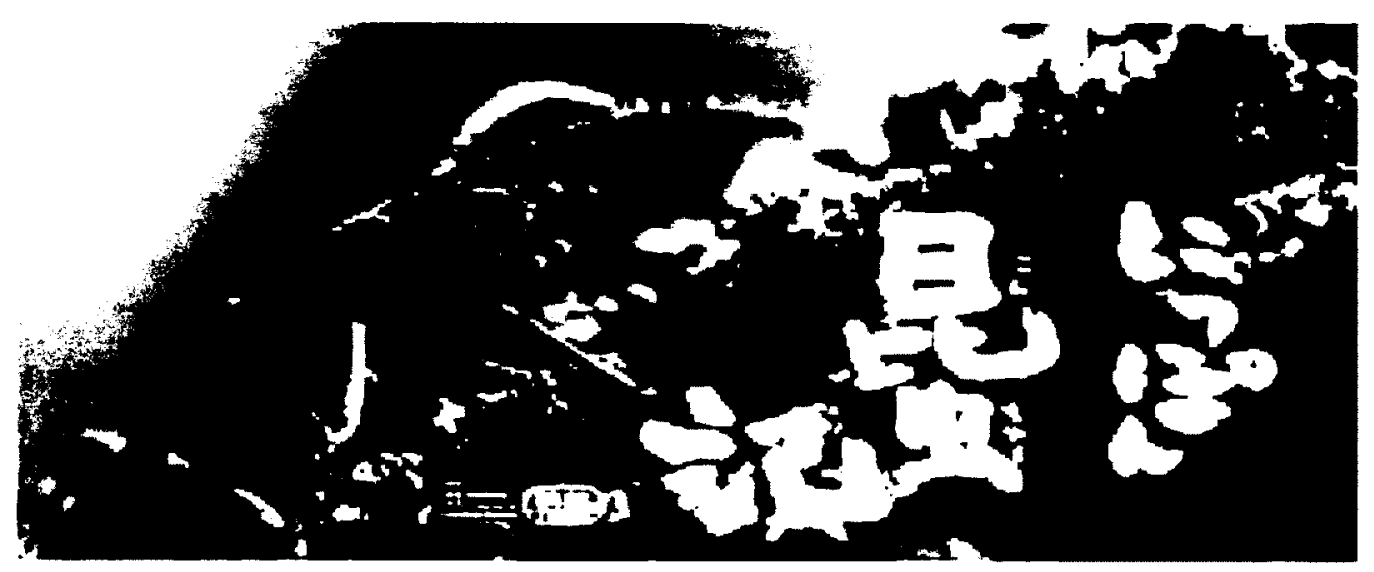

The final shot parallels the first shot of the insect with the heroine grudgingly climbing up a hill to return to her village, her body rendered small and insignificant by the high rising mountains around her. Imamura retells the woman's story metaphorically setting it up as the scientific pursuit of essences. In this case, the essence is the woman's resilience and survival skill. However, Imamura's preoccupation with essences is paradoxically paralleled by a relentless exploration of what is social and cultural. We can admire female resilience as an essentialized feminine trait but instead we can focus on the oppressive circumstances that discipline women into being resilient. In the following part I will consider the cinematic means of representation Imamura uses to create an intimate relationship between cinema and reality. What are the film techniques used to represent the female body as a term constituted by disciplining institutions and how does the camera counter or participate into its alienation? 
The last shots of the heroine returning to her village parallel the first shots of an insect unable to climb an obstacle, a visual metaphor for Tome's inability to transcend her oppression.

The Female Body in Japan's Rural and Urban Context: Sexual Freedom Versus Alienation?

The life of the heroine in this film is marked by her spatial and temporal shift from the rural to urban space, from the innocence of youth to the alienation of middle age, in conjunction with Japan's historical transformation. Bill Mihalopoulos draws an interesting parallel between Tome's psychological transformation and the history of Japan's encounter with modernity. "In terms of collective experience the film tells how the rural poor have been doubly colonized; by the myths imposed on them in the name of the emperor and by the forces of the market unleashed and nurtured by American Occupation." 23 Satō Tadao too thinks that ordinary women realistically mirrored the conditions of the masses since they seldom rose to positions of leadership or because members of the ruling class." 24 Both scholars read Tome as representative of Japan's historical conditions but this reading tells us more about Japan than about the ways in which women embodied Japan's history. My reading goes along the same lines but it changes the perspective: instead of extending the female character metaphorically to a group or even the nation, I would like to explore the microcosm of the female embodiment of Japan's history. What does this perspective teach us about the relationship between bodies and national history? Tome's story reveals not only the fracturing of the nation into official/national and marginal/rural but an intersection of multiple levels of oppression and marginalization, with poor village women at the bottom. Her life story reveals the process of transformation from Japan's indigenous

\footnotetext{
${ }^{23}$ Mihalopoulos, "Becoming Insects," 278.

${ }^{24}$ Satō, Currents in Japanese Cinema, 81-82.
} 
traditions to modernity, from village to city and from community based affective relations to the alienating rules of the market.

Both the poverty of rural life and the alienating commodification of urban life create systems that regulate female sexuality. I agree with Mihalopoulos when he refers to the village in the film as a space for the "spontaneous enjoyment of life," a vital primitivism exemplified by the strong, incestuous attachment between Tome and Chuji, her half-wit father. However, the village is also a source of helplessness and despair portrayed in the touching scene where Tome is forcibly sent to be maid and concubine to the son of the family that rented them a plot of land. The rural poor who seem the members the most removed from history bear its heaviest burden. Imamura regards the village as representative of a universal mode of life forming the core of what it means to be Japanese. The village is opposed to the visible, recorded world of power revealing Japan as a split nation. One cannot overlook the gendered dimension of this split, where the agricultural village with its common people is female while the world of power and authority is male. Imamura values the village and the female because he regards them as the emotional and instinctual backbone of Japan.

It seems to me that Imamura's critics more than he himself regard the village with nostalgia for the lost paradise and village women as bearers of female sexuality free from the taboos of modern society. Isolde Standish argues that the village is the space of an "exaggerated sexual energy, which spills over into quasi-incestual relationships." 25 Tome is curious about sexuality and she enjoys her attachment to her father coming from the proximity of their bodies. However, even in the rural context her sexuality is channeled from the manifestation of her own desires into social

\footnotetext{
${ }^{25}$ Standish, Politics, Porn and Protest, 87.
} 
relationships based on the objectification of her body. ${ }^{26}$ Both the poverty of rural life and the alienating commodification of urban life create systems that objectify the female body. In order to pay back the debt of her family Tome is sent to work for the Honda family, a situation she grudgingly accepts promising herself she would not become the concubine of the family's son. I will analyze three scenes in the village that portray rituals of enforced obedience meant to discipline Tome's body.

The first scene describes her forced departure to the Honda family. The lowkey lighting and the suggestion of a cold winter highlight Tome's sense of despair and alienation from her own family. The mise-en-scène is of a family dinner, which, instead of evoking the image of a protecting hearth is full of ominous signs, like the sarcastic laugh of Tome's grandmother. The women in the family persuade Tome that she has to leave in order to save the family, but she refuses, hoping her father will intervene. The next shot places Tome in the foreground of the image and the men who came to take her to the Honda family in the background. It is the first instance in the film that introduces a correspondence between Tome and Japan, albeit an ironic one. The men talk about the fall of Singapore, a euphoric moment in the Japanese state marking the triumph of Japanese colonialism, laughing that "Tome too will fall tonight." The father is away from home but he returns when they are about to leave. In a burst of fury he starts chasing and beating his wife in a scene overflowing with strong emotions. The scene ends with the implacable voice-over of the old woman highlighting a freeze frame of Chūjii's helpless violence. "You can't fight the will of the gods." The first ritual of disciplining Tome's body is her forced evacuation from her family manifested as the will of the gods and of the family's women but in fact the result of poverty and the feudal system of land property.

\footnotetext{
${ }^{26}$ Her desires are incestuous, a trait which reveals Imamura's preoccupation with the trope of incest as a symbol for the enclosed and stable traditional, rural life.
} 


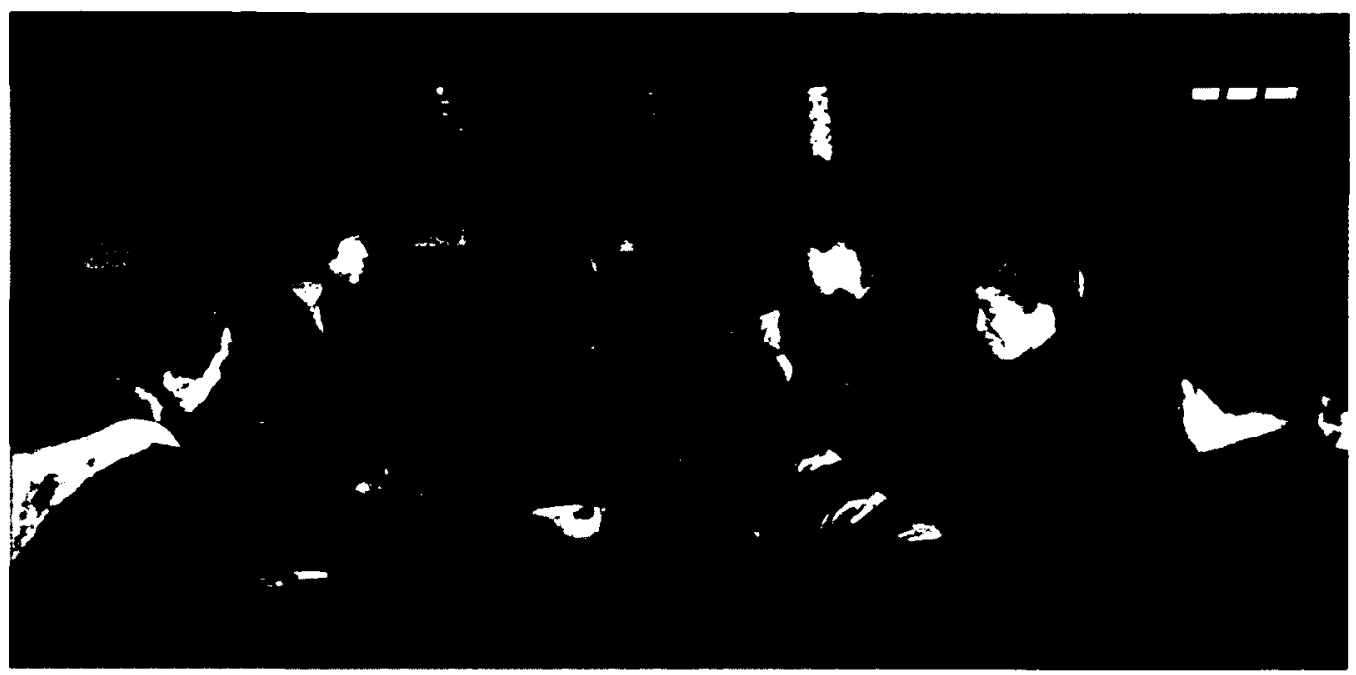

The family dinner evokes an ominous, oppressive atmosphere and despite Tome's protests, her maternal relatives force her to leave as a labor hand to a landlord.

The second scene shows rape as another form of violence meant to discipline Tome's subjectivity through the forced possession of her body. The low-key lighting reveals the action more through sound than through visual means. Frustrated with the cold and the hard labor he has to do, the son wants to have sex with Tome, who adamantly refuses. A fight ensues where she cries and tries to run but the son breaks her resistance both physically and through rational coercion, telling her that she must do her part for the country since he might be soon drafted to war. Despite her initial fight and screams, the soundtrack continues with her panting "Papa! Papa" that suggests incestuous pleasure. The open door allows for a great amount of light to come in contrasting with the inside darkness and a child appears and watches them. Hondas' son already has a family, who hates and despises Tome for the sexual act. The same idea of the woman being socially blamed for rape appears in Intentions of Murder. Male sexual desire inscribes the female body with sinful sexuality, all the more guilty if it ends in pregnancy.

The scene bears similarities with the rape scene in Intentions of Murder in the suggestion of final pleasure after adamant refusal. In both cases Imamura works along 
the pinku film pattern where women fall in love with their rapists but his portrayal suggests that sensual pleasure is only available to women within a context of forced coercion and submission. In other words, the sexual encounter bears the social gender construction based on the repression of female pleasure and the appropriation of the female body as a source of male pleasure. This technology of the body creates a context in which women will love the power that dominates them. Female sexual pleasure is possible via objectification and submission. The difference between Imamura's approach and pinku film is that he shows how the female body becomes objectified instead of relying on this pattern to create visual erotic pleasure.

The third instance of coercion is beautifully portrayed through a high angle camera showing Tome's body trapped in the snow, doing laundry by hand. She calls her mother and informs her that she cannot stay any longer at the Honda family. Her mother advises her to make good use of her body and win against the other mistress of Honda's son by becoming a wife and thus assuring a position in the family for herself. This shot suggests Tome's entrapment in her body. The lessons she learns early in life is that she is an object body to be used by her own family and by the men who are better off than her, lessons that she will put to use when she goes to the city. However, using her body to achieve the goal suggested by her mother proves risky business since she becomes pregnant before winning the son's favors and Chūji, her father beats the son for abusing her. As a result she comes back to her family pregnant and lonely, only increasing their frustration with poverty. 


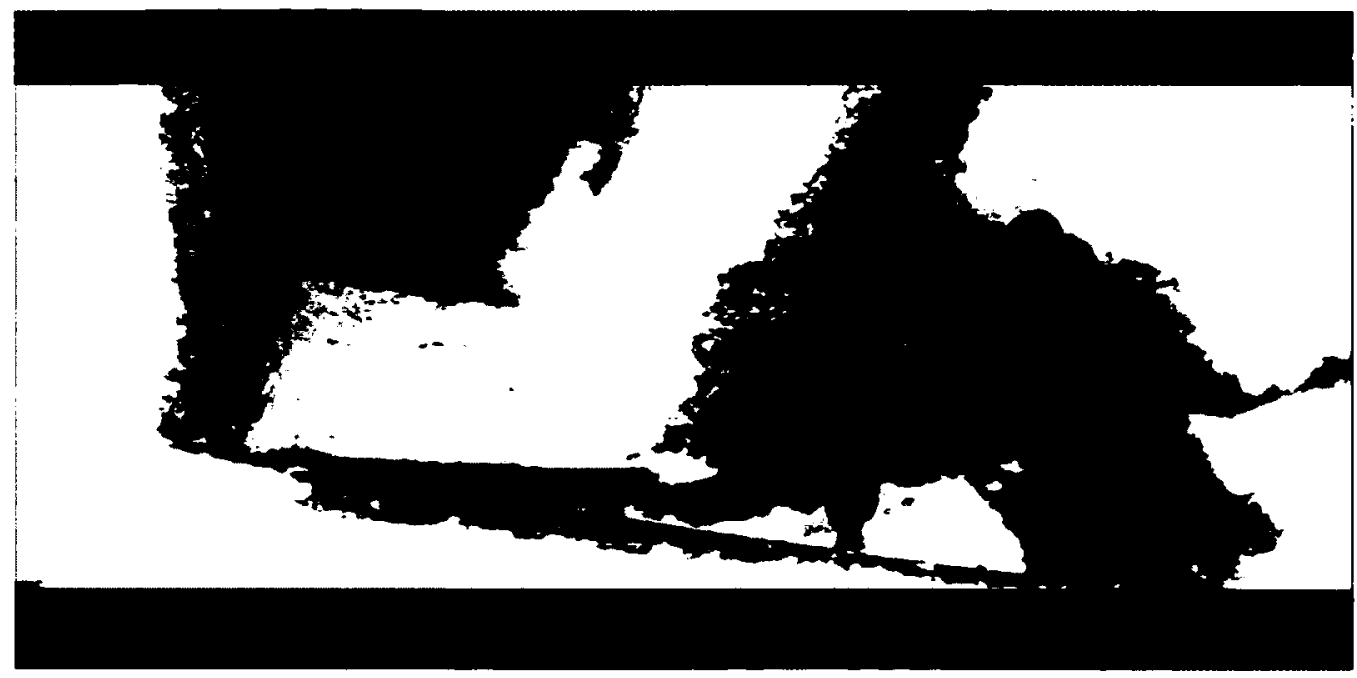

This high angle shot suggests Tome's entrapment not only in the space but also in her sexual body, when her mother advises her to become the landlord's mistress.

These three instances of entrapment and forced coercion are portrayed as rituals of disciplining the heroine's subjectivity in order to submit to the objectification of her body. Although it is true that Imamura values rural communities, I disagree with many critics' nostalgic reading of the Japanese village as an expression of primitive, free sexuality. For Tome the village is the space of genuine attachment but also the space that disciplines her sexuality towards goals other than her own pleasure or happiness. The forms of disciplining she encounters in the rural space are rituals of initiation into the even more alienating city life. The lessons she learns from the rituals of coercion portrayed in the film are that she must inhabit her body as an object that needs to conform to desires that are not her own. More specifically, her body remains on object of exchange despite her experience of historical change.

Whereas in the rural context Tome is defined in terms of the exchange value of her body, its ability to work, pleasure men and provide children (in the appropriate context), in the city Tome learns to use her body and other women's bodies as a commodity that can be exploited. The end of the war shows Tome working at a mill 
factory where she has a lover with whom she starts up a factory union. Through parallel editing Imamura introduces the second moment of ironic correspondence between Tome's body and the nation. While the emperor's speech is heard by the workers over the radio, Tome lies down with fever. Her lover brings her food and he wants to have sex. The close-up image of her face highlight her sadness and desolation both due to her illness and to the news of Japan's loss of war. Both the nation and the woman submit to an inescapable but undesired circumstance. Her lover breaks up with her when he becomes the manager of the mill, as a precaution against their experience of being union leaders. Her hopes for love and for decent work are crushed as she is fired from the mill and becomes a maid for a Japanese woman living with an American GI. She learns that she can have a decent social position only through men and she is thus again dependent on the ability of her body to respond to their desires.

The most poignant ritual of alienation happens with Tome's initiation into prostitution. She works as a maid in a house of prostitutes and one client raises complaints. In order to placate him, the madam of the house asks Tome to dress up in a kimono and take him some sake. There is a time ellipsis explained in the next shot. The madam is placed in the foreground in a medium close up image, dying her hair, while Tome sits with her head to the wall in the background left of the frame, a position suggesting restriction and entrapment. We are aware of Tome's emotion through the tone of her voice marked by subdued anger. "You violated my rights by locking me in. You never told me this was a brothel. It's outrageous. I thought I'd be safe here (since she met the madam in a religious group). You're turning hungry women into slaves." The frame arrangement suggests the madam's power over Tome, the power to commodify her body for men's pleasure but also the power to make 
Tome herself agree to this arrangement. She is justifying the existence of prostitution as a system of economic exchange where women can survive because men pay for their bodies. Finally, she cynically offers her the choice to leave or accept a part of the money she took from the client. Initially Tome refuses to take the money but she changes her mind and desperately clings to them. This construction of norms of power as second skin to the female characters is a trait that appears in both Imamura's films in the portrayal of the woman's initial refusal or struggle against objectification and her final acceptance.

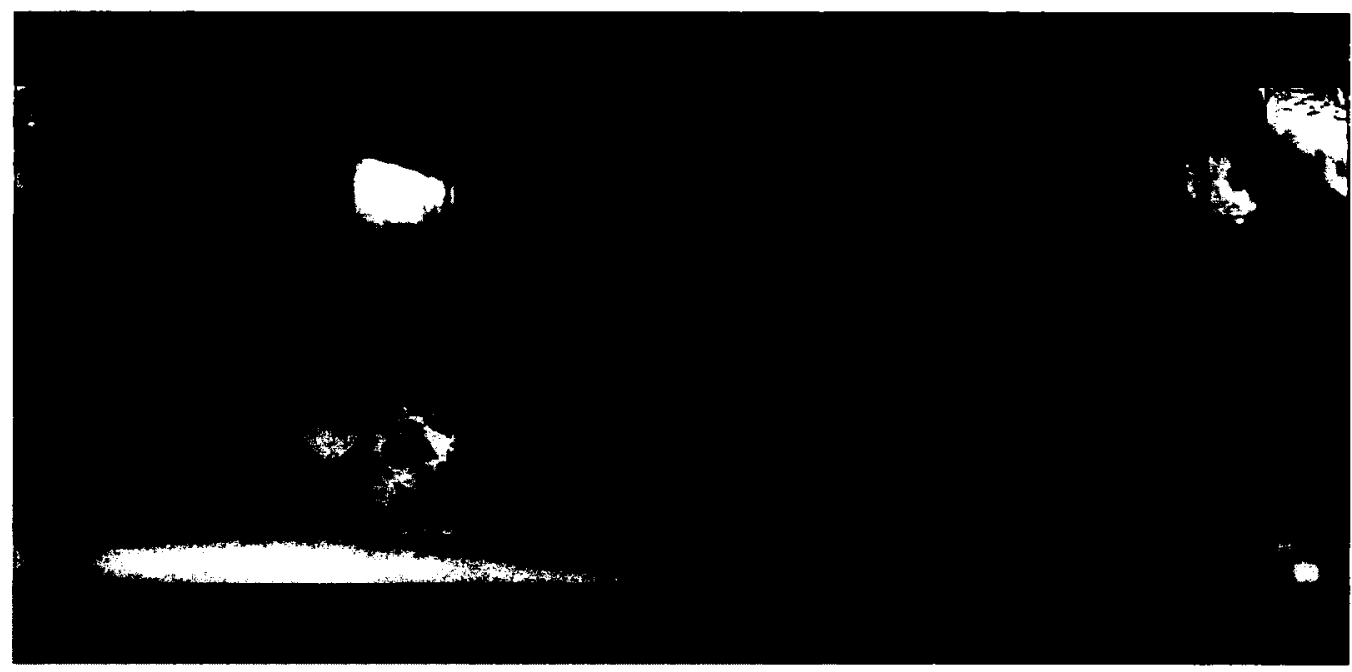

Tome's position in the left side of the frame, facing the wall indicates her rage and powerlessness while the close-up of Madame Suma reveals her cynicism and ruthlessness.

Her body used as an exchange object between families in the rural context is in the urban milieu a commodity equal in value to the sum of money it can be exchanged for, thus being robbed of its subjectivity. All she can hope for is a man's love, which, she painfully finds out, is not a reliable source of security. While she works for Madame Suma, she develops a relationship with her patron, Karasawa, which makes Tome happy for the first time in the city. He buys an apartment for her and she turns Madame Suma to the police, replacing her in the exploitation of other women in order to provide money for Karasawa. Through an ironic twist she does now all that she 
used to hate, proving that she has learned the ruthless lessons of the urban market. As Mihalopoulos states, "she loves the power that the alignment of capital and masculine values give her. “27 This period is one when she feels most empowered and happy but it is not one that lasts.

The third moment of learning the bitter lessons of being an object body is when she learns that Karasawa's love for her is dependent on the capacity of her body to smooth out his business relations. In a tightly closed framing we see a close-up of her face as she tests out Karasawa's love. He needs to bribe an important businessman from Fuji steel company and he does not find a proper girl to do it. When he asks her to go, she replies with a tense face doubly represented through a side mirror: "I'll go if it is OK with you." As he nods, her last hope is crushed and she cries out with bitterness. "You really don't care if I go." 28 The heavy rain of a typhoon expresses her emotion and she feels drops on her face from the ceiling, another device Imamura uses to deflect the melodramatic tension. Karasawa leaves her for her daughter later when she is in turn imprisoned for prostitution.

In the urban context Tome learns to use her sexuality strategically, through the objectification of her body and other women's bodies. The only time she has a relationship based on mutuality is when she has economic independence based ironically on her exploitation of other women. The idea that sexual love exists only in a context of independence forms the central theme of Yoshida's film, a subject I will analyze in the third chapter. In this film love is based on power relations as a precarious financial and emotional security that women long for and for which they bargain their bodies. The mutual exchange of love is represented in opposition to

\footnotetext{
${ }^{27}$ Mihalopoulos, "Becoming Insects," 286.
}

28 Ibid. 
prostitution but the final lesson Tome learns in the city is the inextricable link between the two. The intersection of gender and class oppression reduces women to the sexual potential of their bodies depriving them of a sense of self-determination. In the next part I will focus on prostitution as a form of survival through the relinquishing of the female body to an alienating exchange system.

\section{Prostitution and Alienation}

Unlike Suzuki Seijun's films about prostitutes made during the same period that eroticize their onscreen bodies, Imamura's film focuses on prostitution as a form of survival, revealing women's perspective. Jasper Sharp pointed out the influence Insect woman had on the pink genre, through its "daring depiction of sexuality, the underground world of the brothel, (and) scenes surrounding the American airbase."29 As I pointed out in the introduction, the film explores sexuality from a female point of view and its purpose is to inform and critique, rather than exploit it for pleasure. We are witnesses to the back stage of the prostitutes' world, a painful world in contrast to the façade of pleasure and glamour. This perspective is filled with irony and criticism epitomized by the scene of the virgins. A woman comes down the stairs looking for "virgins," bottles of blood that they use when required. Because they are frozen she asks the two women who cook in the kitchen to take her blood. She grows pale as they take out her blood while she chatters that for so much money she will give her blood too. They stop and instead look for a cat to provide them with the needed blood while the old cook exclaims. "Men are such fools. What is so special about virgins?" This scene emphasizes women's bodily pain exchanged for male pleasure in a context of unequal economic relationships.

${ }^{29}$ Sharp, Behind the Pink Curtain, 54-55. 
Tome's anger at Madam Suma's exploitation of her sexuality is met with a cynical explanation of the money value of her body "A woman over thirty won't find the food and shelter you have here." As Mihalopoulos has suggested, there is a close relationship between the capitalist system and prostitution. "Prostitution, like money, reduces all social relations to the generic content of exchange." ${ }^{30}$ Deprived of a social and economic position that would allow them to enter the market world as subjects, women rely on the exchange value of their bodies. There is only a difference of degree between Tome's prostitution, her life in the village and her relationships with her lovers. Only after she becomes the madam of a call ring and thus gains access to capital Tome can have a relationship based on mutual respect with Karasawa as I have shown above. However, she works illegally and her financial stability will be soon destroyed ironically by the anti prostitution law, a law ostensibly passed to help women but which in fact created new forms of disciplining their bodies. Fujime Yuki has pointed out the politics surrounding the anti prostitution law and its impact on women in the trade. ${ }^{31}$

Due to the spread of STD (sexually transmitted diseases) among the U.S. military personnel, the General Headquarters of the US Occupation forces (GHQ) ordered a crackdown on prostitution, dismantling the Recreation and Amusement facilities provided by the Japanese government in 1945. The result was that thousands of women were put out in the streets a year later. Despite the pressure, the Japanese government passed a law against prostitution only in 1956 but meanwhile there were random cases of crackdown, imprisonment and forced medical examinations. ${ }^{32}$ As Fujime suggests, although there were many women's groups involved who supported

\footnotetext{
${ }^{30}$ Mihalopoulos, "Becoming Insects," 285.

${ }^{31}$ See Fujime Yuki, "Japanese Feminism and Commercialized Sex," In Social Science Japan Journal, Vol. 9, No. 1 (2006): 33-50.

${ }^{32}$ Ibid., 36.
} 
the anti prostitution law on behalf of women, the result was not in favor of prostitutes since it added new dimensions of violence. The establishment of the 1956 regulations for the prevention of prostitution was presented as the fruits of a movement that triumphed on account of women's solidarity. In reality, however, it was the government itself, at the behest of GHQ that sought to establish laws outlawing prostitution, an effort that began with the 1948 bill." 33 Ironically, Tome owes to these laws both her rise to power and her defeat. She turns Madam Suma to the police and becomes herself the madam of the girls. However, one of the girls turns her in and she spends a year in prison. She comes out utterly desolate, confused and most of all, poor. Karasawa has meanwhile started sleeping with her daughter because she needed money from him. Her whole world crumbled during the time she spent in prison. I will analyze more closely the scene of her coming out of prison in order to show the further disempowerment of women by the anti prostitution law.

The editing alternates between the street shots and the interior of Karasawa's shop. The still image shows the year 1961 and Hidari Sachiko looking ten years older than the shots a year before. Her face without makeup and full of wrinkles, she walks fearfully among cars gripping the small bundle of her meager possessions. She starts crying and leans on Karasawa asking why he didn't come to visit her. He gives her some money and treats her very coldly. Because of her imprisonment she is again fully dependent on Karasawa who does not love her anymore. Because she was in jail her daughter who has run away from home ended sleeping with Karasawa hoping he will give her the money she needed. As long as women gained a place in society mainly through their bodies, the criminalization of prostitution further extended their oppression.

\footnotetext{
${ }^{33}$ Fujime, Japanese Feminism and Commercialized Sex," 39.
} 


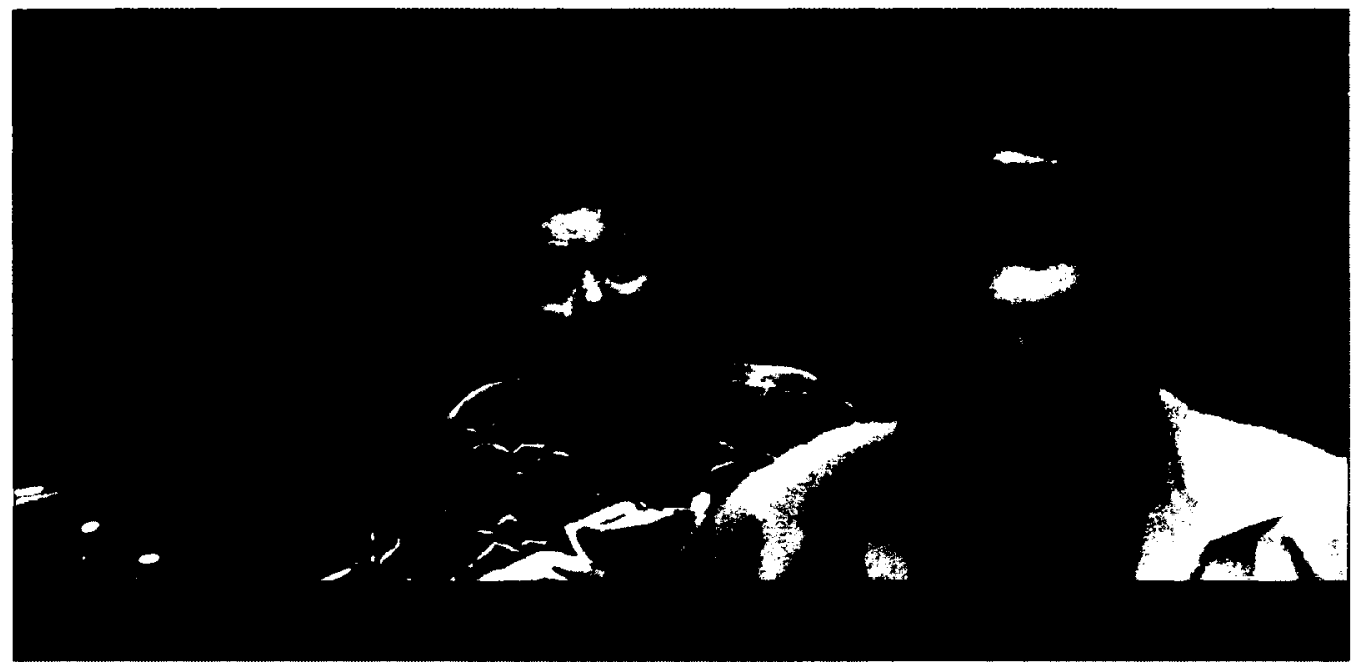

When she comes out of prison for running a brothel, Tome reaches out for her former lover who shuns her.

Sexuality is a means of survival for women based on the denial of their own need for pleasure and intimacy, which constructs their bodies as objects to be used and exchanged within a heteropatriarchal social structure. Prostitution is the literal configuration of women's exchange value as bodies alienated from their subjectivity. Class and gender subordination are reproduced even in a system purporting to protect women, like the democratizing measures taken by GHQ. Many feminist theorists critique the prostitution system because the sexual body is an integral part of a person's identity. Women who work as prostitutes because of economic need experience an alienation of their bodies from their subjectivity through the commodification of their sexuality. ${ }^{34}$ The following part will consider pain and cruelty as bodily affects that governed the rituals of the disciplining of Tome's body.

\section{Pain, the Female Body and the Reproduction of Cruelty}

The film starts with the representation of Tome's mother labor pain. A closeup of her contorted face and the sound of her moans put the female body under the natural law of reproduction and pain. Women experience an aspect of their sexuality

\footnotetext{
${ }^{34}$ Carole Pateman, The Sexual Contract (Berkeley: Stanford University Press, 1988), 207.
} 
through physical pain, which connects them to a cruel law of nature that Imamura highlights again through the representation of Tome's pain when she gives birth to her daughter. Female sexuality connects generations through birth but it is also a lesson in the suffering of life. However, pain is not only inherent in the materiality of the female body in the film but also the result of human relationships. Besides bodily pain inflicted through direct violence against the body or suffered through birth there is also the pain of rejection and betrayal in sexual relationships. Pain is in this case a means of interaction between the subject and others via the body, disciplining the body in specific ways through the transgression of its boundaries.

Pain and grief can be argued to be the deepest forms of engraving, or disciplining the body. As Grosz states, "The analogy between the body and a text remain a close one: the tools of body engraving-social, surgical, epistemic, disciplinary-all mark, indeed constitute, bodies in culturally specific ways..." ${ }^{35}$ While Grosz discusses the relationship between pain and memory in terms of the establishment of social law through punishment, I am interested here in pain as a form of affect that articulates the sexual relationships in the film. Relationships that involve emotions of love, trust and attachment are instances of vulnerability where one is open towards the other, making the pain of rejection or betrayal all the more serious. As Judith Butler has noted, there are two sites through which we become "undone," in other words, through which the boundaries of bodies and subjectivities are breached: "grief and rage on one hand, desire for the Other on the other hand." 36 Pain is a constant marker of Tome's relationships with her family and the men she encounters in her life, a form of "undoing" her subjectivity. Pain is closely connected to women's

\footnotetext{
${ }^{35}$ Elisabeth Grosz, Volatile Bodies. Toward a Corporeal Feminism (Bloomington: Indiana University Press, 1994), 117.

${ }^{36}$ Judith Butler, Undoing Gender (New York: Routledge, 2004), 18.
} 
experience of their sexuality within a heteropatriarchal social structure and it implies a form of breaching the boundaries of the body and "undoing" their subjectivity.

The pain she experiences engraves Tome's body not through the construction of an internal depth but through her cruel behavior towards others. Instead of being overwhelmed by the repeated experiences of pain, Tome struggles to survive and turns her pain into a weapon. Pain is present in the film as an externalized emotion that circulates in-between bodies governing the ways in which they relate to each other. It perpetuates a cycle of violence that tends to turn the victims into victimizers and the other way around, shifting from grief to anger and from there to cruelty. Cruelty means to ignore the others' pain and even inflict it especially in moments of vulnerability. The movie shows many instances of ironic repetition, when the suffering of pain (both mental and physical) reproduces the desire to inflict pain on others. Tome is betrayed by Madame Suma who locks her in to be raped by a client and she takes money from the transaction. When she works as a prostitute she is taken to the hospital where she screams in pain while the doctors hold her down. She has an ectopic pregnancy and needs an operation. After being hospitalized the madam refuses to pay for her hospital bills making Tome even more indebted. In revenge Tome turns her in to the police and becomes a madam herself, being no less cruel in exploiting women.

I will analyze here more closely the scene that epitomizes the circulation of pain as a form of affect governing the relationship between bodies and subjectivities. In a medium close-up we see Tome returning from the business and carnal transaction with Karasawa's business partner. With her face contorted by anger for Karasawa's betrayal of her trust, she looks ominously at the hot pot the maid places in front of her, puts her hand in and says: "it's not hot. I can take a lot more than that." Her feelings 
of anger and grief produce bodily pain and spread like a contagious disease when she wants others to suffer too and she burns her maid too. ${ }^{37}$ The following scene is symbolic for the objectification of women's bodies in the form of ownership one can take over the other. She takes the maid to a doctor for an aesthetic operation asking him to use vinyl since it is cheaper. Later on when the maid does side jobs so that Tome wouldn't take her money share from prostitution, Tome beats her savagely. The camera can barely contain the destructiveness of Tome's rage, since the two women chase each other running too close or even disappearing from the frame. She slaps and pulls the maid's hair screaming: "Who made you? You are fake. I paid for all this and I will tear it apart."

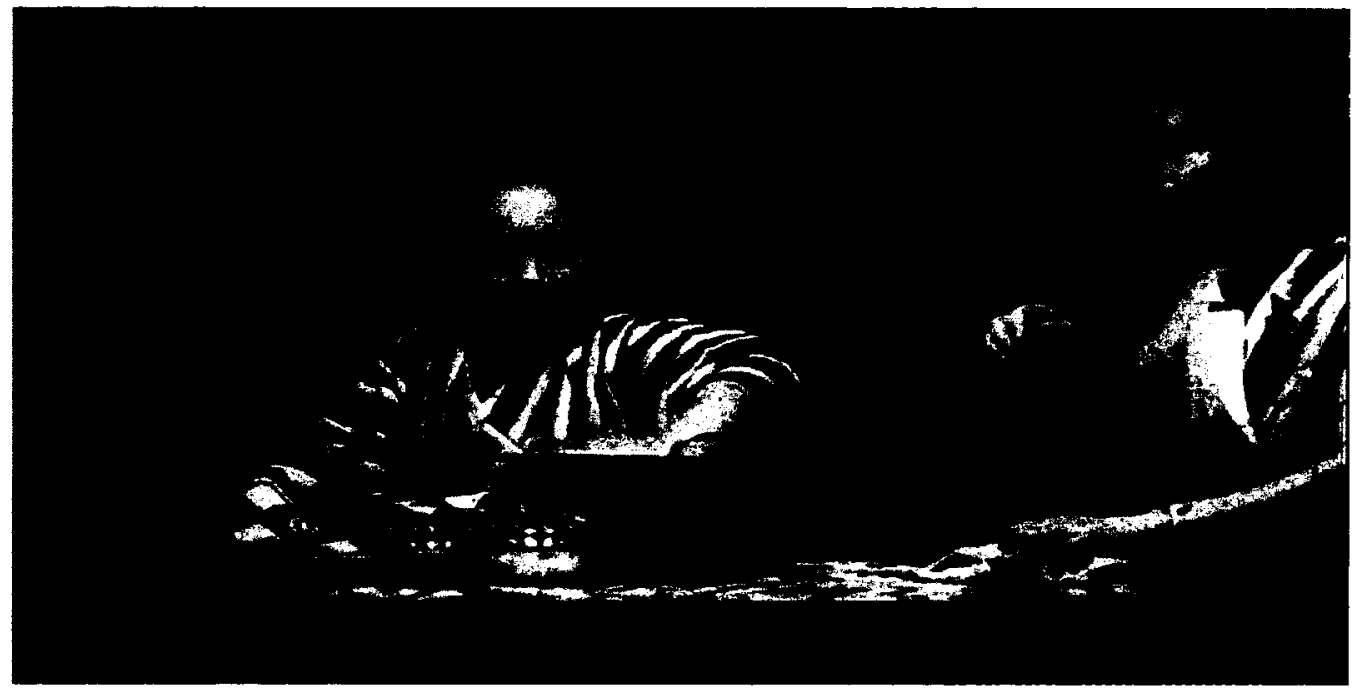

After her lover used her as a sexual bribe Tome returns home and transforms the pain of betrayal into physical pain by putting her hand in boiling soup.

The worst form of cruelty portrayed in the film are of women against women, which explains why Satō thinks there is no indictment of male oppression in Imamura's films as we see in Mizoguchi Kenji or Shindō Kaneto's representations of

\footnotetext{
${ }^{37}$ The relationship between grief and masochism as a social force that engraves the body and it reproduces in the subject's desire for bodily pain.
} 
women. ${ }^{38}$ Pain and grief mark in this film women's sexuality through the experience of birth and their sexual relationships that continuously defy their need to be recognized as subjects. Instead of a continuous, virtuous suffering that characterize Mizoguchi's female characters, Tome appropriates the cruelty she experiences and directs it at other women. I will presently analyze this aspect of women's willing participation in a system that dehumanizes them through their objectification of other women.

\section{Women's Patriarchy?}

How can we define the systems of oppression that disciplined Tome's body? Patriarchal oppression does not only mean the immediate abuse of a woman by a man but the creation of larger social systems that disadvantage women. Oppression in the film is situated at the intersection between gender and class. The subordinate status of poor country girls opens the women in the film to various forms of bodily subordination epitomized by prostitution. In the rural context described in the film, female sexuality seems less regulated by patriarchal figures since Chuji, the patriarch of the family is slow witted and lacking any form of power within the family except for his occasional violent outbursts. The father is not a patriarchal figure but is on the contrary the most stable source of attachment for Tome. Unlike her mother, he is the only one who shows affection, who refuses to send her away and who grieves when she leaves for the city. Their relationship verging on incest is based on a bodily communication, which, together with Tome's relationship to her daughter are portrayed as the only true forms of affectivity. Standish notes that "Chūji's status as half-wit "is not coded negative, but marks him as innocent and links him more closely to nature through the mountain deity and the pre-modern ideal." ${ }^{39}$ The film also shows

\footnotetext{
${ }^{38}$ Satō, Currents in Japanese Cinema, 83.

${ }^{39}$ Standish, Politics, Porn and Protest, 90.
} 
him as a nostalgic figure completely helpless when faced with modernity and Japan/s historical change.

The mise-en-scène of Tome's family presents a Shintō goddesss that presides over all members and it is the women of the family who decide Tome's fate. Her mother and grandmother are ruthless and devoid of affection. Does Imamura want to suggest that they are the bearers of natural norms of survival, of life and death? Is this his biased view of matriarchy or does he want to suggest that things were not necessarily easier for women in matriarchal societies? We can see in the rural context a matriarchal religion coupled with a feudal social system based on the inheritance of the first sons and the subordination of poor farmers. Tome's body is in this context a source of labor and reproduction and the women in her family insist that she accepts her fate as the will of the gods.

Men are described by Imamura as helpless (Chūji) or selfish (Karasawa) but they are not shown to be cruel in the same way women are to other women. The representation of weak men is in tone with Imamura's entire work and it is also a feature of many New Wave films. ${ }^{40}$ This representation is closely associated with the self-reflexive representation of men's sexual desires that are not extended through the cinematic male gaze. The camera does not align with male desire but instead exposes it with irony as a mixture of power, weakness and even ridiculousness. Chuji is the father who mixes parental attachment with sexual desire, Tome's first boyfriend only thinks of sex when she is sick and feverish while the clients of the prostitutes want proof of virginity. Karasawa's sexual desire is visually represented through a series of

\footnotetext{
${ }^{40}$ See Saito Ayako, "Ushinawareta farusu wo motomete" [Reclaiming the Lost Phallus] in Eiga no seijigaku [Film Politics], eds. Hase Masato and Nakamura Hideyuki (Tokyo: Shosha, 2003), 62-106. and Satō, Currents in Japanese Cinema.
} 
freeze frames of his old, hairy body against the youthful body of Tome's daughter. He caresses her while promising her money and the scene ends with her hysterical laughter when his dentures fall while attempting to make love. Intentions of Murder performs the same ironic representation of male sexual desire as a form of preying on women's sexual and maternal bodies, a subject I will explore in the second part of this chapter. Sexual relations are indeed analyzed with the eye of anthropologist as instinctual forces tamed, sustained or denied by social institutions. The camera does not support the male gaze as we do not side with men's desire for female bodies, but we are instead witness to the intricate relationship between the sexuality of the bodies and the norms of heteropatriarchal institutions. Imamura represents gender differences from a self-reflexive standpoint that problematizes male privilege and female subordination under the appearance of men's weakness and women's strength.

Tome's initiation into prostitution is the result of the Madam's cruel betrayal of her trust and innocence. The system of prostitution is one that enacts women's objectification denounced by the film as a heteropatriarchal system in which women participate by abusing other women in order to survive. Both the rural feudal system and the urban prostitution system are oppressive because they reduce women to the sexual potential of their bodies and both systems survive through women's participation. This is what Tome learns as a result of the disciplining rituals I outlined above: to exploit her body as an object, deny her sexual desires and exploit other women. Even her economic empowerment is a result of continuing the cycle of cruelty whose victim she was herself. She has successfully learnt to love the system that abused her. In the following part I will analyze Intentions of Murder focusing on rape as a trope that condenses specific sexual practices and gender norms in postwar Japan. 


\section{At the Frontier of the Skin: Rape and Body Politics in Intentions of Murder}

As I have stated in the introduction to this chapter, Imamura wanted to reveal in his films the sexual, instinctual energies of people that transcend history and culture. Is it thus a paradox that Imamura's quest for the bedrock of human nature led him to the unfolding of yet other cultural norms working through the body? His films centered on female characters reveal the complex process of negotiation between female bodies and heteropatriarchal norms, defying easy assumptions about the body as the bedrock of nature. I will analyze Intentions of Murder arguing that the film investigates rape by representing the dialectic relationship between female subjectivity and two forms of power that inscribe her body: the feudal family and the heteropatriarchal privileging of men's access to female bodies.

Rape as a form of sexual, embodied violence raises troubling questions about historical norms of sexuality. Both Western and Japanese legal and popular discourses sometimes assume, in keeping with the idea of inherent, oversexualized traits of the female body, that some women are guilty of inciting rape and that others enjoy rape because of their innate masochism. ${ }^{41}$ Relying on the feminist critique of the naturalization of the body as an unchanging, innate structure, I argue that Intentions of Murder questions these two aspects of rape by representing the female body as a sexual frontier disciplined by and negotiating various forms of patriarchal power. In doing so, I connect the cinematic representation of rape both to gender politics in Japan and to contemporary theories of embodiment, highlighting the relevance of the film to an understanding of the historical, political positioning of the female body in postwar Japan. Before proceeding to the analysis of the film, I would like to explain

\footnotetext{
${ }^{41}$ See Joanna Bourke, Rape (London: Virago Press, 2007) and Catherine Burns, Sexual Violence and the Law in Japan (London: Routledge Curzon, 2005).
} 
the issue of rape as a discourse of sexual difference sustained through the eroticization of violence and the disciplining of the female body by heteropatriarchal norms.

\section{Rape at the Intersection of Institutional Forms of Violence}

In Contingent Foundations (1992) Judith Butler argues that, "the politics of

violence operate through regulating what will or will not appear as an effect of violence. ${ }^{, 42}$ In the case of rape, the sex of the woman is responsible for her own violation, and thus the power involved in the construction of the female body is obliterated. The sexualization of the female body according to male desire becomes "the formative principle of the [female] body," and thus an aspect of its nature. ${ }^{43}$ The very legal terms enact a violation by sustaining the subordination of the female body, a situation pointed out by Catherine Burns in her study of sexual violence in Japan: "The woman who experiences her body in this way does not locate the dangers presented to her body as originating from outside of her body. Rather, they have as their source the fact and nature of her body itself." configuration of female sexuality in Japan arguing that it is crucial for understanding sexual violence. ${ }^{45}$ She uses the concept of eroticized violence, showing how the pervasiveness of images of sexualized and dominated female bodies in the media structures the treatment of rape in the Japanese legal system. Her concept is useful for my historical exploration of the ethics and aesthetics of Imamura's film.

Made in 1964, Intentions of Murder exemplifies the preoccupation with sexuality and violence of the Japanese New Wave filmmakers. ${ }^{46}$ The 1960 s was a period of financial crisis for all major studios in Japan, which prompted some of them,

\footnotetext{
${ }^{42}$ Judith Butler, "Contingent Foundations: Feminism and the Question of 'Postmodernism," In Judith Butler and Joan W. Scott, eds., Feminists Theorize the Political (New York: Routledge, 1992), 18.

${ }^{43}$ Ibid., 19.

${ }^{44}$ Burns, Sexual Violence, 34.

${ }^{45}$ Ibid., 33.

${ }^{46}$ Satō, Currents in Japanese Cinema.
} 
most famously Nikkatsu, to exploit pornography and to participate in the pervasive commodification of the female body that Burns and Yunomae Tomoko note in their studies on sexual violence in Japan. ${ }^{47}$ Imamura made this film at Nikkatsu studios, but unlike many other films in this period that represent rape as a minor event in the male character's exploits, rape is in this film a central trope for exploring female resilience and strength. ${ }^{48}$ It is worthwhile analyzing Intentions of Murder as a serious exploration of rape in this historical context precisely because this was a time when the visual medium in Japan began exploiting eroticized violence. On the surface, Intentions of Murder eroticizes violence, but I argue that it also questions the norms of sexual difference and the construction of female sexuality through a regime of structural violence. The essential ambiguity of the film - in its portrayal of eroticism and violence, pleasure and pain, sexual desire and desire for revenge-makes it impossible to contain its multiple proliferating meanings. At the same time, that ambiguity opens up debates about what is defined as the nature of the female body in the 1960s Japan. In what follows I question the mechanisms of power involved in the construction of sexual and class difference.

Butler in the American context and Burns in the Japanese context criticize the structural violence of the heteropatriarchal systems that contribute to the existence of bodily sexual violence. This violence is enacted through the sexualization of the female body and its naturalization as an object of male desire. There are two consequences for this positioning of the female body in the case of rape. First, the body is already sexualized and thus can be blamed for rape. Second, female sexuality

\footnotetext{
${ }^{47}$ Yunomae Tomoko, "Seibōryoku wo meguru onnna no undō" [Women's movement concerning sexual violence], Kanō Yoshiko and Kanō Mikio, eds., Onnatachi no shisen, ikiruba no feminizumu [Women's viewpoint, embodied feminism] (Tokyo: Shakai hyōronsha, 1990).

${ }^{48}$ Ibid., 92.
} 
is regarded as inherently masochistic and repressed, sometimes even "requiring" a little force. The eroticization of violence as a discourse of sexual difference is a central issue in Imamura's film. Intentions of Murder reworks scenarios that naturalize the female body as sexual and masochistic through two cinematic devices: flashbacks that give us access to the main character's past experiences, and representations of inner states via bodily gestures, dreams, and metaphors.

\section{Patriarchal Power and Female Resilience}

Intentions of Murder explores in complex ways the interactions between violence and eroticism, between the oppressive patriarchal family and the supremacy of male sexual desire at the level of the female body. Situated in the harsh climate and the rigid feudal family system of northern Japan during the 1950s, the film portrays the story of Sadako (Harukawa Masumi), a woman who survives various forms of structural violence. Her story is told in flashbacks, which show that she was brought into the present household to work as a maid. Raised in Tokyo, she is the illegitimate granddaughter of the previous head of the household (ie). She now lives with one of the sons of the present household, Koichi (Nishimura Kō), under the precarious status of concubine. They have a son, coveted by the family as the only male heir, but Sadako remains a source of sexual shame not worthy of entering the family. She is socially and economically dependent on Koichi but is also trying to earn her own money by learning how to use a knitting machine. One day a thief, Hiraoko (Tsuguyuchi Shigeru), breaks into their house and, after a violent and disturbing fight, rapes her. He keeps returning and claiming that he loves her, but she resists his desire to run away together. She hates the rapist and plans to kill him, but faced with his misery and hearing his life story, she hesitates because his story humanizes him (unlike the silence that dehumanizes her in her sexual contact with both men). Finally, 
the rapist dies of a heart attack. She becomes part of the family together with her son, after vehemently denying the secret of her rape, regarded as a sexual affair by others.

Imamura was fascinated by the vitality and survival instinct of women, which makes them interesting subjects for his films. "That's my ideal view of a woman; she must be strong, willful, full of vitality and attach herself to weak men-like me!" Imamura says half-jokingly. ${ }^{49}$ Similar to Insect Woman, there is a striking contrast in Intentions of Murder between the weakness of individual men in the film and the power of the patriarchal institutions that protect them. Koichi, Sadako's not yet legal husband, calls for his inhaler when he returns home and requires Sadako to nurse him during his repeated bouts of illness. Hiraoko, her attacker, looks to Sadako for maternal and sexual gratification because his doctor told him he would die soon of heart disease. Both men need and demand Sadako's maternal and sexual favors without acknowledging her as a human being, while Sadako must comply with their desire in order to be acknowledged as a viable social being. The feudal family dehumanizes Sadako because she was born out of wedlock. She is a source of shame for the household, and this situation favors Koichi's complete power over her. He has a mistress at work but uses Sadako at home as a maid, nurse, and occasional lover. Social norms of decency that associate rape with female shame favor the attacker Hiraoko, who, ironically, threatens that he will reveal their sexual relations and thus destroy Sadako's already precarious social status. Sadako's low class position makes her vulnerable to power norms that exclude and dehumanize her.

Sadako is a strong, willful woman who prevails over men through the appropriation of male desire and her growing awareness of her subordination, but she is neither a victim nor a heroine. Women's vital instincts measure up to the

\footnotetext{
${ }^{19}$ Tessier, "Shōhei Imamura, Modern Japan's Entomologist," 59.
} 
interdictions and oppressions they have to face. This instinct is not a natural, opposing power inherent in female subjectivity, but it is at times the force that makes women comply with male desire in order to socially survive. Giles Laprevotte situates Imamura's cinema as "an in between, a troubling and disturbing balance" between instinct and the cultural norms of socialization. ${ }^{50}$ This in-between status enables my reading of the body as an interface between subjectivity and culture, whereby the body's nature is permanently elusive and ambiguous, being shaped by cultural norms.

Elizabeth Grosz argues that, "the female body has been naturalized as the site of eroticized sexuality and it has been defined as nature existing prior to cultural institutions." $"$ The only socially recognized and validated representations of female sexuality are those conforming to a heterosexual structuring of male desire. ${ }^{52} \mathrm{Her}$ argument, like Butler's, is that female sexuality has been constructed by maledominated cultural norms and, even more than that, its construction has been obliterated and inscribed on the female body as the woman's essential, natural trait. The next section considers how the main character becomes embodied through various acts of interdiction and oppression that structure her response to rape. Rape functions in the film as an essential bodily interaction between patriarchal power and female subjectivity, more precisely as a form of sexual violence that triggers awareness of other forms of institutional power through flashbacks. It is a form of bodily vulnerability that echoes the vulnerability of the female position in a heteropatriarchal social system.

\footnotetext{
${ }^{50}$ Gilles Laprevotte, "Shōhei Imamura: Human All Too Human," In James Quandt, ed., Shōhei Imamura (Toronto: Toronto International Film Festival Group, 1997), 104.

${ }^{51}$ Butler, "Contingent Foundations," 16.

${ }^{52}$ Butler, Bodies That Matter, 202.
} 
Flashbacks: The Female Self in the Sinfully Sexual Female Body

Through various flashbacks inserted at key moments, we learn about Sadako's history and the subordination of her body at the intersection of gender and class. A flashback in the first scene explains Sadako's spatial and temporal positioning. She was brought in from Tokyo as a maid to Koichi's family, where she belongs as the illegitimate granddaughter of the previous master. Her mother dead now, Sadako is brought by a relative to work in this household in Sendai. She is in an inferior position due to both her sex and to her class, and she must learn to respond to the others' desires. The power of the feudal family sustains the naturalization of her body as sinfully sexual by inscribing the sexual desire she inspires in men as a normative, innate trait of her body. Moreover, as an illegitimate child she is an ancestral reminder of the sexual promiscuity of the previous head of the family, and hence is viewed as an embodiment of sexual sin. Her body bears the mark of another generation's sexual misconduct.

The act of sexual violence triggers flashbacks of other mistreatments of her body. In this sense, rape is represented in the film as an interaction point, a moment in which the border of her body is transgressed. The violence against her body coming from outside plunges us beyond the frontier of her skin to her memories, her interiority, which is not an immutable, bounded self but a self connected to culture through the mediation of the body. Grosz's Möbius strip model becomes relevant here in order to understand how rape awakens bodily memories. Sadako's body was originally formed through acts of sexual and social repression. The shot of the attacker's caressing of her legs in the film is followed by a flashback that shows how Sadako sensually enjoyed the feeling of a silkworm crawling up her leg. The mistress of the household intervenes and brutally beats her, calling her "child of a whore." Her sensuality is a sign of the sexual shame surrounding her birth. The mistress of the 
household acts as an authority figure carrying the power of the patriarchal family to exclude and dehumanize Sadako because of her position both as a maid and as a sexually threatening reminder of desires not contained within the feudal family.

The other flashback occurs through a series of edited shots following Sadako's washing of her body after the rape. It is unclear in this case whether the flashbacks are subjective aspects of her memory or explanatory inserted scenes. A medium close-up shows her body wincing under the jets of cold water, a sign of her desire to get rid of pollution. The next shot takes us back in time and space to a room where she nurses Koichi, her present partner, who is chronically ill. When she tries to take his temperature, he drags her into bed despite her refusal. "No, don't! You mustn't," she pleads with him, fighting back, but he ignores her and behaves as if no means yes. When he is on top of Sadako, his mother comes in and hates Sadako even more for sexually luring her son. Sadako is to blame for being raped by her master. Two institutional forms of oppression intersect here, reinforcing each other: the rules of the feudal family, and the supremacy of male desire. Both of them situate Sadako's body as an object to be consumed, rejected, and reviled.

Catherine Burns shows how rape is sustained by institutions that disempower and naturalize the female body as sinfully sexual: "The body marked as feminine is inscribed as rapable, that is, vulnerable and passive, and this facilitates the elaboration of masculine power, not just in the fact that the body can be taken, but also that the body can be blamed for the taking. Women are held accountable for their own victimization unless they can prove themselves to be innocent or pure." ${ }^{53}$ The naturalization of the female body as the mark of guilty sexuality reinforces male power over women's bodies. In this case the feudal family normalizes male violent

${ }^{53}$ Burns, Sexual Violence, 33. 
eroticism by placing sexual shame and norms of decency upon the female body. The flashbacks Sadako has during and after her rape, show that her body has already been disciplined by sexual and class norms. As Butler suggests, "[sex] is not a simple fact or static condition of the body, but a process whereby regulatory norms materialize 'sex' and achieve this materialization through a forcible reiteration of those norms." 54

Sadako's sensuality has been suppressed, and her body has become the site of sexuality as projected by male desire. All lovemaking scenes between Sadako and Koichi show how rape is on a continuum with the objectification of her body as the sex constructed by male desire. She hopes to become Koichi's wife, especially after giving him a son who is important for the continuity of the family line, yet she continues to live with him under the uncertain status of maid and lover. Koichi's family tries to register the son in the koseki (family register) and thus take him away from her without including her in the family. The film therefore does not present the Sadako's rape as the only form of sexual violence in the story; rather, it explores various forms of violence enacted on her body, including class difference, illegitimate birth, the patriarchal structure of the feudal family, and the privileging of male desire.

Catherine MacKinnon has brought attention to an entire culture of female subordination that supports sexual violence against women. Although I do not entirely agree with her arguments, I believe that paying attention to the institutionalization and normalization of heterosexuality is important for exploring the issue of sexual violence. MacKinnon writes: "Separating rape from the realm of the sexual and placing it in the realm of the violent, allows one to be against it without raising any questions about the extent to which the institution of heterosexuality has defined force

\footnotetext{
${ }^{54}$ Butler, Bodies that Matter, 2.
} 
as a normal part of 'the preliminaries." burglar functions to open the frontier of her body to her memories of other forms of bodily discipline. The violent rape acts as a traumatic moment that reveals two other traumatic moments in her life history: the suppression of her sensuality, and the violence of the heterosexual institution that places male sexual desire as an inherent trait of her body. Through the flashbacks in Intentions of Murder, the burglar's violent rape is situated on a continuum with the violence of the very institutions that would supposedly protect Sadako's body. The household where she is treated as a maid abhors any manifestation of her sensuality, whereas Koichi's sexual desires are inscribed as a trait of her body. The next section shows how rape is staged in the film as a quintessential reduction of the woman's body to a sexual object stripped of the presence and dignity of the self. Does the portrayal of an act of sexual violence perpetrate that violence through cinematic pleasure, or does it undermine it through its alternate focus on the subjectivity of the female character?

\section{The Scene of Rape: The Desirable Unconscious Female Body}

The rape sequence is shot from an omniscient camera position that refuses to identify with either the rapist or the victim. The sequence is deeply disturbing because of its mixture of extreme violence and moments of tenderness. This mixture places the sexual encounter under two apparently contradictory signs: the harming of the body as a disciplining through violence and as a silencing of female subjectivity, and the tender touch as a search for the sensual responses of the body, for the presence of the woman's desire.

A thief, Hiraoko, enters the house to steal money. Looming over Sadako on the right side of the frame, he threatens to kill her unless she gives him money. When

\footnotetext{
${ }^{55}$ Catharine MacKinnon, Sexual Harassment of Working Women-A Case of Sexual Discrimination (New Haven: Yale University Press, 1979), 219.
} 
she hears noise from outside she tries to run and call for help, but he attacks her and a violent struggle ensues. He beats her unconscious and comes into the next room (where the camera is placed) to take the money. Through a point-of-view shot that includes the image of the rapist himself, we momentarily align with his gaze at her unconscious body, thus participating in the visual eroticization of violence. A dangling light bulb shows a rhythmically lit image of Sadako's half-naked, unconscious body through the open screen. Her body inflames his desires once she is unconscious, bruised, or in pain. The next shot metaphorically shows the blinding lights of a train rushing in, with the subsequent deafening noise, a visual metaphor I analyze more closely below.

Through our visual alignment with the rapist and his desire through a point-of view shot, the director is naturalizing Sadako's body as luring and sexual, though the subsequent position of the camera will dissociate spectators from the desirableness of an unconscious body. The rapist ties a gag around Sadako's mouth and binds her hands, rendering her body silent and powerless, a recurring motif of Japanese pinku film. ${ }^{56}$ As I stated in my analysis of Insect Woman, the difference between Imamura's approach and pinku film is that he shows how the female body becomes objectified instead of relying on this pattern to create visual erotic pleasure. Through its focus on female subjectivity and her reaction to rape, Intentions of Murder complicates the visual aesthetics of the male gaze. It maintains instead a scrutinizing distance to the power of male desire and the harm it inflicts on the female body. The rapist's desire is enacted on Sadako's body without any resistance, and her literal bondage metaphorically marks the bondage of her social subordination. Violence is thus not

\footnotetext{
${ }^{56}$ See Sharp, Behind the Pink Curtain.
} 
only an act of harming the body but also one of silencing the woman and reducing her to an inert body brought to life by male desire.

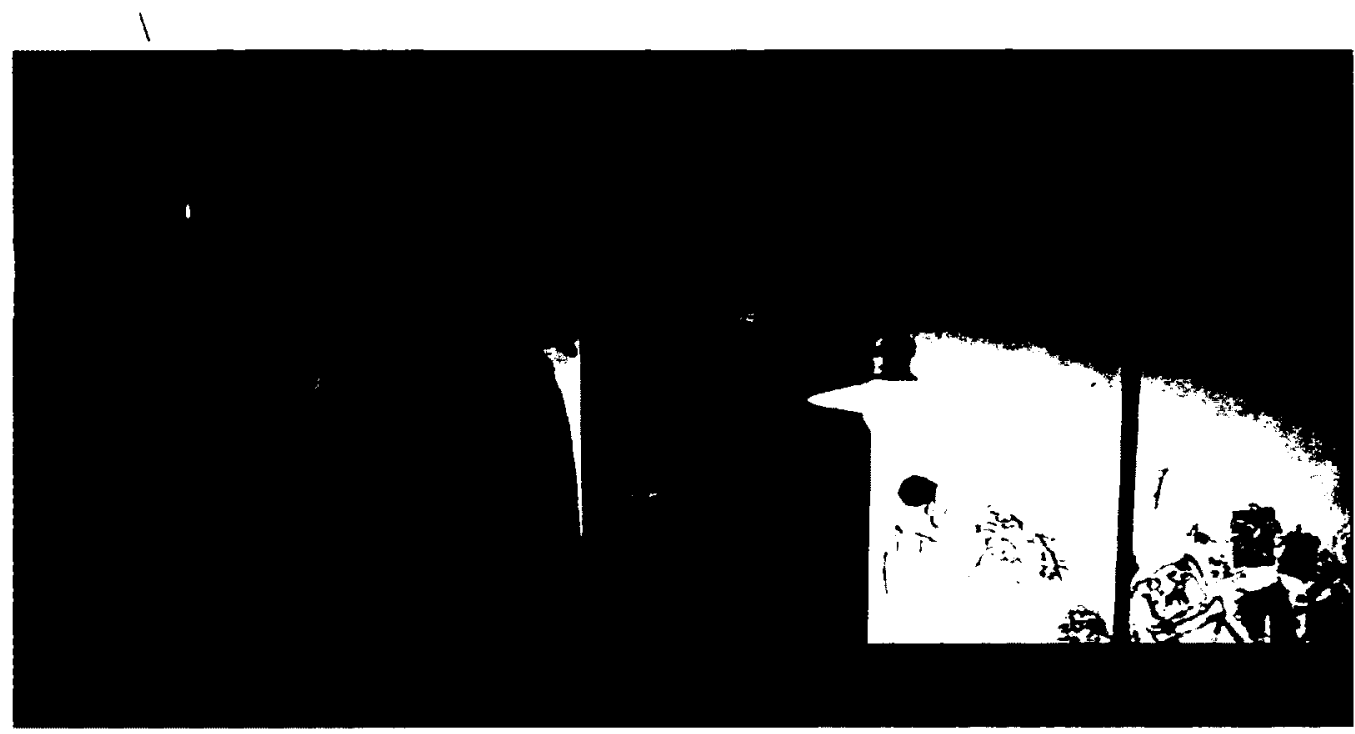

The camera aligns here momentarily with the male desire for the woman's body deprived of its subjective presence but it still maintains an objective distance that analyzes the formation of his desire.

After the rape, the camera changes position and captures a medium close-up shot of their faces. The rapist unties Sadako, and seeing the bluish marks on her face and her swollen lip, he tenderly caresses her face. He slowly caresses her unconscious body, and we see a close-up of his hand on her legs. The tender touch implies a reaching out for the other, an invitation for the woman to participate in sensual pleasure, but it comes too late, when the body is overwhelmed by the harm of violence. The tenderness of the caresses following the rape offers a sensation of pleasure after intense pain-an analogy to the patriarchal system in which Sadako can enjoy sexual pleasure only after submitting to the violence of patriarchal institutions.

When the rapist stands up to leave, he throws her some money, aligning her with a prostitute and rationalizing his behavior. Burns makes an interesting link between the raped woman and the prostitute, suggesting that, "in legal discourse the 
rape victim's body becomes sexualized in a way resembling a soft porn script."57 Leaving Sadako money (which he has actually stolen from her), the rapist overcomes his guilt by placing her within an economy of sexual exchange, but also by abjecting her body and making it responsible for the violence enacted on it. He leaves after saying, "If you keep silent, nobody will know about this." The double irony is that he stole the money he throws to her, and that he can rely on her silence and shame about his own shameful act. Sadako cannot rely on help or justice because her body has been polluted by rape.

The spatialization of rape inside Sadako's home is an ironic reminder that home is not a safe space for her, since her home is already built on violence. She does not have a home in the terms suggested by Iris Marion Young, namely, as a space of safety. Endowing home with an important critical value, Young suggests four normative ideals: safety, individuation, privacy, and preservation. ${ }^{58}$ As we see in the film, these basic traits of home are only vicariously available to Sadako. She is "allowed" to have a home because of her son, Masaru, who is regarded as the male heir of the feudal family. Young argues that, "a person without a home is quite literally deprived of individual existence. However minimal, home is an extension of the person's body, the space he or she takes up and in which he or she performs the basic activities of life." ${ }^{59}$ We can see in Young's argument that the space of home is connected to one's body. This space acts as a second layer of skin that implies protection but in Sadako's case implies entrapment in an alien space. Deprived of a home, Sadako's presence is accepted only as long as she can serve others: her (future)

\footnotetext{
${ }^{57}$ Burns, Sexual Violence, 19.

${ }^{58}$ Iris Marion Young, "House and Home: Feminist variations on a Theme," In Constance L. Mui and Julien S. Murphy, eds. Gender Struggles: Practical Approaches to Contemporary Feminism (Lanham, Md.: Rowman and Littlefield. 2002), 343.

${ }^{59}$ Ibid., 342.
} 
mother-in-law, her partner, her child. ${ }^{60}$ The house in Intentions of Murder is hemmed in by the railway tracks, a constricted and constrictive space of domesticity that echoes Sadako's vulnerability to the manifestations of male desire, which are represented visually in the rape sequence through the close-up shot of a rushing train.

The scene of rape literally portrays the female body as a sexual object disciplined through the violence of male desire. The fierceness of Sadako's fight back and her rape as an unconscious body denaturalize the "no means yes" paradigm in which the female is a willing and guilty victim of rape. The sexual encounter at the frontier of her skin takes place through the power of the male desire over her objectified, unconscious body, deprived of subjectivity and of home as an enveloping space of safety and individuation. The following section analyzes the second problematic aspect of rape, based on the naturalization of female sexuality as inherently masochistic and repressed.

\section{Not a Love Story; Denaturalizing Female Masochism}

Scenarios of rape as a love story and as the awakening of the woman to her sensuality abound in popular culture both in Japan and in the West. Through my close reading of Intentions of Murder's ambiguous representation of rape and female masochism, I counteract other critics' reading of Sadako's sexual awakening as a result of rape. In what follows, I argue that masochism is naturalized as an inherent trait of the female body under patriarchal regimes of power. The myth of female sensual awakening as a result of sexual violence pervades many readings of the film, and at some levels this interpretation is allowed by the narrative. However, in the relationship that develops between Sadako and her attacker, he is the only one who is

\footnotetext{
${ }^{60}$ When Koichi suspects that Sadako is having an affair, he beats her savagely, saying that he has allowed her to stay in the family home out of pity.
} 
convinced of a love affair. I argue that the film reworks this myth through a relentless exploration of female embodiment within power regimes.

In his memoir, Imamura points out that Intentions of Murder is about a "woman who discovers within herself the power to stand up to her abusing husband and her mother-in-law" as a result of rape. ${ }^{61}$ The crux of the problem lies in this discovery-namely, the awakening of that power deep within herself. Is this sensual awakening the result of the rape, or is it a transformation of subjectivity through awareness of structural violence? The ambiguity of the film makes possible both readings, and I would like to offer my own reading in contrast to that of the scholars who interpret her transformation as sexual awakening. Ironically, the film presents this ambiguity in its ending. When Koichi confronts Sadako with photographs of her walking in the snow with Hiraoko, she repeatedly and stubbornly claims the pictures do not show her cheating on him. Her refusal to admit the reality captured by the camera questions the ability of the film to show reality. The photos show a love story, when in fact her story is one of rape and desire for revenge. Things are not always what we see with our eyes or capture with a camera, despite the claim of objective representation of reality. As we see here, reality is a matter of contesting perspectives. Sadako's words at this point ironically question both the relevance of the film and the relevance of the multiple interpretations of her rape: "So what? So I am shown here. Of what significance is it?"

\footnotetext{
${ }^{61}$ Imamura, Eiga wa tabi no kyōki de aru, 92.
} 


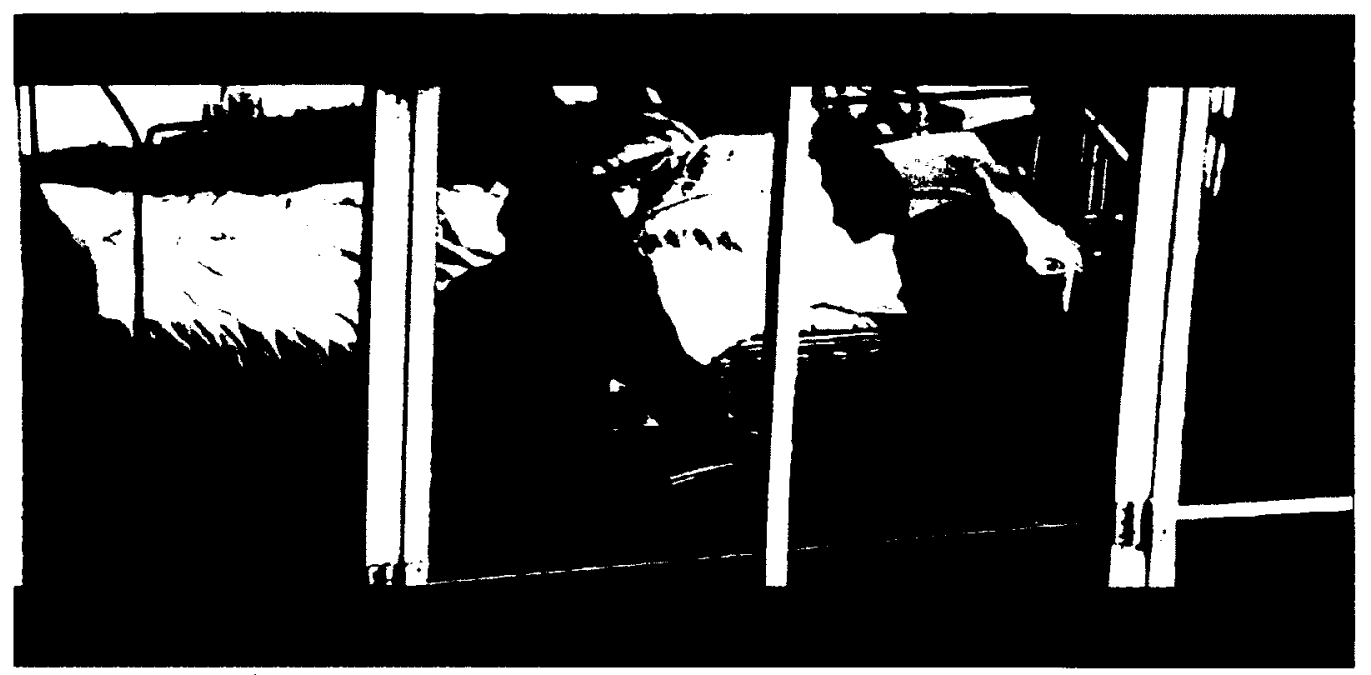

Even when confronted with photographs of her together with Hiraoko (taken by Ryuichi's lover), Sadako denies the visual evidence of a love affair (because things are not as they appear).

The significance of Imamura's film is that it plunges us deep into the ambiguities of evidence and interpretations by pitting the woman's subjective world against her social interactions. The director himself foregrounds this ambiguity through the cinematic description of interactions, gestures, and subjective states. As Imamura himself put it, "I want to enter a character's heart. I want to capture the smallest action, the finest nuance, the most intimate psychological expression because filmmakers must concern themselves with more than facades." ${ }^{62}$ The outcome of rape and its subsequent apparent erotic relationship make possible a variety of interpretations. The most frequent interpretation offered by critics is that of a love story, which is problematic because it is based on the assumption of innate female masochism. I argue that masochism is the only available sexual manifestation for Sadako within regimes of power that reduce her body to an object.

Two film critics writing on Intentions of Murder have suggested that the female character refuses to escape an oppressive relationship by eloping with her rapist. Dave Kehr jokingly writes that the film is "the story of a woman who is willing

\footnotetext{
${ }^{62}$ Imamura, "My Approach to Filmmaking," In James Quandt, ed. Shōhei Imamura (Toronto: Toronto International Film Festival Group, 1997), 126.
} 
to kill in order to preserve her unhappiness. ${ }^{, 63}$ David Desser, too, regards Sadako's rape as a means to counteract the oppression of the patriarchal family through the awakening of her instincts: "It is clearly her awakening to her essential sexuality that enables Sadako, the heroine, to win a victory over patriarchy." ${ }^{164}$ What is the essential sexuality that both Desser and Kehr point at? While I agree with these two critics that the relationship developing between Sadako and her aggressor transforms her, I believe that it is problematic to see their relationship as an adulterous love story. This reading relies on the naturalization of female sexuality as dormant and of male violence as the antidote - a scenario of eroticized violence that pervades many other Japanese films, especially the pornographic genre. Both Koichi and Hiraoko approach Sadako through initial physical or emotional violence and subsequent erotic tenderness, revealing female masochism not as an inherent trait of femininity but as the result of sexual interactions based on power and submission.

Max Tessier argues that Sadako "lived an adventure she would have thought impossible and discovered a new sense of freedom in her sexual relations with a man who had raped her. This view of 'women's liberation' only shocks orthodox feminists who believe that men do nothing but enslave women. ${ }^{155} \mathrm{I}$ am indeed shocked, not by this version of liberation but by Tessier's reductionist and cynical reading both of the film and of "orthodox feminists." Sadako discovers a new sense of freedom because she becomes aware of the systemic violence of a patriarchal system through the overwhelming violence of rape. Kehr, Desser, and Tessier overlook the fact that there is a bitter and deadly struggle between the woman and her rapist, who apparently falls in love with her but who can only approach her through violence. Her sensuality becomes disconnected from herself because she genuinely hates and despises her

\footnotetext{
${ }^{63}$ Kehr, "The Last Rising Sun," 34.

${ }^{64}$ Desser, Eros + Massacre, 126.

${ }^{65}$ Tessier, "Shōhei Imamura, Modern Japan's Entomologist," 51.
} 
rapist but can still be sensually awakened by his caresses. I intend to look more closely at the problematic nature of this sensuality, analyzing the film's ambiguous portrayal of the relationship between eroticism and violence that enables a reading of female sexuality as masochistic.

The harm inflicted on the body triggers violence as an imposition of pain from outside, whereas the erotic touch is summoning sensual pleasure from within. The pain of the body is not only a means of discipline but also brings to the surface forgotten memories. In her interesting account of Nietzsche's theory of knowledge, Elizabeth Grosz reminds us of his insight that "pain is the key term in instituting memory." ${ }^{66}$ Although Grosz refers to the social and legal contracts that bind individuals through cruelty and punishing systems, the close relationship between memory and pain works in Imamura's film to show the molding of the female self through the painful patriarchal inscription of Sadako's body. However, the inscription can never be complete, leaving some room for negotiation. If for Foucault the body is disciplined by power regimes, for Nietzsche the body is an active agent of subjective energies that might disrupt the complete grip of power. ${ }^{67}$ Sadako's subjective memories of her life, triggered by the abuse and touch that result in a mixture of pain and sensuality, disentangle, for us as spectators, her bodily existence within patriarchy from her own growing awareness of systemic violence. Her survival instinct is an energy that resists the power exercised on her body.

On the one hand, Intentions of Murder questions and challenges the pattern of pinku film in which the woman falls in love with her rapist, since Sadako's underlying desire is to kill the man. On the other hand, the film places violence and eroticism, love and hate on the same continuum by turning rape into an unusual love story. The

\footnotetext{
${ }^{66}$ Grosz, Volatile Bodies, 131.

${ }^{67}$ Ibid., 146.
} 
burglar/rapist Hiraoko believes he is now deeply in love; Sadako's partner Koichi thinks she is having an affair; and we see how the repeated forcible intrusions on Sadako, followed by the tenderness of caresses, mark her body with masochism. The second rape occurs when Hiraoko returns to the house and claims that she must be in love with him in the same way he is with her. She runs to call for help, but he catches her and responds to her insults by strangling her. In this scene there is a shot of their struggle in which she sees her face reflected in the household iron Hiraoko is using to threaten her. The iron represents both a weapon and a mirror that will serve the same visual function in her sexual interaction with Koichi. With one hand Hiraoko strangles her, and with the other he holds the iron that reflects back her own choking, distorted face. Imamura and his cinematographer, Himeda Shinsaku, employ here contorted close-ups of Sadako's face, placing lovemaking on a continuum with violence through the visual metaphor of the iron as weapon and distorting mirror.

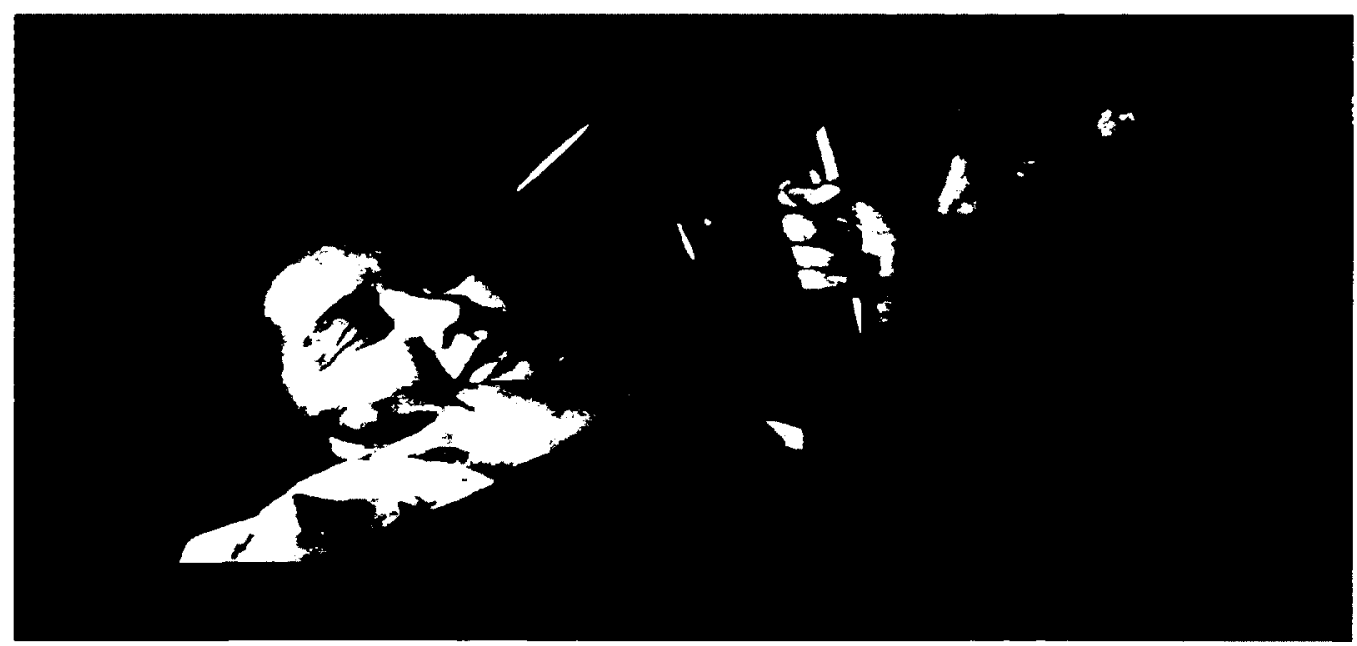

The iron as a mirror and weapon is used both by Hiraoko and Ryuichi in a continuum of violence that contorts Sadako's body and mirrors that contortion to her. We can read this a visual metaphor for the disciplining of female subjectivity through the violence against the body.

The third time Hiraoko rapes Sadako he follows her on the train, where they struggle to push each other out. Believing that he will leave her alone, she agrees to sleep with him. Her body is again inscribed as a form of property that she can use 
within the patriarchal power matrix. It is only during their fourth encounter, when Sadako takes him all her savings in order to persuade him to stop harassing her, that disturbing violence makes space for a tender, classic erotic scene. In this sequence her rapist is humanized, he tries to tell her his life story, how his father died in the war and his mother prostituted herself to raise him, how the day he raped her he had learned that he was soon to die of heart failure. Sadako refuses to listen further and be moved to pity, but she nevertheless comes back, and for the first time we see a classic erotic scene. The film poses the possibility of female sensuality only as a denial of the integrity and unity between the female subjectivity and her body. The body is a betraying site for Sadako because it bears the inscription of the violence of patriarchal institutions, which allows for the existence of female sensuality through the suppression of female social and sexual agency.

Sadako learns to turn her subordination to her advantage (however illusory that may be). Her relationship with the rapist Hiraoko has transformed her subjective relationship with her body. Her sexuality is thus no longer the exclusive property of Koichi, who, dismayed by the possibility of another man desiring the mother of his son and heir, learns to respect Sadako more. His mistress now dead in a car accident and Hiraoko dead of a heart attack, the couple seems to return to "normal," with Sadako now part of the family as Koichi's legal wife. This ending is far from suggesting any feminist liberation-although Sadako's transformation does allow her the very small victory of becoming a legal wife-and it also offers spectators a glimpse of body politics in postwar Japan. Even though Imamura's representations of women do not defy or even critique oppressive institutions, his insistence on ambiguity and the dialectic relationship between embodiment and social institutions 
reveal the norms that sustain sexual violence and critiques a stable form of identity and interiority.

Intentions of Murder poses masochism as the result of female embodiment within patriarchal regimes of power, rather than as an innate trait of the female body. Sadako's body is inscribed through male desire, a desire that acts as a coercive and violent form of power. Her partner drags her into bed right after telling her that she is an idiot and scolding her for being clumsy. Her rapist/lover beats her and threatens to kill her before being tender. What is the possibility of her truly "awakening to desire," as Desser puts it $?^{68}$ Returning to my argument that the body is not a static, unchanging channel of natural sexuality, I argue that the body has the innate capacity for sensual pleasure but that the context that makes pleasure possible is problematic. Not only is eroticism deeply entangled with love but, as Grosz has suggested, it is an act of power. ${ }^{69}$ The female body is the site of disciplinary power, yet this power is not situated only outside; rather, it becomes a trait of femininity and is naturalized as an inherent aspect of the female body. Sadako's body has been disciplined through its violent mistreatment by the feudal family and the two men she is sexually involved with, through a series of acts that open the frontier of her body through pain and pleasure. Masochism becomes inscribed on her body through the interaction at the bodily level between the violence of the patriarchal regime and the capacity for pleasure as response to the tenderness of erotic touch. Tenderness within a context of violence is the only form of eroticism that Sadako knows.

In the next section I contextualize the issue of rape, examining the historical construction of the body's relationship to subjectivity.

\footnotetext{
${ }^{68}$ Desser, Eros + Massacre, 126.

${ }^{69}$ Grosz, Volatile Bodies, 189.
} 


\section{The Harm of Rape: Destruction of Self, Body, Social Status?}

What kinds of changes are brought about by rape, both to Sadako's body and

to her sense of self? How does the inscription of her body as inherently sexual work for her as well as for the people who interact with her? In her historical account of rape, Joanna Bourke suggests that for many nineteenth-century working-class women, the harm of abuse was located less in their psychological selves than in their social and economic standing. ${ }^{70}$ In the twentieth century, however, there was an intense focus on the body as a locus of identity and a marker of truth. The harm of rape came to be seen as the destruction of a woman's sense of self and less for its effects on her social standing (at least in the West).

As we have seen in her flashbacks, Sadako's life is possible only as long as she can exist as the property of a man or of a patriarchal household. Williams Sanders points out in his study of the relationship between rape and women's identity, that losing social face for a woman meant losing value as a person: "Losing face tears to the very heart of a woman's being, her self." events of the film are portrayed, rape was seen more as social harm than harm against a woman's sense of self. The female self was dependent on the female social placement within heteropatriarchal norms that regarded the female body as a form of property.

The shot after the rape is a close-up of Sadako's bruised face. In a voice-over inner monologue Sadako denies reality, telling herself that it was only a dream. This is followed by a point-of-view montage of the objects scattered around the room, bearing witness to the reality of the rape. In a high-angle shot of the room, the camera spins overhead in a slow vertigo, simulating Sadako's disorientation and shock. Her

\footnotetext{
${ }^{70}$ Bourke, Rape, 425.

${ }^{71}$ William Sanders, Rape and Woman's Identity (London: Sage Publications, 1980), 128.
} 
next thought is that she must die. She tries to purify her body with water and burns her ripped clothes_-gestures made to rid her body of the pollution. However, her body is not a static surface that can be cleansed; the pollution has entered her self through her body, and from the intersecting point between outside and inside, the rape enters her inner self. Sadako is about to throw herself in front of the train, but she thinks of her boy, Masaru, and changes her mind. Instead, she turns back home and starts eating, while her voice-over monologue continues, saying, "I have to die."

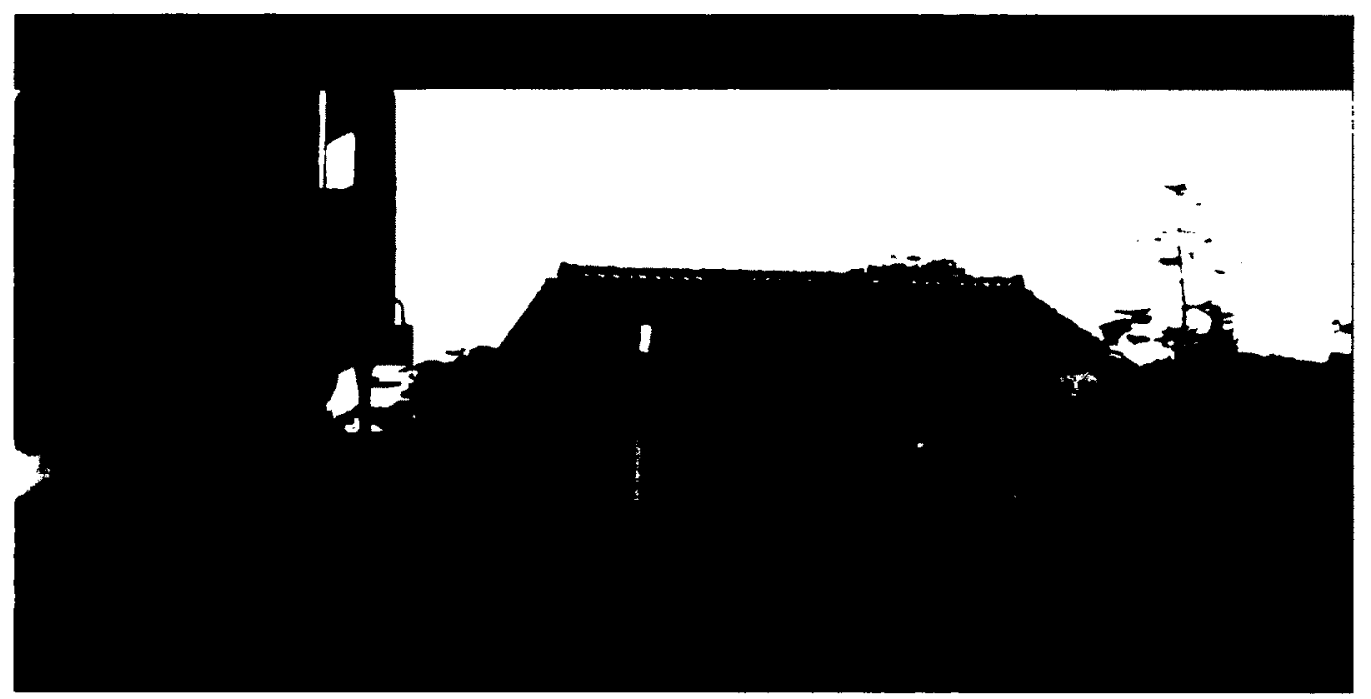

After the rape she runs to throw herself in front of the train in order to wash the shame of rape with her death but she changes her mind.

In an interview on the Criterion DVD, Imamura says that he introduced this scene to disorient the audience, who would not expect Sadako's gesture of eating at such a time. He suggested that he used it to ease the seriousness of the subject with a slightly comical element. The outcome of this aesthetic choice is to move spectators away from the melodramatic identification with the suffering of the character and to observe her instead from a distance. In the next few scenes she broods over death, and asks her son if he wants to die with her. Another scene shows her trying to hang herself, but the rope breaks under her weight and she falls to the ground. The humorous register in which her scenes of attempted suicide are shown raises some 
important questions about Imamura's belief in female strength and resilience. The slightly farcical depiction of the serious issue of attempted suicide problematizes his belief in the female survival instinct. If the woman has an inborn strength, it means she can withstand any form of violence and still prevail. Why bother, then, to analyze and critique violent institutions? Imamura does not necessarily criticize violence from a feminist standpoint, but his relentless pursuit of accumulated details reveals many intersecting forms of patriarchal discipline.

Sin becomes inscribed on the female body both through the force of male desire and through any manifestation of female sexual pleasure and agency, as the scenes of Sadako's flashbacks have shown. The entire moral responsibility for sexuality is placed upon the female body and the pollution of rape becomes the woman's shame. The objectification of the female body as the site of male desire causes a painful split between the woman's body and her subjectivity. It disciplines the body through violence and this discipline alters the female self who allows her body to be objectified. At the moment of rape by Hiraoko, Sadako's body has already been inscribed by previous acts of violence that suppressed her sensuality and objectified her body for male desire.

Instead of choosing to die and thus destroying her body inscribed through sexual shame and violence, Sadako undergoes a wholesale transformation due to rape that helps her survive the power of the patriarchal family. Through her refusal to take upon herself the shame and guilt of rape, Intentions of Murder challenges the naturalization of the female body as guilty for its own violation and questions the social precept that the woman's death will wipe away the crime. The rape is kept secret because of its potential destruction of her precarious social status, but the harassing relationship that follows helps Sadako further understand her inferior 
position within the patriarchal household. Her attacker comes back, claiming that he loves her, and ignores her manifestations of revulsion and disdain. His fantasy of romance constructs a beautiful love story out of rape, and he blackmails her with his silence about raping her. The harm of rape as a destruction of the woman's status helps the victimizer by giving him renewed power over his victim. Hiraoko proposes to Sadako that they run away to Tokyo together, and he starts talking to her, showing his weakness and gradually becoming more affectionate. She hesitates but realizes there can be no future with him, and in order to escape his stalking she plans to poison him.

The harm of rape in this film is mainly connected to social status, but in a twisted way. Sadako becomes a renewed victim of violence as Hiraoko blackmails and stalks her, and she must hide her bruises from her partner Koichi and his mother, who scold her for being so clumsy and dim-witted. Her status as a maid and sexual object do not entitle her to pity or justice. She also defies the social rule that required "shamed" women to commit suicide because she wants to live for her son. As she becomes aware that her relationship with Koichi is not very different from her relationship with Hiraoko, she decides both to kill Hiraoko and to sue Koichi's family for taking away her son. Although on the surface the film portrays the gradual transformation of rape into a problematic love story, it also reveals the struggle of the woman against oppressive circumstances. In the following section I will discuss the ethics involved in Imamura's collaboration with actress Harukawa Masumi, and the aesthetic implications of visual metaphors that associate women with nature and men with technology. 


\section{Visual Metaphors and the Actress as Body}

Faithful to his anthropological interests, Imamura draws a parallel between nature associated with women and technology associated with men. There are two visual metaphors, employed by the film and inserted repeatedly at key moments that represent the gendered opposition between technology and nature: the rushing train, and the caged mouse running wildly on a treadmill. They bring attention to the naturalization of male sexuality as unstoppable and of the female as trapped, powerless nature, respectively. ${ }^{72}$

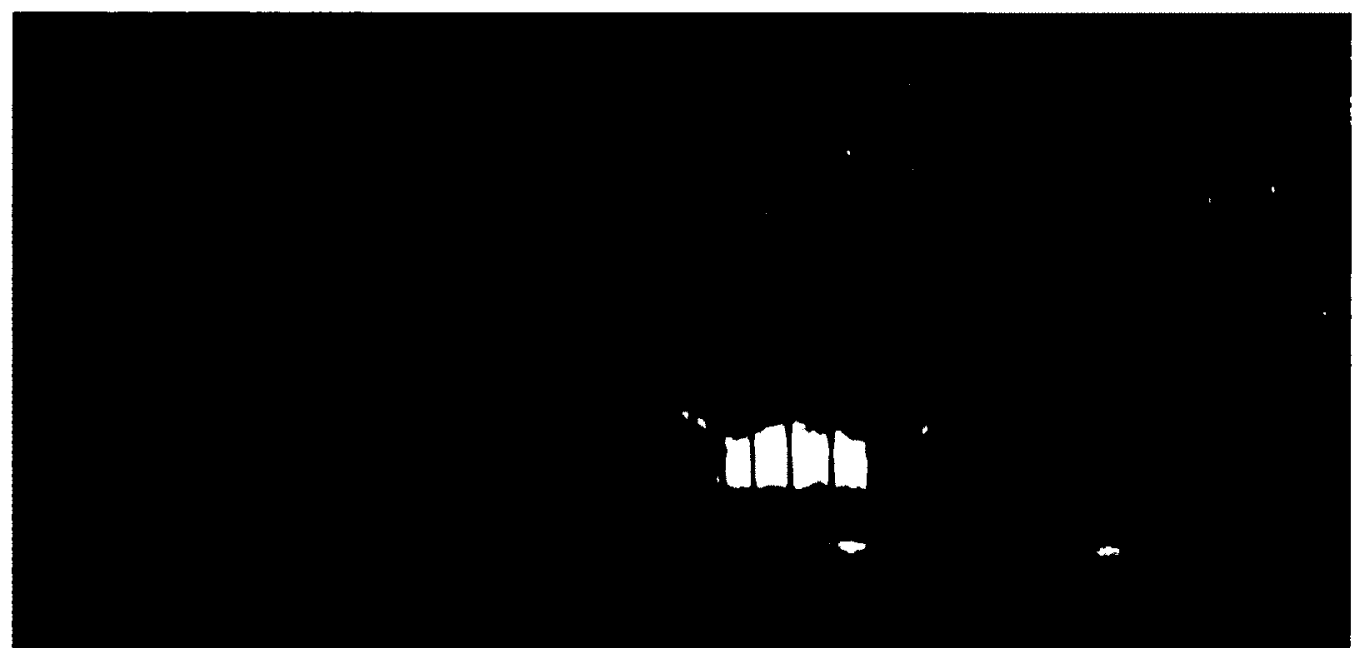

While the first shots of the film showed Sadako in the same frame with the mice, she now looks intently at them, gradually becoming aware of her own entrapment.

As already mentioned, after the thief Hiraoko looks at Sadako's unconscious body, the next shot metaphorically substitutes for the rape a close-up of a train rushing toward the end of the frame, slowed down so as to reveal the brute force of the screeching wheels on the track. Not incidentally, Sadako's house is near the train tracks, and after the rape she runs to throw herself in front of the train. The train functions as a symbol of male desire, enclosure of the woman through domesticity, and relentless patriarchal rule over female honor. The image of the train has a double significance: on the one hand it normalizes male desire as unstoppable, while on the

\footnotetext{
${ }^{72}$ Due to space constraints, I have chosen to focus here on the naturalization of the female body as inscribed by sexuality, leaving out the naturalization of male sexuality as unbounded and unstoppable, although I believe they are interdependent.
} 
other it brings attention to the association of male eroticism with violence and death. The second time Sadako is assaulted, the associated soundtrack is of a train, and one of Sadako and Hiraoko's most famous struggles takes place as they try to push each other off a moving train. One dream sequence shows Hiraoko, who promised to take Sadako to Tokyo, opening the train door and pushing her into the sea. Her body floats in the darkness until it disappears, a sign that she can only exist socially within the norms of male desire.

The visual metaphor of caged mice echoes Insect Woman, in which the female character is paralleled by an insect. In a carefully choreographed frame with two caged mice on the left and Sadako on the right, we see her painstakingly verifying the home accounts and expenses. In a voice-over, Koichi's mother criticizes her for her lack of education. Both her position as a maid in a household that denigrates her and her outsider status as a mistress are parallel to the situation of the caged mice. The image of the caged mice reappears several times to punctuate Sadako's increasingly chaotic situation, until the mice die - a reminder of the transformation Sadako herself will undergo as she becomes aware of her own cage. The mice function to highlight both Sadako's captivity and the futility of her efforts to escape abuse and domination.

In addition to these two visual metaphors, which evoke overwhelming male sexuality and the contained female body, respectively, the body of the actress Harukawa Masumi reveals intricate layers of disciplining norms pertaining to the institution of cinema. When Imamura was looking for an actress to play Sadako in this film, he famously referred to the image of her in his head as that of a woman of "medium height and weight, light coloring, smooth skin. The face of a woman who 
loves men. Maternal, good genitals. Juicy." 73 He interviewed more than thirty actresses for the role and even went with his crew to recruit an amateur actress from a strip club. ${ }^{74}$ The director decides on the casting of an actress according to her bodily qualities - a situation that reflects social and institutional relations of subordination, with male directors achieving their vision through the female body. This hierarchy in the institution of cinema echoes the social placement of women according to their bodily attributes that is presented in the film. Imamura wanted to cast the quintessential countryside woman, lacking affectation and intellectual properties, a woman who feels and acts through her body alone. Dave Kehr has summarized very well Harukawa's acting: "What she does have is a staunch physical presence, a body that insistently communicates its own weight and shape. She is sexual without being in the least sensual-sensuality would require a self-consciousness, a cultivation, she could never possess." 75

Ironically, the cinematic image perpetuates the sexualization of the female body, since the actress and the character become one in the film in order to embody the director's vision. Harukawa's plump body gives a humorous accent to serious scenes such as Sadako's attempted suicide, thus distancing spectators from her misery. However, as Satō Tadao mentions in an interview with Imamura, you never know whether the character is really slow-witted and obtuse or whether she simply appears so in the eyes of the other characters. ${ }^{76}$ This ambiguity is not unrelated to the ambiguities surrounding the meaning of rape. One cannot know how women really are, precisely because it is impossible to demarcate clearly between their subjectivity and the influence of power norms.

\footnotetext{
${ }^{73}$ Imamura, Imamura Shōhei no eiga, zensakuhin no kiroku [Record of all Imamura Shōhei's films], (Tokyo: Haga shōten, 1971), 101.

${ }^{74}$ Katori, Imamura Shōhei densetsu, 198.

${ }^{75}$ Kehr, "The Last Rising Sun," 76.

${ }^{76}$ Satō, Interview with Imamura Shōhei on Criterion DVD.
} 
The association of the male with technology and of the female with nature, instinct, and the body is replicated through the cinematic institution, in which men manipulate and create their own vision through the acting bodies of the actresses. This association projects the woman as embodied nature, a form of sexual difference critiqued by Grosz. She points out that the female body has been naturalized as the site of eroticized sexuality and has been defined as nature existing prior to cultural institutions, whereas the male body has been "disavowed as the incorporeal instrument of an ostensibly radical freedom."77 The ability of men to pursue their own desires for maternal care, sexual pleasure, or artistic expression through the female body is indeed a valuable form of male freedom.

Through the mediation of subjective memory in the form of flashbacks and the exploration of subjective states of mind through bodily imagery, the film constructs rape as an ambiguous form of sexual violence that reveals other forms of systemic gendered violence. I have analyzed rape as a literal, bodily struggle between the power of the patriarchal institutions and female subjectivity that problematizes larger issues of gendered embodiment in postwar Japan. I have also suggested that Intentions of Murder reworks two scenarios that naturalize rape: first, that the female body is guilty by luring men with its sexual presence, and second, that women are secretly enjoying the violence against their bodies because of their innate masochism. The feudal extended family and the power of male sexuality inscribe the postwar Japanese female body according to norms of male desire, an inscription that is never complete as it is negotiated by female subjectivity. By maintaining an ambiguous position between representing these naturalizing scenarios of the sexual female body and undermining them, Imamura's film requires us to pay attention to the complicated,

\footnotetext{
${ }^{77}$ Butler, "Contingent Foundations," 16.
} 
shifting model of the body's status as interface between inner subjectivity and cultural institutions. My reading of the film has analyzed the power relations that construct Japanese female sexuality at the intersection of gendered and class relations of subordination. The sexual body is not the stable natural ground for a culturally marked gender but is itself a fluid, historically marked frontier between cultural norms and individual subjectivity.

Realistic and Avant-Garde Tropes-The Desire for Cinema as an Objective Scientific Tool for Grasping Women's Reality

Both Insect Woman and Intentions of Murder adhere to principles of neorealism in thematic and in technical approaches but the realist traits are counterbalanced by avant-garde tropes like freeze frames and voice over, symbolic associations and relentless close ups. The duality of filming technique parallels at a formal level Imamura's use of cinema as a scientific, anthropological tool for understanding reality. I will analyze here the duality of these approaches and how they contribute to the scientific gaze meant to define female bodies on one hand and the look as the recognition of women's alterity. As Dave Kehr has succinctly put it, "this is a documentary style that pushes toward symbolism-a reality that shares the frame with its own analysis." ${ }^{78}$ The documentary style constructs the female as subject, while the avant-garde techniques show Imamura's participation in the ability of the gaze to contain and define.

The theme of both films is concerned with social issues in Japan, with the alienation of low class women through the objectification of their bodies. Moreover, both films bear an ontological relationship to reality since they are representations of real women's experiences. The events of the film do not contain a truth by themselves but carry their own meaning and ambiguity that resembles the ambiguity and

\footnotetext{
${ }^{78}$ Kehr,"The Last Rising Sun," 77.
} 
complexity of real life events. ${ }^{79}$ Through location shooting, synchronous sound, high contrast lighting, static camera, long takes and a script based on a real story the film conforms to Bill Nichols' definition of neo-realism as the technique working "less to subordinate characters to the great narrative machinery of the dramatic rise, climax and resolution, than to suggest an autonomy to individual lives that happened to contain small dramas of their own." ${ }^{80}$ Realism means here both a concrete representation of real locations and bodies on one hand and the expression of the world in its essence, more specifically grasping women's bodily experiences on the other hand. The emphasis is on the detachment of the camera that aims to describe characters interacting with their environments without providing identification with them. As Kehr suggests, "Imamura wants to get close enough to study but not close enough to be seduced." ${ }^{81}$ Spectators are not invited to love or hate the characters but to face the full dimension of their humanity.

Imamura aims to create films capable of distinguishing marginal people's experiences from the discourse of the nation state and these films are not a reflection of the Japanese woman's life but a reflection on her life. ${ }^{82}$ In other words, the film portrays various experiences that reflect on the process of becoming a woman. The long takes, synchronous sound and location shooting perform an ontological relationship between the film and the real by constructing a profound sense of verisimilitude that complements through cinematic technique Imamura's preoccupation with understanding reality. He believes in the power of reality (both in terms of locations and the bodies filmed) to reveal unexpected meanings to the

\footnotetext{
${ }^{79}$ See Bazin, What is Cinema? Vol II, tr. by Hugh Gray (Berkeley: University of California Press, 1971).

${ }^{80}$ Bill Nichols, Representing Reality: Issues and Concepts in Documentary (Bloomington and Indianapolis: Indiana University Press, 1991), 167.

${ }^{81}$ Kehr, "The Last Rising Sun," 74.

${ }^{82}$ Mulvey, Death $24 x$ a Second: Stillness and the Moving Image (London: Reaktion Books Ltd. 2006), 158.
} 
camera. He authenticates the semi-fictional world of the film with realistic techniques. Synchronized sound adds a sensation of immediacy and presence, while long takes have their own restrictions and charms by letting the action unfold and placing greater emphasis on the actors. ${ }^{83}$ Each scene relies on the bodily manifestations of the actors and their emotional expressions that the camera captures through deep focus and long takes. Editing is used to mark the passage of time between events but the events themselves are portrayed through long takes, panning and tilting, many times preserving the real duration. The realist techniques of the films create a mode of visuality based on the look as the effort to represent women's alterity.

Imamura was open to actors' improvisation, the nuisances and surprises of location shooting and the raw feeling of synchronous sound recording. It seems as if his desire for scientific objectivity transfers upon the camera the ability to capture aspects of life like an instrument devoid of subjective intervention. He wants to turn the camera into a microscope of real bodies and affects but this desire much like Bazin's idealist vision of a "total cinema" is countered by his own subjective presence and intervention that guides the overall meaning of the film. ${ }^{84}$

Both Insect Woman and Intentions of Murder defy a neat genre categorization through the presence of freeze frames and theatrical voice over, avant-garde, theatrical devices that stops the flow of the narrative and defy the authenticating, realist representation. The freeze frame has multiple functions in the film: to mark the passage of time, to offer access to Tome's emotions and to put spectators in a critical position to the fictional world. Mihalopoulos offers an interesting reading of freeze

\footnotetext{
${ }^{83}$ Imamura, Eiga wa kyōki no tabi de aru, 118.

${ }^{84}$ See Bazin, "The Myth of Total Cinema," In Film Theory and Criticism: Introductory Readings, eds. Leo Braudy and Marshall Cohen (New York and Oxford: Oxford University Press, 1999).
} 
frames, as "snapshots of Tome's internal appropriation." ${ }^{, 85} \mathrm{He}$ argues that the freeze frames punctuate moments when Tome's subjectivity submits to disciplining norms. I would add that they are also highly stylized expressions of Tome's emotion revealed in the form of a recited poem against a static image of her body. The image stops for a moment making place for the woman's voice as a representation of inner feelings. When her lover at the mill union leaves her, the image shows a medium close-up of Tome crying on the river bank and washing her face in the water: "my man is gone/I'm all alone gazing at the river." ${ }^{, 86}$ After Tome's initiation into prostitution and her defiance crushed by the need for money the image freezes on her counting the money with a voice-over recital: "for the sake of my child /I spur my body on to toil/I count my money through bitter tears." ${ }^{, 87}$ Mihalopoulos suggests that the freeze frames "highlight how the interested and impersonal forces of the family, nation-state and capital steal Tome's body and encode it to be a good daughter, dutiful Japanese subject and ruthless business woman." ${ }^{, 88}$ However, his explanation does not cover the various instances of the freeze-frames. These cinematic means of emotional expressions produce a double distancing that prevents identification. First the interruption of the acting body and second, the poetic structure of voice over are avant-garde techniques that put the spectator in a detached position when viewing a melodramatic situation that as a rule invites empathy and identification. Insect Woman is constructed according to Richie as a "story-line actualite," with distancing devices like freeze frames and irony meant to place the spectator in a critical position." Emotion is rendered through Hidari's powerful performance and through the voice in the freeze frames rather than through visual techniques.

\footnotetext{
${ }^{85}$ Bazin, "The Myth of Total Cinema," 282.

${ }^{86}$ Insect Woman.

${ }^{87}$ Ibid,

${ }^{88}$ Mihalopoulos, "Becoming Insects," 282.

${ }^{89}$ Richie, "Notes for a Study of Shōhei Imamura," 20.
} 
In an interview with Satō Tadao on the Criterion version of the film Imamura suggested that he chose Hidari for the role because of her formidable bodily energy (she graduated from a sports college). ${ }^{90}$ This energy is represented in the film as a powerful will to fight adversities and to appropriate norms of survival but it is also a symbol of a wasted effort since no matter how well Tome learns to conform to the objectification of her body, other norms appear and other betrayals happen. The freeze frames as distancing devices put Tome's emotions under microscope, suggesting a "cold, scientific detachment and an enforced, self-protective distance." 91 They act as a form of scientific gaze meant to penetrate and define the secrets of the woman.

The refusal to create conditions of identification runs counter to the form of cinematic pleasure inherent in Hollywood classical cinema and criticized by Laura Mulvey as expression of the male gaze but the scientific gaze does not have less power. Whereas the former defines female bodies in term of male desire, the latter defines and confines the so-called truth of the female bodies. The filmmaker's perception of women is disguised under the supposed objectivity of the anthropological/scientific gaze. However, the scientific gaze reinforced by distancing devices is balanced in this film by Imamura's genuine desire to understand women through his realist techniques. His use of the camera alternates the look with the gaze, the former governed by curiosity and respect while the latter is governed by the power to contain and define inherent in the scientific approach.

The combination of neo-realist techniques with avant-garde means of distancing parallels the duality inherent in Imamura's anthropological approach. He wants to use the camera as an objective instrument in order to understand aspects of

\footnotetext{
90) Tessier, "Shōhei Imamura Interview," 61.

${ }^{91} \mathrm{Kehr}$, "The Last Rising Sun," 74.
} 
reality but he is also subjectively intervening to guide the spectators' attention and to assert the power of the scientific gaze to define the ways in which the female body is disciplined by institutions. The male gaze in this case is not underpinned by pleasure as Mulvey has defined it. It is instead present through the scientific desire for objectivity.

The openness towards reality performed by his realist techniques parallels the negotiation of power between Imamura as a male filmmaker and the filmed women, but his allegiance to a scientific gaze is haunted by power. Through the camera position and the freeze frames we are omniscient, detached spectators to the two women's life dramas but through location shooting, long takes and synchronous sound we are also invited to observe nuances and details of the real life struggle between a woman's subjectivity, her sense of worth as a human being and the objectification of her body. As Bazin has noted, there is an ethical link between reality and the artistic impulse of cinema, a link that is present in Insect Woman through realistic techniques. ${ }^{92}$ However, this ethical link of using the camera to look better is accompanied by the power of the scientific gaze to contain and define women. Imamura acknowledges women's alterity and his films try to represent female subjectivity without personal intervention but they are nevertheless haunted by the power of scientific gaze.

\section{Conclusion}

In both Intentions of Murder and Insect Woman Imamura wanted to highlight women's strength and resilience, an aspect that led theorists like Desser and Satō to

\footnotetext{
${ }^{92}$ See Bazin, "The Ontology of the Cinematic Image" in Film Theory and Criticism: Introductory Readings, eds. Leo Braudy and Marshall Cohen (New York and Oxford: Oxford University Press), 1999.
} 
characterize him as a feminist. ${ }^{93}$ Moreover, Imamura claimed that the women he portrayed in his films were revealing the underlying forces that shaped real women. "Just look around you at all Japanese women. They are strong and they outlive men." 94 However, this strength does not mean that they change their oppressive circumstances but that they appropriate them. I argued in this chapter that the films are not feminist because they describe female strength but because they reveal the norms that restrict women to their sexual bodies. The feudal system of land property, female exchange, and family hierarchy, the gendered unequal economic system, the prostitution system and the supremacy of male sexual desire, all discipline women by pinning them down to the sexual or reproductive potential of their bodies. These power technologies lead to techniques of the self, where women come to define themselves through the sexual or maternal potential of their bodies.

The films open up space for the presence of female subjectivity but at the same time they partake of the power of technology versus the female body through the scientific gaze. The cinematic representation of the female bodies shifts between the look marked by realist strategies and the scientific male gaze underpinned by avantgarde tropes. Imamura negotiates his power position versus women as male director through his efforts to represent female embodiment in a heteropatriarchal system. He performs a radical critique of Japanese society in tune with other New Wave directors while also offering an insightful analysis of women's sexuality.

${ }^{93}$ Imamura, Eiga wa kyōki no tabi de aru, 92.

${ }^{94}$ Quoted in Audie Bock, Japanese Film Directors (New York: Kodansha International, 1978), 292. 
Chapter Three. The Female Body as Boundary of the Nation: Embodying the Postwar in Imamura Shōhei's Documentaries: The History of Postwar Japan as Told by a Bar Hostess (Nippon sengoshi, madamu Onboro no seikatsu 1970) and Karayuki san, The Making of a Prostitute (Karayuki-san, 1973)

There is a complex relationship between actual women's bodies and the dangers women face and nationalist discourse using representations of women's bodies to mark national or communal boundaries. Here, policing the boundaries, too easily becomes the policing of women's bodies and relations with 'other' men and women.'

The two documentaries I will explore in this chapter bring to the forefront Imamura's technique of experimenting with reality and his desire to represent women's real experiences. I will highlight here the points of convergence and conflict between women's memories of personal experiences and Japan's official history while problematizing the documentary's role in the formulation of an ethics of filmmaking. National history functions to a certain extent as a system that regulates and coerces individual experience but at the same time individual experiences can also reveal the constructedness of the nation and the power of official discourse to marginalize and erase different lives. Both documentaries use the voices of women and their bodily experiences to counteract the homogenizing discourse of national identity and to reveal the placement of the female body as the sexual boundary of the nation. I will follow the fractures and the encounters between national discourse and personal experience, between bodies and images, ethics and aesthetics in The History of Postwar Japan as Told by a Bar Hostess and Karayuki san, The Making of a Prostitute. As Isolde Standish suggested, "these films center on a dialectic in which historiography is juxtaposed to the physical embodiment of history through

\footnotetext{
' Jan Jindi Pettman, "Boundary Politics: Women, Nationalism and Danger," In New Frontiers In Women's Studies: Knowledge, Identity And Nationalism, eds. Mary Maynard and June Purvis (London: Taylor and Francis e-Library, 2005), 187-203, 192.
} 
consciousness." My central questions will be the following: What are the points of encounter between national official discourse and female embodied experience and how do the films articulate the personal as political? What are the cinematic strategies used by the films to construct an ethical, feminist discourse about women's reality close to the oral histories written by feminist historians in Japan?

I will start my analysis with the second question, arguing that the codes and conventions of documentaries are essential for understanding the politics of embodied representations. There are two formal aspects of the films that create a more ethically engaged representation of women's reality than the one present in Imamura's fiction films about women. The first aspect of both films is the visual embodied presence of the filmmaker, a taboo of the cinematic apparatus in fiction film (unless the filmmaker is an actor). The embodied presence of the director brings together the structure of the face-to-face interview with the distancing presence of the camera, successfully combining the gaze as a form of power and the look as a mutual negotiation and dialogue. The second aspect is the interplay between the visual power of images as markers of verisimilitude and the sound of women's voices as testimonies of personal experiences. Both films perform a critique of the predominance of the visual as part of the dominant national discourse, giving more weight to women's voices and thus constructing oral histories. In the following part I will analyze the role played by the embodied presence of the director in the construction of an ethical style of filming as mutual engagement.

\section{Embodying the Director}

Both films are representative of what Bill Nichols calls "interactive" documentaries that make visible the embodied presence of the filmmaker and the

\footnotetext{
${ }^{2}$ Standish, Politics, Porn and Protest, 116.
} 
sound/visual recording equipment. ${ }^{3}$ Their structure is of face to face encounter between Imamura and the two women he interviews, creating a situated presence and a form of knowledge as oral history that Imamura contrasts to the historical discourses of the nation. "When the interactive film takes the form of oral histories strung together to reconstruct a historical event, the reconstruction is clearly the result of assembling these discrete pieces of testimony. ${ }^{4}$ The testimonies of the two women reconstitute their own experiences of Japan's modernization, defeat and Occupation revealing the profound gap between the nation and marginalized women's lives, but also the intricate connections between them. This structure of the two documentaries allows for a close reading of the politics of encounter between the embodied director and the two interviewed women.

In both films we literally see how the director sees his subjects, although in The History of Postwar Japan we are only visually aware of the presence of the filmmaker in the signing of the contract for the film. Unlike Karayuki-san where the cinematographer photographs both Imamura and Zendō, in The History of Postwar Japan, the camera is both a mechanical object and an anthropomorphic extension of the director. Imamura is placed with his back facing us, approximating the position of the camera. The dialogue between him and Akaza Emiko develops across the axis of the camera's line of vision. What is important about the interventional gaze is, as Nichols observed, the fact that "the camera abandons the precondition of distance, transforming the detachment of the gaze into the involvement of the look." ${ }^{5}$ The director enters "the same plane of historical contingency" as his subjects, abandoning the safe distance of the camera gaze," while "textual authority shifts toward the social

\footnotetext{
${ }^{3}$ Bill Nichols, Representing Reality: Issues and Concepts in Documentary (Bloomington and Indianapolis: Indiana University Press, 1991), 44.

${ }^{4}$ Ibid., 56.

${ }^{5}$ Ibid., 85.
} 
actors recruited." His presence is more pervasive in Karayuki-san, where the film is structured like a protracted interview in different locales. In The History of Postwar Japan the director embodies both the gaze of the camera and the interlocutor of the interview as an expression of the ethical look based on dialogue and mutuality.

In these two documentaries the camera self-consciously registers the physical embodiment of the human being manipulating it, while at times the director himself is located under the camera's gaze. The interview structure brings Imamura close to the two women by overlapping the technological gaze of the camera with the human look. In that sense, the embodied presence of the director produces an ethics of encounter specific to the interactive documentary mode. This convention is a visual marker justifying Imamura Taihei's point that "documentary film is not a document of mere exterior world events through the medium of film, rather it must be a record of-and furthermore, an expression of human knowledge." 7 The concern of this scholar is that the objective recording power of the camera has reinforced the definition of the documentary as evidence and source of knowledge in contrast to fiction film, thus making invisible the subjective presence of the filmmaker. These two documentaries reveal not only women's lives but also the director's subjective presence and his value judgments.

Although the director reduces the distance between him and the women and he even reveals the backstage of the filmmaking process, the interview structure is not completely innocent. Reminiscent of Michel Foucault's idea of confession, it maintains hierarchies, implanting "technologies of knowledge" that promise a sense of

\footnotetext{
${ }^{6}$ Nichols, Representing Reality, 86, 44.

7 Imamura Taihei, "A Theory of Film Documentary," In Decentering Theory: Reconsidering the History of Japanese Film Theory, Review of Japanese Culture and Society, tr. by Michael Baskett (Tokyo: Josai University Press, December 2010), 52-59, 55.
} 
plenitude and self-sufficiency." 8 Private confessions especially about sexual experiences are expressions of the power structure's attempt to contain experience through knowledge. ${ }^{9}$ While this caution is valid in the analysis of Imamura's documentaries, it will be too limiting to subsume his whole project to an expression of power. It is true that the interviews posit him more as the source of knowledge and authority than as a participant into a dialogue. However, by bringing marginal women's experiences to the forefront, Imamura explores how the most personal and intimate experiences are caught in historical change. In that sense, women and more specifically their embodied experiences are made participants in the formation of the historical world. His films reconstitute women's lives as oral histories that challenge their marginalization by official historical discourse and perform a feminist documenting of women's history. In the following part I will analyze the interplay between the female voice and the authority of visual records.

\section{Documentary as Oral History: Female Voice and the Deconstruction of Visual Truth}

The films deconstruct the ability of the documentary to visually represent historical truth by introducing conflicting perspectives. They highlight the conflict between the value of images as objective, indexical recordings of historical truth and women's voices that reconstruct personal memories at times in conflict with the images. The thematic dichotomy the films enact between national historical discourse and women's personal experiences is replicated at a cinematic level by the dichotomy between the official authority of images and female voices. The same problem has been raised by feminist historians in Japan. Ueno Chizuko has shown that "the greatest challenge facing women's history is finding ways to allow the silenced voices

\footnotetext{
${ }^{8}$ See Foucault, History of Sexuality, tr. by Robert Hurley, vol. 1 (New York, Vintage, 1990).
} 
to speak. This is why women's history turned to oral history." ${ }^{10}$ Imamura's documentaries open up the space for women's voices that reconstitute their embodied experience of history and this strategy brings him close to the perspective of feminist historians. However, the writing of women's history as oral history is not without problems as Ueno pointed out. Testimonies are characterized by lapses of memory, selective memory, inconsistencies, and the intervention of the present in the narratives about the past. ${ }^{11}$ The subjective version of history filtered through the emotional consciousness of women raises questions of objectivity, value and truth that are also valid for national discourses. Positivist national historiography is haunted by the same subjective interventions, for example the lapses of memory about the Nanjing massacre, the privileging of political events as opposed to everyday experiences, the narrative of historical progress, etc. ${ }^{12}$

\section{The Voice as Source of Interiority}

Karayuki-san relies solely on the testimony of Zendō Kikuyo without transforming her memories into images. The voice dominates the image sustaining its presence through shots of various locales of the interviews. There are no flashbacks of events that characterize fictional representation of memory, no visual reconstitution of the past and consequently, no visual pleasure, an issue I will explore more when I analyze the film. Imamura's own voice-of-God commentary is used less as an explanation of events and more as an explanation of his subjective implication in the film's topic. His commentary explains the larger political implications of Japan's globalization on women who were trafficked abroad to serve as prostitutes, an issue I will consider in my analysis of the film. However, these commentaries are brief and

\footnotetext{
${ }^{10}$ Ueno Chizuko, Nationalism and Gender, tr. by Beverly Yamamoto (Melbourne: Trans Pacific Press, 2004), 123.

${ }^{11}$ Ibid., 123-124.

${ }^{12}$ Ibid.,
} 
the main part of the film develops as a dialogue. As Bill Nichols has shown, "the reinstitution of direct address through the interview has successfully avoided some of the central problems of voice-over narration, namely, authoritative omniscience and didactic reductionism."13 The structure of oral history confronts footage with women's voices, critiquing the authority of the documentary to reveal social truth as well as the omniscient authority of the filmmaker.

The History of Postwar Japan opposes Akaza's testimony about her experience of postwar history with newsreel images of various important historical moments. The opposition is also present in the newsreel themselves, which show a nation torn apart by mass demonstrations and great civil unrest. Newsreel footage showing a confident MacArthur descending from the plane is associated with the official discourse of Occupation as democratic reform. The next shot shows newsreels of the farmers' protests against the expropriation of their land by military bases and the violence against peaceful protesters. The truth about Japan's postwar years is a highly contested terrain divided along subjective views. In that sense, the film does not necessarily confer authority to the woman's voice as being the representative of truth but it rather deconstructs the highly contested notion of historical truth. The film highlights the discrepancy between women's experiences and the official discourses of Japan's postwar history through cinematic ironies. Although the two documentaries are visual representations of women's testimonies, the focus is more on the soundtrack and the oral reconstitution of experience. Kaja Silverman has related the soundtrack to the preoccupation with authenticity and interiority. ${ }^{14}$ The voice is always connected to the expression of inner feelings or thoughts and it is anchored in its embodied source.

\footnotetext{
${ }^{13}$ Bill Nichols, "The Voice of Documentary," In Film Quarterly, vol. 36, No.3 (Spring 1983): 17-30, 23.

${ }^{14}$ Kaja Silverman, The Acoustic Mirror: The Female Voice in Psychoanalysis and Cinema (Bloomington: Indiana University Press, 1988), 42.
} 
unlike the image that relies on the play of surfaces As Robert Stam has argued, when attention moves from predominantly visual expression to a space of the vocal, it becomes a way of restoring voice to the voiceless. He suggests that the voice is a metaphor of seepage across boundaries, in contrast with the "visual with its limits and boundaries and border police." 15 Instead of speaking for women like in his fiction films, Imamura speaks now with women. Their voices reveal female embodiment as the blind spot of history in contrast to official national discourse. Official history marginalized both women and their emotional or bodily life to the realm of nature. The female voice challenges both the power of the nation state and the power of visual images, performing a critique of historical truth. In the following part I will analyze the documentaries' role in the construction of an ethics of filmmaking that negotiate the power of the cinematic apparatus. As Sara Ahmed has shown, "joining a voice to a body complicates what we see, potentially disturbing the terms of cultural difference and revising the possibilities for an ethics of recognition."16

\section{Eroticism and Ethics of the Image}

Paraphrasing Mulvey's argument that through the manipulation of space and time fiction film produces "an illusion cut to the measure of desire," Nichols argues that the documentary produces "an argument cut to ethical, political and ideological measure." While fiction films produce an eroticism (regardless of the presence or absence of erotic images per se) of the image meant to give pleasure to spectators, documentaries aim to produce knowledge about the historical world. The desire to know is far from innocent, being just as anchored in power relations as eroticism. However, in the dichotomy outlined above, documentaries represent the desire to understand reality and to grasp difference, negotiating and even abdicating power.

\footnotetext{
${ }^{15}$ Stam and Shohat, Unthinking Eurocentrism, 214.

${ }^{16}$ Sara Ahmed, ed. Transformations: Thinking Through Feminism (New York: Routledge, 2000), 17.

${ }^{17}$ Nichols, Representing Reality, 77.
} 
Imamura's political and ethical program is to offer a counternarrative to Japan's official discourses of history by recording a doubly marginalized discourse: that of women and of bodily experiences that have been long absent from the rational discourse of official history.

The Postwar History of Japan traces the course of Akaza Emiko's (Madame Onboro's) life in terms of Japan's experiences of defeat and Occupation, problematizing her oppression as a woman and a burakumin (member of the lower caste). The setting is of a spatially and temporally bounded interview that functions both through dialogue and through the contrast between images and the woman's voice and bodily presence. Images function both within the space of the interview as newsreel footage or pictures shown to Akaza, and as the filmmaker's own commentary or symbolism introduced through editing. Karayuki san is a documentary that features an extended interview in different locales of Zendō Kikuyo, a Japanese woman in her seventies from a village near HirŌshima, who was taken into prostitution in Malaysia in the late Meiji period (1868-1912). The purpose of the documentary is to reveal her loneliness and hardships and to critique Japan for marginalizing and abjecting women like her as dangerous to the boundaries of the nation. Imamura stages it as a personalized interview with minimalistic equipment and crew, creating a discourse of sobriety that tries to recuperate the past through locations and interviews.

Both films were made with private funding, an aspect that reveals the director's personal commitment. As he states in an interview with Nakata Toichi, "documentary seemed a better vehicle for my unending desire to get close to people's 
true natures."18 Rather than portraying how people interact with society like in his fiction films, he is trying to understand how women lived their own lives through the constraints imposed on them by social systems. This aspect of documentaries raises a series of ethical questions about the effort to structure the absence of women's real embodied experiences through personal memories. Unlike important historical and social events that were registered in official documents or the visual images of the newsreels, women's personal, intimate events could only be reconstituted from personal memories. The reconstitution shows that even the most intimate aspects of their lives for these women were implicated in larger, social events. Through the recall of events as memories, both films articulate material, real bodies into a "literal embodiment of social practices." 19

Returning to Nichols' comments, the films involve ethical and ideological commitment rather than the desire to offer visual pleasure. The former is the effort to represent women's real lives without imposing a certain meaning on them while the latter is an attack on the unified, homogenous concept of the nation. I will start with an analysis of ethics since it is essential for grasping the gendered relationships between the male director and the filmed women. For Nichols, "ethics can be said to be an ideological mechanism by which those with power propose to regulate their own conduct." ${ }^{20}$ His definition explains the premise of the ethics from the part of those in power but is not far from Lévinas' explanation. Lévinas argues that responsibility for the other is rooted in our subjectivity, formulating ethics as a state of openness towards the other that would allow for genuine intercommunication. Subjectivity is for him manifested first and foremost by moral responsibility for the other, a result of

\footnotetext{
${ }^{18}$ Nakata Toichi, "Shōhei Imamura Interview," In Shōhei Imamura, ed. James Quandt (Toronto:

Toronto International Film Festival Group, 1997), 107-125, 119.

${ }^{19}$ Nichols, Representing Reality, 255.

${ }^{20}$ Ibid., 103.
} 
acknowledging the commonalities of our embodied existence." ${ }^{21}$ We can see in this definition the shadow of the problems raised by sexual and racial differences because they defy embodied commonalities. How is it possible for men to understand women and to bridge the gap of difference?

I argued in the previous chapters that it is no coincidence that Imamura made his films in a period of intense debates around subjectivity. ${ }^{22}$ The collapse of a whole ideological system entailed a crisis of the male subject that could not define itself in terms of the national discourse. This phenomenon explains why the New Wave filmmakers were exploring Japanese identity through the cracks and fissures of the national homogenizing discourse. It also helps understand the interest of these filmmakers in the political dimension of women's bodies. Imamura explicitly stated that he was interested in karayuki-sans because he wanted to interview people abandoned by their country and he was interested in Madame Onboro because she abandoned her own country. He was fascinated by "the strong, dark feeling of someone who abandoned her village and was about to abandon Japan (Nihon wo suteru). ${ }^{23}$ Women's transgression of the boundaries of national identity echoes the ideological transgression of the New Wave generation of filmmakers facing the crisis of national identity and its ideological anchoring of male identity. This crisis of the male subject entailed possibilities of ethical engagement with the Other because of the self-reflexive acknowledgement of the filmmakers' own participation in systems of power that oppressed women. Together with a critique of national ideology they perform a critique of patriarchy and they are better suited to reflect on women's tense

\footnotetext{
${ }^{21}$ Emmanuel Lévinas, Humanism of the Other, tr. by Nidra Poller (Chicago: University of Illinois Press, $2003), 64$.

22 See Koschmann, Revolution and Subjectivity in Postwar Japan (Chicago: University of Chicago Press, 1996).

${ }^{23}$ Imamura, Eiga wa kyōki no tabi de aru, 118.
} 
relationship with national history. The documentaries perform a double function: They critique the homogenizing, official discourse of the nation and they create a space that represents how the most intimate, bodily aspects of women's experiences are related to larger social transformations.

Kaplan formulates a definition of ethics as an intersubjective relation not governed by power. In visual terms she proposes the differentiation between the look and the gaze. The look is governed by curiosity about the other, by closeness and intimacy while the gaze is a one way subjective vision governed by anxiety or desire and constructed as "an attempt not to know, to deny even." 24 All three definitions suggest an equal dimension of encounter and communication of open subjectivities not articulated through power. This ethical dimension is acknowledged by Imamura himself when he reflects on the implications of his interviews with Zendō.

I had to ask her a series of shockingly direct questions. For my part, though, I was less and less sure that I could justify asking her such questions. I had to ask myself whether or not I was exploiting her, whether or not I had good enough reasons to expose her past in public, and whether or not I really understood her feelings. I came to realize the presence of the camera could materially change people's lives. Did I have the right to effect such changes? Was I playing God in trying to control the lives of others? ? $^{25}$

This soul searching comes to Imamura through the intersubjective exchange ensuing between these women and himself as a director. He becomes aware of the power of the camera to control the subjects within its gaze. This awareness of his power position lies at the center of his documentaries, taking us back to Nichols' definition of ethics as a mechanism through which those in power are ready to regulate their power. Although the documentaries did not in any way empower Imamura since they were not funded by an institution and they did not bring him

\footnotetext{
${ }^{24}$ Kaplan, Looking for the Other, xvi.

${ }^{25}$ Nakata, "Shōhei Imamura Interview," 120.
} 
financial or artistic success, the very fact that he is the one holding the camera and formulating the questions, structures his dialogue with the two interviewed women in a problematic way. The filmmaker's intention to construct the films as a dialogue governed by the look is tampered by the presence of the technological apparatus that structures his ethical intentions in terms of gaze.

In my analysis of Insect Woman I argued that Imamura turned the gaze of the camera into a scientific object for exploring women's reality, while the look entailed by the film is one of openness and respect. The director negotiates his power position versus women with his desire to open a space for their own experiences. These two documentaries are expressions of the negotiation between the objective gaze of the camera, the male gaze and the look. Nichols has pointed out the dual dimension of camera, as a machine that produces indexical images and as an anthropomorphic extension of the operator's worldview and value. All films are haunted by this duality but few of them problematize it in their diegesis like these two films. Imamura's own presence entails a look at the women, curiosity about their lives and the desire to open a space for their marginalized subjectivity, while the presence of the camera entails a gaze, a one dimensional mode of knowledge close to Foucault's notion of the confessional. The gaze of the camera "supports an epistemology based on scientific principles of mechanical reproduction" tampered by Imamura's empathetic approach that abandons the conditions of distance and unidirectionality through his embodied presence. ${ }^{26}$ As a male embodied presence he has a form of authority over women close to the male gaze but he negotiates it through his desire to let women represent themselves.

${ }^{26}$ Nichols, Representing Reality, 89. 
These two documentaries are the closest approximations of ethical filmmaking among all the films considered in this dissertation. I do not mean to say that they do not involve any form of power but compared to the other films I consider in this thesis and compared to the majority of Japanese films in the 1960s and 1970s that objectify and sexualize the female body, they negotiate both the power relations between the male filmmaker and the women interviewed as well as the objective gaze of the cinematic apparatus. They also parallel the efforts of feminist historians to write the history of women as oral testimonies of personal experiences. In the following part I will analyze Karayuki-san highlighting the relationship between Japan's globalization and women's bodies. I will compare this documentary with Kumai Kei's melodrama based on the testimonies of karayuki-sans in order to highlight the differences between the documentary as a form of oral history based on the ethical premise of authenticating the female voice and the melodrama that visually recreates female experience with the focus on emotion and victimization.

\section{Karayuki-san, Personal Memories as a Discourse of Sobriety}

Upon watching this film my expectations were permanently frustrated by the lack of any fleshy, explanatory flashback that would make visible Zendō's narrated memories and thus facilitate visual pleasure. Imamura himself confessed that it was surprising for him to hear Zendō's blasé tone "I gave up because there was nothing else to do" instead of expressions of grief, anger and despair. I would like to focus in my analysis of the film on the situated, embodied expressions of memory expressed through voice rather than images. Zendō's body is of a kind and gentle seventy three year old Japanese woman that does not bear any visible mark of her long life of abuse and suffering. 
Before I proceed to a closer analysis of the film I would like to mention the history of Karayuki-san in Japan's transnational context. In his well- documented study, Sex in Japan's Globalization 1870-1930 (2011), Bill Mihalopoulos follows the economic and political implications of women being trafficked into prostitution in parts of Asia. Kara is an archaic term referring to mainland China, while $y u k i$ is a suffix of the verb "to go." These women's lives were directly influenced by Japan's encounter with globalization and capitalist modernization. While it is doubtful that all of them were trafficked, they are an example of the strategies sought for by the rural poor as "they adapted to the rapid economic and social changes occurring in Japan from 1870s."27 The Meiji reform unchained peasants from the land and increased mobility, a situation that led many women, especially from the Kyushu area to try to avoid destitution caused by poverty or misfortune by seeking work abroad. However, their mobility was highly marked by gender norms and the majority of them "entered the labor market as things to be sold. “28

The book also analyzes the conceptual transformation of karayuki san within national discourse. Before 1920 s prostitution was marked by an absence of stigma for women, who would be respected as long as they could assure the continuity of the household through their remittances. "They were recognized as a legitimate component of village life, economically, culturally and socially." ${ }^{29}$ However, Japan's modernization and its rivalry with the West in imperialist endeavors made consuls and bureaucrats design these women as "unsightly overseas prostitutes." bureaucratic stigmatization of these women led to a high degree of criminalization and

\footnotetext{
${ }^{27}$ Bill Mihalopoulos, Sex in Japan's Globalization, 1870-1930 (London: Pickering and Chatto, 2011), 17.

${ }^{28}$ Ibid., 126.

${ }^{29}$ Ibid., 35 .

${ }^{30}$ Ibid., 36.
} 
social marginalization, which, in turn, exposed them to a higher degree of exploitation. The claims made on behalf of these women by various interested parties silenced and "disqualified the voices of the poor while simultaneously concealing what was experienced by the women working as overseas prostitutes." 31 This study makes explicit both the economic and social circumstances that led to the phenomenon of karayuki-san and the political implications of Japan's modernization and globalization for these women's lives. Japan's imperial ambitions led to the abjection of these women outside the boundaries of the nation.

Imamura's film addresses precisely what Mihalopoulos critiques: the silencing of these women despite their presence in national discourse. The film restores Zendō's voice but her age makes her memories coalesce into a discourse of sobriety, significantly different from the defiant, rebellious attitude of Madame Onboro. The movie is also strikingly different from the lush melodrama Sandakan Number 8 (Sandakan hachibanshokan bohkyō, 1974) adapted after Yamazaki Tomoko's famous book documenting the life of Osaki, an overseas prostitute. In an interview with Max Tessier, Imamura pointed out that he refused to adapt the novel to film because it showed only the teary side of the problem. "When I met the real karayuki san of my film I had in front of me a women, still very alert, with good morale-a far cry from the "depressing" side of the novel."32

Karayuki san starts with the entrance into the port of Kelang, recreating the trajectory of Zendō's journey, allegedly abducted to work as a prostitute in Malaysia. Imamura's voice-over explains briefly her life history and his commitment to the film project. Resident of the HirŌshima area, Zendō was raised by her brother after her

\footnotetext{
${ }^{31}$ Mihalopoulos, Sex in Japan's Globalization, 131.

${ }^{32}$ Max Tessier, "Shōhei Imamura interview," in Shōhei Imamura, ed. James Quandt (Toronto: Toronto International Film Festival Group, 1997) 57-69, 66.
} 
parents died leaving behind eight children. Her background of dire poverty and caste marginalization (she was also a burakumin) reveals the circumstances of her journey and the ambiguous situation of being kidnapped. As Mihalopoulos pointed out, many of these women were driven by desperation and the hope that they might find a better situation, a situation that greatly helped the trafficking process.

The film edits images of the Malay port in association with Imamura's voice of god commentary that introduces Zendō and explains his intention in the making of the film. "This is the story of an old woman who experienced many hardships as she was abducted from Japan from Meiji to Taisho period to work as a prostitute. I wanted someday to hear and record as history the stories of marginal people like her whose experiences are not recorded in legitimate history texts. (seitō no rekishi)"

An acquaintance took Zendō to a hotel in Kobe to meet a man, who subsequently guided them to a boat where many young women would be locked and taken to Singapore or other locations in Asia. The strangeness of the situation, the lack of friends or relatives and more than that, the lack of a protecting law or space underscores women's compliance. "We cried and protested but we knew we would never be returned so we finally gave up." Without papers and a law to protect them, these women become objects of exchange to the extent that they themselves believed they were mere objects. The man who took them got 600 dollars for Zendō, a sum of money she had to pay back in two, three years of working as a low-grade prostitute.

The camera shortly reconstitutes the location of Zendō's journey and the place where she worked for the first time, as if these spaces could reveal traces of her experiences. The dialogue between Imamura and Zendō reconstitute through words the coherent narrative of a dramatic life, which is now purged of all the emotions 
involved in tragic situations. The dialogue is smooth and at times humorous, creating a sense of being removed from the emotional intensity that must have colored her experiences. Imamura asks her what was the hardest thing in her life and she hesitates, stating that the hardest thing was loneliness and the lack of communication with her relatives. He presses further asking private questions about her involvement in the trade. "Did you experience any sensual pleasure in your contacts with the clients?" The answer comes back almost unexpectedly. "No...not at all. It was a daily thing and sometimes it was unpleasant." I stated above that Imamura was aware that in a sense he was invading her privacy and exploiting her past in order to reveal what he thought was interesting about her life. Her emotions sheltered in the dim places of memory are impossible to reveal. What the film reveals is an oral testimony authenticated by Zendō's embodied presence. Is it the structure of the interview that makes her maintain a discourse of sobriety devoid of any emotional manifestation or is it her age and the coming to terms with her experiences? In contrast to the sobriety and the lack of any reconstitution in Imamura's film, Sandakan Number 8 , made only one year before by Kumai Kei can be said to be its emotional counterpart. In the following part I will compare the differences between the style of documentary and that of melodrama in their treatment of female bodies and emotions.

\section{Emotion versus Truth: Melodrama and Documentary}

The film Sandakan Number 8 is based on the book written by Yamazaki Tomoko who traveled to Amakusa Island in Western Kyushu where she interviewed one former karayuki-san. Both the book and the film focus on the victimization of women working as prostitutes reconstituting vividly the details of their experiences and their feelings. The source of the book is the oral testimony of Osaki, an elderly former karayuki san, whom Yamazaki had met in a chance encounter on her first trip 
to Amakusa. Both the novel and the subsequent film highlight the powerlessness and suffering of the women trafficked to serve as prostitutes. The scenes of Osaki's protest upon being forced into prostitution and her encounter with the first customer are in stark contrast with the minimalism of Zendō's words and the onscreen presence of her seventy years old body. Her words describe a memory that has come to terms with the tragic circumstances of her life.

The context of oral testimony is important since in Sandakan Number 8 , Yamazaki, the interviewer must first win the trust and the friendship of the speaker, while Imamura refers to the great number of women he interviewed before choosing Zendō for his film. ${ }^{33}$ This difference shows Imamura's power position as a male filmmaker versus a marginalized woman. Despite his distance and power position that contribute to the lack of emotional expression in Karayuki san, he is nonetheless moved by her story and intervenes in her life by helping her to come and visit Japan. He is also moved by her kindness and magnanimity wondering if he could reciprocate her emotions through his film. "Was I really able to capture the truth about their lives? Was I writhing over their agony and grief? Was my film able to really show their lives?" ${ }^{34}$ His film becomes an ethical commitment to portraying and integrating into national discourse the bodily and emotional experiences of women abjected beyond the boundaries of the nation.

Sandakan Number 8 navigates space and time through the replacement of testimonial memories with images. It reconstructs very vividly Osaki's life alternating between past and present, Japan and Borneo. This reconstruction revolves around the emotional and bodily experiences that are represented through cinematic eroticism.

\footnotetext{
${ }^{33}$ Nakata, "Shōhei Imamura Interview," 120.

${ }^{34}$ Imamura, Eiga wa kyōki no tabi de aru, 124.
} 
Although the focus is on the suffering of the woman, techniques of color, lighting, camera position and acting create a form of cinematic pleasure based on identification, very different from Imamura's documentary. Osaki is lured abroad as an escape from abject poverty and she works as a maid for a year. The scenes of her first experience as a prostitute reconstructs her emotions of anger, pain and fear. Her pimp reminds her that she must pay back her debt with her body and he starts beating her when she refuses. Shots alternate between medium close-ups and close-ups of the man and the woman's face as they fight fiercely. He finally grabs a stick and we are spared the rest of violence with the next shot of a disciplined, kimono clad body climbing the stairs to the room where Osaki will meet her first customer. The relationship between pain and discipline is made very clear highlighting the fact that bodily violence is the best means of producing docile bodies. In Elaine Scarry's words, the pain of violence is an "unmaking of the world" a trespassing on the interiority of another human being and inscribing it with an external will. ${ }^{35}$ The body is controlled through its inscription with power, in this case, the power of potential violence a pimp has over prostitutes. Similar to Kumai in Sandakan, Imamura's films about women show how immediate bodily violence is sustained by social, systemic gender and class disciplining forms of power.

The sadness of face, the grief in the tears, the anger in gestures and voices, the symbolic objects in the mise-en-scene, are all absent in Imamura's documentary, which creates a radically different discourse about the same experiences. As in Insect Woman and Intentions of Murder Imamura does not aim to entertain but to understand, performing a camera work that produces knowledge. His filmmaking comes close to documenting, echoing Mihalopoulos' belief in the power of objective

\footnotetext{
${ }^{35}$ See Elaine Scarry, The Body in Pain; The Making and Unmaking of the World (Oxford: Oxford University Press, 2003).
} 
study. "The catharctic emphasis on the tragedy of the individual emotionally closes and purges the issue. The stress on victimization implicitly reproduces the notion of the women's passivity. The sentimental moralism and prurient details undercut effective social criticism." 36 This discourse of knowledge is conspicuous in his documentaries marked by ethical, mutual engagement and emotional sobriety. In the following part I will analyze the relationship between Japan's transnational politics and the sexualized female body.

\section{The Female Body as Object in Japan's Transnational History}

Imamura's voice-over commentary interprets Zendō's life through the grid of the economic and political circumstances of the nation. Transnational politics provoke interracial tension, which in Sandakan Number 8 are presented through the fear and terror of the prostitute who transgresses racial boundaries through sex. Imamura highlights through voice over Zendō's status as an object (mono) involved in Japan's export products and boycotted by Chinese together with other Japanese products. "Since karayuki-sans were Japanese products, they were vanguard objects for Japan's development abroad. This is the reason they were the target of boycott." Scorned and reviled by natives when economic and political relations become tense, these women are also rejected by Japan as a source of national shame. The prostitute's status as an object body is involved in transnational politics, a situation also shown in Insect Woman and The History of Postwar Japan. Globalization produces object bodies that are either pushed in a no man's land place (karayuki-san) or bodies that take advantage of transnational politics (Madame Onboro).

What is the place of these women within a national discourse? Unlike Mihalopoulos' study that highlighted various discourses around the prostitutes,

\footnotetext{
${ }^{36}$ Mihalopoulos, Sex in Japan's Globalization, 7.
} 
Imamura investigates their perspective on the nation. Although interned in a camp during the war, Zendō says that it made no difference to her whether Japan lost or not. Her marginal status first as a poor, low caste woman and second as an overseas prostitute severs her relationship to the nation as a citizen. As Moira Gatens has pointed out, the body politic was established through the exclusion of women." 37 However, some exclusions are more radical than others. Zendō's body is marked by class and gender exclusion, epitomized by the abjection of overseas prostitutes. "How do you feel about Japan?" asks Imamura and Zendō responds that she misses it very much. "Did Japan do something for you? Nothing at all." Imamura highlights the marginality of these women while searching for their relationship with the nation. In his view, national politics led to Zendō's experiences and he believes the nation has a moral responsibility. On the other hand, he stresses the emotional attachment of these women for Japan as a place, their loneliness and sense of abandonment. This is the reason he helps Zendō visit Japan and arranges for her reception by members of burakumin group. Nation is in this second sense an emotional entity, a sense of belonging to a place and a community, whereas in the former case the nation is a political, economic formation. I see in this ambiguity a trait that runs through most New Wave directors: a relentless critique of national identity but also the effort to find the hidden, suturing points between individuals and collectivity. This phenomenon is foregrounded in The History of Postwar Japan, which I will analyze in the following part.

\section{Deconstructing the Homogenous National History}

The History of Postwar Japan traces the course of Akaza Emiko's (Madame Onboro's) life in terms of Japan's experiences of defeat and Occupation. As I stated in the beginning of this chapter, the film is an interventional documentary structured like

\footnotetext{
${ }^{37}$ Moira Gatens, Imaginary Bodies: Ethics, Power, and Corporeality (London: Routledge, 1996), 49.
} 
a cinema verité interview. Unlike Karayuki san where the camera is mobile, Imamura chooses a more inventive technique of paralleling the national discourse presented through newsreel footage with Akaza Emiko's words. I will follow the set of binaries: national pitted against individual, the male disembodied national discourse against the female embodied experience, image against words, in order to analyze the film's politics of embodied representation.

Newsreels are present both for us as spectators and for Akaza, while other documentary inserts are only made available to us as spectators. She is a tireless interlocutor, with a passion for speaking and an excellent memory. She mediates our gaze and instead of confirming the images in the manner a traditional voice of god commentary would do, she interrogates and defies them. As Standish points out, "the voice of a burakumin woman throws into uncertainty the tones of authority that a male voice over would do."38

\section{Cinematic Ironies: Kokutai and Nikutai Discourses}

The film employs Eisensteinian montage techniques, deriving many subtle meanings from the juxtaposition of newsreel footage with Akaza's commentary. Mellen observes that Imamura does not judge Akaza but uses instead "cinematic ironies" that contrast her experience with that of the nation. ${ }^{39}$ I will argue that the film critiques both Akaza's limited perspective and the national discourse. Her limitation to personal bodily experiences makes her fail to grasp the larger cultural implications of American Occupation and the influence of various policies upon her own life. She is a partisan of American men because their presence freed her from the racism and poverty she experienced among her own people, as well as the violence of her two

\footnotetext{
${ }^{38}$ Standish, Politics, Porn and Protest, 128.

${ }^{39}$ Joan Mellen, The Waves at Genji's Door-Japan Through its Cinema (New York: Pantheon Books, 1976), 236.
} 
Japanese partners. On the other hand, national discourse, although claiming to represent the truth through the visual weight of newsreels and the voice of god commentary, proves to be fragmentary, contradictory and favoring certain perspectives. I will analyze more closely a few scenes that punctuate with irony the gap between her personal experiences of embodied encounter with American GIs and the encounter between Japan and America through the presence of GIs on Japanese soil.

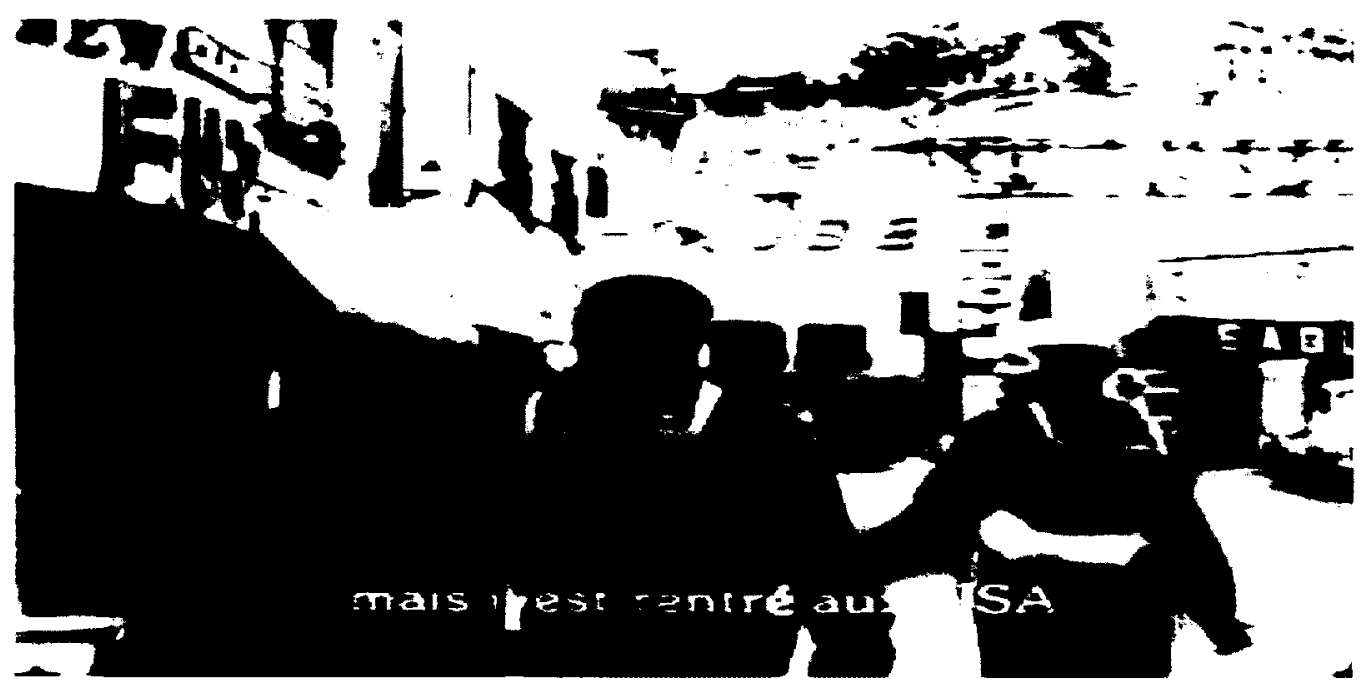

Akaza and her daughter are walking arm in arm with GIs, a ubiquitous scene in the Occupation years but nevertheless one that provoked many anxieties.

To what extent is national discourse a kokutai discourse and what are the connections between kokutai (collective, public, national) and nikutai (personal, private, material)? Douglas Slaymaker ${ }^{40}$ offers a good etymological analysis of the differences between kokutai and nikutai. ${ }^{41} \mathrm{He}$ explains the kokutai as the national body close to a state religion with the emperor at its apex and the people as part of a body space. While this concept was used in the wartime years for establishing Japanese uniqueness and masculine domination after defeat, Japan was feminized and

\footnotetext{
${ }^{+1}$ Slaymaker, The Body in Postwar Japanese Fiction, 8.
} 
turned into a colonial Other. ${ }^{42}$ Kokutai ideology disappeared only to return from repression as the feminized body of the nation. This metaphoric expression of the nation as a body subordinated the will of individuals to the larger will of the nation sublimating the materiality of nikutai. It is for this reason, Slaymaker argues, that there was a strong preoccupation in the postdefeat years with the material body, the nikutai as a form of liberation from the constraints imposed by the wartime regime. ${ }^{43}$ Sexuality emerges as a strong mark of the body, as an energy that defies state control. The film juxtaposes the breaching, the wounding of the national body by the arrival of Occupation forces with Akaza's celebration of the pleasures of the flesh. The female body and the national body come together metaphorically under the sign of U.S. military politics and strategies in Asia. The national body is now in the female position of subordination and lack of agency.

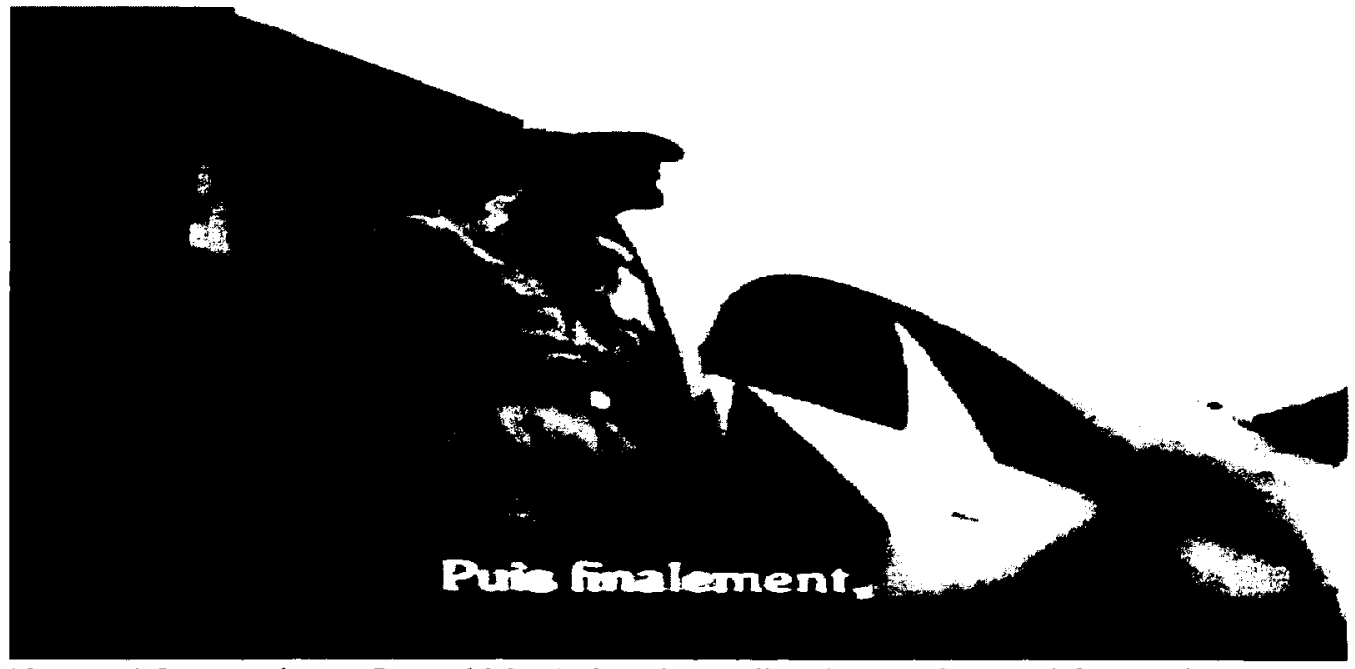

Newsreel footage shows General MacArthur descending from a plane and Occupation troops marching on Japanese soil.

To a certain extent Akaza's words echo the vision of Occupation that American themselves had, as a form of gentlemanly liberation. "They were all kind and gentlemanly... They brought soap and chocolate. There was nothing to worry about. People calmed down." While she and her mother talk about their social

${ }^{42}$ Igarashi, Bodies of Memory: Narratives of War in Postwar Japanese Culture, 35.

${ }^{43}$ Slaymaker, The Body in Postwar Japanese Fiction, 11. 
position, newsreels images of poverty and suffering are inserted. "The conquered Japan suffers" the commentator says against images of homeless, vagabonds, orphans and bodies sprayed with DDT. Her relationship with G.Is structures her response to Occupation in general, as she has vicarious access to America's idealized power and bounty. Through her sexual body and emotional availability she enters a world of apparent freedom through consumerism. Unlike the underlying meaning of US Occupation as subjugation for Japan, for Akaza it means freedom and agency (problematic in its own way). Imamura shows newsreels of massive protests against the presence of US bases and the trespassing of the Sunagawa military base while the voice over of the newsreel comments that farmers in Japan regarded the pillars used to demarcate the bases as "planted in their hearts."

The newsreels of the large demonstration at Yokosuka base on May 301966 show the embittered protests against the docking of a nuclear submarine. In contrast to these images of national subjugation and the suppression of dissent, Akaza muses that she relied on the presence of GIs for her livelihood. The protests of Japanese people against Occupation and especially against the renewed Anpo treaty are futile due to the nation's subordinated position. ${ }^{44}$ In contrast, Akaza finds a form of agency by catering to GI soldiers. Her body marks the volatile boundary of an imagined nation.

The second contrasting editing occurs when Imamura asks about her experience of Occupation. The newsreels show ordered rows of people listening to the Emperor's announcement of defeat, some of them crying. Akaza retorts saying that in her experience nobody cried, but on the contrary, they were all relieved. They didn't say anything out of fear but deep down in their hearts they were relieved. Interestingly

\footnotetext{
${ }^{44}$ The Anpo treaty is a shortened version of the Japanese word for The Treaty of Mutual Cooperation and Security between the United States and Japan, which created an alliance between the two countries despite massive protests by Japanese citizens in May 1960.
} 
enough, Joan Mellen reads Akaza's reaction as an example of how the Japanese really felt, a demystification of defeat. ${ }^{45}$ What I see in this scene is not an example of the real experience pitted against a myth, but rather the presence of the fractured nation into groups with various experiences. The ideology of kokutai starts to crumble under the pressure of dissenting groups.

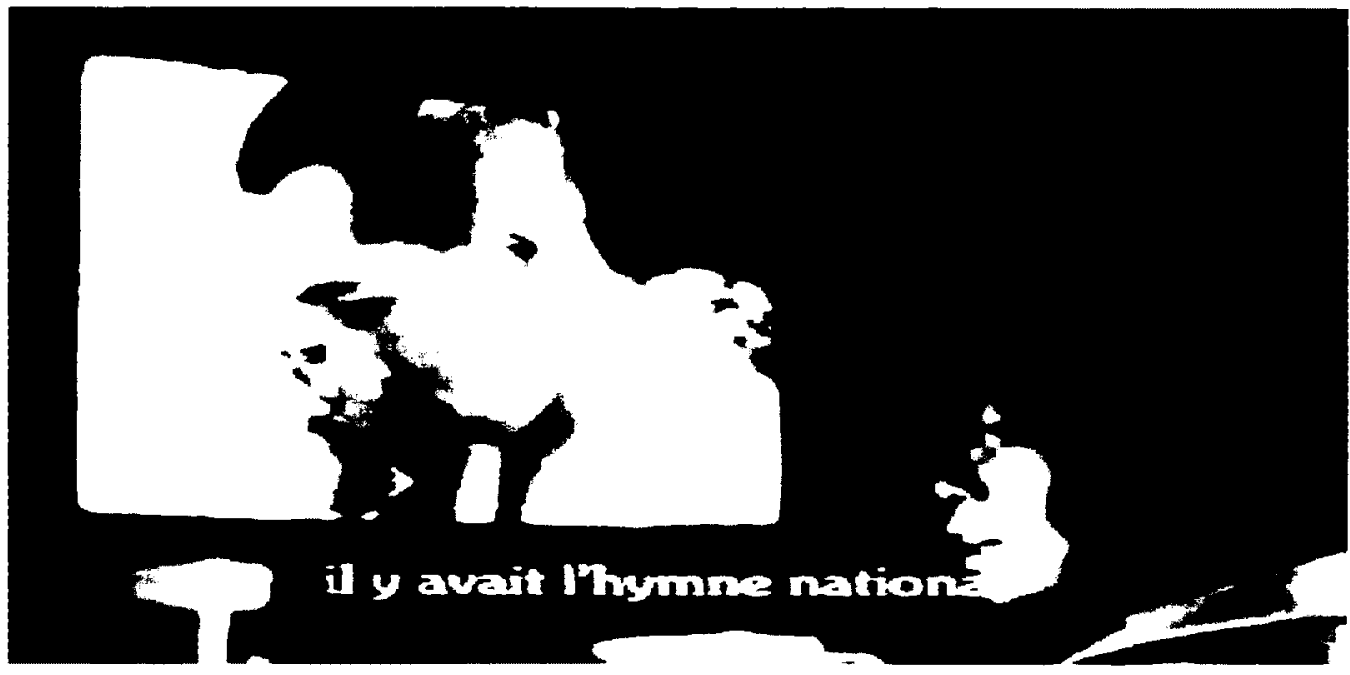

Akaza is watching documentary footage showing people's reaction to the emperor's announcement of defeat. She argues that many looked sad but rather than sadness their emotion was one of exhaustion and relief.

Another ironic juxtaposition is the newsreel showing the wedding of Crown prince with Princess Michiko. She laments the mottainai, the waste of huge amounts of money in the wedding and the reconstruction of the Imperial palace, arguing that with all that money they could have built an orphanage. Her socialist views offer a powerful critique of the imperial system, a critique paralleled visually by the newsreel where a bystander throws a stone at the royal couple. As Imamura stated, "I thought I should describe from Madamu Onboro's perspective the collapse of the Japanese family and its connection with the collapse of the Emperor system." (Imamura, 2001, 63-64) As the newsreel show, the emperor system continues, which, again, raises

${ }^{+5}$ Mellen, The Waves at Genji's Door, 237. 
doubts about the official discourse of the Occupation that claims to have overthrown the emperor system, while actually sustaining it in reality.

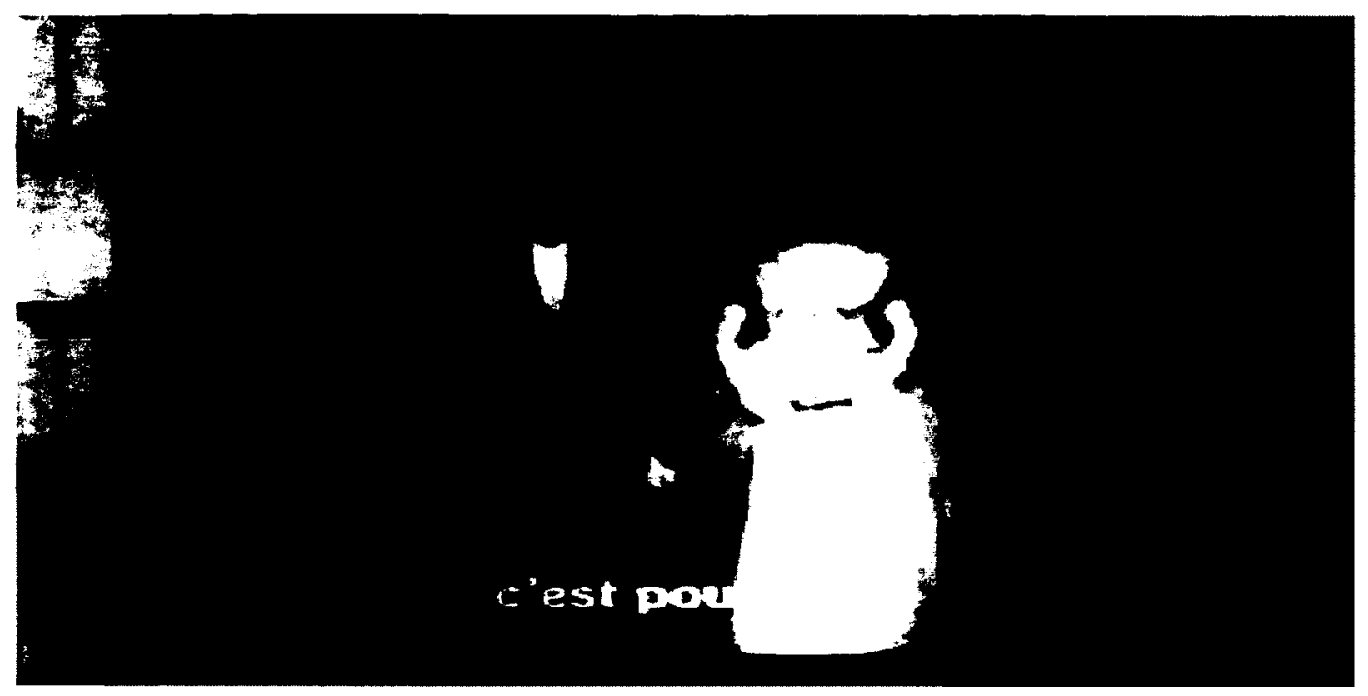

In contrast to the images of the sumptuous wedding of the crown prince, Akaza tells how she explained to her American lovers that the imperial family was not made of gods. "They're Japan's shop window decorations."

The last scene of cinematic irony highlighting the gap between her experience and transnational politics is the moment Imamura shows her pictures of atrocities committed by American soldiers in Vietnam. The pictures are enlarged as close-up images of mutilated corpses while Akaza is protecting the Americans. "Maybe this is a mise-en-scene. I know the Americans. They are nice and gentle. I believe in what I see and what I touch." This immediacy of perception limited to personal experience strikes Imamura as an almost humorous rebuttal of the power of images to represent truth. This scene echoes the scene in Intentions of Murder, when Sadako denies that the pictures taken of her are true. What is relevant about these two scenes is the coexistence of radically different perspectives, both of them equally valid. She did experience American men who were gentler with her than Japanese men but also the American men were U.S. soldiers, embodiments of America's colonial domination. This scene epitomizes a collision of perspectives where Imamura himself partakes of 
the national imagery of US soldiers as representatives of domination, whereas for Akaza they are representatives of a better life and free sexuality.

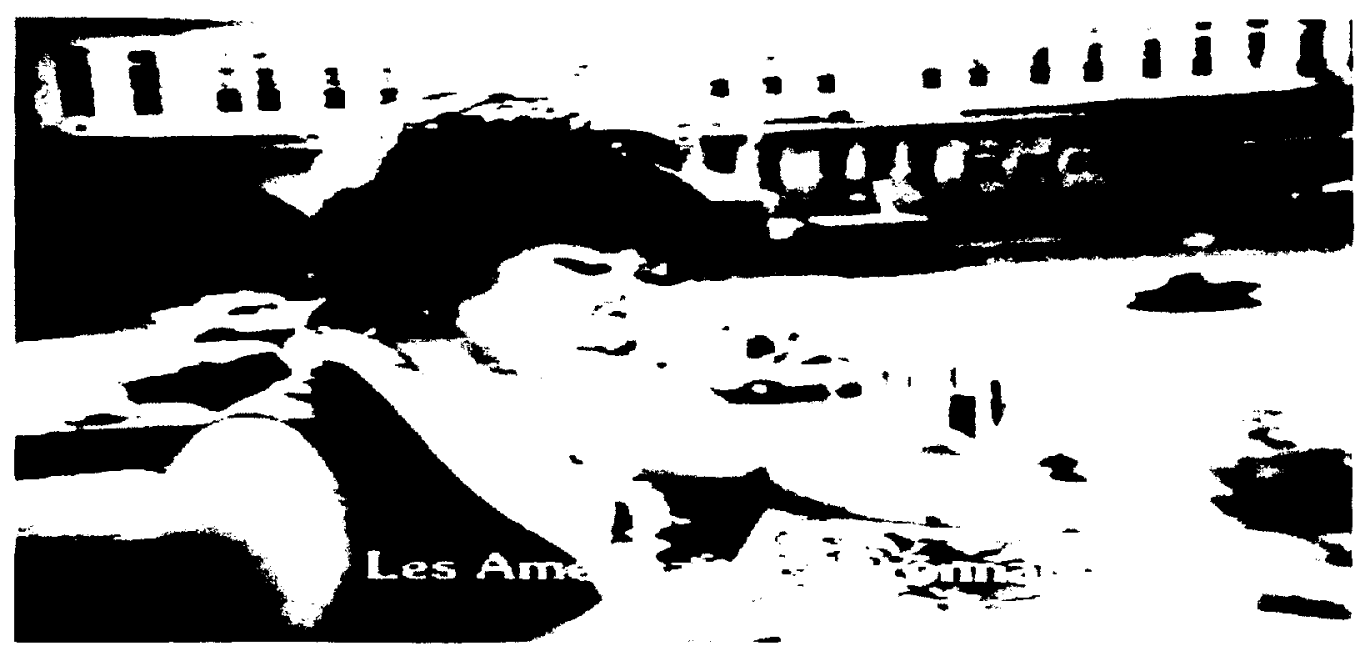

Imamura shows her pictures of atrocities committed by the Americans in the Vietnam war but she denies their reality stating that the Americans she knows are not evil.

These instances of irony not only deconstruct documentary as a cinematic mode that reveals the truth about historical subjects, but they also work in the way suggested by Ueno, to critique the documenting of history itself. Mellen notes that, "Madame Onboro remains unaware that through the newsreels Imamura is contrasting her praise of Americans with the harsh realities of Korea and Vietnam." ${ }^{\text {"46 }}$ Is the purpose of the irony to criticize Akaza and her experientially limited view that overlooks the realities of the American imperial involvement in Asia? It seems to me that the irony works on multiple levels. Akaza's overinvolvement in her sexual adventures, her lack of morality and of any interest in politics, all suggest a limited view dominated by immediate bodily experiences. National discourse and the failure of democracy are also criticized through the pragmatic policies implemented by the Japanese government in collaboration with US imperialist expansion. US imperialism is criticized through the contrast between war atrocities, unscrupulous policies of

${ }^{46}$ Mellen, The Waves at Genji's Door, 236. 
intervention that change according to the shifting interests in Asia and the official discourse of US as a marker of democracy and freedom.

If the cinematic ironies highlight the gap between newsreel as national discourse and Akaza's embodied experiences, metaphors and freeze frames bring them together. Akaza's survival strategies and her lack of moral principles are used to parallel the Japanese nation that adopts the same strategies. I will highlight here the contrasting reading of this metaphor by David Desser and Joane Mellen. For Desser the metaphor of Akaza as nation is a critique of loss of values. "Her reliance on American soldiers loss of moral values just as Japan's reliance on U.S. is a loss of something deep within the Japanese spirit. " ${ }^{47}$ For Mellen the film is a celebration of Akaza's resilience and vitality that "correspond to the enormous outpouring of protest in the mass demonstrations occurring from 1945 to $1970 . "{ }^{48}$ My reading does justice to both scholars because survival and resilience mean finding agency through a relentless adaptation to changing circumstances beyond one's control. Loss of principles and survival through subjection and consumerism bring the nation and Akaza together in a metaphor that haunts many postwar films. In the post defeat years Japan as a nation experiences for the first time the embodied female condition marked through lack of control. Standish observes that Imamura focuses on prostitutes in order to critique "the economic recovery based on Japan's seemingly subservient role as provider of logistics support to American military campaigns in Asia." ${ }^{49}$ Newsreel of red purges and the crackdown on communist factions in Japan are edited together with U.S. bombing in Korea and with Akaza's experiences suggesting that the enormous political unrest in Japan is the result of transnational politics of military

\footnotetext{
${ }^{47}$ Desser, Eros + Massacre, 126.

${ }^{48}$ Mellen, The Waves at Genji's Door, 236.

${ }^{49}$ Standish, Politics, Porn and Protest, 129.
} 
strategy. The parallel between the nation and the female body is interesting for Imamura and for the New Wave filmmakers, who pursue the politicized relationship between bodies and a nation marked by unequal transnational relations. Akaza regards the American soldiers as a source of freedom from all the oppressive elements in the Japanese society: racism, abusive husbands, poverty. She hopes to escape oppression she experiences within her own country through the liberation promised by American soldiers. The ideological version of Occupation promised liberation and democracy to Japanese people, while turning Japan into an ally into imperialist war in Asia. This was a bitter realization of the 1960 s and a tremendous source of social unrest. After the militaristic period Japanese citizens realized they were being again used for imperialist purposes, a second crisis of truth that crushes hopes for democratic freedom. At the level of transnational relationship, the structure of power and domination between Japan and U.S. is consolidated through the Treaty of Mutual Cooperation, but Akaza's bodily experience shows the possibility of her own liberation.

The freeze frames used three times in the film highlight Akaza's role as witness of events. The camera freezes on a bystander of a train wreck or a demonstrator and then zooms in on Akaza's face visually linking her presence to the making of Japan's history. What is important for this visual compression of time and space is the suggestion that Akaza does not participate in historical changes but is nevertheless a witness that can interpret events from her own perspective.

The ironic contrast between images of newsreel and Akaza's voice testifying her experiences performs a double critique-of national homogenizing history and its authority to express truth as well as of the woman's limited experience unaware of the extent of the personal's involvement in the political. Freeze frames and metaphoric 
suggestions bring together the female body and the body of the nation under the sign of American domination manifested through military strategies and the embodied presence of GIs on Japanese soil. In the following part I will analyze the racial and sexual politics that place Akaza as a destroyer of the national boundaries.

\section{Madame Onboro's Body: Performing Sexual and Racial Politics}

Madame Onboro's resilience is the result of her ability to use her sexual body to enter the world of pleasure and consumption offered by the GIs. Her body stands at the borderline between prostitution and female sexual freedom. Douglas Slaymaker observes how in the post defeat context, "sex workers (especially pan-pan) obtained singular representational power as a locus of possibility and autonomy in the despair that characterized postwar society. They marked a site for protest against the preceding militaristic era." these women as a site of freedom and excess. Not only writers but filmmakers too were fascinated by these women's bodies, most famously Mizoguchi and Imamura. However, in contrast to the artistic fascination, national discourses projected these women as a threat to national respectability and to the pure Japanese body further marginalizing and stigmatizing them. ${ }^{51}$ Similar to the case of karayuki sans, the bodies of women involved with American soldiers were the objects of conflicting discourses varying with transnational politics. We must note here that the artists see the prostitute's body as a marker of sexual freedom, whereas they are a threat and a source of shame for official discourses. Akaza's body is excessive both in her sexuality and in her agency. Her body shown in medium close-up with a slightly erotic cleavage is beaming with energy while her voice is tirelessly recounting personal experiences in very vivid details, unlike the karayuki san's older body and

\footnotetext{
${ }^{50}$ Slaymaker, The Body in Postwar Japanese Fiction, 40.

${ }^{51}$ Mire Koikari, "Rethinking Gender and Power in the US Occupation of Japan, 1945-1952" in Gender \& History, Volume 1I, Issue 2, (July 1999): 313-335, 328.
} 
quiet spirit. Her sexual body is not completely objectified since she has the agency of securing lovers among the GIs and her favors are not paid directly in money. She is a hostess, not a prostitute, an essential difference between the exploitation of pan-pan workers and her sexual agency. She embodies the ambiguous border between prostitution and free love. After her experiences with two abusive Japanese partners Akaza has a series of American lovers. She marries one of them, Harry, considerably younger than her and travels to America with him planning to open a bar there in case he would desert her.

What is the relationship between sexual politics and the American Occupation of Japan? While the Occupation was hailed for the introduction of women in the public sphere through the new constitution, Occupation policies were complicated by conflicting sexual policies. Mire Koikari has shown in her interesting article that the liberation of women from 'Oriental male chauvinism' has been a central project in Japan's "reorientation." order to claim superiority over the repressive sexual politics in Japan. However, The American presence on Japanese soil entailed new sexual politics that did not empower women of low class, many of whom were forced into prostitution. Class is an important dimension that shows a particular structuring of sexual politics, with low class women deprived of self-determination. While the pan-pans were vulnerable both to sexual violence and legal violence, hostesses managed to have a certain degree of agency by choosing whom they bedded. The film shows newsreels representing the prohibition of prostitution and the rounding up of streetwalkers together with the comments of women themselves. As many scholars have shown the sexual politics of the Occupation were just as contradictory as the strategies of alliance with Japan.

\footnotetext{
${ }^{52}$ Koikari, "Rethinking Gender and Power," 313.
} 
"The meaning assigned to Japanese women's bodies was fundamentally linked to the sexual, racial, class and ultimately nationalistic politics developing between the two countries" 53 The Japanese government protected middle class respectable women by creating a buffering zone of marginal, poor, low class women to serve American soldiers. However, after only one year, in 1946, the RAA (Recreation and Amusement Association) was closed in reality because of the rapid spread of venereal disease and in the official discourse because of the Western concern for gender inequality. ${ }^{54}$ Thousands of women were thrown in the streets and became criminalized streetwalkers that were rounded up indiscriminately for medical checkups. The film shows a few newsreel scenes of these events. Akaza owns a bar while her mother bought a hotel and the film suggests that both of them were involved in the management of other women's bodies. Her economic position entails a form of agency allows her to be a step above pan-pans and relate to GIs on a different level. She has fairly long term relationships with five soldiers with whom she is also emotionally involved, including Harry, with whom she will marry and travel to San Diego. She even claims with pride that she has never had sex for money. Slaymaker suggests that, "the pan-pan was a paradoxical figure symbolizing both a desperate marginalized existence and unrestrained liberation at those peripheries." 55 Akaza's body is marked less by oppression and more by liberation, due to her problematic agency. She is a performer of sexuality, being neither a victim of transnational politics, nor a free agent and she is aware of the power of her female body to survive through changing circumstances.

\footnotetext{
${ }^{53}$ Koikari, "Rethinking Gender and Power," 326.

${ }^{54}$ For more information see Fujime Yuki, "Japanese Feminism and Commercialized Sex," In Social Science Japan Journal, Vol. 9, No. 1, (2006): 33-50.

${ }_{55}^{5}$ Slaymaker, The Body in Postwar Japanese Fiction, 35.
} 
The film does not stop at the praise of her agency in a feminist dichotomy between objectification and subjective agency. It shows how agency was possible for Akaza in the postwar years. Her family benefited from the meat trade in the black market, which allowed them to rise above the poverty level and it allowed her to buy a club. She manifests her agency by using other women's bodies for prostitution, like Tome in Insect Woman. The first shots of the film use Eisensteinian montage of the slaughtering of cows edited together with shots of the horrors in the Vietnam war. Standish argues that it creates the link between butchering and war. ${ }^{56}$ It also shows the link between violence and power through the management of death and of bodies. The slaughtering of cows show how Akaza's family rose above the poverty of their class during the Occupation using the meat of the animals in the black market. The atrocities in Vietnam are the marker of US imperialism causing death in order to achieve political and economic power.

Akaza is aware of the potential of her sexual female body to secure a place for herself in the context of Occupation. She benefits doubly from this context. The successful meat trade in the black market allowed her to rise above the poverty level while American GIs enable her to rise above the discrimination of her burakumin caste. Although the Occupation was a source of national humiliation and American military strategies in Asia subjected Japan to unwanted policies, she was able to perform successfully the sexual politics of interracial relationships. Whereas pan-pan women bore the brunt of abjection both on American and on Japanese side, her sexuality is not only a source of money but also of status change. Yokosuka is a place with an important military base and as the madam of a bar she manages other women's bodies having the agency to live her body as a subject of relationships.

\footnotetext{
${ }^{56}$ Standish, Politics, Porn and Protest, 117.
} 


\section{Conclusion}

What are the implications of the embodied history presented in these films? Both women's lives were deeply implicated in Japan's transnational relations, in Zendō's case Japan's economic and political expansion in Asia and in Akaza's case Japan's Occupation and submission to U.S. imperial expansion. The configuration of their sexuality (and consequently of their entire lives) was the result of these historical events. Their marginal position at the boundaries of the nation as second-class citizens led in the former case to Zendō's abjection beyond the boundaries of the nation and to Akaza's sense of freedom through the breach of national boundaries. Despite their lack of interest in politics and their marginal place in society, national and transnational history structures the supposedly private domain of their sexuality. Both women aimed for liberation from poverty, racial discrimination and abuse in the Japanese society. While Zendō encountered an even more radical form of abuse as a sexual object of exchange in a transnational circuit, Akaza managed to secure for herself an escape through marriage with a GI and her subsequent move to U.S. ${ }^{57}$ Their sexual bodies can be both a means of oppression and one of liberation for women. The problem is that their sexuality is a central mark of their social position, placing them within heteropatriarchal norms that structure their lives.

The films entail a radical critique of the nation but even more so, of the power of transnational politics to affect human lives. Despite his critique, we can sense Imamura's image of a unified nation that he chastises for abandoning people like karayuki sans. In The History of Postwar Japan, the nation is in a profound schism as a result of US. Imperial policies and just like during the wartime, it is a nation that

\footnotetext{
${ }^{57}$ It is arguable whether this can be qualified as a manifestation of freedom, especially since we do not know about her life in America.
} 
betrays its citizens. Besides the critique of the nation and of imperial politics the films entail a reflection on the role of cinema in the production of knowledge and the representation of history. Robert Stam and Ella Shohat formulated a film theory that pays attention not only to the visual element of the image but also to the orchestration of discourses structuring a film. "Formulating the issue as one of voices and discourses helps us to get past the "lure" of the visual, to look beyond the epidermic surface of a text. $" 58$ The metaphor of skin is not incidental since human bodies too are orchestrations of energies and intensities that are not visually available. The bodies of the two women are disciplined into serving as sexual objects although Akaza finds a way to manage her sexuality without the exclusion of her subjective involvement. The presence of conflicting views, the contrast between image and voice, between events and women's memories, nation and female bodies produces in the two documentaries a critique of truth as perspectival and contingent and a representation of female embodied history close to the feminist construction of women's oral histories.

${ }^{58}$ Stam and Shohat, Unthinking Eurocentrism, 150. 
Chapter Four. Bodies in Time: The Politics of Love, Sex and Freedom in Yoshida

Kiju's Eros + Massacre (Erosu +gyakusatsu, 1969)

I want there to be a place in the world where people can engage in one another's differences in a way that is redemptive, full of hope and possibility. Not this "in order to love you, I must make you into something else."

Unlike Imamura and Hani who used cinema to capture the complexity of reality for marginal or working class people, Yoshida tried to articulate a new cinematic language that represented the existential problems of Japanese intellectuals. Although Imamura and Hani were aware of the role played by the subjectivity of the filmmaker in the process of filmmaking they aimed to capture reality as objectively as they could. Their style and ethical stance problematized the relationship between reality and the cinematic apparatus. Yoshida on the other hand, foregrounds subjectivity highlighting the "consciousness of objects." His films portray events from the standpoint of one or more characters focusing on the filtering processes of subjectivity.

He makes explicit this existentialist position in his famous theory of selfnegation (jiko hitei), which I will explore in the first part of this chapter. In this theory he emphasized the presence of individual subjectivity as an open, transformative engagement with the world both in his filmmaking practice and in the content of his films. While their approaches to cinema and their techniques are radically different, the three directors share common preoccupations and views. First, they are interested in the relationship between sexuality and politics. In his most famous film, Erosu + gyakusatsu (Eros + Massacre, 1969) Yoshida explores the configuration of love and sexuality in the 1960s by returning to Ōsugi Sakae and Itō Noe, two historical figures

\footnotetext{
'bell hooks, Reel to Real (New York: Routledge, 1996), 153.

${ }^{2}$ Standish, Politics, Porn and Protest, 112.
} 
in the 1920s, anarchists and advocates of free love. The second aspect that connects these three filmmakers is their approach to the representation of women and their articulation of female voices, gazes and perspectives on love and sexuality. Instead of making spectators gaze at female bodies, they want to make them look at what it means to be a woman in postwar Japan. Third, their films are self-reflexive about the process of cinematic representation. Among these filmmakers Yoshida has been the most articulate in terms of self-reflexivity. He is also a prolific author and has published many studies that speak about his approach to cinema, the role of the director and his relationship with the filmed object.

If Imamura used cinema as an anthropological extension, Yoshida expressed a phenomenological stance that relentlessly explored the relationship between director, cinematic world and spectator. Saltō Ayako regards Yoshida as one of the most "auteur-like" film director in Japanese cinema because of his focus on subjectivity, his independence from the studio system and his theories of film. ${ }^{3}$ Although he started working at Shochiku directing melodramas, he later broke away from the studio, making independent films and in the late 1960s he collaborated with Art Theatre Guild continuing to make films to the present. In this chapter I will analyze the political dimension of male and female bodies, focusing on the impact of historical transformation on the configuration of love and sexuality in the film Eros + Massacre. Time and history are foregrounded both in the narrative structure and the visual aesthetic of the film, which brings together the 1920s with the 1960s. The film's construction of time is crucial for understanding the relationship between bodies and history. The sexual freedom enjoyed by the characters in the $1960 \mathrm{~s}$ is

\footnotetext{
${ }^{3}$ Saito Ayako, "Josei to mōsō-Yoshida Kiju to Okada Mariko," [Women and Fantasy-Yoshida Kiju and Okada Mariko], In Yoshida kiju no zentaizō.[The Collection of Yoshida Kiju's Films], ed. Yomota Inuhiko (Tokyo: Sakuhinsha 2004), 70.
} 
haunted by alienation due to the lack of emotional, subjective involvement that can be retrieved by returning to the past. The second aspect I will analyze is the film's representation of the female body both as subject and as object of desire, where sexual love is portrayed as mutual negotiation between male and female subjects that questions gender hierarchies. I will also analyze Yoshida's feminist strategies of ethical negotiation between his position as a male director and Okada Mariko as actress.

Eros + Massacre was produced in collaboration with Art Theatre Guild, whose purpose was to bring Japanese tastes in line with international trends and to support independent filmmakers. The film foregrounds in its very structure the political dimension of bodies and heterosexual love by comparing and contrasting two historical periods: Japan in the $1960 \mathrm{~s}$ and in the $1920 \mathrm{~s}$. The film rejects the Hollywood style narrative and it is structured around what Yomota Inuhiko calls cinematic "cells" that connect the two time periods and relate various characters around the issues of love, freedom and sex. ${ }^{4}$ In the 1960 s the film portrays two fictional characters, Eiko (Ineno Kazuko) and Wada (Harada Daijirō), student radicals involved in a complicated sexual relationship haunted by Eiko's prostitution. ${ }^{5}$ The 1910-1920 period represents the historical figure of Ōsugi Sakae (Hosokawa Toshiyuki) and his advocacy of free love reflected in his involvement with three women: Hori Yasuko (Yagi Masako), his wife, Kamichika Ichiko (Kusunoki Yūko) and Itō Noe (Okada Mariko), an important feminist figure active in the feminist

\footnotetext{
"Yomota Inuhiko, "The Genealogy of the Mother," In Yoshida Kiju-50 Years of Avant-garde Filmmaking, ed. Dick Stegewerns (Oslo: Norwegian Film Institute, 2010), 43.

${ }^{5}$ The film only gives the first names of the characters and this is how I will subsequently refer to them, although I refer to the other characters by their family name.
} 
literary magazine Seitō (Bluestockings). ${ }^{6}$ The film introduces a plurality of perspectives on the issues of bodies, love, sexuality and freedom, more clearly delineated through the differences between the two historical periods. Historical time marks differences between bodies and definitions of love and sexuality.

I will start my analysis of the film with the consideration of Yoshida's approach to filmmaking as an ethical negotiation between self and Other exemplified by his relationship with the actress Okada Mariko. This negotiation is not only a filmmaking technique but also it lies at the core of the film that shows the entangled engagement of embodied subjects through love and sex. He tries to maintain a balance between his power position as a male director and the female actress, an ethical stance also visible in his style that shows both male and female perspectives on love and sexuality. The next part of my analysis of the film will be concerned with the historical configuration of love, sexuality and freedom divided along gender lines in the 1960s and 1920s. In the third part I will analyze the meaning of the mediation between past and present outlining the affective legacy sought by women as a continuous search for equality in love and sexual relationships.

\section{Mutually Interacting Subject Bodies: The Director and the Actress}

Much has been made by Yoshida's theory of self-negation (jiko hitei), the negation of the subjectivity of the filmmaker, a paradox when considering his strong position as an auteur. His views on the process of filmmaking are remarkably close to what Vivian Sobchack has suggested in terms of theorizing films. ${ }^{7}$ Instead of seeing film as an object, they both see it as a subject that engages both the director and the

\footnotetext{
${ }^{6}$ Kamichika Ichiko is the real name of one of Ösugi's lovers, a journalist who had become a member of the diet when the film was made and who laid charges against the film on grounds of defamation. As a result, Yoshida changed her real name to Masaoka Itsuko in the film.

${ }^{7}$ See Vivian Sobchack. The Address of the Eye: A Phenomenology of Film Experience (New Jersey: Princeton University Press, 1991).
} 
spectator in a transformative encounter. Previous generations of filmmakers used conventions to convey a previously constructed idea to passive spectators. However, for Yoshida, the film is a personal engagement of the director with others and with his/her own contemporary world. It is fundamentally an act of transcendence. "Making a film is an act that transcends me, that pushes me forward, closer to the unknown." ${ }^{\prime 8}$ Contrary to a formed subjectivity of the filmmaker communicating an idea that the audience is supposed to absorb passively, for Yoshida film is an act of intercommunication and negotiation among opened subjectivities. "I believe it is necessary for the filmmaker and the critic to free themselves from the walls of the subject (shukan) and build a subjective (shutaiteki) space.",9

Eros + Massacre bears a double political significance for Yoshida. First, in terms of the film's content he aims to show "the buried energy of Japan's younger generation," focusing on the political dimension of love and sexuality. ${ }^{10}$ Second, Yoshida is explicit about the political role of filmmaking in the encounters and negotiation it produces between director, the filmed objects/subjects and spectators. As Patrick Noonan suggested, political filmmaking is both a matter of the political content of the films, and the form and reactions they produce. "Political filmmaking does not only mean criticism of ideology but engaging filmmakers and audiences as critically engaged subjects." "While Imamura distances spectators through irony and his scientific approach, Yoshida abandons narrative conventions and the emotional

\footnotetext{
${ }^{8}$ Yoshida, Kiju. "My Film Theory-The Logic of Self-Negation," In Yoshida Kiju-50 Years of Avantgarde Filmmaking, ed. Dick Stegewerns (Oslo: Norwegian Film Institute, 2010), 105.

${ }^{9}$ Yoshida, "Hihyō wa motto kakkoku no mono de aru," [Criticism Can Be More Diversified] in Jiko hitei no ronri-sozoryoku ni yoru henshin [The Theory of Self-Negation-Transformation Through Imagination] (Tokyo: Sannichi Shobō, 1970).

${ }^{10}$ Yoshida, "Kamera wa seiji ni nikuhaku dekiru ka," [Can the Camera Challenge Politics?)] In Shinario 16.8 (August 1960): 66-67.

${ }^{11}$ See Patrick Noonan, "The Alterity of Cinema: Subjectivity, Self-Negation and Self-Realization in Yoshida Kiju's Film Criticism," In Decentering Theory: Reconsidering the History of Japanese Film Theory, Review of Japanese Culture and Society (Tokyo: Josai University Press, 2010), 110-129.
} 
exchange created between the director's vision and spectators using film as a negotiation, as a dialogue involving multiple subjectivities that cluster around existential problems such as freedom, love, choice, death. He is aware of the gender hierarchies (male directors as subjects/female actresses as objects) involved in the filmmaking process but nevertheless he believes in cinema "as social process, as encounter that articulates selves and others' ethics of the cinema relationship in which neither party is assimilated into a singular totality." 12 The internal world of the filmmakers is related to the external world of things and in that sense the subject is continuously redefined through interaction with others. ${ }^{13}$ Yoshida's approach to filmmaking creates a relationship that questions gender hierarchy between filmmakers as the manipulators of the technical apparatus and actresses as performing bodies, as objects of vision. He defies the gender hierarchy in the institution of filmmaking, framing it as equal negotiation between discrete subjectivities. The content of his films also shows this mutual engagement of subjectivities in the act of sexual love. As I have argued in the chapter on Imamura's documentaries, the ethical position of the filmmaker entails a negotiation of his power as a creator of meaning about the Other, which is also characteristic of Yoshida's approach to cinema.

In his analysis of Yoshida's theory of self-negation Noonan argues that the actress Okada Mariko “articulates through her own language, gaze and gesture the filmmaker's subjectivity." "While this idea may hold true for most collaborations between directors and actresses, it is important to note that Okada's powerful presence is also a marker of her own subjectivity, rather than a mere vessel, a body that performs the director's vision. Okada Mariko is an actress famous for her beauty and

\footnotetext{
${ }^{12}$ Noonan, "The Alterity of Cinema," 112.

${ }^{13}$ Ibid., 117

${ }^{14}$ Ibid., 112.
} 
her strong personality. She starred in more than 150 films and she wrote a book about her career as an actress. As an actress, producer and Yoshida's spouse, she was also a partner in his career. Saltō Ayako argues that, "in Yoshida's films Okada is most of all present by her looks." 15 In other words, she has her own presence that is not reduced to the image the director wants to create through her casting. Saito argues convincingly that the particularity of women portrayed by Yoshida is that they are not subjective "absences" brought to life by the director's vision. On the contrary, "women may have the possibility to be freed from essentialism. They stand at the opposite end of the "essence" and 'maternity' as defined by the rules of patriarchy." "16 What Saitō defines here is an idea close to my approach to the three filmmakers I analyze in this dissertation. They all open up the space for the expression of women's subjectivity and sexuality without estranging them as "the homeland of men."17

In her memoir, Okada asked Yoshida what he thought of her as an actress, to which he responded: "You are an actress with very strong personal presence, ( $k i$ no tsuyoi joyuu) a rarity in Japanese cinema." 18 Okada plays a particular role in Yoshida's film as an intense presence communicated especially through the relentless gaze of her big eyes. Yoshida himself took pride in the scarcity of directions he gave to the actor and the lack of a pre-established role. "As a director, nothing makes me happier than when the actor's presence, right there, expresses an incisive critique... The actor does not express something through his/her body but the body is expression itself."19

In Eros + Massacre Yoshida tried to represent the charm of the living body of

\footnotetext{
${ }^{15}$ Saito, "Josei to mōsō," 84.

${ }^{16}$ lbid., 83 .

${ }^{17}$ Ibid.,

${ }^{18}$ Okada Mariko, Joyũ Okada Mariko [The Actress Okada Mariko] (Tokyo: Bunshun, 2012), 244.

${ }^{19}$ Yoshida, "My Film Theory-The Logic of Self-Negation," 106.
} 
actors, their bodily presence, even more than the types of characters they were supposed to play. ${ }^{20}$ This approach to filmmaking dismantles the scopic regime of cinema that turns women into performing objects dutifully reflecting the director's vision. In its place we have a continuous negotiation where Okada articulates Yoshida's subjectivity and her own presence while Yoshida is himself changing his subjective position under Okada's presence. His view of cinema as negotiation between filmmaker, actors/actresses and spectators extends to his views on gendered relationships. I agree here with Saitō's insight that although many avant-garde filmmakers challenged commercial filmmaking, they did not acknowledge their male privilege. On the contrary, "Yoshida looked upon his masculinity with skepticism and it seems as if, by borrowing Okada's look, he aimed to implement the narration by the Other." 21 His self-reflexive attitude regarding his masculinity had important consequences for his filmmaking style. Yoshida's professional relationship with Okada as mutual interaction extends to Yoshida's ideas about filming women. Instead of filming women as Others, he represents their subjectivity as well as their long history of living under patriarchy. ${ }^{22}$ Like Imamura and Hani, Yoshida refuses the catharctic emotional exchange between spectators and filmmakers based on preset ideas or emotions the directors would want to convey. Films are as much a selfdiscovering experience for them as it might be for spectators. They also interrogate the gender hierarchy inherent in the cinematic medium offering memorable representations of women as subjects.

In an interview with Chris Fujiwara, Yoshida explains his interest in making films about women, while he dissociates himself from the essentialization and

\footnotetext{
${ }^{20}$ Okada, Joyū Okada Mariko, 342.

${ }^{21}$ Saito, "Josei to mōsō," 120.

22 Okada herself stated that she acted in this film regarding it as a film about women who try to break away from the tyranny of patriarchy, see Okada, Joyü Okada Mariko, 359.
} 
abstractization of Mizoguchi's women. "Since I'm a man, very naturally the most important subject for me to describe is women, because they are an enigma for me. So most of the time my protagonists are women. I don't really want my films to be categorized as women's films, because for me my films are about the most important enigma for me in my life, which are women. And I can stress that point not only because I'm a man and a male filmmaker but because Japan still today is predominantly a male society." 23 Yoshida is stressing here his own male position that plays an important role in the ways in which women are represented as the Other, unlike women's own representation of themselves. The enigma of women is a wellknown trope both in psychology and in art making but I am interested in the ways Yoshida articulates his desire to let women have their own voices and gazes. His films make possible a form of intersubjective negotiation that defies power, an aspect I will explore more closely through the analysis of the film.

Through his phenomenological view of filmmaking as a transformative engagement of the self with the Other, Yoshida negotiates his power position as a male filmmaker. He creates an ethical discourse of self-negation allowing the actress Okada to act out her own subjectivity rather than enacting a certain type of woman corresponding to his vision. We can consider his idea of filming women as a feminist strategy of open subjectivity engaging the world in a mutually transformative way. Eros + Massacre is a film that puts into practice these ideas since it represents the politics of love and sex by contrasting and bringing together the free sex in the 1960 s' consumerism and the free love in the 1920s. Moreover, it shows both women's and men's bodies and subjectivities portraying free love as an ideal form of equal gender engagement constantly unraveled by power structures. I will analyze in the following

${ }^{23}$ Chris Fujiwara, "Interview with Yoshida Kiju," In Yoshida Kiju-50 Years of Avant-Garde Filmmaking, ed. Dick Stegewerns (Oslo: Norwegian Film Institute, 2010), 8-14, 11. 
part the consumerism and individual alienation experienced by the youth of the $1960 \mathrm{~s}$, whose pursuit of free sex precluded the emotional counterpart of love. A young woman's alienation and lack of affective intensity leads her to search for the meaning of love in the revolutionary Taisho era. She becomes the link between the past and the present through her imagination and her desire to connect to a female legacy. I will analyze the visual representation of the two time periods separately in order to highlight the differences between the historical representation of love and sex.

\section{The 1960s Free Sex and the Body as Object of Desire}

The film brings two time periods into dialogue through subjective mediation, creating what Gilles Deleuze has called "time-image." 24 While Deleuze referred to the postwar cinema in Europe as the marker of a rupture in the causality of time, it is a valid concept to explore Yoshida's films in the 1960s that were preoccupied with the subjective duration of time and the impact of history on the consciousness of characters. Deleuze's observations on the new type of filmmaking in the postwar years are quite similar to the epistemological crisis noted by many theorists in postwar Japan. $^{25}$ The postwar circumstances "greatly increased the circumstances [to] which we no longer know how to react $\{\ldots\}$ in spaces which we no longer now how to describe." 26 This epistemological rupture has been pointed out by many scholars on Japan as a transformation of ideology, subjectivity and gender relationships. Ōshima Nagisa pointed out this rupture in the domain of sexuality "With the loss of the war, when the power of all mysterious things come crashing down to earth, sex was one of

\footnotetext{
${ }^{24}$ See Gilles Deleuze, Cinema 2-The Time Image, tr. by Hugh Tomlison and Robert Galetta (Continuum International Publishing Group, 2005).

${ }^{25}$ See Yoshikuni Igarashi, Bodies of Memory: Narratives of War in Postwar Japanese Culture (New Jersey: Princeton, University Press, 2000), Douglas Slaymaker, The Body in Postwar Japanese Fiction (London and New York: Routledge Curzon, 2004) and Mark MacLelland, Love, Sex and Democracy in Japan during the American Occupation (New York: Palgrave Macmillan, 2012).

${ }^{26}$ Deleuze, Cinema 2-The Time Image, $\mathrm{xi}$.
} 
them..."27 Deleuze's insight is useful to explore how the historical upheaval entailed by WWII changed modes of representation, whereby cinema starts using what he calls "characters in the grip of mutation." ${ }^{, 28}$ Cinematic representation engages with new kinds of subjectivities that lost their stability in time and space. This is valid for Yoshida's films that construct an unstable and interpersonal notion of subjectivity and the body. While Deleuze's dichotomy between action image as pertaining to prewar cinema and time image as representative of postwar cinema is questionable, I would like to point out that Eros + Massacre performs the kind of representation pointed out by Deleuze in his theory of the time image. "The screen itself is the cerebral membrane where immediate and direct confrontations take place between the past and the future, the inside and the outside, at a distance impossible to determine, independent of any fixed point. The image no longer has space and movement as its primary characteristics but topology and time." ${ }^{29}$ Eros + Massacre does not progress through action but instead lets the past infuse the present with meaning and value through time images. There are affective flows both in interpersonal relationships and between time periods. If for Keiko MacDonald, the time of the characters in the $1960 \mathrm{~s}$ is "an expanse of vacuum," I argue that it is precisely that vacuum that absorbs the past in order to confer meaning to sexual relationships. ${ }^{30}$ Time operates not so much as memory (since the experiences of Ōsugi and Itō are not the experiences of the young characters in the 1960s) but as a subjective intellectual and imaginative process of selection and transformation performed by Eiko, the main character in the film.

Eiko is both the subject of the story and the subject of the sexual/love

\footnotetext{
${ }^{27}$ Ōshima Nagisa, Cinema, Censorship and the State, 1956-1978. tr. by Dawn Lawson (Cambridge: MIT Press, 1992), 245.

${ }^{28}$ Deleuze, Cinema 2-The Time Image, 19.

${ }^{29}$ Ibid., 121 .

${ }^{30}$ Keiko MacDonald, Cinema East; A Critical Study of Major Japanese Films (London and Toronto: Associated University Presses, 1983), 176.
} 
relationship with Wada but at the same time, she is also an object of desire as a prostitute. Through the representation of her body as object of desire the film selfreflexively portrays the visual commodification of the female body on the rise in the postwar period. However, unlike Imamura's heroines that are forced by oppressive circumstances to become sexual objects, Eiko is freely choosing to offer her body for money. Despite her freedom, she feels a profound alienation and lack of emotional fulfillment in sexual relationships. This sense of dissatisfaction leads her to search for meaning in the past. As Yomota Inuhiko has suggested, Eiko attempts to create her own story. "She distances herself from the manipulations of the story by the authorities and longs to become a subject that more actively manipulates the story."31 She pursues her own desires and develops a love relationship with Wada, who is unable to have sex with her due to his traumatic past. Desser too suggests that Eiko becomes the main protagonist of the film and thus the subject of the story. "It is Eiko who possesses desire, desire for sex, desire for politics, desire for cinema. It is her desire, her will, which eventually makes her the main protagonist of the film, just as her desire and will make Itō Noe, the central protagonist in the complex interactions of the members of the Ōsugi's radical circle in the Taisho era." ${ }^{32}$ Both Itō and Eiko pursue feminist strategies of self-realization, aiming to come to terms with their emotions. Eiko pursues her desire to come to terms with emotions surrounding sexuality by returning in time to the revolutionary feminist period of 1910-1920s and her subjectivity guides the construction of the film that creates continuity between past and present. In contrast with her, the two men she is involved with, Wada and Unema, both reject the past but this gesture deprives them of their emotional life.

\footnotetext{
${ }^{31}$ Yomota," The Genealogy of the Mother," 47.

32 Desser, Eros + Massacre, 202-203.
} 
The 1960 s sexual revolution in Japan appeared to the youth of the 1960 s as an unprecedented freedom to choose one's partners both for men and for women. Mark McLelland notes that sexual liberation in Japan had a different meaning than the sexual revolution in the Western world since male sexuality had not been confined to marital relationships. The emphasis on sexual love as mutual sexual fulfillment opposed to procreation seemed liberating. For many people, "free love meant the freedom to choose their own marriage partner without parental or societal influence." ${ }^{33}$ The discourse of bodily sensual liberation (of male bodies) started with the end of WWII but in the 60s, bodily liberation was associated with the idea of free love and sex, a discourse also claimed by women. While the discourse of sensual pleasure as liberation from social constraints was very much a male discourse and it was predicated on the transformation of women into sexual objects, the film also focuses on what the liberation of the body meant for women and the difficulties they encountered in the search for equality in sexual love.

The first scene describing the 1960s shows Eiko's prostitution, more precisely the phenomenon of enjo kosai that would become a national outcry in the $80 \mathrm{~s} .{ }^{34} \mathrm{Her}$ body is shot fully naked in various visual compositions that stress it as an object to be consumed, both in reality (the real of the film's narrative) and in the image. The scene shows carefully framed shots of her sexual encounter with a man who pays her and who is also a TV director, a self-reflexive reference to the cinematic reproduction of desire for the female body. Eiko's naked body is shot from the perspective of the male gaze that aligns spectators with the man's desire. The camera pans over her body caressed by Unema, performing a triple alignment of the male character, camera and

\footnotetext{
${ }^{33}$ McLelland, Love, Sex and Democracy in Japan, 74-75.

${ }^{34}$ The term roughly translates as "aid date," implying usually a young girl receiving money for sating and sleeping with older men. See Sonya Ryang, Love in Modern Japan, Its Estrangement from Self, Sex and Society (New York: Routledge, 2006).
} 
spectator's gaze in the representation of desire the female body. Eiko's body becomes erotic both for Unema and for the camera but while the film restitutes her subjectivity, the economic exchange between her and Unema prevents it. Laura Marks defines eroticism as "the ability to move between near and far, between control and relinquishing, being giver and receiver." 35 The erotic encounter takes the beloved "to the point where there is no distance from the body." 36 Prostitution prevents eroticism for women since it is predicated on an unequal exchange. This exchange freezes the erotic movement between subject and object, turning the woman into an erotic object, which precludes her active engagement. Her body caressed by Unema is animated by bodily pleasure but her pleasure is alienated from her own desires.

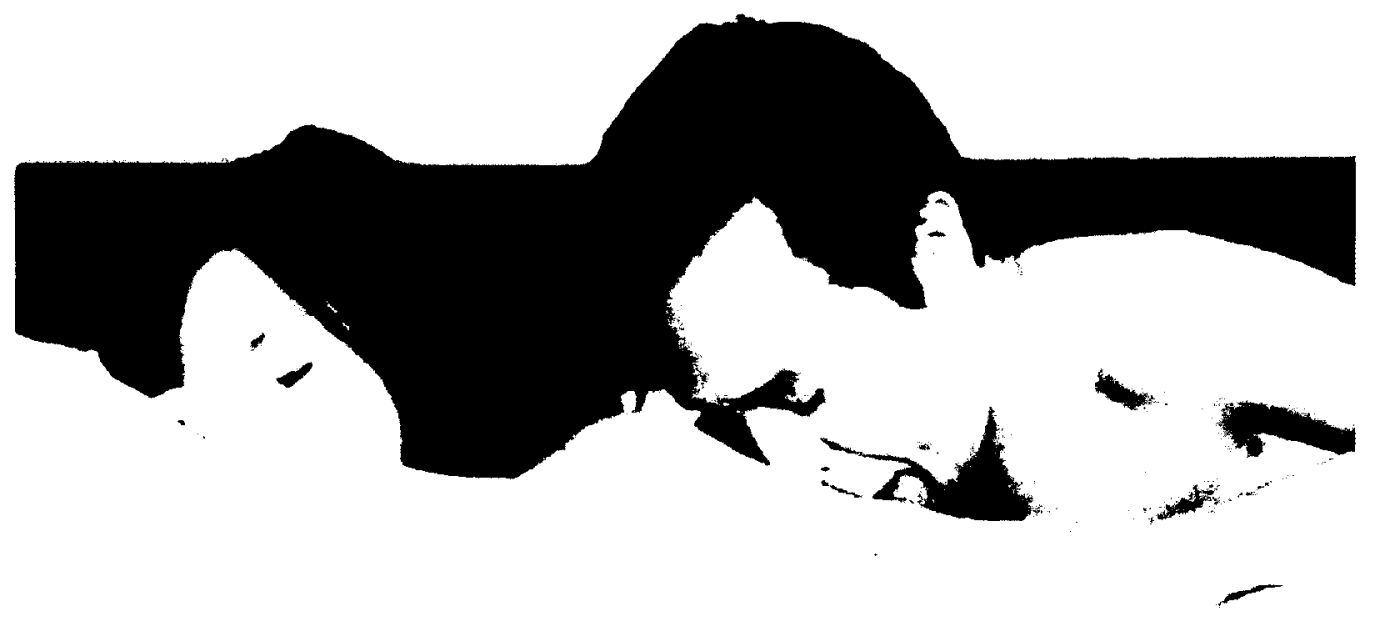

Eiko's body becomes an object of desire both for the man and for the camera.

A later scene describes Unema's objectification of the bodies of women he uses as models. As two women dance in front of the camera, (visible in the frame), his voice admonishes: "You cannot laugh. You are not human beings, you are beautiful models." ${ }^{37} \mathrm{He}$ possesses the power over the image and also the power to appropriate the female body for his own desires but he will finally fail and commit suicide with

\footnotetext{
${ }^{35}$ Laura Marks, Touch (Minneapolis/London: University of Minnesota Press, 2002), xvi.

${ }^{36}$ Ibid.

${ }^{37}$ Eros + Massacre.
} 
the very strip of film he used to turn reality into images of his desire. Through this character the film self-reflexively analyzes the apparatus of cinema underpinned by the male gaze that turns women into sexualized bodies. The gaze is connected to anxiety and desire reducing women to the sexual visibility of their bodies. Unema is the bearer of the gaze both in his filmmaking and in his relationship with Eiko. The film portrays the male gaze as ultimately destructive and alienating.

In the other room, the young Wada, head against the wall, oversees the sexual encounter between Unema and Eiko but he is alienated from the male gaze as he loves her and sees the sexual encounter as a form of vulgar commodification of the body. When Eiko enters the shower, her body is represented teeming with a desire unfulfilled by the sexual encounter. Wada's hands meet her hands across the shower's window, a sign that he cannot touch her body since they are both alienated from their passions. Eiko's lack of fulfillment takes her back in time to the characters of Ōsugi and Ito in the $1920 \mathrm{~s}$, through a subjective flashback. She creates a unity of time as a continuity of past into the present through her dissatisfaction and search for meaning in a feminist legacy. Time images are subjective recreations of the past that serves as key for understanding the present. Besides creating time images, the film creates a multiplicity of perspectives, with each character witnessing other characters' bodies and subjectivities, a technique that presents love and desire through subjective, contesting perspectives. This perspective shows the male gaze and male desire as only one among others, avoiding its centrality and negotiating its power.

There is a multiplicity of perspectives on Eiko's sexual body: for Unema, the man who pays for it, it is an object of pleasure, for Wada who loves her it is a forbidden promise of physical and spiritual fulfillment, for the interrogator as representative of state authority, it is a crime scene and for Eiko her body is both an 
instrument she can use for money and a potential source of pleasure and freedom. She derives power and pleasure from the objectification of her body, since she can manipulate men's desires but she feels alienated from her own desires.

Yoshida, like Imamura and Hani, self-reflexively analyzed the power of the camera to restrict the richness of women's subjectivities to their sexualized image of bodies as reflections of male desire. This pessimism towards cinema has been read as elegy of the New Wave and the failure of the 1960 s revolutionary potential. ${ }^{38}$ I would add to this idea that this pessimism foresees the massive commodification of the female bodies under way in the 1960s. The cinema as a political tool for reflecting on the relationship between love, sexuality, bodies and politics will turn into an instrument of patriarchal power manifested as the commodification of desire. Just like the desire for change, freedom and democracy has been leveled up by the promises of consumerism, the desire for equality and mutuality in sexual relationships will turn into the consumerism of female bodies.

The "dilapidated era called present" is haunted by the alienation, vulgarity and bareness of consumption society, most strikingly represented by Unema. ${ }^{39}$ Eiko's sexual freedom leads to her own commodification of her body, a new form of the "technology of the self" pointed out by Foucault, where the subjects perform themselves the rules of power. As Foucault has warned, "we must not think that by saying yes to sex we say no to power. ${ }^{40}$ Her freedom means for her an alienating participation in a sexual system of exchange. She struggles to forge a relationship between love and sexuality, which she can only experience separately. Her relationship with Unema is based on sex without love while her relationship with

\footnotetext{
${ }^{38}$ Desser, Eros + Massacre, 192.

"Yomota,"Genealogy of the Mother," 47.

${ }^{40}$ Foucault, History of Sexuality, 157.
} 
Wada is framed in terms of love without sex. Her body is both an object and the locus of her own desires as she stages her sexual encounter with Wada and helps him "light up her flame."

The flame functions as a powerful symbol of passion, sexual pleasure and death, appearing in numerous instances of their encounter. Wada looks at Eiko's body through the camera but he cannot make love to her since he is haunted by a sexual trauma. He obsessively uses a lighter and talks about fire, fascinated by its destructive power but he rejects Eiko's advances as well as her desire to interrogate the past. His impotence needs the destruction of the past as a form of cure. ${ }^{41}$ In the scene of their sexual encounter Eiko challenges him and defiantly undresses in front of his camera. The wordplay between lighting one's fire and lighting a fire projects their sexual encounter against destruction. Both of them are framed half naked in a medium shot against a projection screen. Wada holds a lighter and a rope against his neck and talks about death as the ultimate pleasure. She grabs his lighter and sets fire to the things around them with the flames in the foreground lighting up their passionate embrace. Wada can access love and sex through the destruction of the past, a metaphor for free love characteristic of the 1960s. The two young students experience passionate carnal encounter only close to destruction.

\footnotetext{
${ }^{41}$ I find this idea interesting in relation to many critics' remark about the crisis of masculinity due to Japan's feminization in relation to America. The fact that Wada's sexual trauma is related to homosexual abuse, just like in Hani's film can only confirm the idea of the loss of masculinity trying to reconstruct itself through sexual relationships.
} 


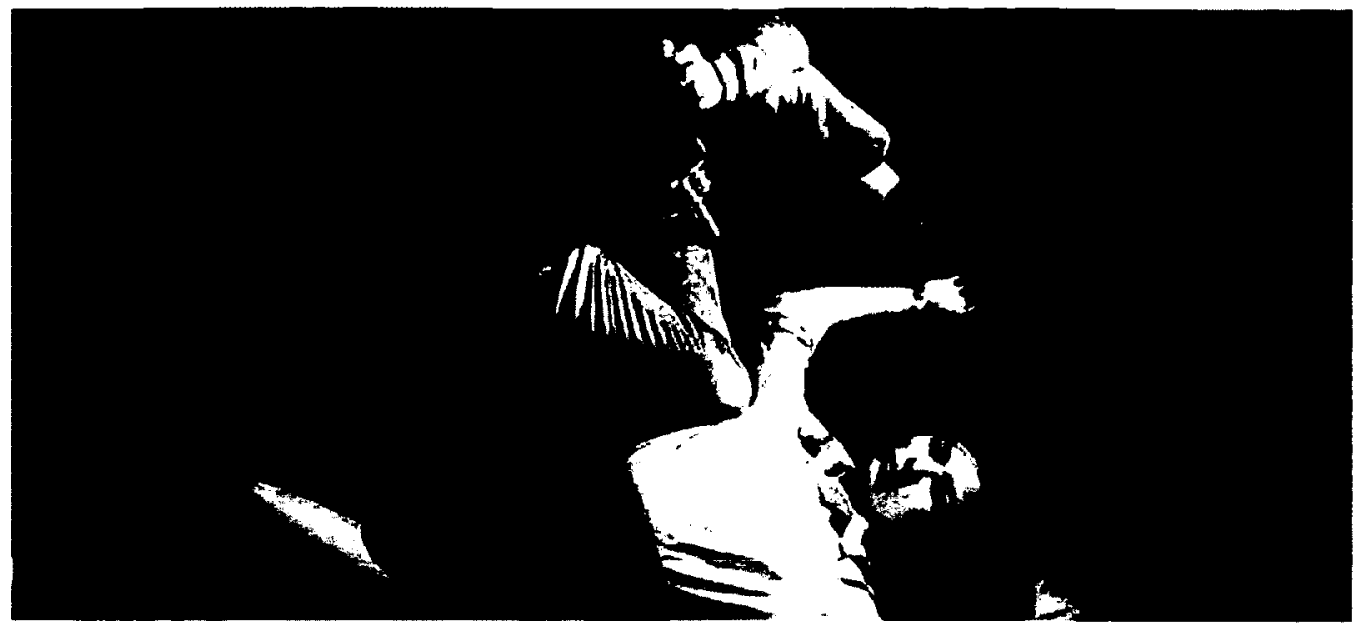

The camera is foregrounded here in a self-reflexive exploration of the cinematic role in the construction both of desire and of knowledge about the Other.

What is the relationship between love and sex and why are they separated in the 1960s? Satō reads the relationships in the 1960s as being governed by "the empty pursuit of free sex," which is "connected with the loss of ideals in the opposite sex."42 He suggests that, "for human beings the opposite sex is not a mere sensual object but many dreams and ideals crystallized in the emotion of love. ${ }^{, 43}$ In contrast to free love, free sex offers a democracy of sensuality, where the others are reduced to their sexual bodies, a materialism that searches for more and more bodily pleasure because of the lack of emotional fulfillment. I believe Satō's idea is useful for disentangling the politics of love and sex. If patriarchal norms in the prewar era allowed men to have families and enjoy bodily pleasures in the pleasure quarters, separating sex for procreation and social status with sex for pleasure, the postwar era brought these spheres together while also questioning their meaning for women. However, the liberation of sex is also an expression of the commodification of desire that McLelland noticed in the postwar years. "The freedom that the newly conspicuous dating couples wielded was the freedom to bring their relationships in line with an

\footnotetext{
${ }^{42}$ Satō, Currents in Japanese Cinema, 97.

+3 Ibid.
} 
ever expanding U.S. economy of identity, consumption and desire."44 As McLelland points out, in the postwar period women in general become objects of desire, not only those socially designated as objects of pleasure. ${ }^{45}$ At the same time, women too claim sexual relationships as sources of personal gratification and pleasure. The sexual revolution found its utmost expression in the free sex of the 1960s but Eiko wants to find love as an expression of affective and bodily source of meaning and pleasure. I will thus argue that the film critiques the alienation of bodily desire from affect.

The somewhat naive ideal that romantic love is based on mutual affection and the agency of both the man and the woman in the sex act is also a trait we find in Hani Susumu's film analyzed in the last chapter. Just like these directors negotiated their power to produce representations of women, the young men in their films negotiate their relationships with women in a context of reciprocity. How is love portrayed in the context of the 1960s as the unseen emotion related to the seen sexual encounter? Unlike the characters in the 1920 s who proclaim their ideas of free love as a political and existential tool, the pair in the 1960s search for scenarios revolving around love and death. The postponing of their sexual act leads them to the desire to find out more about the other, especially about their past. They touch and embrace in various shots with bodily gestures that show not only desire for the body but also the desire to love and to know the other. While Wada films Eiko's body he talks to her about his sexual trauma. They create scenarios that integrate their sexual desire for one another into larger discourses about death and passion. I will analyze more closely a scene that recreates such a scenario.

\footnotetext{
${ }^{44}$ McLelland, Love, Sex and Democracy in Japan, 183.

${ }^{45}$ Ibid.,
} 
Both students run through a construction site littered with unfinished walls and mud hills, a symbolic mise-en-scene for their effort to construct their love relationship among a wasteland. Eiko sits against a wall while Wada circles her reciting a scenario of desire and death. "We are going to a hotel. You don't want. Then I am stabbing you (makes a stabbing gesture and Eiko pretends she is dead). I'm embracing you. It is beautiful." They run against a mud hill and the camera shows a long shot of their bodies. He follows the line of her body against a soundtrack of excited breaths full of desire. "I enter you." "You enter me" Eiko exclaims in ecstasy. "Can you see? Wait." Wada defers the imaginary sexual act in order to include a mock interview against the image of the cross. The two young students need to go through their past in order to love but the man can only love and have sex through the destruction of the past while Eiko can love through the discovery of a continuity with the past. While sex is described as bodily desire, love is an affective negotiation between two subjectivities that need to come to terms with the past and with their differences. The past of the 1920 s and the present of the 1960s are different both in terms of narrative (free love as opposed to free sex) and in terms of their cinematic construction.

The imagery of nature, traditional Japanese houses and gardens in the 1920s are contrasted with images of ruins, film studios, bars and cramped rooms in the 1960s. The music accompanying the representation of the past is lyrical and melancholy while the soundtrack of scenes representing the 1960 s is of psychedelic rock music. The performance of the two lead female characters highlights the difference between a self-conscious, feminist Itō Noe played by Okada and the alienated Eiko. As Keiko McDonald suggested, "Noe's freedom and vitality (is) counterpoised with Eiko's sense of ennui and stultification." ${ }^{, 46}$ The images of love

\footnotetext{
46 McDonald, Cinema East, 178.
} 
relationships are also framed differently. The representation of love in the $1920 \mathrm{~s}$ is very restrained in terms of sexual imagery reminding of classical Japanese cinema (with emotions suggested by facial expressions, actions or elements of nature). In contrast, the representation of sexual relationships in the 1960 s relies extensively on graphic descriptions of sexual encounters but it lacks the emotional intensity of love both in its narrative and its visual construction.

Eiko tries to recover from the Taisho period a discourse that includes love, vitality and passion in the sexual encounter. The time image works as Eiko's intellectual and imaginative reconstruction of the past in order to understand her present. The film builds this difference between bodies reduced to an inert form of sexual materiality in the 1960 s and bodies animated by intense passions in the $1920 \mathrm{~s}$. If the apparatus of cinema is well equipped with portraying the sex of the bodies and their interaction based on sexual desire, what strategies does it use to represent love? Is sex the seen counterpart of sexual love ${ }^{47}$ In the following part I will analyze the representation of the 1920 s and its passionate love affairs reconstructed subjectively by Eiko. Like in a hall of mirrors, the characters witness each other under the constantly interrogated ideas of love and freedom. I will argue that the multiplicity of perspectives is a feminist strategy employed by Yoshida to portray love and sexuality as a constant negotiation among embodied subjectivities. Instead of the male gaze present in the $1960 \mathrm{~s}$, the characters in the Taisho era engage each other's gazes.

\section{Visual Negotiation in the 1920 s- Free Love as a Political Tool}

The first scene representing the past shows Ōsugi and Itō in high angle shots strolling under the cherry trees in blossom. The image is associated with the

\footnotetext{
${ }^{47}$ I am not including here the kiss as the seen counterpart of love because of the cultural controversies surrounding the kiss as an expression of sexual love in Japan. Hollywood romantic films represent love as a gradual buildup of emotion visually represented through kiss, sex and eventually marriage.
} 
soundtrack of a melancholy music and is edited after the scene of Eiko's alienated sexual encounter with Unema. The close-up of Eiko's face in the shower reading a passage about Itō's life is followed by the cherry blossoms scene where Itō and Ōsugi declare their love for each other. The whole sequence functions as time image brought to life by Eiko's imaginary return in time. This mode of editing establishes a contrast between loveless sex and the intensity of passion guiding the characters in the Taisho era. Tracking shots of their stroll alternate with close-ups of their facial expressions. The cherry blossoms are memory markers as the characters travel back in time to another scene of cherry blossoms where Ōsugi came out of prison and Itō came to Tokyo to work for Seitō. The cherry blossoms function, just like the ideas of love and freedom, as a pivotal point around which a multiplicity of perspectives come together. In this scene they also function as pivotal time that projects characters into past memories. While for Itō the blossoms enhanced her freedom and vitality, for her husband Tsuji, as he would declare later, the blossoms of that spring evoke only a cold wind. For Ōsugi, the cherry blossoms meant his first images of freedom after coming out of prison.

Associated with the motif of transience of beauty, the cherry blossoms stress the fleeting nature of passion and of life in general. The blossoms tower over Sakae and Itō with the intensity of a beauty doomed to perish and they dominate the frame while the heads of Sakae and Itō occupy the lower part of the screen. The metaphorical value of this image is stressed twice in the film through the poem recited by Ōsugi and later appearing as an intertitle punctuating Unema's suicide: "I danced amid the cherry blossoms in early March." This image functions as a time image that represents Eiko's imaginary reconstruction of the blooming of love for the Taisho characters. Nature imagery enhances and participates in the poignancy, beauty and 
transience of passion, in contrast with the dark studios inhabited by the characters in the 1960s.

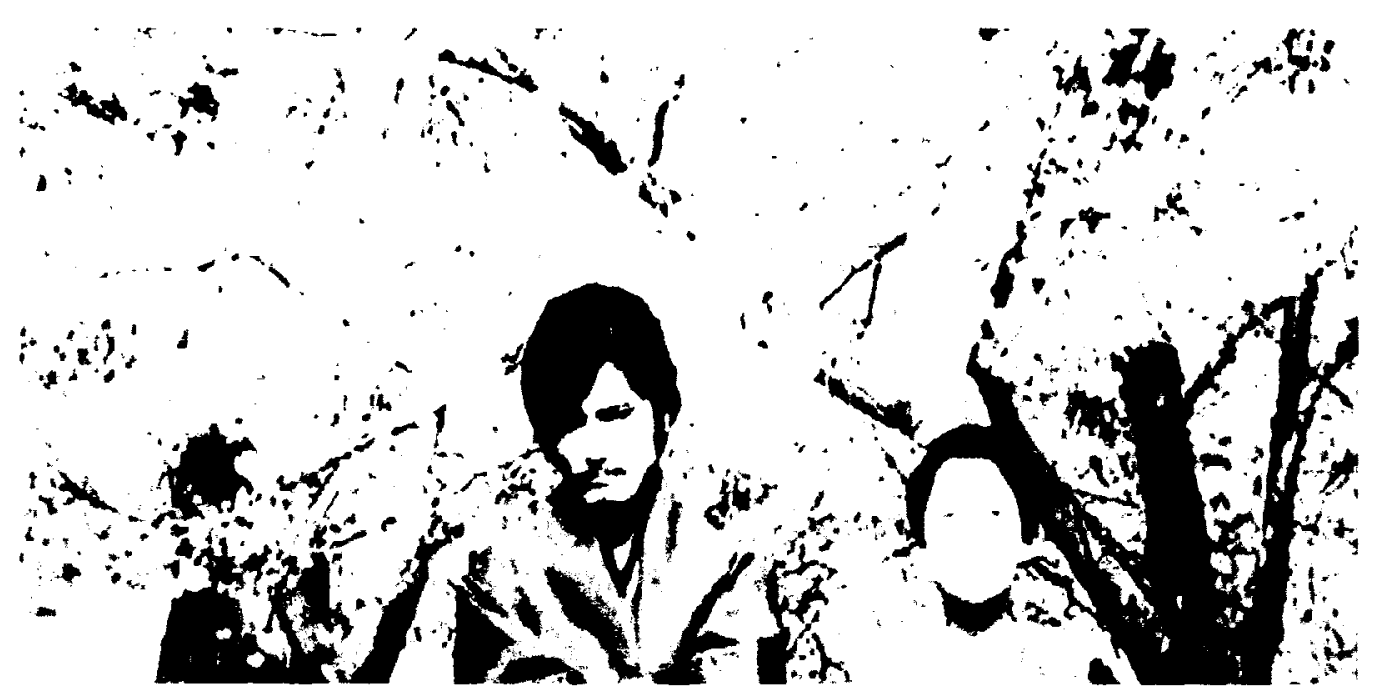

The cherry trees stand as a symbol of the evanescence of beauty, life and love. They tower over the characters highlighting the full blooming of their love but also the pathos of its evanescence.

Free love and sex available to the youth of the 1960s through Japan's historical transformation was a dangerous anti-establishment discourse for people in the $1920 \mathrm{~s}$ that led not only to social scandal but also to their annihilation through brutal murder. Ōsugi Sakae was an anarchist who fought against the rules imposed by the state insisting that political freedom started with free love. He argued against private property and monogamy stating that people could not be entirely free unless they liberated their sensibility and their bodies. He followed these ideas in his private life, which ended in tragedy. Married to Hori Yasuko, Ōsugi had two lovers, Kamichika Ichiko and Itō Noe. Ōsugi, Itō and his nephew, Tachibana Munekazu, were arrested by the military police after the Kanto earthquake in 1923 and murdered for their ideas.

Itō Noe was the editor of Seitō for a year and she published numerous articles about women's liberation while also translating Emma Goldman into Japanese. Member of the peasant class, Itō was somehow ill fitted with the other members of 
Seitō, who were daughters of urban elite families. ${ }^{48}$ She was rebellious and outspoken about her criticism of the marriage system and her belief in women's freedom. Although there is a feminist continuity between Itō and Eiko, the women in the $1920 \mathrm{~s}$ are powerful rivals both in terms of their class differences and in terms of their love for Ōsugi. As Satō observes, the struggle between Ōsugi and his three lovers "made them even more aware of the desire for private ownership, in the sense of monopolizing a loved object, a desire they were supposed to have abandoned." ${ }^{49}$ The desire for free love led exactly to its opposite, as each lover tried to monopolize her relationship with Ōsugi. The ideal of free sexual love transforms individual emotions into tools to counteract the power of the marital system and ultimately of the state. However, the unequal gender positioning of Ōsugi and Itō lead them to different practices of free love undermined by constant practical pressures.

The theories espoused by Ōsugi and Itō as historical figures are particularly relevant for Yoshida because they reflect the same rebellious stances of fighting social restraints and creating a personal ethos that dominate the $1960 \mathrm{~s}$. He most particularly reflects the 1960 s radical vision as Arima Tatsuo notes, when he states that in the destruction of reality "it is not intellect but passion that ought to direct man's actions." ${ }^{50}$ Osugi's character compares monogamous marriage to the law of private property under capitalism advocating for the liberation of passion from social constraints. The film portrays the systematic failure of his ideas not only because of state control but also due to the impossibility to develop sexual relationships based on absolute equality and freedom. He formulates a philosophical declaration of free love

\footnotetext{
${ }^{48}$ See Jan Bardsley, The Bluestockings of Japan: Feminist Fiction and Essays from Seitō, 1911-1916 (Michigan: Center for Japanese Studies, The University of Michigan, 2007).

${ }^{19}$ Satō, Currents in Japanese Cinema, 96.

${ }^{50}$ Arima Tatsuo, The Failure of Freedom: A Portrait of Modern Japanese Intellectuals (Cambridge, Mass.: Harvard University Press, 1969), 62.
} 
under three conditions. "First, all of us should be financially independent. Second, we will all keep separate residences. Third, we will respect each other's freedom, which, of course, includes sexual freedom." None of these ideas could hold in reality due to economic and social constraints.

Despite the historical force of Ōsugi's figure as an anarchist and revolutionary, women's desires and personalities dominate the film's alternation of past with present and the visual scenes of the past. Women forcefully gaze back at the camera and the spectators. As Yomota notes, "the posture of two women lined up looking straight ahead in the same direction, will become a model posture in Eros + Massacre thereafter." ${ }^{51}$ This is most clearly visible in the scene where the young Itō meets Hiratsuka Raicho and they talk about feminism in Japan. Hiratsuka, on the right of the frame looks straight at the camera and states: "Until now Seitō was said to be a pastime of elite ladies. But women like you, born poor from a rural family are plenty in Japan. Your fight is not your own. We women should all join hands and do our best." Women's gaze is an expression of their subjectivity and an invitation for spectators to participate in it. The film opens onscreen space for each of characters thus highlighting a multiplicity of perspectives on love, sex and freedom.

Ōsugi and Itō are struggling subjects and they each articulate their position on love and revolution in different ways. In an interview with Chris Fujiwara, Yoshida criticizes Ōsugi's position. "So I consider the idea of free love proclaimed by Ōsugi to have actually been male-chauvinistic egoism. When you say that he looks macho, what I wanted to portray was not a male comic, but a male clown. His performance is more theatrical than the others; it is as if he were trying to call attention to himself. In

51 Yomota, "Genealogy of the Mother," 44. 
Japanese tradition, kabuki theater has that kind of performance that attracts attention to oneself." ${ }^{52}$ Ōsugi played in this film by Hosokawa Toshiyuki, masquerades the 1920 s masculinity in a self-reflexive way. He challenges the social norms of masculinity at the time and comes closer to the ideas espoused by women's liberation. Although both Ōsugi and the Seitō feminists argue for the liberation of love and sexuality from the constraints of the state, they diverge due to their gendered social position. Throughout the film, Ōsugi proclaims in various instances his belief in a social revolution that starts with a revolution of sensibility, the idea of free love. However, the scandal entailed by his relationship with three women estranged his colleagues who regarded it as a form of egoism and polygamy. In the film, the character is ambivalently portrayed as a male clown haunted by the impracticality of his beliefs and as an idealist revolutionary who grasped the relationship between national ideology and sexual relationships.

Okada dominates the reconstruction of the past through her powerful presence as an actress in the role of the central character. Itō Noe pursued her feminist ideals in her own life despite the danger and anguish she experienced. Love and sexuality were central concerns of the feminist circles in the 1920s because, like feminists in the West, they understood that the personal was political and they viewed the freedom of love and sex as a central freedom of the subject that has been denied to women for centuries. Love is portrayed as a contextual negotiation that involves various embodied subjectivities. Pursuing love as a form of freedom, Itô found herself in the situation where love came against her freedom and independence as an individual. I will analyze here three scenes that construct three different points of view undermining Ōsugi's ideal of free love as a fundamental freedom of the individual.

\footnotetext{
${ }^{52}$ Fujiwara, "Interview with Yoshida Kiju," 12.
} 
The differential representation of many characters' perspective is a strategy Yoshida employs to explore love as a form of interpersonal negotiation structured by unequal economic and social circumstances.

The first scene shows Ōsugi in prison talking with two other colleagues about anarchy and revolution. Toshihiko Sakai admonishes him for his theories of free love. "What you're saying does not go beyond the realm of the sensual and the literary. You seem to be advocating a philosophy of life (sei) but someone has said that the "sei" you mean is sex. ${ }^{\text {“53 }}$ While they talk about love, his wife comes to visit him. Played by Yagi Masako, his wife is the embodiment of the traditional Japanese wife. Her demure, gentle demeanor suggests serenity that comes from the perfect match between her social status as wife and her beliefs in the value of marriage. Ōsugi continues talking about his ideal of free love while the camera captures in a close up and later in a high angle shot his wife's pain. "I love Itō Noe too. I love my wife with all my heart but I cannot tie my spirit with her. If love is not free, it will die." His wife's gentle face is transfigured by pain and she stubbornly refuses his idea. "I don't hear you. I am your only wife." She clings to her socially approved status denouncing Ōsugi's idea of free love as a form of male selfishness. As we will see in the next two scenes, Ōsugi fails to love up to the promises of freedom offered by love in the relationships with both Masaoka and Itō.

The second scene shows Masaoka with Ōsugi who proclaims his love for Itō. Claustrophobic mise-en-scene with low ceilings and tight framing foreshadows the tension of their relationship. She is in the foreground and her expression is of intense jealousy and anger. He appeals to her intellect and reason as a liberated woman to

\footnotetext{
${ }^{53}$ In Japanese language, both life and sex are pronounced "sei" with the difference only appearing in the written ideogram.
} 
understand his ideas. When he puts on his coat to leave, she offers him money and bribes him to spend the night with her. His economic dependence on her is made clear in another scene where Itō comes to announce her separation. Masaoka looms over Ōsugi and Itō in a low angle shot when she cynically proves that his economic dependence on her left him no room for freedom. "People say you can't buy love with money but it's true. He's mine and if he leaves me I will kill him." Masaoka, his betrayed and hurt lover is not only the one who stabs him out of jealousy but also the one who points out the limitations to his idea of free love. In a reversal of the patriarchal figure, Masaoka claims ownership of Ōsugi because of his financial dependence. "You say wonderful things but reality is different. The reality of free love is only a scandal." We can see in these scenes that the female perspective on Ōsugi's idea of free love was of intense pain and jealousy. Masaoka also counteracts his idealism of free love with the reality principle, showing the construction of love by unequal economic and social circumstances.

After his wife leaves him Ōsugi remains with his two lovers, claiming to love them equally although he realizes he loves Itō more and he wants to break up with Masaoka. One scene epitomizes through bodily gestures the transformations that the idea of free love brings upon relationships. A high angle long take from outside portrays Ōsugi's dinner with his two lovers. They all eat in silence, in a tense atmosphere. After Ōsugi finishes his rice, he gives Itō the rice bowl to fill it but she doesn't notice him, to which he gives it to Masaoka who continues eating, uninterrupted. He then turns and puts rice in his bowl for himself. The scene shows Ōsugi's masquerade of his own ideas of freedom betrayed by his body language that refers back to women serving men as wives. He proves to be a male clown as Yoshida stated because he proclaimed to be faithful to his ideas but his reality was different. 
Love is for him an existential ideological instrument he uses to undermine the monogamous family and the institution of private property but he gets entangled in the messy reality of his ideals.

Unlike Masaoka who regards love as a form of ownership, Itō believes in love as a manifestation of individual freedom. She is representative of the New Woman that the feminist magazine Seitō was describing as financially and emotionally independent. Despite the fact that she loves her husband, she decides to leave him and her two sons. Tsuji Jun, her husband, warns her that love destroys freedom and she becomes painfully aware of the discrepancy between the two in her relationship with Ōsugi. Her dialogues with her husband are framed through multiple sliding doors, little open windows and the melancholy sounds of Jun playing shakuhachi, a space both of enclosure and openness, suggestive for their relationship. She wants to live the full potential of her body and mind as a feminist woman of great talent and beauty but she realizes that she can only be free if she is independent. Her solitude and internal struggle are represented by her gaze staring in the void and in a series of shots revealing "Noe walking in the rain; Noe sobbing; Noe pensive by the hedge of Ōsugi’s house." 54 She announces both Ōsugi and her husband that she will live by herself but haunted by a vision of Ōsugi's death she returns to live with him in the hope that she can still pursue her freedom even in love. Unlike Ōsugi's idea of individual liberation through the freedom of sexual love, sexual freedom for Itō is in contrast with individual freedom, due to the unequal context of sexual relationships.

The emotional and bodily revolution proposed by Ōsugi was short lived in his lifetime but it had strong echoes for the 1960 s generation, especially due to the

\footnotetext{
${ }^{54}$ Macdonald, Cinema East, 184.
} 
unsolved mystery of their assassination. The first wave of feminism in Japan shows women grappling with the same issues of freedom, love and family but their difficulties are more insurmountable than men's. Ōsugi can develop a relationship with three women but for Itō it is impossible to have a relationship both with Ōsugi and her husband. Moreover, she also had children, which greatly complicated her pursuit of self-realization through love and freedom. The repeated scenes of her discussions with her husband highlight her pain and guilt for abandoning her children.

At a political level the state is against the idea of free love since it threatens to dismantle the family and consequently the whole idea of the nation. Okada noted in her memoirs that, “in this film Ōsugi and Itō's age and the present of 1969 are aligned together. The students' free love is a mere pastime, not a dirty thing that deserves punishment. In this sense I think the film is an ode to the period when people could give their lives for love." ${ }^{.55}$ I find her reading of the film quite interesting, a reminder of the long tradition of beautiful loves that could only end in death in Japanese cinema. It seems as if death sanctified Ōsugi and Itō's free love and saved it from the scandal and the petty manifestations of jealousy, hatred, selfishness and pain. Their pursuit of their idea of free love was a quest for self-realization that came against multiple obstacles, not only due to the grip of institutional power but also due to the sacrifices and pain it entailed for many people involved. Their brutal murder that shocked the Japanese public in 1923 had a double outcome. It showed the advent of the power of the state over manifestations of individual freedom and sexuality that would find its perfect expression in the militarist period. It also elevated Ōsugi and Itō as pioneers of free love who sacrificed their life for it. In contrast to the courage of their love as an existential political tool, love in the 1960s revolves around love as sex,

\footnotetext{
${ }^{55}$ Okada, Joyū Okada Mariko, 346.
} 
a bodily pursuit of pleasure devoid of affective involvement. Eiko and Wada, the two young students create various scenarios of passionate sexual love that can appear only in the vicinity of death and they dwell repeatedly on the imagery of Ōsugi's and Itō's deaths. The trope of their deaths functions in the film as an invitation to passion and the celebration of life.

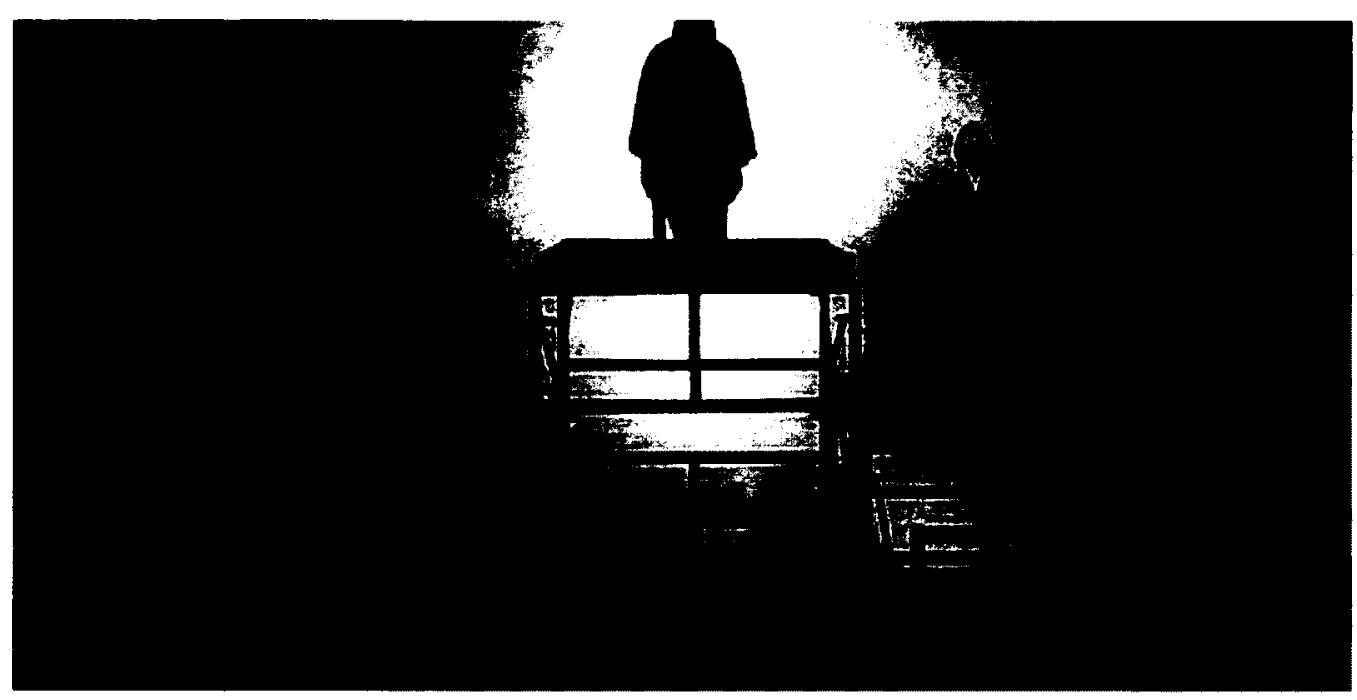

The deaths of Ōsugi, Itō and Tachibana are shot in a theatrical manner from various static angles that produce time expansion.

Similar to the film's construction of time images filtered through characters' subjectivity, love in the 1920 s is represented not through action but as an affective, unruly and culturally contextual flow, an existential belief revealed though the voices of characters and a political tool of freedom from state ideology. All three instances of love are represented through the filtering subjectivity of the characters. Free love is for the past characters a bodily and emotional transgression that could potentially free individuals from social constraints. At the same time it was also a dangerous and courageous emotion that brought grief and ultimately death. The film uses various means of representing love as an emotion that defies the direct visual representation of 
sex; voice, gesture, facial expression, elements of nature and sound. This representation of love constructs the affective dimension of the material body as an in between space of intensities. Love in the 1920s is not only a form of bodily desire but is instead the central engagement of characters with the world and with their own subjectivity. By giving voice and visual space to each of the characters and by showing love as a struggle between embodied subjectivities, the film enacts a feminist strategy that I outlined at the beginning of this chapter. There is no fixed standpoint in the film that would create a pattern of power, like the male gaze. Power is instead selfreflexively analyzed and contested through the presence of conflicting male and female points of view. In the following part I will analyze more closely the mechanisms of mediation between the two time periods. Although there are instances where the representation of the Taishō period functions as time image, as I have shown at the beginning of this part, the film challenges spectators to abandon the stability of Eiko's present.

\section{Bodies in Continuous Time-In Search of a Feminist Legacy}

The mediation between past and present is secured by Eiko's imagination and her search for a continuity of feminist legacy, which underpin the editing sequences of the film. The force of mediation as a propelling forward through past lessons is double, both for the character and for the filmmaker. The 1960 s are the reference time point for Yoshida, who tries to make his generation intelligible through its dialogue with the past but at the same time the 1920 s becomes a reference point of value that allows him to critique the present. I will analyze here how the film frames the interlacing of past and present not only through editing like the time images I have outlined above but also through mise-en-scene and the construction of time as duration. 
Unlike the phenomenon observed by Gluck as "mythistoric postwar" in which the postwar present is constructed through opposition to and denial of the past, the film posits the past as a fertile context of meaning and continuity. ${ }^{56}$ However, there is a gendered difference in the meaning of time and history. The past is searched out as a legacy of ideas of free love and female liberation, a ground of meaning for the young women in the 1960s. On the other hand, Wada refuses to know, he lives in the denial of the past shown by Gluck and which has been theorized as a trait of the Japanese postwar (male) ideology. Eiko's story is situated under the sign of women's genealogy, starting with an interview of Itō's daughter. She undergoes extended interrogation for the crime of prostitution and answers that her unhappiness comes from her murdered mother, who taught her that life was to be fought, not lived. This genealogy creates time continuity from the struggle of women in the 1920 s to the 1960s. Unlike Wada who is not interested in the past, Eiko looks for the meaning of love and sexuality as expressions of freedom and self-discovery. Wada is haunted by a sexual trauma and he manifests his desires through repression and forgetfulness. His trauma is an embodied metaphor for the male trauma produced by Japan's loss of war and subordinate status in a global order. ${ }^{57}$ This male trauma also appears for the male character of Hani's film, Nanami: The Inferno of First Love, which I will analyze in the last chapter.

There are various scenes in the film that connect Eiko and Itō not only through the montage of time images summoned by Eiko's imagination but also through their placement in the same frame. This framing together of two characters living in different time periods creates a cinematic time continuum constructing the feminist

\footnotetext{
${ }^{56}$ Carol Gluck, "The "End" of Postwar: Japan at the Turn of Millenium," In Public Culture, 10, no. 1 (1997): 1-23.

${ }^{57}$ See Saito Ayako, "Ushinawareta farusu wo motomete," [Reclaiming the Lost Phallus] In Eiga no seijigaku [Film Politics], eds. Hase Masato and Nakamura Hideyuki) (Tokyo: Shosha, 2003).
} 
legacy sought after by Eiko. She reconstructs the embodied history of a feminist figure in order to make sense of her own desires. This co-presence of two women from different time periods in the same frame have a different function than the time images summoned by Eiko's imagination. I will analyze here three scenes that connect the past with the present within the same frame, showing an embodied continuity of time.

The first scene shows Wada and Eiko in Unema's film lab. Wada wants to break up with Eiko since he is not interested in the past like she is. They come in the lab where the camera is placed and Eiko takes Unema's lighter and starts lighting film strips that hang from the ceiling. The flame, which I pointed out previously as a symbol of passion and vitality, activates Wada's memory and he finds similarities between the filmmaker with the man who abused him as a boy. In the low-key, darkened room he picks up a book and starts reading an account of Itō and Ōsugi's daughter's experience of her parents' death. Meanwhile, Eiko projects images of devastation and people dead in the Taisho period earthquake on a screen and the space of the film becomes her own. These projected images are edited together with the theatrical mise-en-scene of Ōsugi and Itō's murder. In a technique similar to Noh theatre, white-gloved hands slowly strangle Ōsugi, Itō and their nephew. Their gestures are edited together as stills against the melancholy music that punctuated both the scenes of love and of death for the Taisho era characters. Returning in Eiko's present, the film presents the projections of newsreels showing the aftermath of the Taisho era earthquake as part of the film itself. They fill the frame and spectators become directly witnesses of death and destruction, without the mediation of Eiko's subjectivity. Wada points out the meaninglessness of searching for the past. "What did you want to discover on the dusted shelves of a library? The past? History? Memory? 
Pride? A sense of community (kyōyōkai)?" He throws the book and rejects the past in a rebellious gesture reminiscent of the students' protests but Eiko stands again the screen and the images are projected on her body. We can read in this scene women's embodiment of history and their desire for continuity and legacy despite death and the passage of time. This continuity occurs on two planes: cinematic images/books/ photographs or other forms of discourse and female bodies. While the former plane is present and available for viewing, history inscribed on the body (and its affect) haunts Eiko, who struggles to understand it. History cannot be wiped out as Wada believes since it lives on through the embodiment of a new generation. The death of important historical figures marks Eiko's body with the melancholia of life's transience and the desire for equality in sexual relationships. While the imaginary construction of the 1920s period appeared as time images through the subjective reconstruction of time, in this case Eiko uses cinema to get closer to the meaning of death that can both enhance love and destroy it. In this scene, she does not create images but instead, the images create her by inscribing time and history on her body.

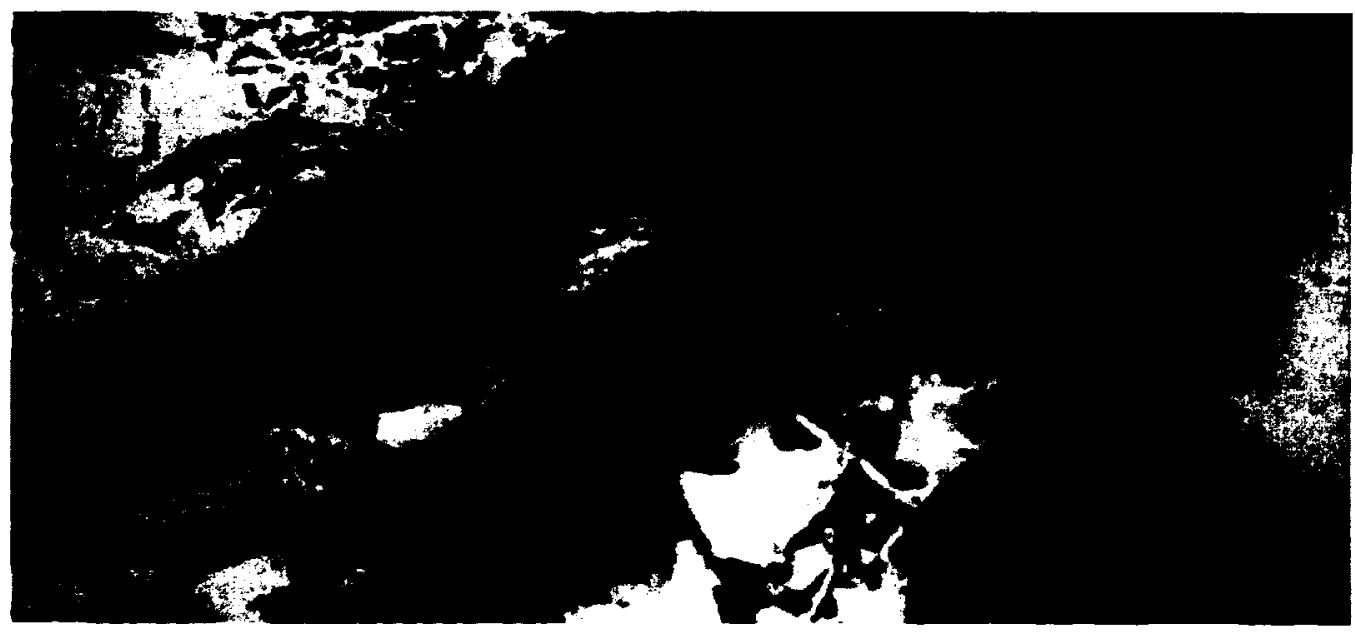

Eiko stands in front of the projector that superimposes images of destruction on her body, a scene that highlights the embodied continuity of history. 
The second scene shows Eiko interviewing Itō with a microphone in modern day Kyoto, both women represented through a tracking shot as they walk across a grass covered wasteland. Eiko asks Itō about whether she could have avoided death if she had not pursued Ossugi. The meaning of Itō's pursuit of love and freedom acquires tremendous weight in light of her death. Eiko's presence situates the time of Itō's life in the context of a destiny influenced by personal actions, in line with Yoshida's interest in existentialism. Itō talks as a visionary who has seen the future and accepts the consequences of her life choices. The resurrection of the past performed by the film (and by Eiko's imagination) defies the linear time of existence turning it into a spiral where present and past come together through the presence of bodies in two different time periods in the same frame. This scene shows an interesting construction of the cinematic defiance of the body's vulnerability to time, of death in other words. The body's limited existence in time marks an important gap between cinematic construction of bodies and real bodies. The film creates time as duration by bringing women from two different time periods in dialogue.

As they walk toward the camera the two women's faces appear in a close-up. Eiko asks Itō: "What do you think about the period of 46 years between 1923 and 1969?" Itō does not answer but the close-up of her face reveals the transformation of happiness into pain and anguish. She turns and has a vision of her former husband, Tsuji walking along with their son. This vision of loneliness and sadness fills her with pain and frightens Eiko too because it reveals the difficulty of free love for women, the guilt and pain brought about by their search for freedom. The same image evokes the future for Itō and the past for Eiko. The image summons not only an embodiment of the past but it also gives voice to the emotions of the characters in the past through the montage of Itō's vision that Eiko (together with the spectators) witnesses. Both 
women gaze at the legacy of loneliness and pain against a melancholy soundtrack. This vision is melodramatically highlighted by a cross that dominates the frame suggesting the intertwining of love with pain. Through this scene the past turns into its future and it is contemplated as a continuous present where bodies are not marked by the vulnerability of death.

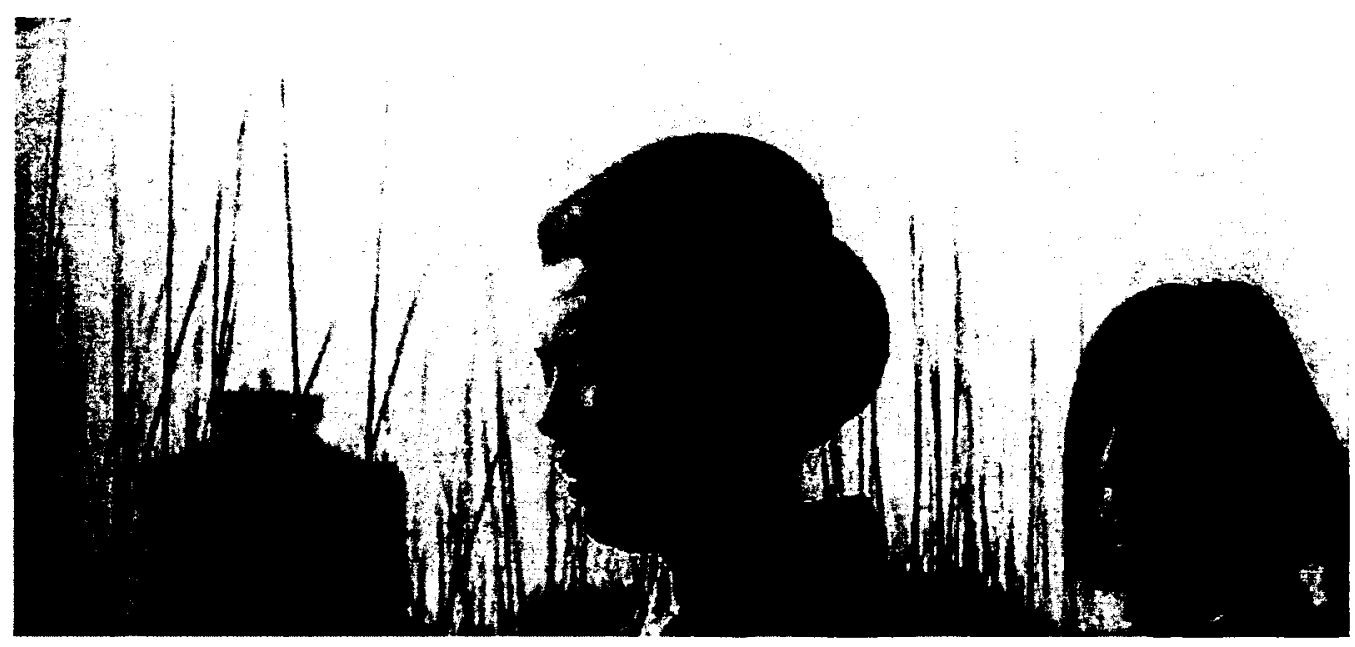

Ito and Eiko are present in the same frame, a surreal cinematic construction of time as continuous present.

Another scene that situates the two women in the same frame is Eiko's witnessing of the deaths of characters in the 1920s. Unlike the preceding scene that defied death by putting Itō into direct dialogue with Eiko, this scene makes Eiko experience the trauma of death, which gives her the desire to live and love. The three bodies of Ōsugi, Itō and their nephew are arranged in a circle, as MacDonald noted, "like petals of a flower." 58 This arrangement reinforces visually the motif of the transience and fragility of blossoms and implicitly, of human embodied life. While Sakae's friend mourns their death, Eiko comes close to Itō, kneels down and asks her about the cause and meaning of her death. Through a montage of her imagination, we see the three characters standing but when she approaches them, they turn back into corpses. Eiko reconstructs the past through her imagination but the trauma of bodily

\footnotetext{
${ }^{58}$ MacDonald, Cinema East, 194.
} 
death prevents her for understanding directly the emotions and embodied subjectivities of Ōsugi and Itō.

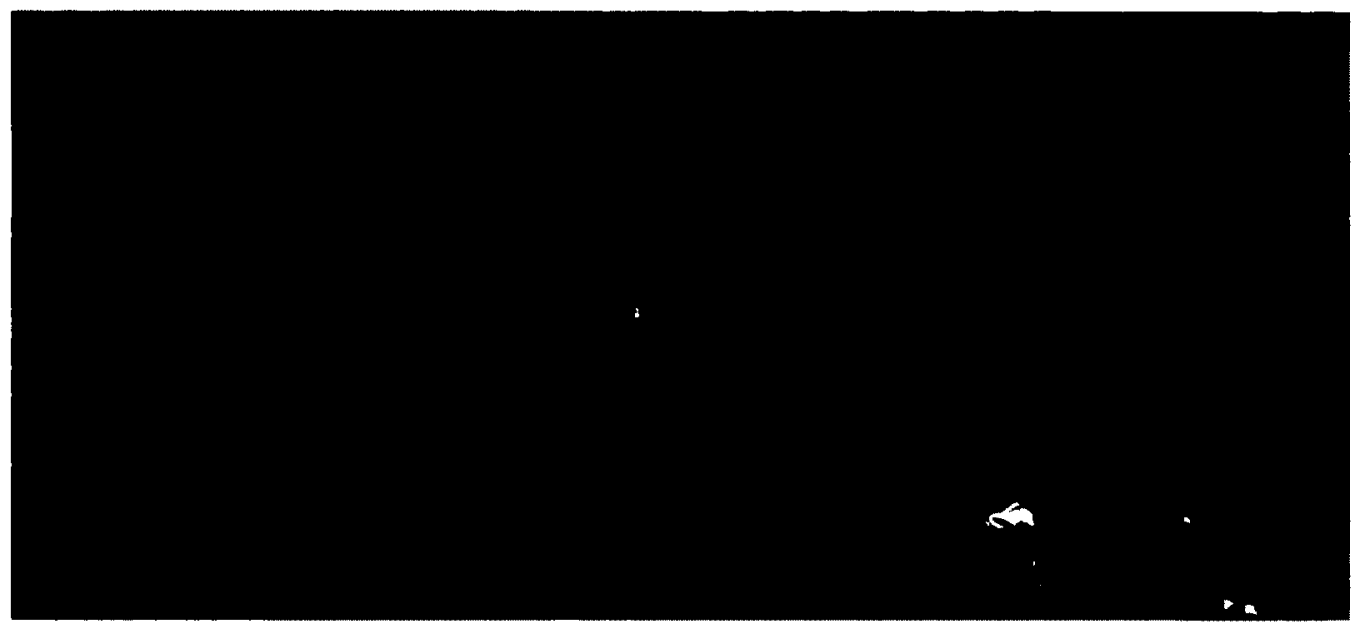

Eiko kneels down near the petal shape arrangement of the dead bodies of Ôsugi, Ito and Tachibana, interrogating the cause of their deaths.

In a self-reflexive manner, all the characters of the Taisho period line up in front of a camera manipulated by Eiko and Wada in the last scene of the film. "This picture will become a great monument," says Wada. They both step outside in the light shutting the door of the studio that suffuses the frame with darkness. How can we interpret this ending of the film? Did the characters in the 1960 s learn from the past the need to combine sex and love rescuing the body from commodification? Did they learn that passion/love could only appear in the vicinity of death and the melancholia produced by the body's vulnerability to time? Desser offers a profoundly elegiac reading of the relationship between the Taisho period and the 1960s. "The spirits of Itō Noe and Ōsugi Sakae resurfaced not to haunt the 1960s generation but to inspire it. But haunt them it did nevertheless as, like Sakae and Itō, the 60 s generation passed away, killed not by the brutality of the militarists but by the more insidious forces of economic cooptation and intimidation." ${ }^{59}$ While the film critiques the

${ }^{59}$ Desser, Eros + Massacre, 212. 
alienation brought about by the commodification of desire, including the cinematic apparatus, it also offers a glimpse of hope in the love relationship between Wada and Eiko as two subjects who have come to terms with their sexuality and their emotions.

\section{Conclusion}

I have argued in this chapter that the film Eros + Massacre employs feminist strategies by representing love as an open, contextual negotiation between male and female subjectivities both in terms of its cinematic strategies and in terms of its narrative. It offers a multiplicity of perspectives on love and sexuality from the state power to the negotiations between embodied subjectivities. Yoshida also negotiates his power as a male director versus actresses and represented women through his theory of self-negation as an ethical engagement of the self with the Other.

The film constructs time from the subjective perspective of a female character as time images or duration, where past, present and future coexist. Through editing it creates time images that bring the past into the present mediated by a character's subjectivity. Through its mise-en-scène and framing, it explores embodied time and the role of cinema to both defy death and bring it closer to the viewers. By resurrecting the historical figures of the anarchist Ōsugi Sakae and feminist Itō Noe, the film addresses the alienation felt by the youth in the 1960 s who experience the commodification of desire that alienates the body from affect. The unification of sex with love implies the unity between mind and body as a form of coming to terms with the past that is invisibly inscribed on bodies. I followed in my analysis of the film both personal and political aspects of sexual love. Manifested as a form of personal freedom it also implies state control and continuous negotiations among subjectivities determined by gender and class structures. Yoshida's film self-reflexively analyzes the role of cinema in the representation of bodies in time and bodies in love. 
Chapter Five. Love and Power, The Appropriation of the Adolescent Body in Hani Susumu's Nanami, Inferno of First Love (Nanami, hatsukoi jigokuhen, 1968)

Where love rules, there is no will to power, and where power predominates, love is lacking. The one is the shadow of the other.

Hani Susumu is best known for his two documentaries about children interacting in the classroom, which he produced at Iwanami publishing house in the 1950s. Similar to Imamura, he experimented with cinematic technique using documentary strategies such as hand held camera, nonprofessional actors and counterpoint sound in his fiction films like Bad Boys (Furyō shōnen, 1960), A Full Life (Mitasareta seikatsu, 1962), Nanami, The Inferno of First Love (Nanami, hatsukoi jigokuhen, 1968). According to Abe Mark Nornes, he revolutionized the Japanese documentary, inspiring some of the best-known documentarists to join Iwanami productions. ${ }^{2}$ His main interests are children and women, memorably portrayed in many of his films. Both children and women are vulnerable to oppression and to forms of power that take away their potential as human beings through the disciplining of their bodies and subjectivities. For this reason Hani can be considered a humanist who critiques Japanese society through his alliance with the powerless. Similar to Imamura and Yoshida he creates a politics of gender and sexuality through his critique of the family and of the male gaze as a means of objectifying the female body. This critique comes from the vantage point of individual growth and selfawakening appropriated by oppressive structures of power that produce alienating forms of sexuality. While Imamura offers a penetrating critique of changing social institutions in Japan such as the feudal family and prostitution, and Yoshida portrays the existential problems of intellectuals, Hani offers a profound understanding of the

\footnotetext{
' Carl Gustav Jung, On the Psychology of the Unconscious, tr. by Beatrice M. Hinkle (New York: Dover Publications, 2003), 315.

${ }_{2}^{2}$ Abe Mark Nornes, Forest of Pressure, Ogawa Shinsuke and Postwar Japanese Documentary (London and Minneapolis: University of Minnesota Press, 2007), 15.
} 
human psyche and the role of sexuality in the development of the self and its interaction with the world.

In this chapter I will analyze Hani's feature film, Nanami, The Inferno of First Love, focusing on the duality between sexual love as a source of liberation through a mutual engagement with the Other and the power of sexual desire as a form of appropriation of the Other's body. I will refer to appropriation as a means of shaping bodies, desires and subjectivities through unidirectional sexual relationships that exclude consent and mutuality. I chose this film for analysis because it represents both at a narrative and at a formal level the dualities highlighted in this dissertation: the body as subject and object, the look and the gaze, the camera as a form of objectification of the body and one of exploration. I argue that the film critiques the objectification of the female body and the eroticization of violence through the ideal of adolescent love that allows for sexual desire without the separation between the body as subject and the body as object enacted by the male gaze. Cameras, both the film camera and photographic cameras are self-reflexively represented as extensions of the male gaze that turns the female body into an erotic object. I will show that even though the film critiques the appropriation of the female body by the camera, it also reenacts it. Through its representation of sexual relationships and unconscious affect, the film portrays sexuality as a mode of being in the world that shapes human interactions. More specifically, the film represents the sexual body through the duality between love as mutual fulfillment and power as a form of sexuality based on the objectification of the Other. The representation of unconscious affective states in Hani's film highlights tbe fluidity of the self, permanently open to transformation and vulnerable to power. I will explore the issue of power surrounding sexual trauma and the objectification of the female body. 
The duality between the look and the gaze inherent both in the film's narrative and in its visual representation explains the controversial reception of the film as an artistic masterpiece and as commercial exploitation. Jasper Sharp observes that the film "may have rivaled pink film in terms of the amount of bare flesh on display," although the different production and distribution venues exclude it from the category of pinku film. ${ }^{3}$ To what extent is the style of the film working through scenes of nudity, sexual encounters and $\mathrm{S} / \mathrm{M}$ scenes to perform a critique of the male gaze? In a manner similar to Eros + Massacre, Hani's film critiques the power of the male gaze pervading the visual representation of the female body in postwar Japan, while at the same time participating in its eroticization.

Similar to Imamura and Yoshida, Hani represents the body as an interface between social power and emerging subjectivity. However, unlike Imamura and Yoshida who explore the body and sexuality through a larger view of their involvement in the historical institutions of the feudal family, state and social hierarchy, Hani's film zooms in on sexual relationships and the unconscious forms of affect they produce. The result produced by this exploration is the representation of the construction of sexuality, inherent not in the body's nature but formed through interpersonal relationships. Time images called forth by Yoshida's "seer" characters are represented in Hani's films as images of the unconscious. We are invited to see beyond the available surface source of visibility, to the unseen layers of unconscious desires and traumas, a mode of seeing that we can refer to as the look. Film scholar Tsunoda Takuya has suggested that "Hani's conceptualization of cinematic experience - as a progressive, participatory and synthetic process of interaction that the subjects go through - seems to echo a phenomenologist approach that stands upon

\footnotetext{
${ }^{3}$ Sharp, Behind the Pink Curtain, 12.
} 
a fundamental distrust of a uniform mode of consciousness based on rational and schematic explanation of human interiority." Human interiority is shown in this film as a continuous interaction with the outside world through the mediation of the body, a process I also highlighted in the previous chapters on Imamura's films. The look does not define but instead shows the body as a transformative process of interaction with the world.

The film plunges us deep in traumatic childhood experiences and exposes the ways in which they shape love and sexual desire. The film represents the emergence of sexuality for an adolescent boy and the exploitation of sexuality for an adolescent girl, whose relationship is haunted by their personal experiences of objectification. Shun, (Takahashi Akio) is a young boy who has been abandoned by his mother and raised into an adoptive family where his stepfather sexually abused him. Nanami, (Ishii Kuniko) is a young country girl working as a nude model who tries to make a living in the alienating urban life of Tokyo. Their first encounter is a failed sexual act under the sign of prostitution but as they learn more about each other, both of them try to escape their oppressive conditions through the ideal of sexual love as a form of liberation. Love is promise of happiness, fulfillment and freedom from psychological trauma and impotence for Shun and from the sexual objectification of her body for Nanami. The sexual dimension of the bodies affected by love is seen as a form of mutual engagement with the Other through the integration of subjectivity with the body. This dimension is in conflict with the sexual dimension of the bodies affected by power, which transforms the Other into an object of desire. The narrative of Nanami, The Inferno of First Love shows the body as subjected to power and as a site

\footnotetext{
" Takuya Tsunoda,"Toward Human Experience: Hani Susumu on Cinema and Subjectivity," essay to be published in 2013,21 .
} 
of resistance against it, a binary that has plagued many theoretical accounts of the body.

The body is both the site of disciplinary power and the source of opposing that power, a duality pointed out by Elisabeth Grosz as the main point of theoretical divergence between Michel Foucault and Friedrich Nietzsche's accounts of the body. "Where for Foucault the body is the field on which the play of powers, knowledges and resistances is worked out, for Nietzsche the body is the agent and active cause of knowledge. ${ }^{65}$ The quote at the beginning of this chapter points out to the same mutual exclusiveness of power and love but I will argue that the film shows their mutual coexistence both in the narrative and in the cinematic strategies used by Hani. The disciplined body is the body of Nanami as a nude model and an actress in S/M scene, and Shun's body, sexually abused by his stepfather. The resisting body is animated by love as a form of liberation predicated on mutuality, agency and affective involvement in the sexual act.

In this film, power is envisioned as the supremacy of male desire supported both by social and economic inequality and by systems of representation that produce erotic bodies. This power affects both women and children through the alienation of their bodies from their potential for pleasure and self-determination. Resistance to power takes the form of love as an opening of the self to the wonder at the alterity of another person, a form of ethics that is liberating both for the self and for the other. I will focus in the following part on the duality (some would say mutual exclusiveness) between nakedness and nudity in order to explore the role of the male gaze in the objectification of the female body as a form of sexual appropriation or disciplining of female subjectivity. I will argue that Hani self-reflexively portrays the objectification

\footnotetext{
${ }^{5}$ Grosz, Volatile Bodies, 146.
} 
of the female body enacting a critique of the camera while at the same time extending that objectification. The naked body existing in itself as the embodiment of human subjectivity is constructed by technologies of the male gaze supported by the cinematic camera and turned into a nude.

\section{Nakedness and Nudity, The Body in Itself and the Body on Display}

The numerous nude shots of The Inferno of First Love led some critics to find similarities between this film and Wakamatsu Koji's pornographic work. ${ }^{6}$ Is onscreen nudity always a sign of the male gaze that objectifies women? This question raises important issues about the apparatus of cinema and its tense relationship with the female body. As Mary Ann Doane shows, "cinematic images of woman have been so consistently oppressive and repressive that the very idea of a feminist filmmaking practice seems an impossibility. The simple gesture of directing a camera toward a woman has become equivalent to a terrorist act."7 The repeated accumulation of representations of eroticized female bodies makes it almost an impossible task to reveal other meanings outside their enticing sexuality. The same accumulation of erotic dimension of the bodies that overwrites nakedness is pointed out by one reviewer of the film when referring to the shots of naked children inserted in the scene of Shun's reverie. "Though indeed controversial (in light of today's serious problem with child pornography), Hani's documentary-like scenes of naked children playing together, uninhibited and devoid of awareness or concern for adult societal machinations, ultimately communicate a very powerful and stark juxtaposition... between what humans are in and of themselves and what society and

\footnotetext{
"htp: "1t wharudamacom/japanese_movies inferno.shtml, August 18, 2012.

${ }^{7}$ Doane, "Woman's Stake: Filming the Female Body," 216.
} 
culture finally makes of them." In Shun's reverie scene, still shots of naked children running in the temple grounds wearing Tengu masks alternate with long takes of rows of children playing naked and uninhibited by their nakedness. ${ }^{9}$ The following shots show stills of children's faces put into movement by the panning of the camera from their faces to their girl and boy bodies. The representation of children's nakedness points out the freedom of the body in itself, the body that has not been inscribed by social norms of power.

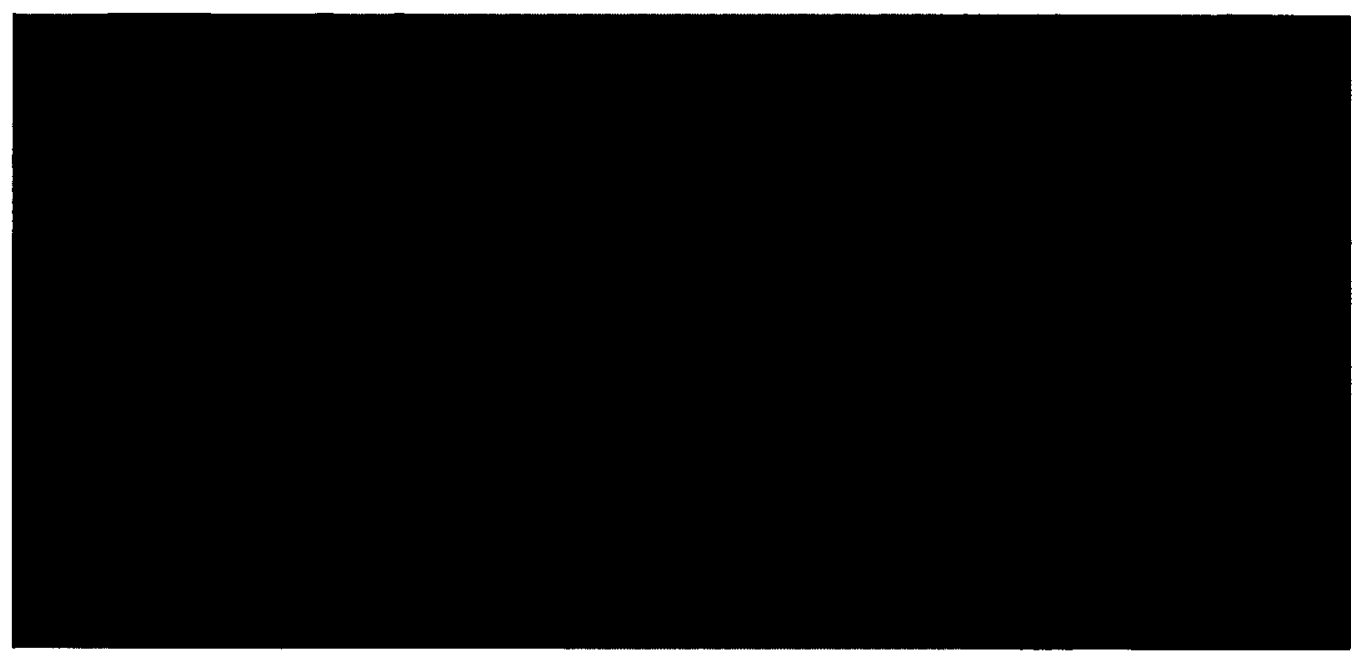

This image is part of Shun's memories of an innocent and uninhibited childhood when nakedness is not yet colonized by sexual norms.

The film portrays the duality between nakedness as mark of innocence, vulnerability, human presence and nudes as sexually objectified bodies. In order to explore this ambivalence I will turn to John Berger's distinction between nakedness and nudity. "To be naked is to be oneself. To be nude is to be seen naked by others and yet not recognized for oneself. A naked body has to be seen as an object in order to become a nude. Nakedness reveals itself. Nudity is placed on display... The nude is

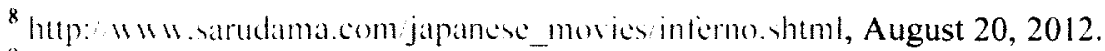

${ }^{9}$ The Tengu is a Shintō deity.
} 
condemned to never being naked. Nudity is a form of dress." ${ }^{10}$ The representation of Nanami's body shows the transformation of nakedness into nudity. Her body is put on display for men who pay to watch it but it is also put on display in the film. Does this mean that the film reinforces this transformation by participating into an objectifying system? As Nina Cornyetz observed, the 1960s in Japan was a period marking legal representations of female nudity both in cinema and in other forms of media. Both the lifting of censorship on sexual representation and Hani's independent production made possible the bold representation of sexuality in the film. I argue that the film portrays both the nakedness of the body and its eroticized nudity, enacting a dual form of representation of the body as subject and object. The film self-reflexively explores the technologies of erotic gazing that transform the naked body in itself into a nude body aimed for viewing pleasure. Similar to Eiko in Eros + Massacre, Nanami is a presence that communicates her sexuality but also her subjectivity. The film counteracts her objectification as a nude model through accumulated details about her interiority. Models are also shot naked when they are not posing for customers, performing daily activities like eating and watching TV. In this context nakedness is devoid of its erotic potential.

The first nude that appears in the film is a nude painting shot in close-up in the room where Shun and Nanami enter. This shows the long history of nudity present in art before the advent of cinema and it implies the historical coding of female nakedness with sex. The close-up of the painting begins and ends their sexual encounter. Another shot inserted in the moment of Shun's sexual fantasy shows a close-up of Nanami's childlike face holding the enlarged nude painting that was present on the wall of the room.

\footnotetext{
${ }^{10}$ John Berger, "Ways of Seeing," In The Feminism and Visual Culture Reader, ed. Amelia Jones, (London and New York: Routledge, 2003), 51.
} 


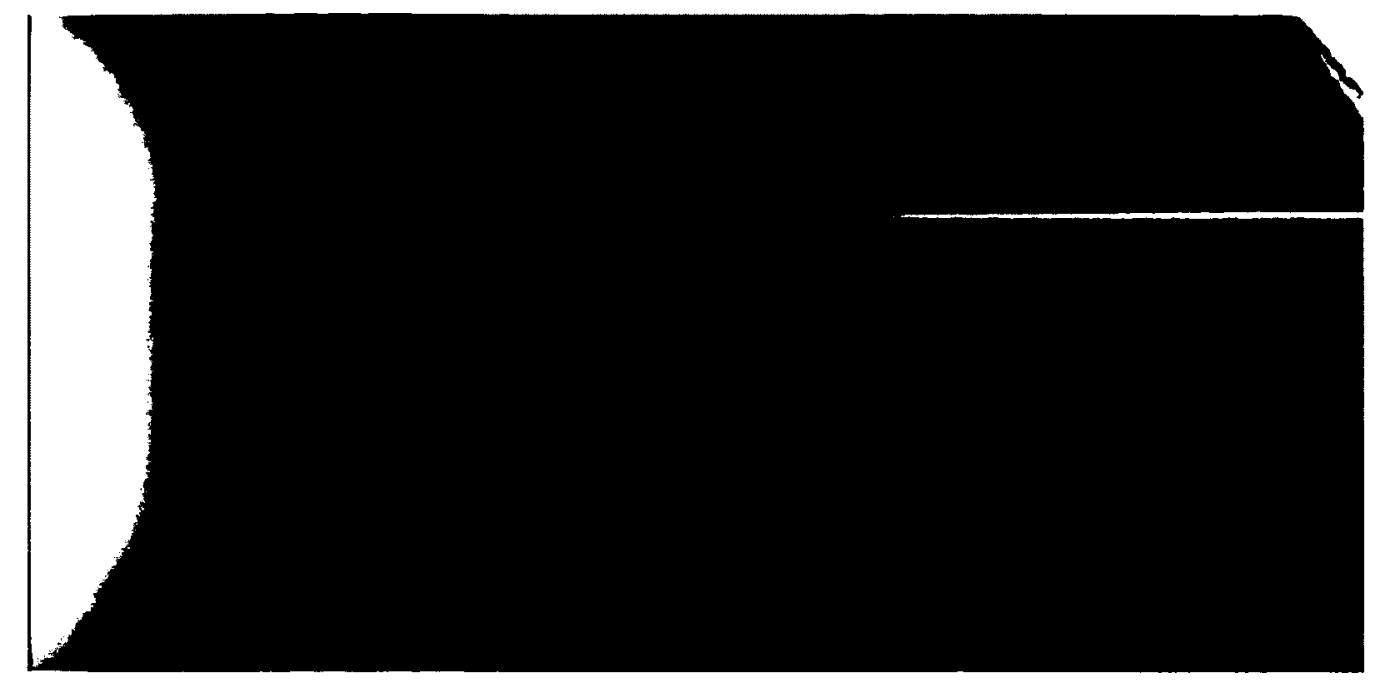

The nude replacing Nanami's body reflects the long history of the sexualization of the female body, both in art and in cinema.

Nanami gets undressed reassuring Shun that she is used to the cold because she is a nude model. As Berger has shown, "the self-surveyed woman turns into an object of vision, a sight." She manipulates the erotic potential of her body because it is this potential that offers her a place in the world and she successfully internalizes the male gaze, much like Imamura's heroines internalize social norms that reduce them to their sexualized bodies. Vivian Sobchack has shown that "in being constituted and treated as an object...the body-subject "suffers" a diminution of subjectivity and, in this diminution, comes to experience-within subjectivity-an increased awareness of what it is to be a material object." ${ }^{12}$ Working as a model allows her to escape the dire conditions of poverty for girls moving from countryside to Tokyo but this work transforms her subjective interpretation of her body, that becomes an object for her as well. However, Nanami's body radiates freshness and youthful innocence rather than sex. The film highlights the discrepancy between her innocence and the eroticization of her body. When she tells Shun her life story, we see models posing for men.

\footnotetext{
"Berger, "Ways of Seeing," 50.

${ }^{12}$ Vivian Sobchack, Carnal Thoughts: Embodiment and Moving Image (Berkeley: University of California Press, 2004), 288.
} 
Panning shots of nude models are edited together with aestheticized shots of bodies overwritten by shadows and close-ups of women's eyes. It seems as if the images are trying to transcend the sexual dimension of the bodies and capture something else, the embodied presence of a human being, the body as a source of possibilities. The film makes visible the act of modeling itself when women trace the boundaries of what men are allowed or not allowed to do. The eroticism of the bodies is based on demarcating boundaries and it is restricted to voyeurism, but the film shows that women's integrity of their bodies is an illusion. From the model position, women easily turn into prostitutes and porn actresses. I will analyze two scenes that selfreflexively represent the transformation of the naked body into a nude.

The first scene shows both narratively and visually Nanami's entrance into the modeling job. She starts telling Shun about her life story, how she came to Tokyo from Shizuoka and she worked in a shoe factory that paid her a very low salary. Her story is replaced by visual images reconstructing her memories. Two women introduce her to the model job and the sound grows disturbingly ominous until it changes into light-hearted music accompanied by still nude shots and shots of Nanami dancing and moving her semi-nude body. Ankokuji (Yuasa Minoru) watches her at the opposite angle of the camera, while Nanami is posing, conscious of his gaze. 


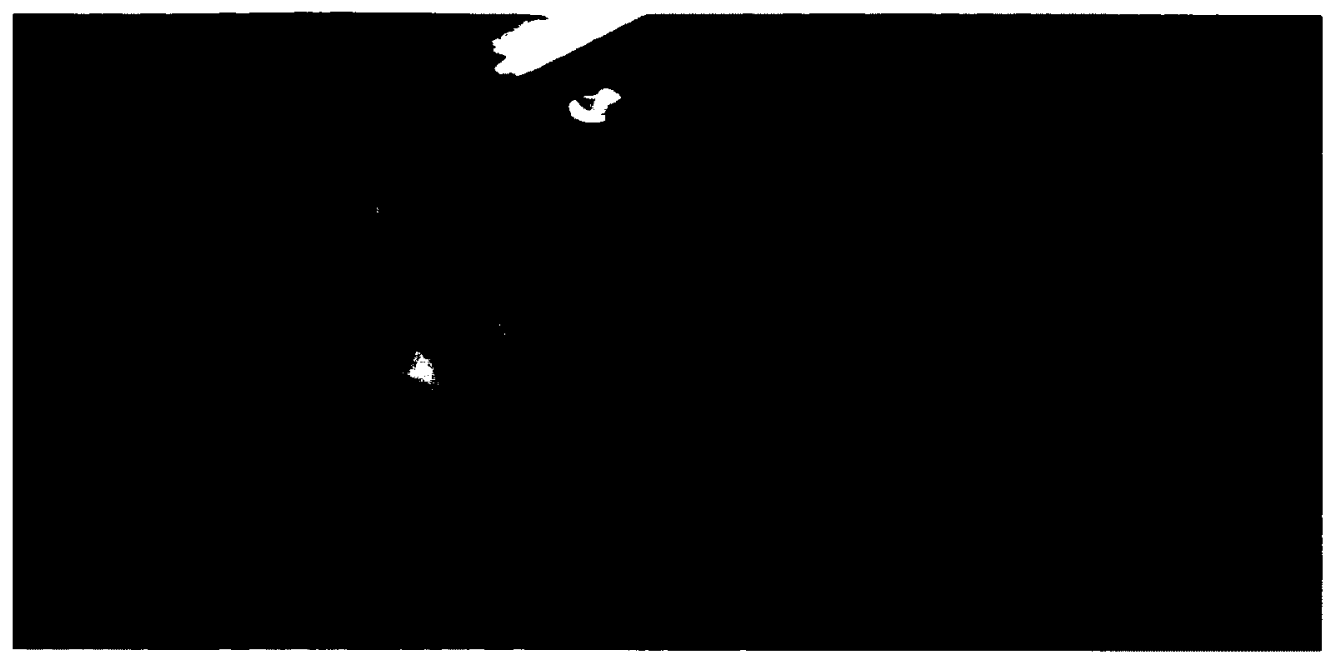

Nanami is self-consciously posing for Ankokuji, aware of the fascination provoked by her body. She poses both for the man and for the camera although the camera position self-reflexively reveals the formation of the male gaze. It makes us look at the gazing man.

Another scene shows a woman modeling. The camera is placed behind the men and we see how they barter. "We paid for you so lie down. Open your leg, More, More. Come closer. Take off your panties, it's not interesting if you don't take it off." 3 The position of the camera that allows our viewing of the men in the process of voyeurism is a self-reflexive representation of the male gaze. When the models go for a shooting session by the sea, the shots alternate between views of the camera placed behind the men who take the pictures, in their place and behind the women, thus making spectators aware of the presence of embodied males behind the camera, and also destabilizing the male gaze. This position of the camera undercuts the voyeurism criticized by Mulvey, which is predicated on the alignment of the camera with the male gaze. ${ }^{14}$ Instead, the mise-en-scene reveals voyeurism itself, making difficult the identification with the male gaze. Instead of erotic female bodies, we see how bodies are eroticized, in a manner similar to Imamura's representation of the becoming of woman through the disciplining of the body. This discipline is based on the

${ }^{13}$ Nanami, The inferno of First Love.

${ }^{14}$ See Mulvey, "Visual Pleasure and Narrative Cinema." 
transformation of woman into an object body that must respond to male sexual desire, whether as prostitute or erotic/pornographic model.

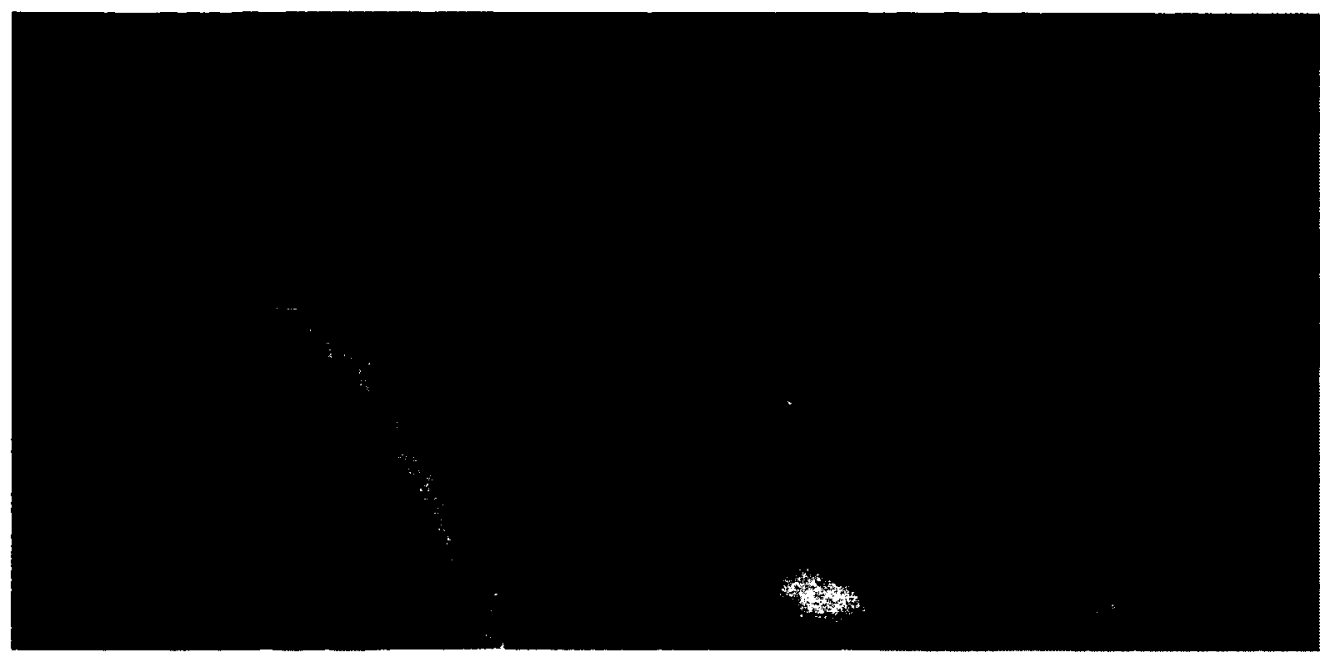

Similar to the snapshot above, the camera captures the eroticization of the female body, occupying a place of intimate proximity to women. We align not with the male gaze but with the women being gazed at.

The self-reflexive representation of male desire shows the multiple forms of power involved in the transformation of the female body into an object, the most basic one being economic inequality. When one of the models tries to make a living by selling CDs with conversations for lonely people like her, she is laughed at by passersby, who advise her to get a modeling position that would bring her a better salary. These scenes show the participation of visual technology into a model of power sustained by gender inequality that turns female bodies into erotic objects. They portray the appropriation of the female body by the male gaze both in reality and in representation. The cameras held by the men who film women are extensions of their erotic perception that turn the female body into a nude. I want to highlight the problematic nature of eroticism turning to Laura Marks' definition of the erotic. She defines eroticism as "the ability to move between near and far, between control and 
relinquishing, being giver and receiver." ${ }^{\text {"T }}$ The erotic encounter takes the beloved "to the point where there is no distance from the body." ${ }^{\prime 6}$ The eroticism revealed by the film freezes the movement by not allowing the body to come again to its subjectivity. It reduces the body to its erotic properties, turning it into an object that must perform a male structuring of desire. The form of eroticism entailed by the male gaze opposes the eroticism associated with love. Besides the sexualization of the female body, the film also tackles the issue of eroticized violence, a problematic trait of pornographic representation. ${ }^{17}$

The key scene in the film is the climactic S/M scene arranged by Ankokuji, Nanami's patron. I will analyze more closely this scene because it is a scene of ritualized fantasy that transposes the filming men, Shun and spectators through the spectacle of eroticized violence. The S/M paraphernalia punctuates the mise-en-scene, including a bear skin where Ankokuji will swoon with pleasure after the climactic performance of two women almost strangling each other. The camera offers us multiple points of view, both partaking of the male gaze and reflecting on the male gaze. It is an eroticized scene that reproduces through visual means the sexual fascination of the men watching the performance. Close-ups of cameras taking pictures are edited together with long shots of the performance filmed by men, with framed shots of the performance itself and slow motion, hypnotic shots of sexualized violence. We gaze at what the men see, and we also see men in the act of gazing, a self-reflexive representation of the appropriation of the female body by male desire. The performance is shot in a surreal way accompanied by the soundtrack of a choir hymn alternating between stylized stills and slow motion hypnotic performance.

\footnotetext{
${ }^{15}$ Laura Marks, Touch (Minneapolis/London: University of Minnesota Press, 2002), xvi.

${ }^{16} \mathrm{Ibid}$.

${ }^{17}$ See Burns, Sexual Violence.
} 
Nanami plays the role of a little girl in a kimono, who is whipped and hurt by a Caucasian woman. Cries of pain in the soundtrack highlight the visual representation of violence against female bodies, while the close-ups and the slow motion shots transform the scene into a form of ecstasy. When the woman grips Nanami's head between her legs and Nanami's face contorts in pain, Ankokuji snatches the camera from one of the filming men, enraptured by the scene. Ironic interspersed shots show his beautiful wife and his child playing with him, revealing the double life of a family man and a voyeuristic sadist. Shun inadvertently witnesses the scene but close-up shots of his face reveal identifying pain rather than pleasure. His view represents the look, while Ankokuji's watching represents the gaze, the former guided by love and the latter underpinned by power. Shun's look perceives Nanami's body in its unity, as an object of desire and as a subject, while Ankokuji only sees her as object of desire. Even more than that, he projects his anger and pain onto the female body, experiencing women's pain as sexual pleasure. This discrepancy between the look and the gaze underscores the duality between love and power, between the recognition of women's alterity and their sexual objectification.

The clicks of the cameras accompany in a sound crescendo the climactic moment when Nanami leaves the woman unconscious. Women's pain is a ritualized performance designed for pleasure, a problematic expression of the appropriation of the female body, sexual not only in its nudity but also in pain. As Linda Williams shows, the female body "caught in the grip of intense sensation or emotion," offers spectators the most powerful sensations. ${ }^{18}$ She isolates the representation of pleasure in pornography, pain in horror genre and grief in melodrama but this $\mathrm{S} / \mathrm{M}$ scene turns pain into a representation of pleasure. It inscribes the male anger at women on the

\footnotetext{
${ }^{18}$ Linda Williams, "Film Bodies: Gender, Genre, and Excess," In Film Quarterly, 44, No 4 (1991): 2-
} 13,4 . 
female body through sexualized violence that women are paid to perform against each other for men's voyeuristic pleasure. ${ }^{19}$

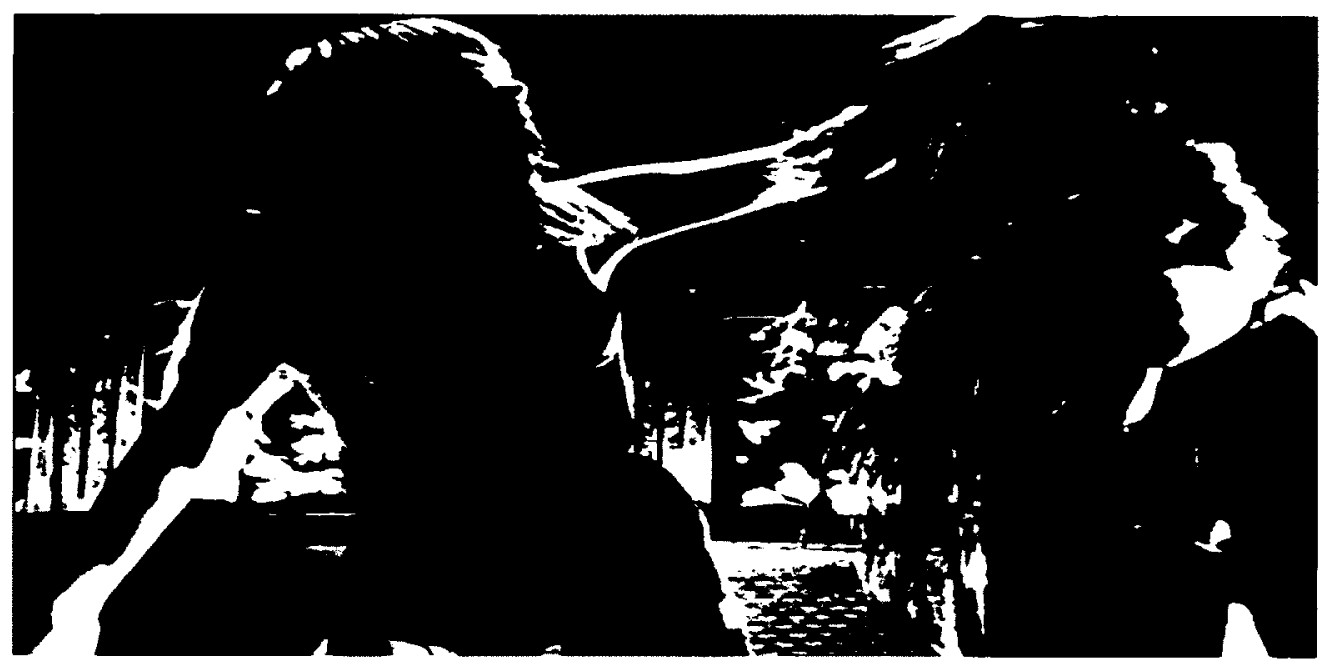

The underground $\mathrm{S} / \mathrm{M}$ scene shows the eroticization of female pain through the projection of male pain and anger upon the female body.

There is an inextricable duality between the self-reflexive, critical representation of the male gaze and a reenactement of it. Similar to the scenes showing the eroticization of the female body through the transformation of nakedness into nudity, the camera both exposes and reproduces the male gaze. It shows the body politics of inscribing the female body with eroticism, a consumerist model of desire supported by means of representation. The agency of women becomes possible through the economic exchange of their bodies and the appropriation of their pleasures and desires.

The camera captures three levels of nakedness: of the body in itself as marker of human, subjective presence, the body in the process of eroticization highlighted by the self-reflexive shots that show men capturing women's bodies with cameras, and the erotic body, the nude, in shots that extend or replace the men's vision. The camera

\footnotetext{
${ }^{19}$ The issue of eroticized violence pervades the whole genre of roman poruno developing in Japan in the 1960s and 1970s and it is also an important aspect of other New Wave figures such as Ōshima Nagisa.
} 
becomes a prosthetic eye that reproduces the male perception of the female body as erotic. At the same time, it also makes visible the mechanism of the male gaze and tries to look beyond the erotic potential of the female body in order to show how women live their bodies. Similar to Imamura, Hani's film reveals the duality of the cinematic medium as an instrument of male power over the female body and as an instrument for revealing the formation of female subjectivity through the body, both a technology of gaze and one of look. As Tsunoda shows, Hani dwelled extensively in his writings on the phenomenological relationship between the filmed object (taisho) and the director's subjectivity. "What Hani implies is that the "thing" the camera captures directly is not merely a material thing, but the thing that the filmmaker's subjectivity engages with..." ${ }^{20}$ In other words, Hani tries to recuperate in his filmmaking not the body as an object, but the body as a subject that the filmmaker engages with. The camera work in this film emphasizes the duality between looking and gazing, between capturing the subjectivity of the female body and the body as erotic object. The body is more than an object, it is the material representation of a subject engaged with the world and with others.

\section{Love and its Shadow}

Similar to the Eiko-Wada couple in Eros + Massacre, love starts for Nanami and Shun when their sexual encounter fails and instead they listen to each other's life story. Their bodies become meaningful for each other in terms of personal histories that take precedence over sexual desire. Both films stress this difference between sex and love as a difference between the film's visual dimension and its sound, between the male gaze and the exchange of voices that carry personal histories and open up the subjective potential of the female body. This infusion of the filmed body with subjectivity is also a mark of Hani's cinematic approach to the body. In his book,

\footnotetext{
${ }^{20}$ Tsunoda, Toward Human Experience," 6.
} 
Aesthetics of Camera and Microphone (Kamera to maiku no ronri, 1960) he has stressed the dialectic between filming as a human and filming as a documentarist, to which I would add filming as a male. ${ }^{21}$ Filming as a human involves an intersubjective relationship between the filmed subject/object that engages gender relationships of power, while filming as a documentarist strives to capture what the filmed subject/object really is. Hani believes in filming as a human, taking into account the intersubjective engagement of the director and the filmed persons (objects) in a mutual encounter. Filming as a male also takes into consideration the gendered differences in the construction of points of view. Cinematic means like subjective memory shots, counterpoint sound and voice over reveal to us as spectators the disciplining of the body by social norms and the oppressive objectification of the body. As in Imamura and Yoshida's case, I will refer to this stylistic approach as an ethical look that explores the construction of the object body, allowing for the presence of its alterity, its subjectivity. This idea is also applicable to Hani's use of non-professional actors, whose aural presence transcends the characters they are supposed to embody. This ethical approach to filmmaking enacts a negotiation of the power of the male director to objectify the female body through the acknowledgement of the subjectivity of the filmed object. At the narrative level of the film the ethical engagement with the Other is epitomized by the trope of love.

Love is the epitome of Lévinas' definition of ethics, as the openness to the infinite alterity of the Other, as a mutual flow between subjectivities governed by wonder and curiosity rather than by power. It is an ideal of freedom from power and traumatic memory through the opening of the boundaries of the self. However, it is also a fragile ideal constantly haunted by its shadow, power. I argued in the beginning

\footnotetext{
${ }^{21}$ Susumu Hani, Kamera to maiku no ronri [The Aesthetics of Camera and Microphone] (Tokyo: Iwanami, 1960), 81 .
} 
of this chapter that these two aspects are not opposed, since they are inevitably present in gender relationships although they exclude each other. They are both the signs of the body being caught in mechanisms of power and of the body's agency to resist power. Hani's effort to reveal women's alterity in sexual relationships becomes entangled in mechanisms of power inherent in the interaction between the cinematic apparatus and female bodies.

What is the relationship between love and sex, looking as mutual exchange and gazing as a form of containing and defining the Other as an object of desire? Hani focuses on two important transformations of sexual relationships taking place in the 1960s: the advent of romantic love as a modern trait of individual freedom, the liberation of sexuality and the commodification of the body in consumer society. While for Yoshida the enemies of sexual love were the gendered structure of the feudal family, the national state and the commodification of sex, in Hani's film Nanami's body is free from the family constraints that regulate sexuality through arranged marriages and to some extent she displays a free sexuality, which is nonetheless subsumed to technologies of the male gaze. As Mark McLelland has shown in his study, the postwar female liberation from the constraints of the feudal family and the ideology of motherhood turns into a system based on the consumption of desire. $^{22}$

Love appears to be the ideal of self-development and freedom from oppressive conditions because it is predicated on relationships that allow the unity of the sexual body with the self (subjectivity). The same idea appears in Eros + Massacre, which shows love as an ideal of individual freedom threatened by the power of social norms in the 1920s and by the commodification of the female body in 1960 s.

${ }^{22}$ See McLelland Love, Sex and Democracy in Japan during the American Occupation. 
The scene where the two adolescents visit Tokyo University is relevant for understanding the idealized mechanism of love that will be finally defeated by the commodification of the female body. I will analyze the film within the film scene of a student's love story viewed by Nanami and Shun. Hani self-reflexively analyzes the impact of film on the characters' engagement with the world. What Nornes ironically refers to as "puppy love" is the film made by an adolescent, a poetic and naive representation of the emotion of first love. ${ }^{23}$ The film alternates shots of the students' film footage with the projector and with the emotional reactions of spectators. Closeups of Nanami and Shun's faces show their fascination. They are moved and transformed by the ideal of love as an emotion that releases their affective potential from the grip of power, in Shun's case, his foster father's abuse and in Nanami's case, the alienation produced by the pornographic industry. As the film comes to an end, all spectators leave the room, except for Nanami and Shun, who are both glued to the screen and applaud profusely. This scene epitomizes Hani's view of cinema as a participatory process of interaction that is able to engage spectators at an ontological level.

The next scene shows a tracking shot of Nanami and Shun walking together accompanied by the soundtrack of a chorus of children, a sign of their return to innocence and unmediated emotions. As they walk, Shun is still in a dark mood and asks Nanami if she is still seeing "that weird guy, that adult." The "weird adult" symbolizes the appropriation of the female body through economic power and at the same time the perversion of the affective potential involved in the sexual body. Hani portrays these two male and female adolescents in order to critique the norms of power reinforced by the world of the adults, a view that echoes his approach to

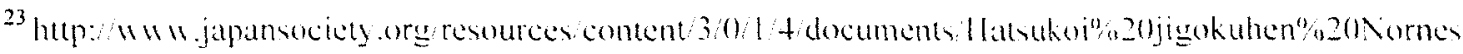
pdli, July 2012 
children." Every tentative form is, for children, an "experiment" (jikken) constantly seeking for a suitable one without stabilizing it." 24 The transformative "tentative forms" of children and adolescents is shaped by dominant forms of gender power that appropriate both Nanami's and Shun's bodies. This idea parallels the feminist theorization of the body as a source of transformative potential that destabilizes both the naturalization of sexuality and the self-identical form of subjectivity. Shun looks at Nanami with love, recognizing her subjectivity but his look of love is haunted by the male gaze. Mike Featherstone points out that the particularities of seeing the body we love. "Here the body gains a charge of affect which is not the cool surgical gaze measuring the body for cutting, but a seeing beyond, a seeing in motion, in process which points towards the body without image." 25 The body without image that he refers to is the living body marked by aura and affective, intense presence. Unlike Ankokuji who sees Nanami's body as an erotic image, Shun sees her body as a site of subjectivity. Although we see Nanami's body as image, the film also constructs her living body through the accumulation of details and interactions with the other characters, especially with Shun. The representation of love as an accumulation of knowledge about the Other counteracts her transformation into the sexualized image of the nude. However, similar to Shun, who perceives Nanami both as an eroticized object and as a subject, the medium of cinema constructs her as an erotic body while at the same time offering glimpses of her living, subjective body. In the following part I will analyze the film's representation of the constructed dimension of the body's sexual desire. I will use a riddle present as a leitmotif in the film, the story of cabbages and onions, as a metaphor for performativity.

\footnotetext{
${ }^{24}$ Tsunoda, "Toward Human Experience," 15.

${ }^{25}$ Mike Featherstone, "Body, Image and Affect in Consumer Culture," In Body and Society, No. 16 (2010): 193-221, 206.
} 


\section{Cabbages, Onions and Performativity}

Before meeting Nanami, Shun escapes the claustrophobic environment of his

home where he is abused by his stepfather, through his friendship with a little girl called Momi. The third scene in the film shows the two of them playing in a temple garden. Close-ups of their faces radiating innocence and freshness are edited together with tracking shots of them happily running and playing. A medium shot of them seated on stairs introduces Momi's riddle. "If you peel cabbages, their core will come out but what comes out when you peel onions?" He fails to answer the riddle, which appears again as a haunting voice over after the climactic hypnotic scene revealing his sexual trauma and the surreal scene of Nanami's S/M performance that Shun inadvertently witnesses. Both scenes reveal two forms of trauma. One is psychological and presented in images that his psychiatrist asks him to decipher from the mind screen while the other is an enactment of trauma through bodies of women in pain in $\mathrm{S} / \mathrm{M}$ performance. He poses the same riddle to Nanami when they have lunch together. The accompanying uplifting score by Takemitsu Tōru predicts a happy outcome. Nanami guesses the right answer and unlocks his traumatic imprisonment. "Why, if you peel onions, tears will come out." Their laugh cascades unstoppable and it is the first time in the film that shows Shun genuinely happy. The edited tracking shots of them running along the train tracks laughing emphasize the psychological and bodily liberation that allows Shun and Nanami to love and be happy. It also gives Shun the strength to resist his adoptive father's abuse.

I would like to analyze this riddle further, using Judith Butler's account of the illusory nature of the self as the core of the person, in other words, her theory of perfomativity. She has shown in many of her books that gender is not an effect of the body, nor is sexual desire the natural expression of the body's instinct but on the 
contrary, the accumulation of various forms of power that inscribe the body with gender and sexual norms. These social forms of power delete their presence, creating the illusion of a core of gender identity as a stable (heterosexual) category. "Acts, gestures and desire produce the effect of an internal core or substance, but produce this on the surface of the body through the play of signifying absences that suggest, but never reveal, the organizing principle of identity as a cause." ${ }^{26}$ The film peels away traumatic inscriptions of the body that reveal desire not as the flow coming from a stable core but as the result of sedimentation of various forms of disciplining the body.

Sex is for Shun an unconscious impulse to perpetuate the violence enacted on his own body as a defilement of innocence, while for Nanami sex is a profitable economic exchange of her body that offers her a place in society. The film's representation of these layers of experience that produce psychological effects and modes of subjectivity is a political analysis of the "constitution of the gendered subject and its fabricated notions about the ineffable interiority of its sex or of its true identity." 27 The words play with the riddle in the film is that once you start peeling away the strata constituting who Shun and Nanami are, only tears come out and no core. Similar to Imamura who searched for an essence of femininity, revealing instead various forms of power, Hani's film reveals sexuality as a transformation of innocent openness to the world into a disciplinary, traumatic form of desire that tends to reproduce itself. The traumatic experience comes from the inscription of innocent, presexual bodies with forms of sexual desire that turns them into objects of the Other's pleasure.

\footnotetext{
${ }^{26}$ Butler," Bodily Inscriptions, Performative Subversions," in The Judith Butler Reader, ed. Sara Salih (Malden MA: Blackwell Publishing, 2004), 110.

${ }_{27}^{2}$ Ibid.
} 
The moments Momi and Shun spend together are instances of plenitude and happiness before the creeping up of desire and Shun's public shaming. Here, Momi tells him the riddle of cabbages and onions.

The shot following Momi's riddle shows the ominous potential of trauma in the formation of desire. Momi wants to pee and he holds her body. The next shot shows a close-up of a reclining Buddha's serene face. The camera pans down to reveal the statue's almost imperceptible genitals. Shun holds her body and a close-up shows him caressing the girl's kimono. He closes his eyes and the next shot plunges us into his memories of his mother kissing him. The camera takes the place of his body and the kiss turns into a visual vertigo punctuated by ominous music. Memories of his childhood love and the traumatic break-up from his mother invade the safe space of happy friendship with Momi in the form of sexual desire. The Buddha's serenity is haunted by sexual desire. The borderline is transgressed but is immediately socially sanctioned. The camera reveals a man spying on them and he would later chase and beat Shun, socially shaming him. The chase is shot as Mark Nornes points out, in "extreme close-ups of the furious men that catch him and a long shot from above with the objective feeling of a surveillance camera." ${ }^{28}$ While surveillance has been denounced as a mechanism of social power, it is also one that creates safe channels for

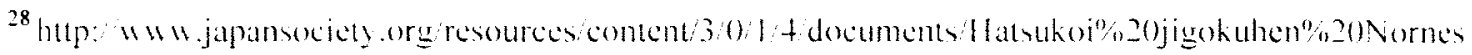
pdil, July 29.
} 
desire through interdiction. However, it is a mechanism that has failed Shun, who has been sexually abused by his father as a child, and it also fails Nanami by supporting the appropriation of her body. Desire is constructed by the double trauma of breaking up with the mother and child abuse, the only two forms of bodily affective exchanges known to Shun.

While it might be tempting to consider innocence as the core of the self, innocence precludes the formation of an enclosed self, being instead an open realm of possibility. Innocence means potential. David Desser suggests that Hani's focus on youth "is a focus on the moment when ambivalence is held in balance," in other words the realm of possibility inherent in youthful innocence is given shape by dominating norms of power. ${ }^{29}$ There is no core of sexual identity for Nanami and Shun, since their actions and desires are haunted by inscriptions of their bodies by the power of male desire. While Shun's appropriation of his bodily potential for desire and sexual pleasure is an anomaly bordering on pathology, Nanami's experience shows this appropriation as a social institution where the old system of prostitution merges with the modern institution of pornography. The film goes further in describing not only the objectification of the female body but also the eroticization of violence. In the following part I will analyze the representation of trauma and its relationship with the gendered body. The eroticization of violence against the female body is treated in the film as a displacement of male psychological trauma onto female bodies.

\section{Male Trauma and the Wounds on the Female Body}

Hani explores the ability of the cinematic medium to render affective, unconscious states through images and sound. The film shows the transformation of implicit memory into explicit memory by making us see together with Shun the screen

${ }^{29}$ Desser, Eros + Massacre, 63. 
of his traumatic experience. The mark of this experience has been the visible effect on his body of his impotence and his momentary desire for Momi, which is made visible in the hypnotic representation of unconscious images. Traumatic sexual experience shapes sexual desire. Shun's sexual trauma is paralleled by Ankokuji's predatory sexual desire inflamed by the wounds on Nanami's body. The fantasy of erotic violence is explained in the film as a result of a displacement of male anger and pain onto the female body.

I will analyze the scene where Shun is hypnotized by a psychiatrist, a scene that blurs the differences between cinema as a medium and individual memories. Memories are seen as a film, while film produces memories, engaging the viewers in an ontological relationship. After the episode of public shaming, his foster mother takes him to the doctor, who urges him to do "image rehearsal" in hypnosis. The camera alternates between long takes of Shun's body and embodied representations of his point of view. The surreal visual effects of smoke and the sound effects of water suggest the entry into a forbidden territory. Shun is urged to speak about the images seen on a screen and the film makes visually available to us as spectators what is unseen by the doctor (only heard) and only unconsciously seen by Shun. It creates images that are impossible to represent in reality other than through words, because they belong to the unconscious mind. The image on the memory screen is blurry suggesting the impossible recuperation of coherent memories. The first shot is of flying pigeons, followed by the temple garden and Momi. These are images of freedom, innocence and happiness, interrupted by a man peeking and the shouts of angry men that call him "lecherous." He tells the doctor what he sees, translating the images into words. Blurry images of shadows are edited with clear images of his foster father who approaches him as a child, telling him that his wife has gone out. At 
this point, we return to a close-up of his body twitching and refusing to see. "I am afraid, I don't want to see."

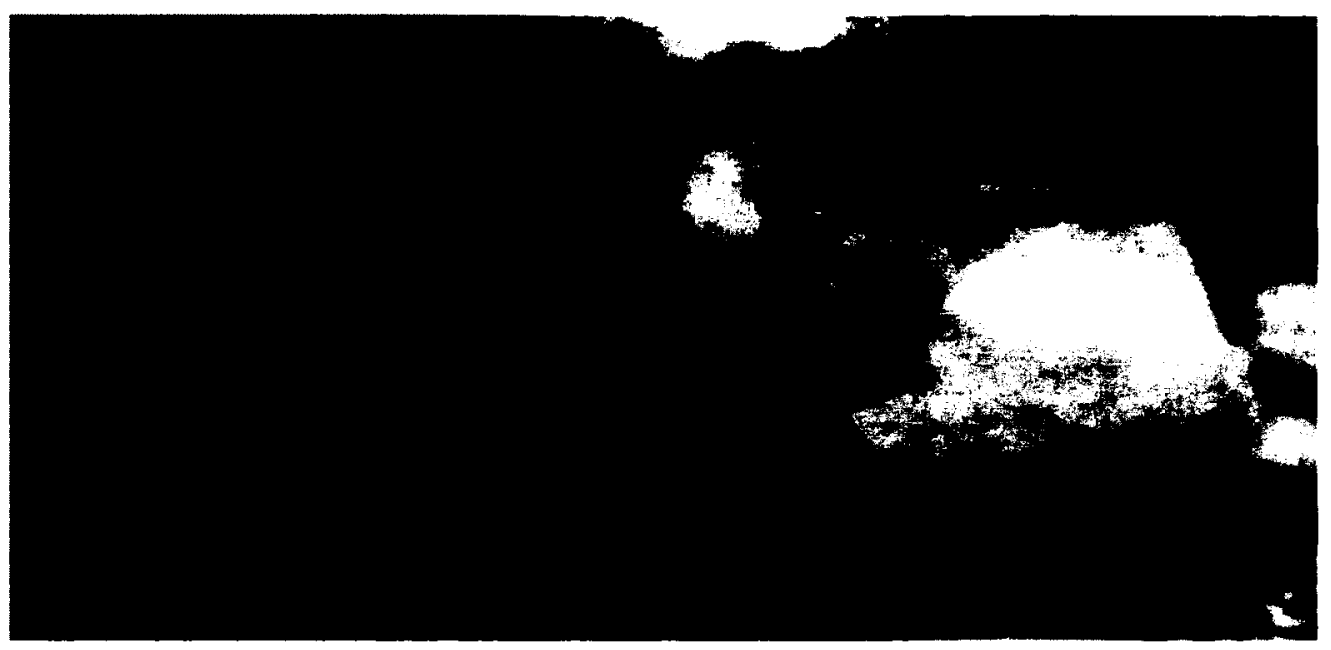

The memory screen shows blurry images of Momi, followed by a dead pigeon, symbols of the loss of innocence. This is the image of Shun's face as a boy preceding the traumatic event.

His refusal to see is followed by an image of his foster mother over the screen of his memory. She is also scared and we soon hear screams. "Stop it, Please stop it." Her screams are associated with the sound of his crying. Images are as hurtful as the experience itself, raising questions about the ways in which the film mediates pain, and the ontological implications of viewing. Trauma is also revealed earlier in the film through the sound effect of metal carving in the first scene of the encounter between Shun and Nanami. That sound operates as a counterpoint to the images suggesting nevertheless an ominous relationship between them. Shun's sexual encounter is haunted by his trauma.

If trauma is at its most basic definition an invasion of the self by an external force, a literal inscription of the body, Nanami's transformation of youthful innocence into a body performing $\mathrm{S} / \mathrm{M}$ scenarios as a literal inscription of her body with male desire is not far from traumatic experience. The wounds on her body are a source of pleasure for the patron who pays for her performances. While only indirectly related 
to trauma, the film explores representation of pain as ritualized performances of $\mathrm{S} / \mathrm{M}$ scenes. Nanami's patron, Ankokuji takes her down to a cellar where women are dressed up and fight each other. If the female body has been appropriated by male desire and has been subjected to the power of the male gaze, what issues are raised when the source of pleasure is not the nude female body but performed (or real) pain? Ankokuji reveals an answer to this question. In a later scene, Shun stops him and asks about Nanami. "Do you see dreams of fire? You don't, because you are a soft (amai) person. I cannot trust women, but I am attracted by Nanami's kindness. My wife is made of ice, I could set fire to her one day." An ironic insert shot shows close-ups of his wedding ring and the face of his beautiful wife. "I am fascinated by Nanami's wounds. Her wounds were made for me." The patron's duality reveals the duality inherent in the discrepancy between socially accepted forms of desire and dangerous fantasies, between love and power. Male pain is displaced onto the female body that becomes the bearer not only of desire but also of pain. I agree here with Linda Williams that we need to see pornography as a form of "cultural problem solving" but one that cannot be analyzed without a theory of power. ${ }^{30}$

Theorists of trauma define it as a shattering of identity, a destruction of the symbolic order in which people make sense of their lives. ${ }^{31}$ Ruth Leys, a famous theorist of trauma identifies two methods of approaching trauma, the mimetic and anti-mimetic one. Mimesis in the case of trauma implies a hypnotic identification with a traumatic situation that leads victims to repeat and imitate the traumatic event

\footnotetext{
${ }^{30}$ Williams, "Film Bodies: Gender, Genre, and Excess," 12.

${ }^{31}$ See Kaplan, Trauma Culture the Politics of Terror and Loss in Media and Literature (New Brunswick: Rutgers University Press (New Brunswick: Rutgers University Press, 2005).
} 
without remembering it. ${ }^{32}$ However, this approach precludes individual autonomy and agency, which led to the antimimetic theory according to which the subject is aloof from experience and has the possibility to remember. This theoretical difference underpins the difference between "implicit memory [which] involves sensory images, body sensations, emotions and automatic behaviors. Explicit memory involves facts, sequence and meaning." ${ }^{33}$ The task of the psychiatrist in the film and the task of the film for us as spectators is to turn implicit memories into explicit memories explaining the formation of sexuality through the appropriation of the adolescent body by invading desire.

I have shown in this part how trauma inscribes the body constructing forms of sexual desire that preclude individual agency and subjective participation in sexual encounters. Trauma deletes its sources by transforming into implicit memory that guides actions and desires, which tend to reproduce the traumatic experience. The film makes visible forms of memory that are unseen even by the subject who has them, making us participate in unconscious representations. It also self-reflexively reveals the visual fascination with female pain and subjection that turns male unconscious fantasies into a system of representation. The eroticization of the violence performed on Nanami's body is a result of a displacement of male pain and anger on the female body. This desire turns into a mode of representation self-reflexively portrayed by the film but also reenacted in the film's representation.

\section{Conclusion}

Hani's film emphasizes the binary between the look and the gaze, love and power, the body in itself and the body on display, which exclude each other but can

\footnotetext{
32 Ruth Leys, Trauma. A Genealogy (The University of Chicago Press: Chicago and London, 2000), 298.

${ }^{33}$ See Babette Rothschild, The Body Remembers (New York: W.W. Norton \& Company, 2000), 68-69.
} 
nevertheless coexist in the same person and in the same mode of representation. I argued that the film shows the appropriation of the sexual and affective potential of the adolescent body, revealing the constructed nature of sexual desire. The appropriation of bodies produces specific forms of sexual desires revealed in the film through scenes of the unconscious mind. The film problematizes the duality between the body as subject and the body as object inherent in sexual relationships and in modes of viewing. The gaze represents the body as object while the look searches for the body as subject. The film represents self-reflexively the production of female erotic bodies/nudes through the power of the male gaze, problematizing the advent of pornography in the Japanese media in the 1960s. Even more than that, it also shows the eroticization of pain and violence against the female body. The end of the film is relevant for Hani's pessimistic position on the ethical possibilities of gendered relationships. Shun is chased by a group of men participating in the shooting of S/M performance. They want him to persuade Nanami to work again as a model for S/M performance and running from them, Shun is killed by a car. The last shots of the film show a long take of Nanami's face at the window accompanied by a melancholy soundtrack. This ending shows the crushing of hope in love as a form of subjective freedom and Nanami's full cooptation by the pornography industry. The female body is subjected to the commodification of desire, a new form of gender power emerging in Japan in the 1960 s that undercuts the ideals of female liberation and love as a mutually enriching exchange. The film constructs the narrative duality between love and power represented through the visual duality of the look and the gaze. This is the premise I sustained throughout this dissertation: the possibility of an ethical, mutual engagement of men and women in sexual relationships (through a recognition of the female as both an object and a subject) and the subjective engagement of directors 
with the objects/subjects they filmed. The end of the film suggests the demise of the look in cinematic representation. 


\section{Conclusion}

The purpose of this dissertation was to analyze the politics of representing female bodies in the New Wave Japanese cinema. Focusing on Imamura Shōhei, Yoshida Kiju and Hani Susumu, I argued that their films about women reveal the struggle between female subjectivity and the objectification of the female body both by feudal and modern institutions. The cinematic representation of the female body in these films performs a negotiation of the power of the male gaze through the ethical look as a form of understanding the alterity of women and of acknowledging their subjectivity. I situated these three filmmakers against the trend of the cinema in the 1960s that moved towards the sexual objectification of the female body, celebrating consumerism and the (male) sexual liberation.

Imamura, Yoshida and Hani describe the process of filmmaking as an ethical encounter that produces intersubjective transformation. Their self-reflexive critique of heteropatriarchal institutions that subordinate women such as the feudal family, the rural system of female exchange, prostitution, gender inequality and cinematic representation comes close to an ethical (we could even say feminist) stance that explores the construction of femininity through the disciplining of the female body. The films show how the social status of women is predicated upon the uses of their bodies. All three directors expose the power inherent in gender relations and cinematic representation by analyzing the interplay between the female body as the material manifestation of subjectivity and as an object of vision and desire. The films I analyzed in this dissertation make visible gender politics in the Japanese postwar society. They explore the cultural construction of female bodies politicizing sexuality and the institution of cinema that both participates into and critiques the 
objectification of the female body.

I explored here the confluence of two tendencies noticeable in the preoccupation of New Wave filmmakers. The first one is the self-reflexive portrayal of sexuality not only as an expression of bodily pleasure but also as a struggle against repressive ideological forces of society. The other tendency is the exploration of sexuality both from a male point of view and from a female point of view. As I stated in the introduction, the discourse of the liberation of the body in postwar Japan has been mainly a male discourse. Although political and sexual repression was an urgent issue for most of the filmmakers in this period, Imamura, Yoshida and Hani focus on what that repression meant for women, rather than men. The strategy of politicizing female bodies and opening up a space for a female perspective is ultimately an ethical engagement involving respect for the alterity of women. My analysis brought into dialogue a phenomenological perspective that analyzes bodies as complex systems divided between subjects and objects, with an analysis of power that shows the objectification of female bodies.

Rather than being concerned with the visual, material surfaces of the body, this dissertation explored the in-betweenness of bodies, the capacity to act on and be acted upon. The approach to bodies as interfaces between external norms and internal selves made possible the analysis of the affective dimensions implicated in women's bodily experiences. Imamura's films reveal female resilience and survival performed through pain, anger and acts of cruelty. I followed in Yoshida's film the relationship between sexual love and freedom as individual self-realization and pleasure. In my consideration of Hani's film I highlighted the interplay between trauma, love and power, where love is represented as the means to defy objectification through the integration of the body as subject in sexual interactions. 
I attempted to demonstrate in this analysis that the crisis of subjectivity in postwar Japan generated ethical possibilities of filmmaking that negotiated the gender power inherent in cinematic representation. I paid close attention to the minute accumulation of details in mise-en-scene, camera position, acting, voice and editing that revealed the relationship between historical transformation and the transformation of bodies and subjectivities. Many film critics noted the self-reflexivity and the political dimension of the New Wave films. This dissertation is an inquiry into the gendered aspect of filmmaking as a relationship between male directors and represented female bodies. Self-reflexivity makes visible the power inherent in the cinematic medium to participate in the objectification of the female body but also its potential for self-criticism. Self-reflexivity implies not only the scrutiny of one's subjectivity but also the opening of the subject to the alterity of the Other. It is directly observable in the visual style of the films that foreground the presence of cameras and critique the power of the male gaze. Both in their visual style and in their writings about their films, Imamura, Yoshida and Hani self-reflexively negotiate their social and institutional positions of authority as male directors in their relationship with the actresses they employ and with the female characters they represent. Their ethical position involves an encounter with the alterity of women that disrupts the filmmaker's illusory position of omnipotence or the power of the gaze. The representation of the female body involves desire and responsibility, a duality inherent in their films as the interlacing of the gaze with the look.

Yomota hopes that researchers can discover an "aesthetic unconscious" that connects filmmakers in this period despite their ostensible differences.' I hope this

\footnotetext{
'Yomota, "The Genealogy of the Mother," 51.
} 
dissertation shows an aspect of this aesthetic unconscious manifested in filmmaking as a self-reflexive negotiation of gender power that acknowledges the ethical problems raised by the male gaze and critiques Japan's heteropatriarchal institutions. This dissertation aims to enrich previous studies of the Japanese New Wave cinema through the analysis of gender, sexuality and power both in the narrative of the films and in their visual aesthetic. In terms of content these films deal with themes reflecting the preoccupation with desire, subjectivity and the fracture points in the Japanese identity. The argument I built in this dissertation was that that these films analyze the cultural dimensions of eroticism and sexuality in the construction of female bodies exposing the formation of femininity through the disciplining of the female body.

Imamura, Yoshida and Hani produced representations of gendered body politics at three social levels: low class, rural women, intellectual elites and working class people in the city. Imamura's fiction films and documentaries focus on low class or low caste women, showing the multiple intersecting technologies of power that discipline the female body creating forms of subjectivity that adapt to adverse circumstances. The rural poverty and the system of female exchange, the urban alienating capitalist system and the patriarchal family marginalize low class women who can survive through prostitution. They learn to use their bodies as material objects and they objectify other women, participating into the power of patriarchy. Prostitution and rape are in Imamura's fiction films rituals of violence against the female bodies aiming to produce docile subjects, but which produce instead angry rebellion directed mostly against other women. Imamura's aim in his films was to portray female resilience and strength against intersecting and overlapping forms of oppression impossible to overcome. Insect Woman and Intentions of Murder show 
how the institutions of the feudal family, the female exchange in the rural context and gender inequality sustain prostitution and rape as two systems that discipline female bodies and subjectivities making them willing participants into systems that dehumanize them. Imamura integrates and validates women's bodily and emotional experiences in the official discourse, authenticating their cinematic representation through realist techniques. I argued that he used the camera as an anthropological tool for grasping women's relationships to their environments, a strategy that reveals the construction of femininity as a form of disciplining the female body. The anthropological impulse is also one of documenting the experiences of people at the bottom levels of society. I read the interactions of the female bodies with the social spaces around them as modes of orientation in the world structured by affective responses to violence. I critiqued Imamura's anthropological approach for its allegiance to the power of disinterested, objective observation epitomized in the metaphor of entomology. The merit of this approach is that of revealing the contextual cultural constraints of becoming a woman both in the Japanese rural and in the urban context and thus portraying (maybe against Imamura's own beliefs) not women's unchanging nature but the intersection of historical oppressive forces that discipline female bodies.

Imamura's two documentaries about women represent the points of convergence and conflict between women's memories of personal experiences and Japan's official history while problematizing the documentary's role in the formulation of an ethics of filmmaking. They use the voices of women and their bodily experiences to counteract the homogenous national discourse, to critique the concept of historical truth and to reveal the placement of the female body as the sexual boundary of the nation. I argued that The History of Postwar Japan as Told by a Bar 
Hostess performs the critique of the nation by focusing on marginalized women who transgressed its boundaries. The politics of alliance between Japan and U.S. is paralleled at a bodily level by the sexual relationships between a Japanese woman and American GIs. Karayuki-san, The Making of a Prostitute revealed the transformation of the female body into an object beyond national boundaries but still highly dependent on Japan's transnational politics of expansion in Asia. In my analysis of the film I showed how Zendō's body is marked by class and gender exclusion, epitomized by the abjection of overseas prostitutes. The presence of conflicting views, the contrast between image and voice, between events and women's memories, nation and female bodies produces in the two documentaries a critique of truth as perspectival and contingent and a representation of female embodied history close to the feminist construction of women's oral histories. Similar to Imamura's fiction films, these two documentaries follow the life history of individuals, showing their embodiment of national history. At the level of visual style, the embodied presence of the director brings together the structure of the face-to-face interview with the distancing presence of the camera, successfully combining the gaze as a form of power and the look as mutual negotiation. This negotiation is also present in the focus of the films on the sound of women's voices as testimonies of personal experiences, performing a critique of the predominance of the visual as part of the national discourse. The documentaries try to integrate women's bodily experience into a discourse that has marginalized and trivialized them. Imamura's strategies of creating a discourse for marginalized women and of exploring the body in relationship with its environment can be critically called feminist because they reveal the construction of femininity through norms that discipline female bodies. 
Yoshida's film, Eros + Massacre filters his present time of the 1960s through the creation of time images that represent the existential struggles of Japanese intellectuals in the 1920, more specifically, the anarchist Ōsugi Sakae and the feminist Itō Noe. Similar to Imamura, he explores the formation of subjectivity through norms of power that inscribe bodies. However, unlike Imamura's representation of women's survival and resilience in abusive systems, Yoshida explores love and sexual relationships as means of individual freedom and self-realization both for men and for women. Rather than focusing on institutions that discipline female bodies, his film portray the struggle of individuals for self-realization through sexual and emotional freedom. The representation of intellectual and existential problems shifts the weight from the analysis of sexual objectification to the analysis of love and institutional forms of power that appropriate it for other purposes than individual freedom and happiness. Yoshida indicts his generation for the commodification of desire that creates an alienating form of sexual freedom devoid of mutuality and affect. My analysis of Yoshida's film in conjunction with his theoretical work focused on his discourse of individual subjectivity as an open, transformative engagement with the world, a stance visible both in his filmmaking practice and in the content of his film.

The film constructs time from the subjective perspective of a female character as time images or as duration, where past, present and future coexist. Through editing it creates time images that bring the past into the present through the mediation of a character's subjectivity. Through mise-en-scene the film creates duration revealing love and passion as a means of defying the temporal transience of the material body. Resurrecting the historical figures of the anarchist Ōsugi Sakae and feminist Itō Noe, the film addresses the alienation felt by the youth in the $1960 \mathrm{~s}$, when new forms of power emerge, one of them being the commodification of desire. The film's 
comparison of two time periods highlights the historicity of bodies and sexual relationships and it presents love as a form of mutual negotiation between bodies and subjectivities haunted by gender power. This negotiation is also replicated in his filmmaking strategies. I argued that Yoshida dismantles the scopic regime of cinema that turns women into performing objects dutifully reflecting the director's vision. In its place we have a transformative negotiation where Okada articulates Yoshida's subjectivity and her own presence while Yoshida is himself changing his subjective position under Okada's presence. This stance allows for an exchange of gazes that defies the power of the male gaze to contain and define women. Through his phenomenological view of filmmaking as a transformative engagement of the self with the Other, Yoshida negotiates his power position as a male filmmaker and he offers in his film a thorough exploration of the cultural, historical placement of the body, revealing how even the most intimate aspects of personal life are political.

Hani Susumu's film, Nanami, The Inferno of First Love represents the psychological construction of sexuality and desire for working class youth. It explores a set of dichotomies between love and power, innocence and exploitation, the look and the gaze. Although these binaries exclude each other, they coexist at the level of the psyche and they are both present in the cinematic medium. Similar to Yoshida's case, filmmaking is for Hani a transformative subjective encounter and a means of self-discovery. The representation of unconscious affective states in his films highlights tbe fluidity of the self, permanently open to transformation and vulnerable to power. I argued that the film's focus on the psychological struggles of the adolescent body showed the construction of desire through social constraints and traumatic experiences. In this film power is envisioned as the supremacy of male desire supported both by the social system pervaded by gender inequality and by 
systems of representation that produce erotic bodies. This power affects both women and children through the alienation of their bodies from the potential of innocence and self-expression. Resistance to power takes the form of love as an opening of the self to the wonder at the alterity of another person, a liberating form of ethics. In my analysis of the film I focused on the self-reflexive strategies that showed the inscription of the female body with eroticism, the transformation of nakedness into nudity, problematizing the advent of pornography in the Japanese media in the 1960s. Even more than the eroticization of the female bodies, the film also shows the eroticization of pain and violence through the projection of male trauma and anger onto the female body. Through its representation of the unconscious as a bodily inscription by external events, Hani's film reveals the performativity of desire and sexual behavior. However, Nanami, The Inferno of First Love does not perform the same institutional critique performed by Imamura and Yoshida's films. It might be argued that its politicization of sexuality and the body are less radical because of the restricted focus on psychology and affective relationships. The film both critiques and reproduces the appropriation of the female body through the male gaze, which explains the controversies surrounding its borderline status as art film and exploitation. With this proviso in mind, I argued that the film envisioned forms of sexuality that are not based on power but on mutual engagement. Sexual love transcends the objectification of the female body through the integration of the body as subject and object. The film shows the possibility of mutual forms of desire and pleasure for men and women as the result of an effective engagement with one's traumatic past.

This dissertation aimed to reveal an analysis of gender power enacted both by the institution of cinema and by other socio-historical institutions in postwar Japan. 
This power appropriates the female body for its social uses producing women's alienation from their bodies as sources of pleasure and self-realization.

I demonstrated that Imamura, Yoshida and Hani created a cinematic style based on intersubjective negotiation that revealed the duality between the look and the gaze. The second argument I followed throughout my dissertation is that these films politicize the female body revealing the struggle between female subjectivities and the institutional disciplining of their bodies. My argument showed Imamura, Yoshida and Hani's engagement with the alterity of women through two strategies: the exploration of the historical construction of femininity and the self-reflexive acknowledgement of the gender power governing cinematic representation.

I argued that the films analyzed in this dissertation form a different category among the films in the 1960 s that participate in the visual commodification of female bodies. Both in their style and their vision they invite reflection and awareness of the multiple ways female bodies are objectified in their contemporary world. Rather than exploiting the financial success of representing desire and sexuality in films from a male point of view, Imamura, Yoshida and Hani show these aspects from women's points of view. If for bell hooks the experience of cinema entails a "pulling away from the familiar and journeying into and beyond the world of the Other...," I argue that these films invite us to an unfamiliar journey into women's embodied experiences. ${ }^{2}$ The points of view of farmers or of rebelling students duly received their share of cinematic representation but few films in the 1960s offered a politicized view of women and their struggles. In a context where the Japanese mass media in the $1960 \mathrm{~s}$ was moving towards the visual objectification of the female body, I see these films as question marks and moments of reflection on that transformation.

\footnotetext{
${ }^{2}$ hooks, Feminist Theory: From Margin to Center (Cambridge: South End Press, 2000), 2.
} 


\section{Bibliography}

Ahmed, Sara. Queer Phenomenology, Orientations, Objects, Others, Durham: Duke University Press Books, 2006.

--.. ed. Transformations: Thinking Through Feminism, New York: Routledge, 2000.

Arima, Tatsuo. The Failure of Freedom: A Portrait of Modern Japanese Intellectuals, Cambridge, Mass.: Harvard University Press, 1969.

Bardsley, Jan. The Bluestockings of Japan: Feminist Fiction and Essays from Seitō, 1911-1916, Michigan: Center for Japanese Studies, The University of Michigan, 2007.

Bazin, André. What is Cinema? Vol II, Trans. Hugh Gray, Berkeley: University of California Press, 1971.

---."The Myth of Total Cinema," In Film Theory and Criticism: Introductory Readings, eds. Leo Braudy and Marshall Cohen, New York and Oxford: Oxford University Press, 1999, 170-174.

--.."The Ontology of the Cinematic Image," In Film Theory and Criticism: Introductory Readings, eds. Leo Braudy and Marshall Cohen, New York and Oxford: Oxford University Press, 1999, 166-170.

Benjamin, Walter. "The Work of Art in the Age of Mechanical Reproduction," In Illuminations, ed. Hannah Arendt, Trans. Harry Zohn, New York: Harcourt, Brace and World, 1968, 217-251.

Berger, John. "Ways of Seeing," In The Feminism and Visual Culture Reader, ed. Amelia Jones, London and New York: Routledge, 2003, 37-40.

Bock, Audie. Japanese Film Directors, New York: Kodansha International, 1978.

Bordo, Susan. "Feminism, Foucault and the Politics of the Body," In Feminist Theory and the Body. eds. Janet Price and Margrit Shildrick, New York: Routledge, 1999, 246-258.

---. Unbearable Weight: Feminism, Western Culture, and the Body, Berkeley: University of California Press, 1993.

Bourke, Joanna. Rape, London: Virago Press, 2007.

Burns, Catherine. Sexual Violence and the Law in Japan, London: Routledge Curzon, 2005.

Butler, Judith. Bodies That Matter: On the Discursive Limits of Sex, New York: Routledge, 1993. 
-... "Contingent Foundations: Feminism and the Question of 'Postmodernism," In Feminists Theorize the Political, eds. Judith Butler and Joan W. Scott, New York: Routledge, 1992.

--.. Undoing Gender, New York: Routledge, 2004.

Davis, Kathy. "Embody-ing Theory: Beyond Modernist and Postmodernist Readings of the Body," In Embodied Practices, Feminist Perspectives on the Body, New York: Sage publications, 1997, 1-27.

Deleuze, Gilles. Cinema 2-The Time Image, Trans. Hugh Tomlison and Robert Galetta, New York: Continuum International Publishing Group, 2005.

Desser, David. Eros Plus Massacre. Indianapolis: Indiana University Press, 1988.

Doane, Anne Mary. "Woman's Stake: Filming the Female Body," In Feminism and Film Theory, ed. Constance Penley, New York: Routledge, 1988. 216-228.

Downing, Lisa and Saxton, Libby. Film and Ethics, Foreclosed Encounters, New York: Routledge, 2010.

Elsaesser, Thomas. Film Theory; An Introduction Through the Senses, New York, Routledge, 2010.

Featherstone, Mike. "Body, Image and Affect in Consumer Culture," In Body and Society, No 16 (2010): 193-221.

Foucault, Michel. History of Sexuality, Trans. Robert Hurley, vol. 1, 2, 3. New York: Vintage, 1990. First edition, 1977.

---. Discipline and Punish: The Birth of the Prison, Trans. Alan Sheridan. New York: Vintage, 1995.

Fujime, Yuki. Sei no rekishigaku [The History of Sexuality], Tokyo: Fuji shuppan, 1997.

-... "Japanese Feminism and Commercialized Sex," In Social Science Japan Journal, Vol. 9, No. 1 (2006): 33-50

Fujiwara, Chris. "Interview with Yoshida Kiju," In Yoshida Kiju-50 Years of AvantGarde Filmmaking, ed. Dick Stegewerns, Oslo: Norwegian Film Institute, 2010.

Gatens, Moira. Imaginary Bodies: Ethics, Power, and Corporeality, London: Routledge, 1996.

Gluck, Carol. "The "End" of Postwar: Japan at the Turn of Millennium." In Public Culture, 10, No. 1 (1997): 1-23. 
Grosz, Elisabeth. Volatile Bodies. Toward a Corporeal Feminism, Bloomington: Indiana University Press, 1994.

Hani, Susumu. Kamera to maiku no ronri [The Aesthetics of Camera and Microphone], Tokyo: Iwanami, 1960.

hooks, bell. Feminist Theory: From Margin to Center, Cambridge: South End Press, 2000.

---. Reel to Real, New York: Routledge, 1996.

Igarashi, Yoshikuni. Bodies of Memory: Narratives of War in Postwar Japanese Culture, New Jersey: Princeton, University Press, 2000.

Iles, Timothy. The Crisis of Identity in Contemporary Japanese Film, Boston: Brill, 2008.

Imamura, Shōhei. Eiga wa kyōki no tabi de aru: watashi no rekishi-sho. [Film is a Journey into Madness, A Personal History], Tokyo: Nihon keisai shinbun-sha, 2004.

---. Imamura Shōhei no eiga, zensakuhin no kiroku [Record of Imamura Shōhei's Films], Tokyo: Haga shōten, 1971.

Imamura, Taihei. "A Theory of Film Documentary," Trans. Michael Baskett, In Decentering Theory: Reconsidering the History of Japanese Film Theory, Review of Japanese Culture and Society, Tokyo: Josai University Press, (December 2010): 52-59.

Jones, Amelia. Ed. The Feminism and Visual Culture Reader, London: Routledge, 2003.

Jung, Carl Gustav. On the Psychology of the Unconscious, Trans. Beatrice M. Hinkle, New York: Dover Publications, 2003. First edition, 1917.

Kaplan, E. Ann. Looking for the Other: Feminism, Film, and the Imperial Gaze. New York: Routledge, 1997.

Katori, Shunsuke. Imamura Shōhei densetsu [The Legend of Imamura Shöhei], Tokyo: Kawade shobo shinsha, 2004.

Kehr, Dave. "The Last Rising Sun," In Film Comment, 19, No. 5 (Sep/Oct 1983): 3240.

Koikari, Mire. "Rethinking Gender and Power in the US Occupation of Japan, 19451952," In Gender \& History, Volume 11, No 2, (July 1999): 313-335.

Koschmann, J. Victor. Revolution and Subjectivity in Postwar Japan, Chicago: The University of Chicago Press, 1996.

Lee Bartky, Sandra. "Foucault, Femininity and the Modernization of Patriarchal Power," In_Writing on the Body: Female Embodiment and Feminist Theory, eds. Katie Conboy, Nadia Medina, and Sarah Stanbury. New York: Columbia 
University Press, 1997, 129-155.

Lévinas, Emmanuel. Humanism of the Other, Trans. Nidra Poller, Chicago: University of Illinois Press, 2003.

Leys, Ruth. Trauma. A Genealogy, The University of Chicago Press: Chicago and London, 2000.

MacDonald, Keiko. Cinema East A Critical Study of Major Japanese Films, London and Toronto: Associated University Presses, 1983.

---. Reading a Japanese Film: Cinema in Context, University of Hawaii Press, 2006.

Mackie, Vera. Feminism in Modern Japan, Cambridge: Cambridge University Press, 2003.

MacKinnon, Catharine. Sexual Harassment of Working Women-A Case of Sexual Discrimination, New Haven: Yale University Press, 1979.

Marks, Laura. Touch, Minneapolis/London: University of Minnesota Press, 2002.

McLelland, Mark. Love, Sex and Democracy in Japan during the American Occupation. New York: Palgrave Macmillan, 2012.

Mellen, Joan. The Waves at Genji's Door-Japan Through its Cinema, New York: Pantheon Books, 1976.

Mihalopoulos, Bill. "Becoming Insects: Imamura Shōhei and the Entomology of Modernity," In The Power of Memory in Modern Japan, eds. Sven Saaler and Wolfgang Schwentker, Boston: Brill/Global Oriental, 2008, 277-290.

---. Sex in Japan's Globalization, 1870-1930, London: Pickering and Chatto, 2011.

Mulvey, Laura. Visual and Other Pleasures, Bloomington: Indiana University Press, 1989.

---. "Visual Pleasure and Narrative Cinema," In Screen 16, No. 3 (1975): 6-18.

Nakata, Toichi. Shōhei Imamura Interview," In Shōhei Imamura, ed. James Quandt, Toronto: Toronto International Film Festival Group, 1997, 107-125.

Nichols, Bill. Representing Reality: Issues and Concepts in Documentary, Bloomington and Indianapolis: Indiana University Press, 1991.

-.-. "The Voice of Documentary," In Film Quarterly, Vol. 36, No. 3 (Spring, 1983): 17-30.

Nornes, Abe Mark. Forest of Pressure, Ogawa Shinsuke and Postwar Japanese 
Documentary, London and Minneapolis: University of Minnesota Press, 2007.

---. "The Postwar Documentary Trace: Groping in the Dark," In Positions, Vol. 10, No. 1 (Spring 2002): 39-78.

Noonan, Patrick. "The Alterity of Cinema: Subjectivity, Self-Negation and SelfRealization in Yoshida Kiju's Film Criticism," In Decentering Theory: Reconsidering the History of Japanese Film Theory, Review of Japanese Culture and Society, Tokyo: Josai University Press, (December 2010): 110129.

Okada, Mariko. Joyū Okada Mariko [The Actress Okada Mariko], Tokyo: Bunshun, 2012.

Ōshima, Nagisa. Cinema, Censorship and the State: The Writings of Nagisa Ōshima, 1956-1978, Trans. Dawn Lawson, Cambridge: MIT Press, 1992.

Pateman, Carole. The Sexual Contract, Berkeley: Stanford University Press, 1988.

Pettman, Jan Jindi. "Boundary Politics: Women, Nationalism and Danger," In New Frontiers In Women's Studies: Knowledge, Identity And Nationalism, eds. Mary Maynard and June Purvis, London: Taylor and Francis e-Library, 2005, 187-203.

Phillips, Alastair and Stringer, Julian. eds. Japanese Cinema: Texts and Contexts, New York: Routledge, 2007.

Quandt, James, ed. Shōhei Imamura, Toronto: Toronto International Film Festival Group, 1997.

Richie, Donald and Anderson, Joseph. The Japanese Film-Art and Industry, New Jersey: Princeton University Press, 1982.

Rothschild, Babette. The Body Remembers, New York: W.W. Norton \& Company, 2000.

Rusell, Catherine. The Cinema of Naruse Mikio, Women and Japanese Modernity, Durham: Duke University Press, 2008.

Ryang, Sonya. Love in Modern Japan, Its Estrangement from Self. Sex and Society, New York: Routledge, 2006.

Saitō, Ayako, "Josei to mōsō-Yoshida Kiju to Okada Mariko," [Women and Fantasy; Yoshida Kiju and Okada Mariko] in Yoshida kiju no zentaizō [The Collection of Yoshida, Kiju's Films] ed. Yomota Inuhiko, Tokyo: Sakuhinsha, 2004. 
---. "Ushinawareta farusu wo motomete," [Reclaiming the Lost Phallus] in Eiga no seijigaku [Film Politics], ed. Hase Masato and Nakamura Hideyuki, Tokyo: Shosha, 2003.

Salih, Sara. ed. The Judith Butler Reader, Malden MA: Blackwell Publishing, 2004.

Sanders, William. Rape and Woman's Identity, London: Sage Publications, 1980.

Satō, Tadao. Currents in Japanese Cinema, Trans. Gregory Barrett, Tokyo: Kodansha Amer. Inc. 1987.

Sharp, Jasper. Behind the Pink Curtain: The Complete History of Japanese Sex Cinema, London: FAB Press, 2008.

Silverman, Kaja. The Acoustic Mirror: The Female Voice in Psychoanalysis and Cinema, Bloomington: Indiana University Press, 1988.

Slaymaker, Douglas. The Body in Postwar Japanese Fiction, London and New York: Routledge Curzon, 2004.

Sobchack, Vivian. Carnal Thoughts: Embodiment and Moving Image, Berkeley: University of California Press, 2004.

---. The Address of the Eye: A Phenomenology of Film Experience (Princeton, NJ: Princeton University Press, 1992).

---. Viewing Positions, Ways of Seeing Film, New Brunswick and New Jersey: Rutgers University Press, 1995.

Stam, Robert, and Shohat, Ella. eds. Unthinking Eurocentrism: Multiculturalism and the Media, London: Routledge, 1994.

Standish, Isolde. Politics, Porn and Protest: Japanese Avant-garde Cinema in the 1960s and 1970s, New York: Continuum International Publishing Group, 2011.

Tessier, Max “ Shōhei Imamura interview," In Shōhei Imamura, ed. James Quandt, Toronto: Toronto International Film Festival Group, 1997, 57-69.

Tsunoda, Takuya. "Toward Human Experience: Hani Susumu on Cinema and Subjectivity," Essay to be published in 2013.

Turim, Maureen. "Feminist Troubles on a Map of Split Subjectivities," In The Films of Öshima Nagisa, Berkeley: University of California Press, 1998, 246-269.

Ueno, Chizuko. Nationalism and Gender, Trans. Beverly Yamamoto, Melbourne: Trans Pacific Press, 2004.

Vlastos, Stephen. ed. Mirrors of Modernity: Invented Traditions of Modern Japan, Berkeley: University of California Press, 1998. 
Wada-Marciano, Mitsuyo. "Ethnicizing the Body And Film. Teshigahara Hiroshi's Woman in the Dunes (1964)," In Japanese Cinema: Texts and Contexts. eds. Alastair Phillips and Julian Stringer. New York: Routledge, 2007, 180-192.

Williams, Linda. Hard Core: Power, Pleasure and the Frenzy of the Visible, Berkeley: University of California Press, 1989.

---. "Film Bodies: Gender, Genre, and Excess," In Film Quarterly, 44. No. 4 (1991): 2-13.

Yomota, Inuhiko, "The Genealogy of the Mother," In Yoshida Kiju-50 Years of AvantGarde Filmmaking, ed. Dick Stegewerns, Oslo: Norwegian Film Institute, 2010.

---. ed. Yoshida Yoshihige no zentaizō [Yoshida Yoshihige's Films], Tokyo: Sakushinsha, 2004.

Yoshida, Kiju. "Hihyō wa motto kakkoku no mono de aru," [Criticism Can Be More Diversified] In Jiko hitei no ronri-sozoryoku ni yoru henshin [The Theory of Self-Negation-Transformation Through Imagination], Tokyo: Sainichi Shobō, 1970.

---. "Kamera wa seiji ni nikuhaku dekiru ka," [Can the Camera Challenge Politics?], In Shinario, Vol. 16, No. 8 (August 1960): 66-67.

---. "My Film Theory-The Logic of Self-Negation" In Yoshida Kiju-50 Years of Avant-Garde Filmmaking, ed. Dick Stegewerns, Oslo: Norwegian Film Institute, 2010.

Young, Iris Marion. On Female Body Experience: 'Throwing Like a Girl' and Other Essays, Oxford: Oxford University Press, 2005.

---. "House and Home: Feminist variations on a Theme," In Gender Struggles: Practical Approaches to Contemporary Feminism, eds. Constance L. Mui and Julien S. Murphy, Lanham, Md.: Rowman and Littlefield. 2002.

Yunomae, Tomoko. "Seibōryoku wo meguru onnna no undō" [Women's Movement Concerning Sexual Violence], In Onnatachi no shisen, ikiruba no feminizumu [Women's Viewpoint, Embodied Feminism] eds. Kanō Yoshiko and Kanō Mikio, Tokyo: Shakai hyōronsha, 1990.

http://wW.bbk.ac.uk/creative/news-events/atg/AT6i\%20abstracts.pdf, Dec.13, 2011.

http://wWw.japansociety.org/resources/content/3/0/1/4/documents/Hatsukoi\%20jigoku hen\%20Nornes.pdf, July 15, 2012.

http://wWW.sarudama.com/japanese_movies/inferno.shtml, August 18, 2012. 
Filmography

Hani Susumu, Nanami, The Inferno of First Love (Nanami, hatsukoi jigokuhen, 1968)

Imamura Shōhei, Insect Woman, (Nippon konchüki, 1963)

Intentions of Murder (Akai satsui, 1964)

The Postwar History of Japan as Told by a Japanese Bar Hostess

(Nippon sengoshi, madamu Onboro no seikatsu, 1970)

Karayuki san, The Making of a Prostitute (Karayuki san, 1975)

Kumai Kei, Sandakan Number 8 (Sandakan hachiban shokan bōkyo, 1974)

Yoshida Kiju, Eros + Massacre (Erosu purasu gyakusatsu, 1969) 